\title{
Geologic Map of Three Sisters Volcanic Cluster, Cascade Range, Oregon
}

By Wes Hildreth, Judy Fierstein, and Andrew T. Calvert

Pamphlet to accompany

Scientific Investigations Map 3186

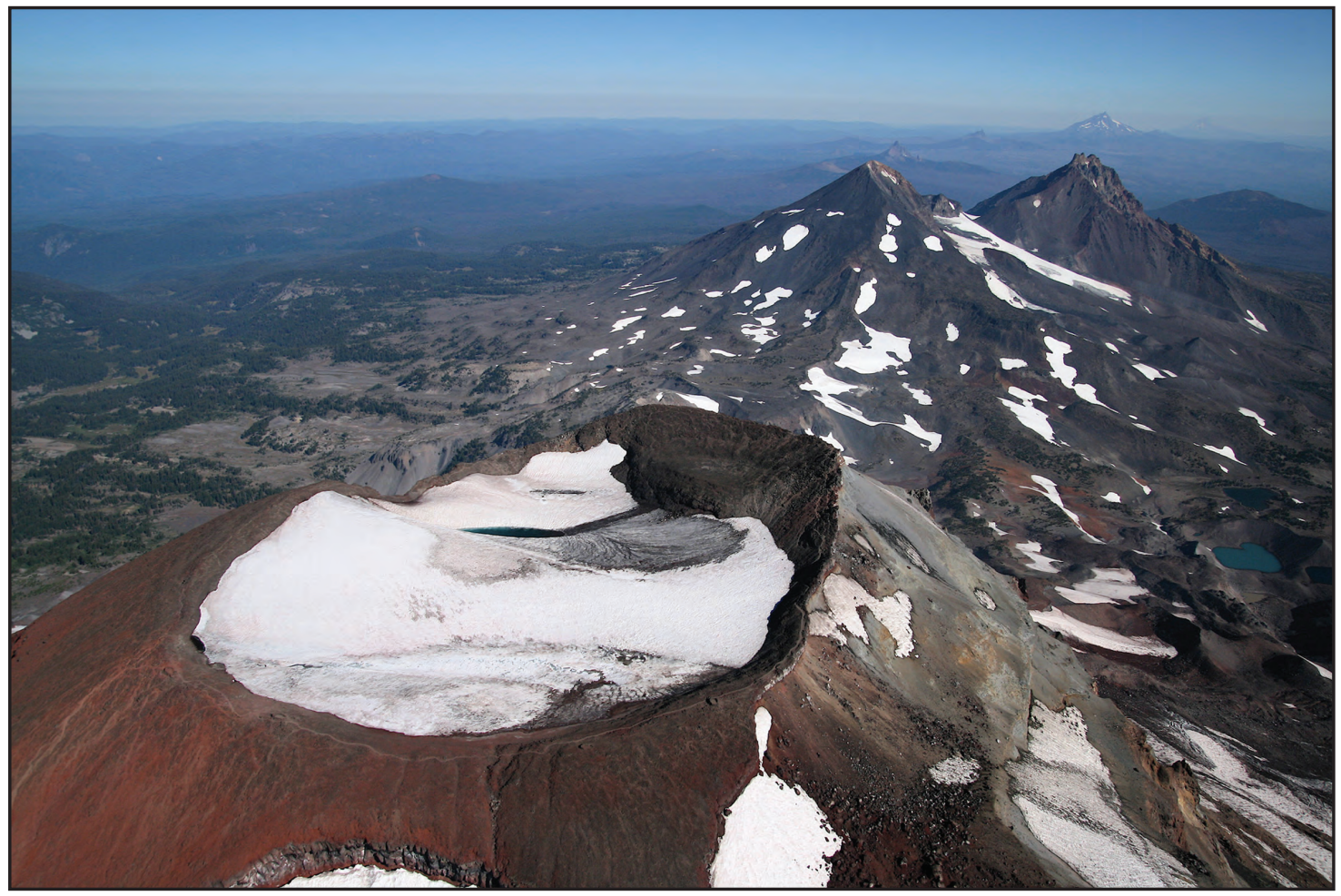

Aerial view northward along glaciated summits of South Sister, Middle Sister, and North Sister volcanoes. Snow and icefilled South Sister crater (rim at 10,358 ft) was created between 30 and $22 \mathrm{ka}$, during most recent of several explosive summit eruptions; thin oxidized agglutinate that mantles current crater rim protects 150 -m-thick pyroclastic sequence that helped fill much larger crater. Middle Sister (10,047 ft) is capped by thick stack of radially dipping, dark-gray, thin mafic lava flows; asymmetrically glaciated, its nearly intact west flank contrasts sharply with its steep east face. Blue lake (near far right edge) is impounded by sharp-crested Neoglacial moraine. North Sister $(10,085 \mathrm{ft})$ is glacially ravaged stratocone that consists of hundreds of thin rubbly lava flows and intercalated falls that dip radially and steeply; remnants of two thick lava flows cap summit. Broad mafic shield beyond North Sister is Black Crater; distant peak on horizon is Mount Jefferson; and Mount Hood is in dim distance. Photograph by John Scurlock, 2007. 
This page intentionally left blank 


\section{Contents}

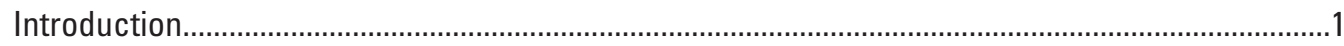

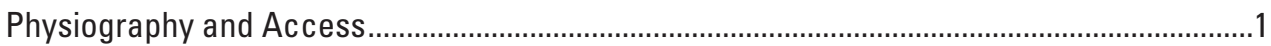

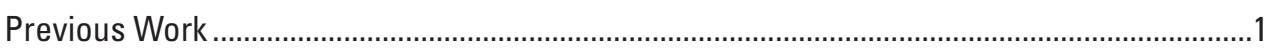

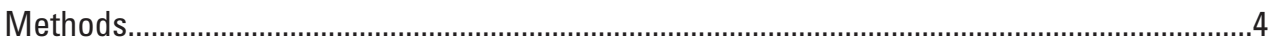

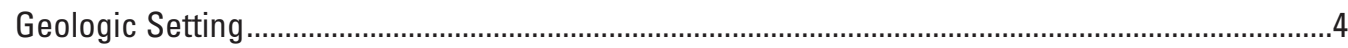

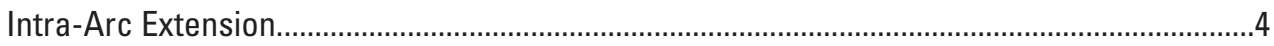

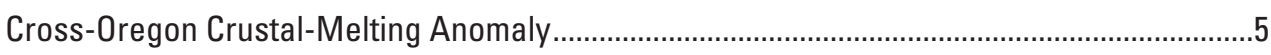

Local Basement Rocks...................................................................................................

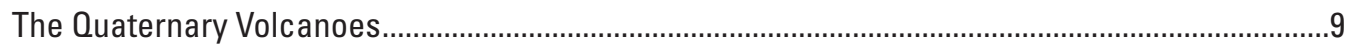

The Mafic Periphery .....................................................................................................

Broken Top and the Tumalo Volcanic Field.........................................................................10

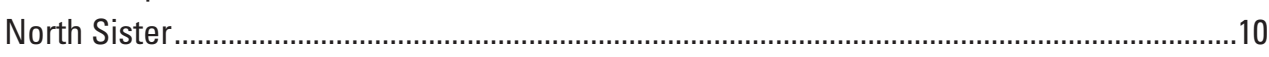

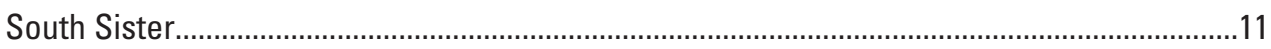

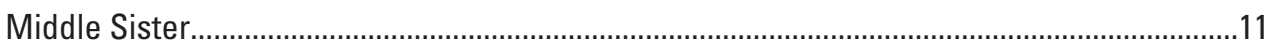

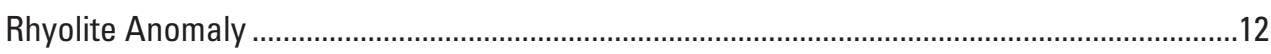

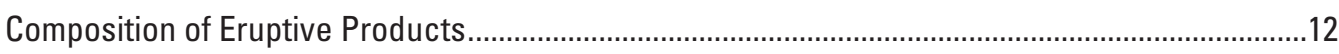

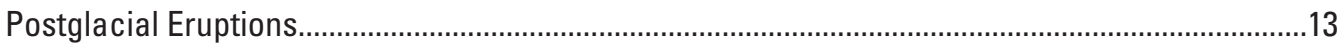

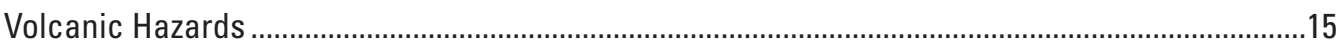

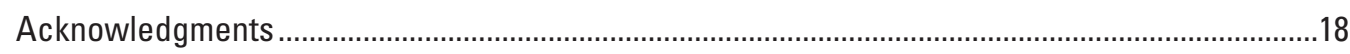

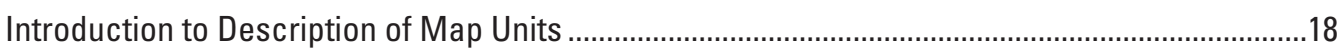

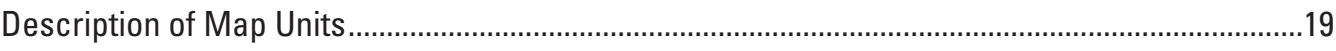

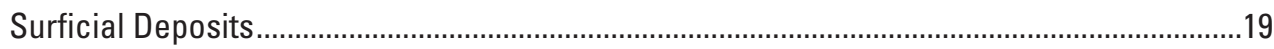

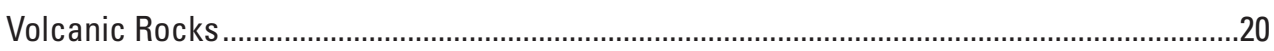

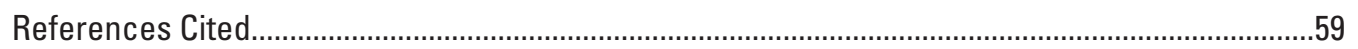

\section{Figures}

1. Regional location map of western Oregon, showing principal physiographic provinces, selected rivers and cities, and major Quaternary volcanic edifices of Cascade Range, including Three Sisters volcanic cluster.

2. Map of Three Sisters region, showing locations of many geographic features mentioned

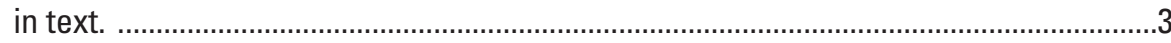

3. Tectonic setting of Quaternary Cascade arc. .................................................................6

4. Rhyolite vents of Three Sisters and rear-arc Newberry caldera region. .............................8

5. Chemical variation diagrams for more than 730 samples of Quaternary eruptive products of Three Sisters volcanic cluster................................................................................. 14

6. Plots showing $\mathrm{Zr}, \mathrm{MgO}, \mathrm{TiO}_{2} \mathrm{Sr}_{2} \mathrm{FeO}^{*}$, and $\mathrm{Al}_{2} \mathrm{O}_{3}$ versus $\mathrm{SiO}_{2}$ contents for eruptive products of Three Sisters volcanic cluster. ...............................................................16

\section{Tables}

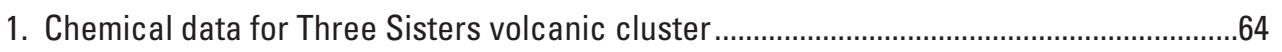

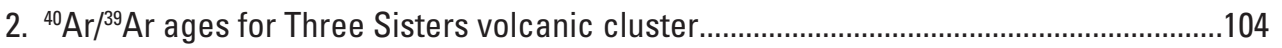

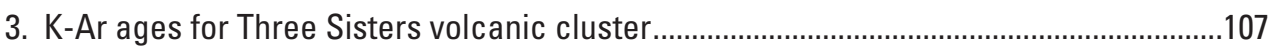

\section{Sheets}

1. Geologic Map

2. Correlation of Map Units and List of Map Units 
This page intentionally left blank 


\section{Introduction}

The cluster of glaciated stratovolcanoes called the Three Sisters forms a spectacular 20-km-long reach along the crest of the Cascade Range in Oregon, $35 \mathrm{~km}$ west of Bend and 100 $\mathrm{km}$ east of Eugene (fig. 1). As observed by trailblazing volcanologist, Howel Williams (1944), "For magnificence of glacial scenery, for wealth of recent lavas, and for graphic examples of dissected volcanoes, no part of this range surpasses the area embracing the Sisters and McKenzie Pass." The area we have now mapped in detail consists exclusively of Quaternary volcanic rocks and derivative surficial deposits. Although most of the area has been modified by glaciation, the volcanoes are young enough that the landforms remain largely constructional. Locations of many of the geographic features mentioned in this report are shown in figures 1 and 2 .

Scientific and journalistic interest in the Three Sisters volcanic cluster was aroused a few years ago when ongoing uplift centered about $5 \mathrm{~km}$ west of South Sister was identified, first recognized by satellite imagery (interferometric synthetic aperture radar, InSAR) in 2001 (Wicks and others, 2002). Subsequent geodetic measurements and continuing InSAR analysis confirmed 3 to $4 \mathrm{~cm} / \mathrm{yr}$ uplift during the interval from 1997 to 2004; the uplift has been modelled as inflation thought to be caused by an intracrustal intrusion (Dzurisin and others, 2006, 2009), largely aseismic and plausibly involving mafic magma like that which was last erupted $11 \mathrm{~km}$ to the north about 1,500 years ago.

Twelve of the 145 eruptive units described below are postglacial, younger than the deglaciation that was underway by about $17 \mathrm{ka}$. The most recent eruptions were of rhyolite near South Sister, about 2,000 years ago, and of mafic magma near McKenzie Pass, about 1,500 years ago. Despite the recency of eruptive activity, no fumaroles or hot springs are recognized in the area. West of South Sister, however, several springs (some of which are geochemically anomalous) that have orifice temperatures in the range of $2^{\circ}$ to $12^{\circ} \mathrm{C}$ are present (Evans and others, 2004).

The three eponymous stratocones, though contiguous and conventionally lumped sororally, could hardly display less family resemblance. North Sister is a monotonously mafic edifice at least as old as $120 \mathrm{ka}$; Middle Sister, an andesitebasalt-dacite cone built between 48 and $14 \mathrm{ka}$; and South Sister, a bimodal rhyolitic-intermediate edifice that was constructed between $50 \mathrm{ka}$ and $2 \mathrm{ka}$. For each of the three, eruptive volume is likely to have been in the range of 15 to $25 \mathrm{~km}^{3}$, but such estimates are fairly uncertain, owing to glacial erosion.

\section{Physiography and Access}

Nearly all of the map area lies within the Three Sisters Wilderness, which is roadless, is free of buildings and shelters, and is protected by the Deschutes and Willamette National Forests. Seasonal access on foot is nonetheless simple, as numerous trails (many maintained and others informal) crisscross the wilderness from trailheads near the McKenzie Pass Highway (Hwy 242) to the north (fig. 2), the Cascade Lakes
Highway (Hwy 46) to the south, and several Forest Service roads to the east. Most trails are accessible from July through October, but for the rest of the year, owing to heavy snowfall, few people (other than cross-country skiers) enter the wilderness. Average annual precipitation on the crest of the Cascade Range, measured at Santiam Pass (elevation 4,817 ft [1,468 $\mathrm{m}$ ], about $28 \mathrm{~km}$ north of North Sister), is $217 \mathrm{~cm}$ (85.3 in), and average snowfall is $1,145 \mathrm{~cm}$ (451 in) [Western Regional Climate Center (http://www.wrcc.dri.edu/index.html)]. Only 8 percent of the average annual precipitation (and very little snow) falls there in the July-to-September quarter of the year. Precipitation falls off sharply east of the crest, to annual averages of about $34 \mathrm{~cm}$ at Sisters and $30 \mathrm{~cm}$ at Bend (fig. 1). Like the Sierra Nevada of California, the Three Sisters is a "gentle wilderness:" its summer climate is usually moderate, and its relief, distances, and wildlife hazards are modest, yet it remains spectacular and largely unspoiled.

The three principal volcanoes are similar in elevation: North Sister, 10,085 ft (3,074 m); Middle Sister, 10,047 ft $(3,062 \mathrm{~m})$; and South Sister, 10,358 ft $(3,157 \mathrm{~m})$. Their surrounding lava-flow aprons descend southward to about 5,440 $\mathrm{ft}(1,658 \mathrm{~m})$ near Sparks Lake, northeastward to below 4,400 ft $(1,340 \mathrm{~m})$ at Trout Creek Swamp and along Whychus Creek (on topographic maps, shown as "Squaw Creek"), and westward to about 5,000 ft (1,525 m) near Indian Holes and as low as 3,500 $\mathrm{ft}(1,065 \mathrm{~m})$ at Linton Lake. To its southeast and northwest, however, lavas of South Sister were buttressed by older edifices and, thus, bank as high as 7,000 ft $(2,135 \mathrm{~m})$ against Broken Top and up to $6,100 \mathrm{ft}(1,860 \mathrm{~m})$ against The Husband. Middle Sister, although lowest of the three main summits, nevertheless has the greatest relief of about $6,550 \mathrm{ft}(2,000 \mathrm{~m})$ because its western apron extends all the way down to Linton Lake.

The glacial ice that formerly mantled virtually the entire mapped area has diminished to 16 small glaciers, largely confined to cirques on the Three Sisters edifices, as shown on 1997 USGS topographic maps, which are based on aerial photographs taken as recently as 1982 . Of the seven named glaciers on South Sister, however, Skinner and Carver Glaciers have since shrunk into stagnant snowfields, as has Irving Glacier on Middle Sister. Thayer and Villard Glaciers on North Sister and Renfrew Glacier on Middle Sister are small and close to extinction. As the climate changes, more and more rubble is exposed at the expense of ice.

\section{Previous Work}

The first geological overview of the Three Sisters region was presented in a book by Hodge (1925), which (although volcanologically wanting) remains worth reading for its historical, geographic, and natural history contributions. A volcanological reconnaissance by Williams (1944), which was based on only six weeks fieldwork, nicely established the main outlines of the Three Sisters and of several peripheral mafic volcanoes. Lacking chemical data, however, Williams called all the rhyolite lavas "dacite" (although he speculated that some would eventually be proven rhyolitic), and he also reckoned the ages of all the glaciated edifices to be far greater than now established 


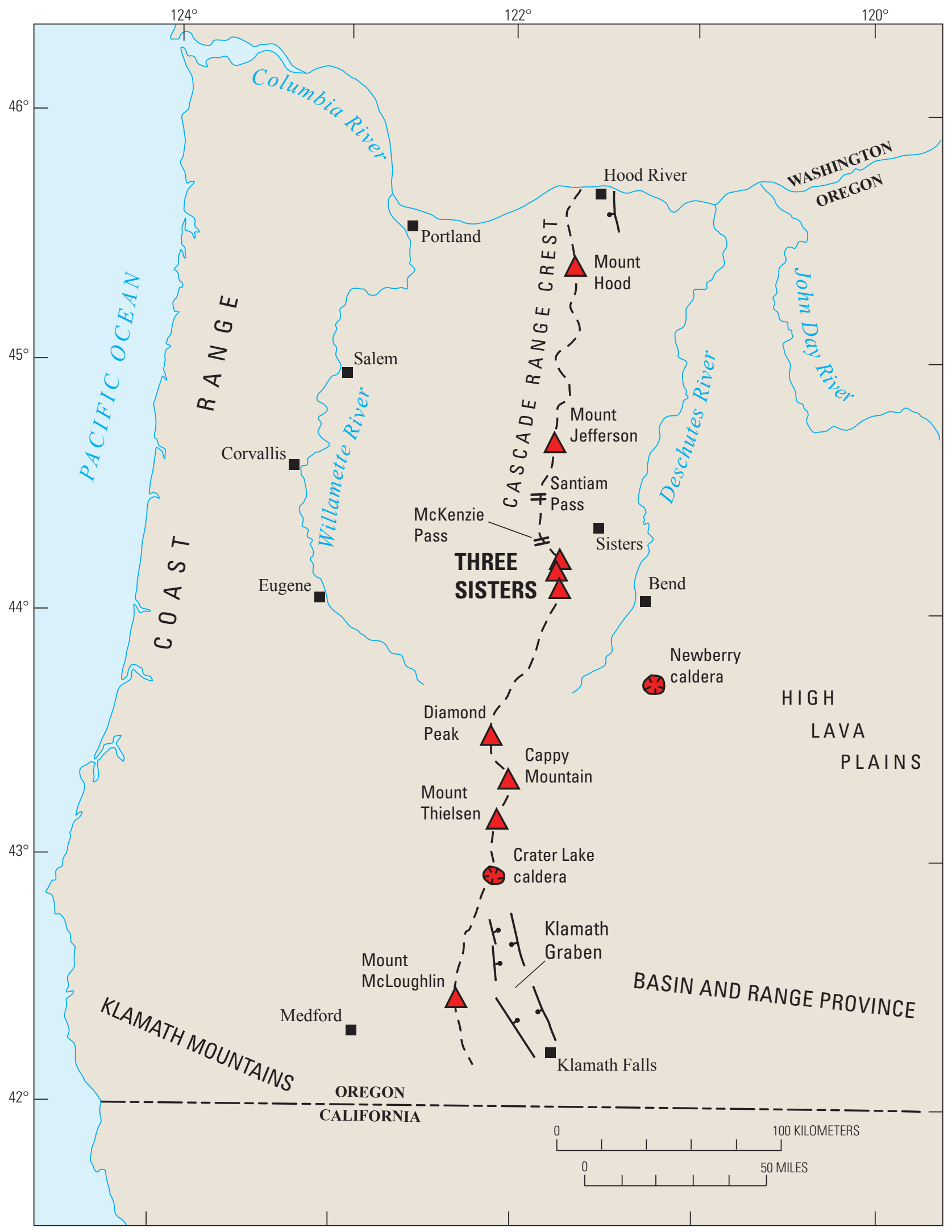

Figure 1. Regional location map of western Oregon, showing principal physiographic provinces, selected rivers and cities, and major Quaternary volcanic edifices of Cascade Range, including Three Sisters volcanic cluster. Solid black lines indicate main faults; ball and bar indicates downthrown side of normal faults. Dashed line through Three Sisters and nearby mountains and passes shows trace of Cascade Range crest, which is main drainage divide and approximate axis of Quaternary volcanic chain. 


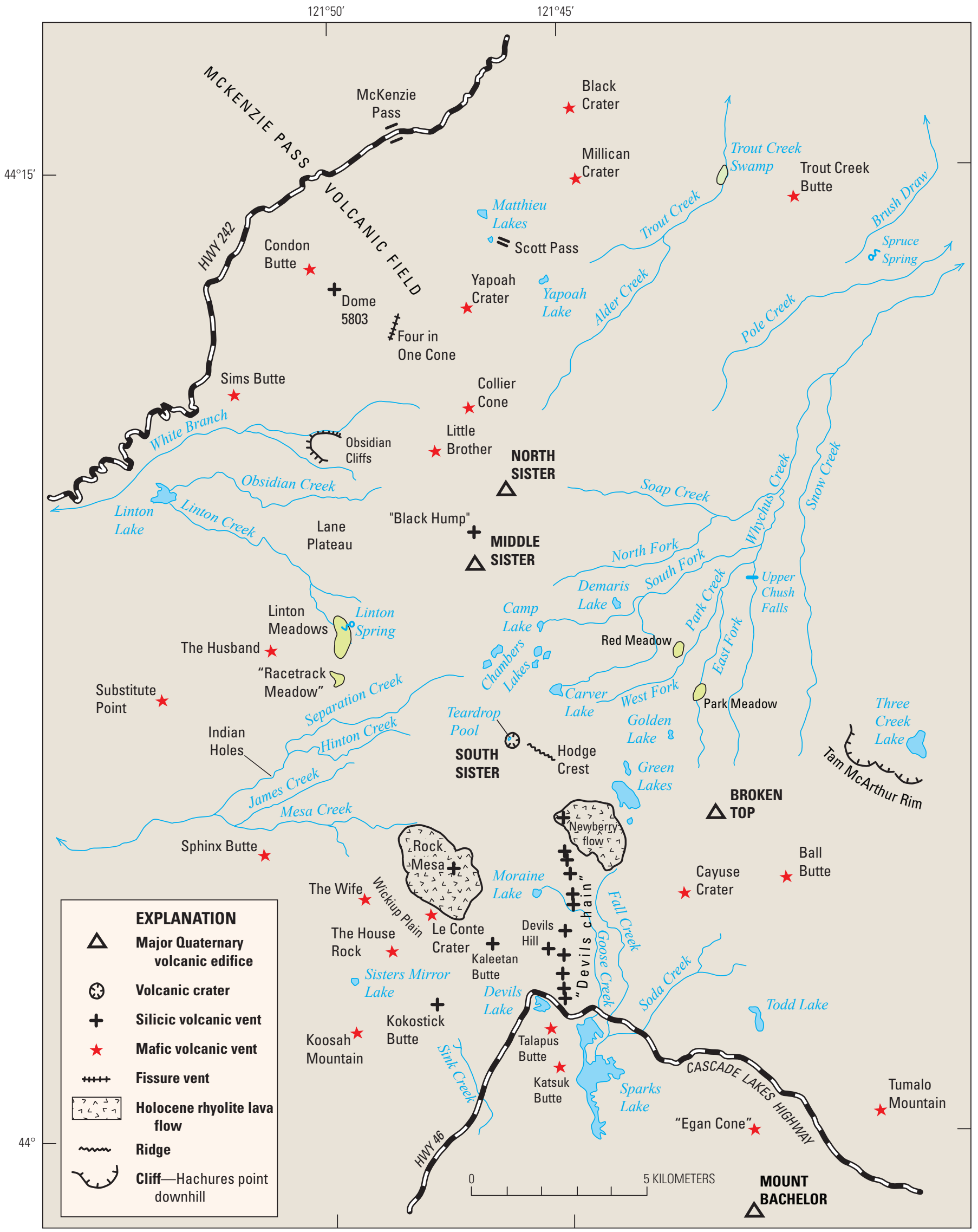

Figure 2. Map of Three Sisters region, showing locations of many geographic features mentioned in text. 
by modern geochronology. Progressively more complete reconnaissance mapping and compilations subsequently were produced by Taylor and others (1987) and Sherrod and others (2004). Williams (1957) also published a reconnaissance geologic map of the entire Cascade Range of central Oregon from Crater Lake to Mount Jefferson (fig. 1). More detailed geologic maps of two quadrangles that overlap the eastern part of our study area were published by Taylor $(1978,1987)$. The most detailed geologic investigations here were by Scott (1987), on late Holocene rhyolites peripheral to South Sister, and a map by Scott and Gardner (1992) that covers the southeast flank of South Sister and the entire Mount Bachelor chain farther south. A geochemical study of mafic lavas in the region that includes the Three Sisters was published by Hughes and Taylor (1986) and Hughes (1990). Topical thesis studies emphasizing chemistry and petrography of particular areas were completed by Wozniak (1982), Clark (1983), Hill (1991), Webster (1992), Schick (1994), Gardner (1994), and Schmidt (2005). Mercer and Johnston (2008) and Schmidt and Grunder (2009) investigated the eruptive history and petrology of North Sister. A summary of the Sisters reach of the Quaternary Cascade arc - a 90-km-long subsegment centered on, but extending well north and south of, our Three Sisters map area-was included in an arc-wide overview by Hildreth (2007).

\section{Methods}

We spent about one month each summer from 2000 to 2009 mapping the volcanic field on foot, generally late in the season when snowmelt was most advanced. About 200 days were devoted to productive fieldwork, excluding stormy days, rest days, and travel to and from our California office. Because most of the area is glaciated and till strewn, aerial photographs were of only minor utility, and our detailed mapping was done directly on USGS 1:24,000-scale topographic quadrangle maps (South Sister, North Sister, Linton Lake, Trout Creek Butte, and Broken Top). A hand-held GPS device commonly was useful in the woods. Our goal was to study in detail the Three Sisters and the eruptive products of contemporaneous vents on their aprons. Accordingly, no effort was made to complete the quadrangles nor to undertake detailed mapping of the older (mostly middle Pleistocene) mafic centers that surround the Three Sisters cluster. The Three Sisters map area is bordered on its northwest side by the postglacial McKenzie Pass volcanic field (Taylor, 1968; Sherrod and others, 2004), which extends $25 \mathrm{~km}$ farther northwestward; we chose to show its southernmost component (lava flows from Collier Cone) and its easternmost component (the eastern lava flow from Yapoah Crater) as convenient margins for the Three Sisters map area.

One or several thin sections for each of the 145 volcanic units mapped were examined microscopically, and the observations are summarized in the unit descriptions. Most samples were analyzed chemically, as described and listed in table 1.

For a large fraction of the 130-odd pre-Holocene units herein defined, radioisotopic ages were determined in the U.S. Geological Survey geochronology laboratory in Menlo Park, California (supervised by A.T. Calvert). Most samples in this study were dated using ${ }^{40} \mathrm{Ar} /{ }^{39} \mathrm{Ar}$ incremental-heating techniques, following methods described in Calvert and Lanphere (2006) and Hildreth and others (2007), and the results are listed in table 2. Samples were irradiated at the U.S. Geological Survey reactor in Denver, Colorado, using 27.87-Ma Taylor Creek sanidine as a neutron-flux monitor. In table 2, weightedmean plateau ages, isotope-correlation (isochron) ages, and total-gas ages are reported, and our interpreted eruption ages are highlighted in bold font. Plateau ages generally are interpreted as the most reliable if the ${ }^{40} \mathrm{Ar} /{ }^{36} \mathrm{Ar}$ intercept is within analytical error of atmospheric argon $\left({ }^{40} \mathrm{Ar} /{ }^{36} \mathrm{Ar}=295.5\right)$. Isochron ages are interpreted as the most reliable if the ${ }^{40} \mathrm{Ar} /{ }^{36} \mathrm{Ar}$ intercept is outside analytical error of atmospheric argon. Total-gas ages are interpreted as the most reliable on fine-textured samples that show evidence for significant ${ }^{39} \mathrm{Ar}$ recoil. In several cases, we tested ${ }^{39} \mathrm{Ar}$-recoil effects by conducting K-Ar analyses on the same rocks (table 3), following methods described in Hildreth and Lanphere (1994). Results from K-Ar determinations were concordant with the ${ }^{40} \mathrm{Ar} /{ }^{39} \mathrm{Ar}$ results, and, in one sample (TS94, unit rkb), K-Ar analysis yielded a reliable age that we were unable to obtain with ${ }^{40} \mathrm{Ar} /{ }^{39} \mathrm{Ar}$ methods.

\section{Geologic Setting}

For a convergent-margin volcanic belt, the density of Quaternary volcanoes in the Cascade Range of Oregon (commonly called the Oregon Cascades) is extraordinary (about 1,050 vents). The only comparably extensive areas that have such dense concentrations of Quaternary-arc volcanoes are in southern Washington, northern California, Michoacán (Mexico), and a few short reaches of the Chilean Andes (Hildreth, 2007).

No well-defined volcanic front exists in Oregon (Hildreth, 2007). The crest of the Cascade Range, site of the Three Sisters, lies about $270 \mathrm{~km}$ east of the submarine deformation front that marks the site of a sediment-filled trench. The crust beneath the Cascade crest in Oregon is thought to be about $44 \mathrm{~km}$ thick (Leaver and others, 1984; Mooney and Weaver, 1989). The subducting slab beneath Oregon is virtually aseismic, and, because tomographic models for its dip and depth beneath the Oregon arc and forearc vary widely (Michaelson and Weaver, 1986; Rasmussen and Humphreys, 1988; Harris and others, 1991; Bostock and others, 2002; McCrory and others, 2004), its configuration remains uncertain.

\section{Intra-Arc Extension}

The plate-convergence rate at the latitude of the central Oregon Cascades is only about $3.5 \mathrm{~cm} / \mathrm{yr}$, increasing slightly northward (McCaffrey and others, 2007). The azimuth at which the Juan de Fuca plate underthrusts the Oregon plate margin is about N. $45^{\circ} \mathrm{E}$., oblique to the north-trending plate boundary.

In addition to the basal traction that probably is contributed by the oblique plate convergence, tectonic deformation of Cascadia and adjacent areas is driven fundamentally by the dextral shear between the Pacific and North American plates (Atwater, 1970) and by the extension promoted by buoyant 
mantle beneath the western Basin and Range Province (Jones and others, 1996). Opposite the Cascade arc, most of the relative motion between the two megaplates is accommodated by spreading on the Juan de Fuca Ridge and subduction beneath Cascadia, but some 25 percent of the relative motion is distributed far inboard as block rotations and translations (Pezzopane and Weldon, 1993; Walcott, 1993; Wells and others, 1998; McCaffrey and others, 2007).

In response to the dextral shear couple, and in concert both with northwestward motion of the nearly rigid Sierra NevadaGreat Valley microplate (Dixon and others, 2000; Hammond and Thatcher, 2004) and with Basin and Range extension inboard (fig. 3), the Oregon forearc has undergone clockwise rotation since at least the middle Miocene (Wells and Heller, 1988; Wells, 1990; Wells and others, 1998). Along its trailing margin, rotation of the forearc block apparently contributes to the intra-arc and rear-arc east-west extension significant along the Oregon Cascades, from the Klamath Graben to the Columbia River (figs. 1, 3). On the decadal timescale of GPS measurements, however, intra-arc extension here is currently limited to about $1 \mathrm{~mm} / \mathrm{yr}$ or less (McCaffrey and others, 2007). Oblique subduction of the Juan de Fuca plate probably also contributes by basal traction to northward motion of the Cascadia forearc. Northwestward translation of the Sierra Nevada-Great Valley microplate involves a broad dextral inboard shear zone (Walker Lane) that extends from southern Nevada to northeastern California, where the northwest-trending strike-slip belt merges diffusely into the array of north-striking normal faults that reach northward through the Klamath Graben, Mount Mazama, and the Cascade Range of central Oregon (fig. 3). The transition from predominantly dextral shear in California to block rotation in Oregon lies between the Lassen and Shasta segments of the arc, coinciding with the transition offshore from a strike-slip to a subducting plate boundary (fig. 3).

Farther north, the Brothers Fault Zone (fig. 3), a belt of weaker northwest-trending dextral shear, provides a diffuse northern margin for the Basin and Range extended region (Lawrence, 1976). The Brothers Fault Zone likewise terminates diffusely against the Cascade arc, first stepping left (west) to form the northwest-trending Sisters (Tumalo) Fault Zone, which, in turn, merges with the north-striking High Cascades Graben (fig. 3; see also Taylor, 1981, 1990; Smith and Taylor, 1983; Smith and others, 1987; Sherrod and others, 2004). Elements of this intra-arc belt of modest east-west extension, structurally active at least since $5 \mathrm{Ma}$, may or may not be continuous along the Cascade Range axis from Green Ridge $\left(44.5^{\circ} \mathrm{N}\right.$.) northward through the Mount Jefferson reach to join the Hood River Fault (fig. 3) near the Columbia River (Walker and MacLeod, 1991; Conrey and others, 1997, 2002), where discernible extension apparently peters out.

Although the Juan de Fuca plate subducts northeastward beneath the North American plate, the maximum principal horizontal-stress direction in the upper plate is margin parallel, not in the convergence direction (Spence, 1989; Zoback, 1992). Presumably owing to the combination of oblique convergence and the northward push of the Sierra Nevada-Great Valley microplate through the Klamath Block (fig. 3), the direction of compression is north-south in Washington and Oregon and as far south as Mount Shasta, within the arc, forearc, and parts of the rear arc such as the Yakima Foldbelt. This stress orientation is reflected in north-south vent alignments from Mount Shasta to Mount Adams, but nowhere in the Cascade Range are vent alignments more conspicuous than here in the reach containing the Three Sisters, where lines of mafic volcanoes (and even a chain of Holocene rhyolite vents) form north-striking arrays (Bacon, 1985; Hughes and Taylor, 1986; Scott, 1987; Scott and Gardner, 1992). Without specific evidence, however, such vent alignments should not be assumed to have been supplied contemporaneously by a common dike system or to reflect a fissure-fed eruption. Many such alignments include varied magmas that erupted thousands of years apart, and parallelism of the dikes that presumably underlie them results from the enduring stress field, not necessarily from a common magma reservoir.

Differential extension and block rotation of the lithosphere may well play a more important role than subduction geometry in controlling segmentation of the volcanic belt, in defining its several distinguishable reaches in Oregon, and in promoting its exceptional width in California and southern Washington (Hildreth, 2007). The Cascade arc has been a well-defined, continuous belt since the Eocene, but dextral shear, block rotations, and Basin and Range extension were not imposed on the arc until the middle Miocene. Had none of these external tectonic processes been superimposed on the Cascade Range, a Cascade arc would, nonetheless, still exist today, owing to the slab-derived contribution to mantle-wedge melt production. In all likelihood, however, there would be no rear-arc center at Newberry Volcano, none of the $\mathrm{H}_{2} \mathrm{O}$-poor, low-K, high-alumina olivine tholeiite so abundant in central Oregon, and no true rhyolite in the Three Sisters reach of the arc.

\section{Cross-Oregon Crustal-Melting Anomaly}

The Three Sisters lie at the leading end of a crustal-melting anomaly that has propagated across Oregon (fig. 3) since the middle Miocene (MacLeod and others, 1975; Jordan and others, 2004). The anomaly manifested in the eruption of numerous units of true rhyolite $\left(72-77 \% \mathrm{SiO}_{2}\right)$, which is rare elsewhere along the Cascade arc (although common at rear-arc centers and in the extensional continental interior). Initiation of rhyolitic volcanism started in southeastern Oregon, advancing across Harney Basin by $9 \mathrm{Ma}$ and Fort Rock Valley by $5 \mathrm{Ma}$. After this the rate of westward propagation slowed markedly (Jordan and others, 2004), approaching the later site of Newberry Volcano in the early Quaternary. Several middle and late Pleistocene rhyolites subsequently erupted near Newberry Volcano and in the Tumalo volcanic field (east of Broken Top; Hildreth, 2007), followed by rhyolites still farther northwest that range in age from $50 \mathrm{ka}$ to $2 \mathrm{ka}$ at Middle Sister and South Sister (fig. 4). Progression of the Oregon melting anomaly is sometimes said to mirror the comparable northeastward propagation of rhyolite initiation along the Snake River Plain as far as Yellowstone over the same time interval (Christiansen and McKee, 1978; Christiansen and others, 2002; Jordan and others, 2004), but the volume of 


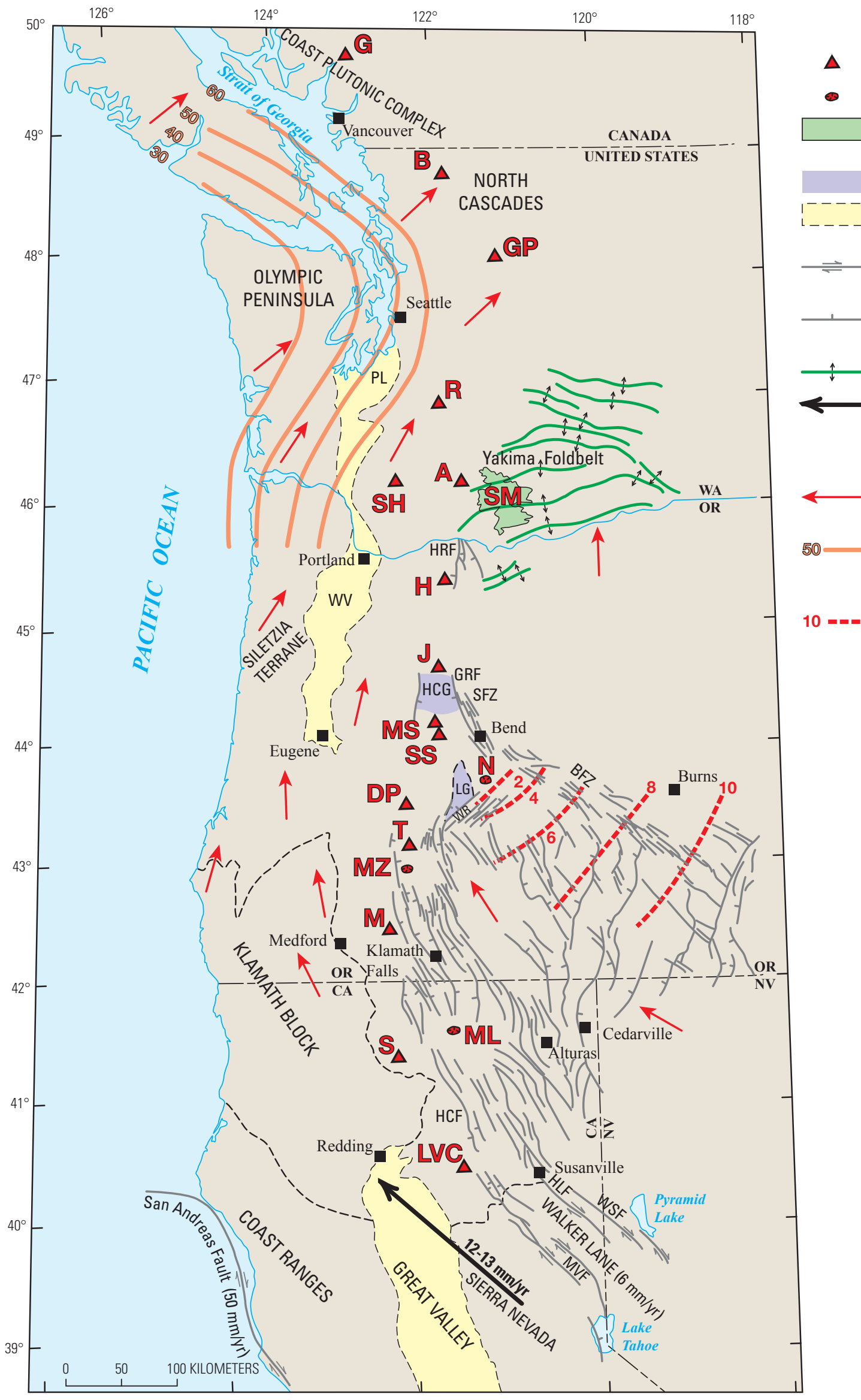

EXPLANATION

Selected large volcano

Simcoe Mountains volcanic field

Area of deep graben fill

Approximate outline of major valley

Fault-Arrows show relative movement

Normal fault-Tick on downthrown side

Anticlinal axis

Direction and rate of movement of Sierra Nevada-Great Valley microplate

Direction of Cascadia rotation

Structure contour, showing depth (in km) of subducting slab

Isochron, showing age (in Ma) of inception of rhyolitic volcanism 
rhyolite erupted along the Oregon trend is only about 1 percent of that along the Snake River Plain. Along both trends, eruption of considerable amounts of basalt and some rhyolite continued long after passage of the rhyolite-initiating front.

Because true rhyolites are so rare elsewhere within the Quaternary Cascade arc, as opposed to the rhyodacites (68-72\% $\mathrm{SiO}_{2}$ ) so abundant at Mount Jefferson and Crater Lake, it is likely that the rhyolite-generating crustal-melting anomaly beneath the Tumalo and Three Sisters areas is principally attributable to whatever combination of mantle flow and decompression has been responsible for the 16-m.y.-long westward propagation of intracrustal melting and rhyolitic volcanism across the High Lava Plains. Now that the leading edge has penetrated the Cascade arc, rhyolite production may recently be enhanced in the Sisters reach by the presence of preheated arc crust.

\section{Local Basement Rocks}

Although crystalline basement rocks of Mesozoic and greater age underlie the northern and southern parts of the Cascade arc, from near Mount Rainier southward $500 \mathrm{~km}$ to the Oregon-California border, basement rocks are wholly concealed (in the so-called "Columbia Embayment") beneath Cascade-arc rocks of Eocene to Holocene age. A large window of basement rocks $20 \mathrm{~km}$ southeast of Mount Rainier (Miller, 1989) has age and lithologic affinities to the thrust sheets and mélange belts of both the Klamath Mountains and the Northwest Cascades. Consisting of tectonic slices and accretionary mélange of submarine-fan deposits, hemipelagic seafloor deposits, pillowed MORB greenstones, and tonalitic and mafic metaigneous K-poor arc rocks, all of Mesozoic age, the assemblage may represent the thick crust concealed beneath much of the "embayment." Although it has been speculated that Mesozoic or Tertiary seafloor may underlie the "embayment," a thick stack of varied accretionary rocks, which were thrust or underplated inboard and translated dextrally northward along the Mesozoic continental margin, is more consonant with the 44-km-thick sub-arc crust and with the absence of any along-arc discontinuity in the seismic-velocity structure along a refraction profile up the axis of the Oregon Cascades (Leaver and others, 1984).

Older rocks that are exposed adjacent to the Quaternary volcanic belt in central Oregon include the following three suites:

Suite 1-Cascade-arc assemblages of late Eocene to late Miocene age form a 70-km-wide terrain that crops out from the Willamette Valley to the western margin of the Quaternary volcanic belt and dips gently eastward beneath it. The maturely dissected terrain consists of varied sequences of tuffs, lavas, and lahar deposits, roughly $5 \mathrm{~km}$ thick, that are deeply eroded and regionally affected by low-grade alteration, although only modestly deformed (Peck and others, 1964; Sherrod and Smith, 2000). Pyroclastic and derivative sedimentary rocks dominate over lavas in the lower three-quarters of the pile, but andesitic

Figure 3. Tectonic setting of Quaternary Cascade arc. For complete Quaternary vent distribution and offshore plate system, see Hildreth (2007). Abbreviations for volcanoes, calderas, and volcanic fields: A, Mount Adams; B, Mount Baker; DP, Diamond Peak; G, Mount Garibaldi; GP, Glacier Peak; H, Mount Hood; J, Mount Jefferson; LVC, Lassen volcanic center; M, Mount McLoughlin; ML, Medicine Lake volcano; MS, Middle Sister; MZ, Mount Mazama (Crater Lake); N, Newberry Volcano; R, Mount Rainier; S, Mount Shasta; SH, Mount St. Helens; SM, Simcoe Mountains; SS, South Sister; T, Mount Thielsen. Abbreviations for faults, as well as for geomorphic and geographic features: BFZ, Brothers Fault Zone; GRF, Green Ridge Fault; HCF, Hat Creek Fault; HCG, High Cascades Graben; HLF, Honey Lake Fault; HRF, Hood River Fault; LG, La Pine Graben; MVF, Mohawk Valley Fault; PL, Puget Lowland; SFZ, Sisters (Tumalo) Fault Zone; WR, Walker Rim; WSF, Warm Springs Fault; WV, Willamette Valley. Worth noting are the following features: (1) Extensional region has expanded westward since late Miocene to overlap subduction-induced magmatic arc in California and Oregon. (2) Plate-boundary shear traction principally drives northwestward translation of rigid Sierra Nevada-Great Valley microplate, accounting for about 25 percent of relative motion between Pacific plate and stable North America plate (Dixon and others, 2000), most of which takes place along San Andreas Fault. Dextral shear (6 mm/yr) on Walker Lane (belt of rheologically weak lithosphere) accounts for about half of microplate translation and diffusely merges northwest into region of intra-arc normal faulting. (3) Microplate compression through Klamath Block helps (along with oblique plate convergence) to drive northward translation and clockwise rotation of Oregon forearc, contributing to intra-arc extension along its trailing edge. Oregon forearc block dominantly consists of 30-km-thick accreted oceanic crust of Siletzia terrane; its northward motion compresses accretionary Washington forearc against Canadian batholithic buttress (Wells and others, 1998). North Cascades and Coast Plutonic Complex predominantly consist of crystalline basement terranes of Mesozoic and older metamorphic and plutonic rocks. Directions of Cascadia rotation generalized from hundreds of GPS sites referenced to stable North America (McCaffrey and others, 2007). (4) Seaward-concave plate margin promotes slab arch, axis of which plunges toward $48^{\circ} \mathrm{N}$.; slab depth inferred from seismicity and tomography by Crosson and Owens (1987). (5) Proximal forearc depression, 50 to 100 km seaward of active arc, is occupied by Strait of Georgia, Puget Lowland, and Willamette Valley and may reflect densification of slab at eclogite transition; its absence south of Eugene may reflect upper-plate deformation by northward-translating Klamath Block. (6) Formation of Yakima Foldbelt, which principally deforms lavas of the Columbia River Basalt Group, began about 15 Ma during their main eruptive interval and continues today; Mount Adams, Mount Hood, and Simcoe Mountains volcanic field overlie Yakima folds. (7) In central Oregon, isochrons depict westward progression of inception of rhyolitic volcanism across High Lava Plains (MacLeod and others, 1975; Jordan and others, 2004); in the Quaternary, eruptions of true rhyolite (rare elsewhere in Cascade arc) have further advanced through Newberry Volcano and as far northwest as South and Middle Sisters (see fig. 4). 


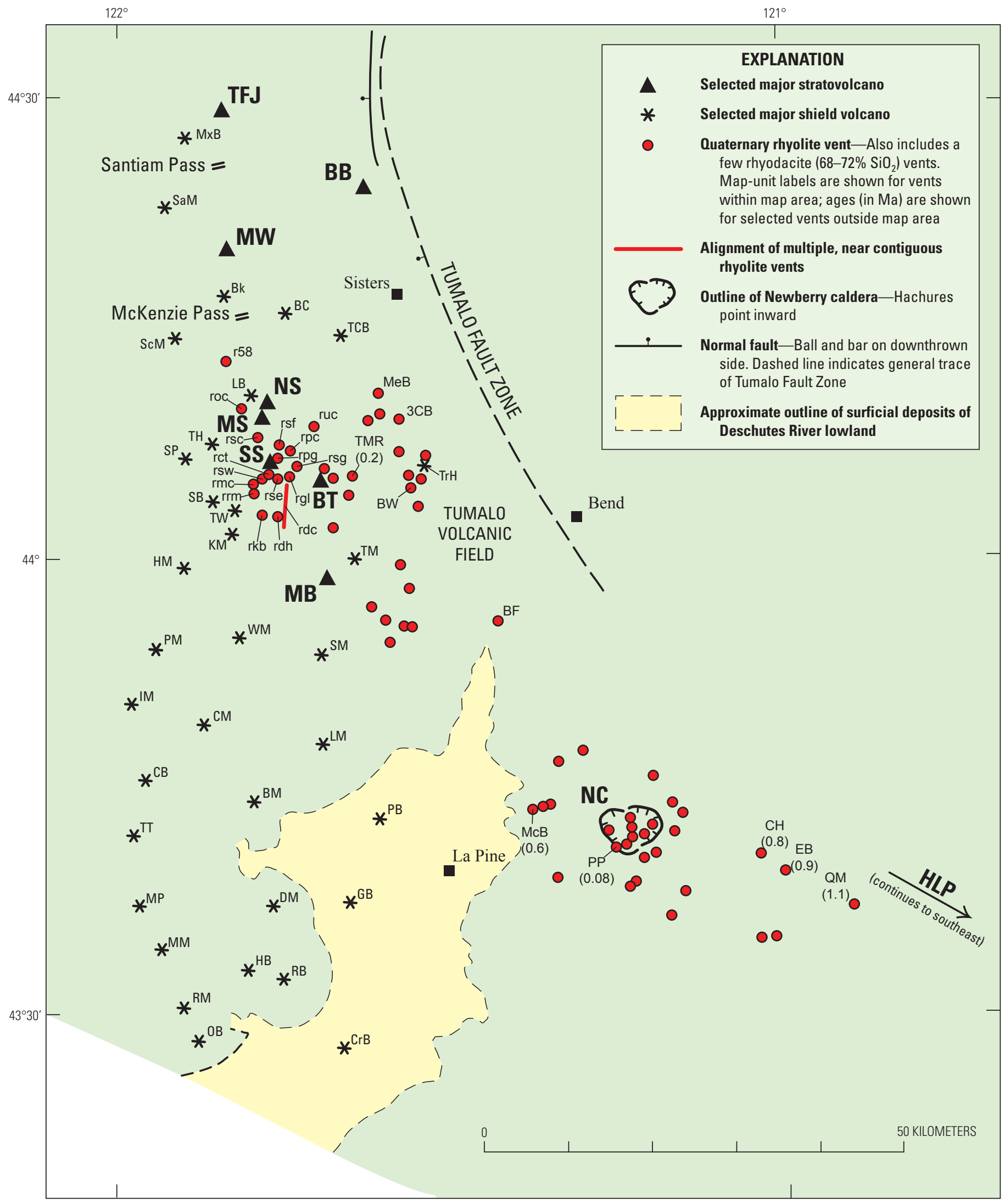


(and lesser amounts of basaltic and silicic) lavas dominate in the top kilometer or so. The western Cascade-arc suite is weakly folded here (characterized by dips typically $5^{\circ}$ to $15^{\circ}$ ), although it is affected by somewhat stronger folding and faulting farther north. Many plugs and a few modest granitoid plutons have been unroofed locally.

Suite 2-Rear-arc volcanic rocks and derivative sedimentary rocks, also of late Eocene to early Miocene age, that are generally attributed to the John Day Formation crop out only to the east of the Quaternary volcanic belt but probably also extend beneath it, presumably interlayered there with rocks of suite 1. The volcanic rocks are predominantly ignimbrites, ash-fall deposits, and lava flows and domes, mostly of rhyolitic composition, accompanied by varied tuffaceous sedimentary rocks and subordinate amounts of mafic alkalic lavas. In western exposures, however, ash-fall and tuffaceous sedimentary deposits of andesite-dacite composition were proposed by Robinson and others (1984) to represent the interfingering of distal-arc facies of suite 1. The John Day Formation assemblage (suite 2) likewise is faulted, tilted, or weakly folded but not strongly deformed (Peck, 1964; Smith and others, 1998; Sherrod and others, 2004).

Suite 3-Virtually undeformed and unaltered arc volcanic rocks, mostly 7.5 to $3 \mathrm{Ma}$, crop out directly beneath both sides of the Quaternary volcanic belt and interfinger eastward with fluvial sedimentary deposits that filled the Deschutes Basin just east of the arc. Dominant within the range are lava flows (mafic through silicic) and, in the basin to the east, ignimbrites and fluvial sediments. Ignimbrites were common before $5 \mathrm{Ma}$ but not thereafter (Smith, 1987; Smith and others, 1987). Suite 3 is cut and partly contained by a Pliocene graben just north of our map area (Smith and Taylor, 1983). Numerous scoria cones and small shields interfinger with and overlie the sedimentary basin deposits as far as $50 \mathrm{~km}$ east of the present Cascade Range crest (Sherrod and others, 2004), suggesting that the vent belt was at least as wide in the Pliocene as during the Quaternary. Basaltic andesites dominate this suite, but eruptive products range from basalt to rhyodacite.

\section{The Quaternary Volcanoes}

The Sisters reach of the Cascade arc, which extends about $40 \mathrm{~km}$ north and south of the Three Sisters, contains at least 466 Quaternary volcanoes (Sherrod and Smith, 2000; Hildreth, 2007). Most are monogenetic, but scores of mafic shields and several stratocones are also present. At the latitude of the Three Sisters, the vent belt is about $35 \mathrm{~km}$ wide, extending about $12 \mathrm{~km}$ west and $22 \mathrm{~km}$ east of the Cascade crest. In addition, at least 450 separate vents are present on the great rear-arc Newberry Volcano edifice, adjacent to the east. Along the arc itself (fig. 1), the nearest substantial evolved (nonmafic) centers are Mount Jefferson (60 km north) and Cappy Mountain (90 km south). Large mafic edifices, however, are especially common along this reach of the arc (fig. 4); these include Mount Washington, Three Fingered Jack, and Black Butte to the north and Mount Bachelor and many more to the south (Williams, 1957; Sherrod and Smith, 2000; Hildreth, 2007).

\section{The Mafic Periphery}

As emphasized throughout a century of geologic investigations in the Three Sisters region, a central area of more evolved (andesitic to rhyolitic) and relatively young volcanic rocks, focussed on and around South Sister and Middle Sister, is almost completely surrounded by mafic eruptive centers (figs. 2, 4; see also Hodge, 1925; Williams, 1944; Taylor, 1990). Most of the peripheral mafic centers are middle and late Pleistocene, older than the evolved central complex (largely $50 \mathrm{ka}$ and younger), although the distributed mafic volcanic fields around McKenzie Pass to the north and Mount Bachelor to the southeast are both younger.

One of the oldest mafic volcanoes in the near periphery is The Wife $(\sim 375 \mathrm{ka})$, a large glaciated shield centered $6 \mathrm{~km}$ southwest of South Sister. Proceeding clockwise around the periphery (fig. 2), The Wife is adjoined by the deeply incised

Figure 4. Rhyolite vents of Three Sisters and rear-arc Newberry caldera (NC) region. Vent locations are from MacLeod and others (1995), Sherrod and Smith (2000), Sherrod and others (2004), and this study. All vents are Quaternary; thus, they extend the northwestward rhyolite-inception age progression across High Lava Plains (HLP; see fig. 3). Rhyolites are as old as 1.1 to $0.8 \mathrm{Ma}$ just east of Newberry caldera, and they are middle Miocene to Pliocene on High Lava Plains farther southeast. Surficial deposits of Deschutes River lowland near La Pine may cover additional rhyolites. True rhyolites $\left(72-77 \% \mathrm{SiO}_{2}\right)$ are rare in Quaternary Cascade arc and are almost absent along arc everywhere north of Lassen segment (Hildreth, 2007), except within Three Sisters volcanic cluster. Rhyolites on Newberry Volcano edifice, within Three Sisters cluster, and in between are all of middle or late Pleistocene or Holocene age. Trend of Cascade arc here is north-south, as depicted by belt of selected major shield volcanoes and stratovolcanoes. Abbreviations for shield volcanoes and stratovolcanoes: BB, Black Butte; BC, Black Crater; Bk, Belknap Crater; BM, Browns Mountain; BT, Broken Top; CB, Charlton Butte; CrB, Crescent Butte; CM, Cultus Mountain; DM, Davis Mountain; GB, Gilchrist Butte; HB, Hamner Butte; HM, Horse Mountain; IM, Irish Mountain; KM, Koosah Mountain; LB, Little Brother; LM, Lookout Mountain; MB, Mount Bachelor; MxB, Maxwell Butte; MM, Maklaks Mountain; MP, Maiden Peak; MS, Middle Sister; MW, Mount Washington; NS, North Sister; OB, Odell Butte; PB, Pringle Butte; PM, Packsaddle Mountain; RB, Ringo Butte; RM, Royce Mountain; SB, Sphinx Butte; SaM, Sand Mountain; ScM, Scott Mountain; SM, Sheridan Mountain; SP, Substitute Point; SS, South Sister; TCB, Trout Creek Butte; TFJ, Three Fingered Jack; TH, The Husband; TrH, Triangle Hill; TM, Tumalo Mountain; TT, The Twins; TW, The Wife; WM, Williamson Mountain. Abbreviations for rhyolites outside map area: 3 CB, Three Creek Butte; BF, Benham Falls; BW, Bearwallow Butte; CH, China Hat; EB, East Butte; McB, McKay Butte; MeB, Melvin Butte; PP, Paulina Peak; QM, Quartz Mountain; TMR, Tam McArthur Rim. 
Sphinx Butte shield ( $280 \mathrm{ka})$, just north of which lies the large multivent shield called The Husband (150 ka or older), centered 6 to $7 \mathrm{~km}$ west of South and Middle Sisters. The northwest and northeast sectors of the mafic periphery are occupied, respectively, by the dissected Little Brother shield ( 48 ka) and the towering ice-ravaged cone of long-lived North Sister ( $\sim 120$ to $45 \mathrm{ka}$ ). Just north of this pair spreads the postglacial McKenzie Pass volcanic field (fig. 2), marked by numerous mafic vents (mostly 4 ka to $1.5 \mathrm{ka}$; Sherrod and others, 2004). Trout Creek Butte, a large mafic shield and the oldest eruptive unit in the map area $(\sim 530 \mathrm{ka})$, lies $13 \mathrm{~km}$ northeast of Middle Sister, somewhat farther from the compositionally evolved focus than the younger mafic edifices mentioned. The eastern sector of the mafic periphery lacks a substantial edifice, but, instead, it is sprinkled with mafic scoria cones and silicic domes thought mostly to be of middle Pleistocene age (Taylor, 1987; Taylor and Ferns, 1995). To the southeast lies glacially gutted Broken Top ( 300 to $150 \mathrm{ka}$ ), an extensive mafic shield surmounted by a modest stratocone, centered only $6 \mathrm{~km}$ from South Sister. To the south, the mafic peripheral ring is completed by several small shields and lava fans (fig. 2) that include The House Rock, Koosah Mountain, Le Conte Crater, and Talapus Butte, and Katsuk Butte (all late or latest Pleistocene), as well as several postglacial mafic vents on the apron of Mount Bachelor (Scott and Gardner, 1992).

Despite an abundance of silicic andesite, dacite, and rhyolite at Middle and South Sisters, such evolved products are nearly absent at most of the vents composing the mafic periphery just outlined. A striking exception is Broken Top and the upland of middle Pleistocene volcanic rocks (the Tumalo volcanic field) that extends east of it toward Newberry Volcano (fig. 4).

\section{Broken Top and the Tumalo Volcanic Field}

A highland area of numerous distributed silicic to mafic vents east of Broken Top was called the "silicic highland" by Taylor (1978, 1987), the "Tumalo volcanic center" by Hill and Taylor (1990), and the "Tumalo volcanic field" by Hildreth (2007). The 25-km-wide vent field includes andesitic and mafic scoria cones, as well as numerous rhyolitic and rhyodacitic lava flows and domes. The Tumalo volcanic field is thought to be the source of several rhyolitic to andesitic ignimbrites and plinianfall deposits exposed near the towns of Tumalo and Bend (Taylor, 1981; Hill and Taylor, 1990; Mimura, 1992; Taylor and Ferns, 1994) that erupted between about $650 \mathrm{ka}$ and about 200 ka (Sarna-Wojcicki and others, 1989; Gardner and others, 1992; Lanphere and others, 1999; Sherrod and others, 2004). Owing to extensive cover by younger mafic lavas and glacial deposits, neither its integrity as an eruptive center nor its western limit is well defined. Because silicic lavas near Todd Lake and Tam McArthur Rim (fig. 2), each adjoining the Broken Top edifice (Williams, 1944; Taylor, 1978), erupted during the same time interval as those of the Tumalo volcanic field (Hill, 1991), they could equally well be considered parts of an extensive middle Pleistocene silicic volcanic field. Of the four nearby stratovolcanoes, South, Middle, and North Sisters are wholly younger than the distributed Tumalo activity, but the eruptive lifetime of Broken Top overlapped with it.

Volumes of three extensive ignimbrites, patchily but widely preserved in the periphery of the highland, are poorly known but are likely to be in the range of 5 to $10 \mathrm{~km}^{3}$ each. Because such volumes are near the usual threshold for caldera formation, the Tumalo volcanic field might or might not contain an unrecognized filled caldera that is obscured by products of younger eruptions. Following Hill and Taylor (1990), Sherrod and others (2004) suggested that a 5-km-wide buried source area may be centered on Triangle Hill (fig. 4), whereas Williams (1957) and Conrey and others (2002) suggested locations 5 to 8 $\mathrm{km}$ farther west (near Tam McArthur Rim) as possible sources for the youngest of them. Pinning down the source vents for the three Tumalo-field ignimbrites (the Desert Spring, Tumalo, and Shevlin Park Tuffs) remains one of the more challenging problems in Oregon Cascades volcanology.

Broken Top (9,175 ft; 2,796 m) was a modest volcano (eruptive volume, $7-10 \mathrm{~km}^{3}$ ), active in the middle Pleistocene between about 300 and $150 \mathrm{ka}$ but long extinct. Its mafic apron lavas bank against the dacitic Todd Lake volcanic pile (460 \pm 30 ka, according to Hill, 1991; see also Taylor, 1978); they also sandwich thick rhyodacite lavas at Tam McArthur Rim (213 \pm 9 ka; Hill, 1991) and near Upper Chush Falls (on topographic

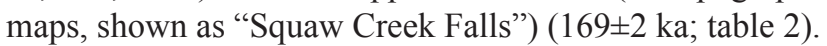
Although the basal shield, stratocone, and intrusive core of Broken Top are dominantly of basaltic andesite composition (Webster, 1992), subordinate eruptive products range from andesite to rhyodacite. Internal structure of its ice-ravaged edifice (Taylor, 1978; Grubensky and others, 1998) is well exposed on cirque headwalls, on radial ridges, and in a large southeastfacing amphitheatre of complex but uncertain origin. Cayuse Crater (fig. 2) is an unrelated postglacial basaltic (50-52\% $\mathrm{SiO}_{2}$ ) complex of lava flows and scoria cones (unit bcc) that erupted about $11 \pm 1 \mathrm{ka}$ on the southwest apron of the long-inactive Broken Top edifice.

\section{North Sister}

North Sister $(10,085 \mathrm{ft} ; 3,074 \mathrm{~m})$ is a glacially dissected stratocone of fairly uniform basaltic andesite (52.5-55.1\% $\mathrm{SiO}_{2}$; table 1; see also Taylor, 1987; Schmidt, 2005; Schmidt and Grunder, 2009), sufficiently eroded to expose hundreds of dikes and sills internally. Many dikes are zigzag or irregularly oriented within the pile of thin rubbly lava flows, but Schmidt and Grunder (2009) reported a long-term shift from edificeinfluenced radial diking toward later dominance of north-south dikes controlled by the regional stressfield. Oldest and longest active volcano of the Three Sisters, its period of construction (about $120 \mathrm{ka}$ to about $45 \mathrm{ka}$ ), nonetheless, appears to have entirely postdated that of Broken Top. Distal lavas from North Sister lie stratigraphically above the northwesternmost remnant of the Shevlin Park Tuff (unit spt), youngest ignimbrite of the Tumalo volcanic field. Although a few lavas at North Sister may be older still, the oldest reliably dated lava flow yielded an age of $119 \pm 6 \mathrm{ka}$ (unit mns; table 2). Younger parts of the 
multistage edifice (which has a few severe internal unconformities) are as young as $46 \pm 6 \mathrm{ka}$, and the summit crag yields an age of $55 \pm 5$ (all part of unit mns; table 2). It is remarkable that so mafic an edifice remained relatively monotonous compositionally during such an extended eruptive history (Schmidt, 2005; Mercer and Johnston, 2008). North Sister is part of the mafic periphery and is almost entirely older than eruptive products of the silicic focus represented by the edifices of South and Middle Sisters.

Also younger than North Sister is a late Pleistocene northtrending chain of mafic to intermediate scoria cones, lava flows, and fissure-fed agglutinates (Sherrod and others, 2004; Schmidt and Grunder, 2009), some components of which erupted through and then draped the (by then, severely eroded) North Sister edifice. Components of the chain are distributed for $11 \mathrm{~km}$ from the northwest ridge of North Sister northward past Matthieu Lakes to the shoulder of Black Crater. Another north-striking fissure vent, about $500 \mathrm{~m}$ long, unzipped down the south slope of the North Sister edifice. Although eruptive products of the several vents range in $\mathrm{SiO}_{2}$ content from 53.2 to 58.7 percent, they hold in common higher $\mathrm{FeO}$ contents $(8.1-9.5 \%)$ than central-vent products of the North Sister edifice (6.95-8.1\%). Because the components are of varied composition and of several different eruptive ages (as old as $59 \pm 4 \mathrm{ka}$ and as young as $20 \pm 5 \mathrm{ka}$; table 2 ), and because the vents are both fissural and point sourced, we prefer to call the chain the "Matthieu Lakes vent alignment." The alignment reflects the enduring influence of the region's extensional stress field, but its persistence sustains no inference of either contemporaneous magma storage or close magmatic affinity of the several batches erupted. The youngest eruptive units along the alignment (units $\mathrm{mps}$ and $\mathrm{mpn}$ ) together form a high but narrow divide that extends from the base of North Sister to the northern edge of the map area. The slender north-trending ridge formed by these strips of mafic agglutinate and scoria are an expression of their fissural eruption but may also reflect glacial confinement, owing to eruption of some about $20 \mathrm{ka}$, during the Last Glacial Maximum.

\section{South Sister}

South Sister (10,358 ft; 3,157 m), once considered the youngest stratocone in the cluster (Wozniak, 1982; Clark, 1983), is largely contemporaneous with Middle Sister. During the interval from 50 to $30 \mathrm{ka}$, South Sister was a dominantly rhyolitic volcano, consisting of numerous and varied (aphyric to phenocryst-rich) rhyolite $\left(72-74 \% \mathrm{SiO}_{2}\right)$ lava flows and domes that crop out radially on the cone up to elevations as high as $8,560 \mathrm{ft}$, within $1,800 \mathrm{ft}$ of the present summit. Around the base of the edifice, two large rhyolite domes (Kaleetan Butte and Devils Hill; units rkb and rdh) at the south toe of South Sister, as well as one near Green Lakes at the east toe (unit rgl) and a coulee along Whychus Creek northeast of the cone (unit rsf), erupted during this same time interval; all four have 74 percent $\mathrm{SiO}_{2}$. Intermediate magmatism began with the radial outflow of several dacite and rhyodacite lavas in the interval from 38 to $32 \mathrm{ka}$, alternating with the rhyolite eruptions, followed by construction of a broad cone of andesitic $\left(62-64 \% \mathrm{SiO}_{2}\right)$ lavas, $\left(62-64 \% \mathrm{SiO}_{2}\right)$, and culminating at $27+3 \mathrm{ka}$ in growth of a more steeply dipping summit cone of agglutinate-dominated andesite $\left(56-60.5 \% \mathrm{SiO}_{2}\right)$. Associated emplacement of a multiphase andesitic intrusive complex culminated in formation of a summit crater $700 \mathrm{~m}$ wide, one rim of which is exposed just inboard of Hodge Crest. Subsequent filling and overtopping of the large crater by a thick dacite lava flow (unit dlg) and more than $150 \mathrm{~m}$ of dacitic pyroclastic ejecta (unit des), followed by draping of the summit by a final thin sheet of mafic agglutinate (unit mtp; 54-56\% $\mathrm{SiO}_{2}$ ) that erupted from the much smaller present-day summit crater, together constitute a sequence that lasted until the latest Pleistocene.

After at least 15,000 years of inactivity, the South Sister locus underwent a compositional reversal, yielding two complex but separate rhyolitic eruptions at about 2.2 and $2.0 \mathrm{ka}$ (Taylor, 1978; Scott, 1987). The first episode produced the $0.5-\mathrm{km}^{3}$ Rock Mesa coulee and subordinate tephra and satellite domelets (unit rrm; altogether about $0.53 \mathrm{~km}^{3}$; all $\sim 73.5 \% \mathrm{SiO}_{2}$ ) at the southwest toe of the South Sister edifice. The second episode produced the dike-fed, 5-km-long "Devils chain" of 16 vents (unit rdc) that cuts both the 35-ka Devils Hill dome (unit $\mathrm{rdh}$ ) and the southeast flank of the South Sister edifice itself. North of a 3-km-long gap that bypasses the summit, another 1.2-km-long parallel chain of minor vents runs down the north slope of the edifice and may have been fed concurrently by the same dike system (Scott, 1987). All vents of the younger episode (altogether, about $0.32 \mathrm{~km}^{3}$ ) produced rhyolite lava or tephra that contains 72.5 percent $\mathrm{SiO}_{2}$, clearly distinguishable compositionally from rhyolite of the Rock Mesa episode. The northernmost vent of the "Devils chain" proper lies at 7,880 ft $(2,400 \mathrm{~m})$ elevation, well up the South Sister edifice and close to vents for several of the late Pleistocene rhyolites. That some 60 percent of the magma released during the younger episode issued from this uppermost vent (the Newberry flow) supports the likelihood that the rhyolitic magma reservoir lies under the South Sister edifice itself (Bacon, 1985; Scott, 1987).

\section{Middle Sister}

Middle Sister $(10,047 \mathrm{ft} ; 3,062 \mathrm{~m})$ is the youngest cone of the three, the present edifice having been built during the interval from 48 to 14 ka but mostly between 25 and $18 \mathrm{ka}$ (table 2 ), thus overlapping in time with construction of South Sister. Glaciation (persistent from the late Pleistocene to the present) has already removed much of the east half of the cone, including most of the summit-vent complex, and has sharply steepened its east face. The young cone has issued a range of mafic, andesitic, and dacitic $\left(52-65 \% \mathrm{SiO}_{2}\right)$ lavas from its central-vent area, as well as dacites from six flank vents (three of them high on the edifice) and andesites from three more. The largest dacite flank vent, which fills the saddle between North Sister and Middle Sister, built a substantial pile (informally called "Prouty Point," "Black Hump," or "Step Sister") of at least five thick flows $\left(64 \% \mathrm{SiO}_{2}\right)$ that have been dated from 27 to $18 \mathrm{ka}$. Distal mafic lavas that erupted from an older buried edifice extend eastward from beneath the limit of lavas of the modern cone and yielded ages of 180 to $160 \mathrm{ka}$. A western apron of young 
andesite-dacite lavas (48-19 ka) that erupted at Middle Sister banks against glaciated mafic centers of middle Pleistocene age. Thus, there was an extended period (more than 100,000 yr long) that had little or no activity on the site prior to initiation of modern cone growth. Eruption of the rhyolite of Obsidian Cliffs (unit roc; $38 \pm 2 \mathrm{ka}$ ) at the northwest toe of the subsequent Middle Sister edifice was one of its earliest events.

\section{Rhyolite Anomaly}

True rhyolite $\left(72-77 \% \mathrm{SiO}_{2}\right)$ is rare along the Quaternary Cascade arc (Hildreth, 2007), except in the extensional Lassen segment, at the extensional rear-arc centers (Simcoe Mountains, Newberry, and Medicine Lake volcanic fields), and here in the Tumalo-Three Sisters region at the leading edge of the cross-Oregon age-progressive rhyolite trend discussed earlier. No fewer than 15 middle Pleistocene rhyolites (including the Tumalo Tuff, not mapped herein) are exposed in the greater Tumalo volcanic field (Hill, 1991; Sherrod and Smith, 2000) between Newberry Volcano and the Three Sisters (fig. 4). In this report, we describe 14 discrete eruptive units of true rhyolite (50 to $2 \mathrm{ka}$ ) at South Sister and the Obsidian Cliffs, a highsilica rhyolite coulee (unit roc; $38 \mathrm{ka}$ ) northwest of Middle Sister. The northwesternmost rhyolite (unit r58) crops out as glaciated Dome 5803, $4 \mathrm{~km}$ north of the Obsidian Cliffs (Hill, 1991; Sherrod and others, 2004). This remarkable clustering of Quaternary rhyolites contrasts with the presence of a single rhyolite dome in the Cascade Range of British Columbia, none at all along the arc proper in Washington or northern Oregon, and only one or two along the arc between the Three Sisters and the Lassen region (Hildreth, 2007).

Some rhyolitic (and rhyodacitic or dacitic) magmas can be produced by direct partial melting of crustal rocks, with or without subsequent crystal fractionation or mixing with mafic magmas that helped heat their source. In this sense, some silicic crustal melts can be at least as primitive (near-primary) as the basaltic melts that result from the conjunction of slaband wedge-derived contributions and that undergo prolonged melt-matrix reaction during many tens of kilometers of ascent. There is broad agreement that silicic crustal melts provide persistent, varied, and substantial contributions to intermediatecomposition arc magmas that range from basaltic andesite to dacite (Smith and Leeman, 1987, 1993; Hildreth and Moorbath, 1988; Bullen and Clynne, 1990; Hill, 1991; Green, 1994; Borg and Clynne, 1998; Conrey and others, 2001b), but the petrogenetic challenge has always been to identify silicic eruptive products that approach near-primary crustal melts and to infer their source materials. For the rhyolites at Three Sisters, Tumalo volcanic field, and Broken Top, Hill (1991) showed geochemically that none could have evolved by crystal fractionation from the broadly contemporaneous dacitic or rhyodacitic magmas. Instead, Hill proposed that the Three Sisters rhyolites resulted from 20 to 30 percent dehydration-melting of basaltic amphibolite and that the Broken Top-Tumalo (slightly more sodic) rhyolites originated by 30 to 50 percent melting of deep-crustal Cascadian tonalite. Both rhyolitic suites have ${ }^{87} \mathrm{Sr} r{ }^{86} \mathrm{Sr}$ ratios in the range of 0.7036 to 0.7037 , favoring sources in Cenozoic
Cascadian-arc crust. Because both suites also have relatively undepleted and flat heavy-rare-earth-element patterns, residual garnet appears to be excluded, suggesting that melt extraction took place in the middle crust rather than in the deepest arc crust, which is here as thick as $44 \mathrm{~km}$.

As widely noted for "bimodal" extensional volcanic fields elsewhere, the elevated proportions of true rhyolite and true basalt in the Sisters reach (compared to the basaltic andesite to dacite suites that dominate adjacent reaches of the arc in Oregon) may reflect impingement on the Cascade arc by whatever combination of mantle flow and lithospheric extension has guided the progression of rhyolitic volcanism westward across the High Lava Plains and the Newberry Volcano region since the middle Miocene (MacLeod and others, 1975; Jordan and others, 2004).

\section{Composition of Eruptive Products}

Chemical data for 788 samples that represent all eruptive units defined herein are tabulated in table 1 and summarized in figures 5 and 6 . Figure 5A shows the Three Sisters suite to be calc-alkalic, having an alkali-lime index of 59, as defined by Peacock (1931). Most samples are subalkaline, as defined by LeBas and others (1986), although some intermediate products of South Sister, Middle Sister, and Broken Top overlap marginally into the trachydacite field (fig. 5A). The suite straddles broadly the tholeiitic-calc-alkaline boundary (fig. 5B) defined by Miyashiro (1974), and it largely falls within the medium-Fe field defined by Arculus (2003), although many North Sister samples and a few other units plot in the low-Fe field (fig. 5B). Nearly all samples plot in the medium-K field (fig. 5C). Some of the South Sister silicic samples in the high-K field (fig. 5C) may have been K-enriched by alkali exchange during posteruptive vapor streaming or secular hydration; the four high-K samples from Middle Sister are pristine-looking summit dacites (unit dms). The two lowest-K basalts (fig. 5C) erupted from postglacial vents at the north end of the Mount Bachelor chain (units bes and bsl); the two other basalts that have less than $0.45 \% \mathrm{~K}_{2} \mathrm{O}$ (unit bnf) are probably plagioclase accumulative (about $22 \% \mathrm{Al}_{2} \mathrm{O}_{3}$ ) and stand out (at $51 \% \mathrm{SiO}_{2}$ ) on several panels in figure 6.

Chemical-variation diagrams (fig. 6) illustrate compositional features that highlight a variety of affinities and differences among the many volcanoes in the Three Sisters cluster, some of which are summarized below.

(1) North Sister basaltic andesites (unit mns) extend to higher contents of $\mathrm{Al}_{2} \mathrm{O}_{3}(18-20 \%)$ and to lower contents of $\mathrm{Fe}, \mathrm{Ti}$, and $\mathrm{P}$ than do most other mafic products of the volcanic field, including those of nearby Little Brother, Trout Creek Butte, the Matthieu Lakes vent alignment, and the thick summit-forming pile of Middle Sister (unit mms). Products of The Wife (unit $\mathrm{mtw}$ ) and The House Rock (unit mhr), however, compositionally resemble those of North Sister. Previous studies have suggested that basaltic andesites of the central Oregon 
Cascades can be assigned to two compositional types (or end members), one relatively richer and the other poorer in $\mathrm{K}, \mathrm{Fe}, \mathrm{Ti}$, $\mathrm{P}$, rare-earth elements, and highfield-strength trace elements; the abundant data of figure 6 illustrate that such rocks $\left(52-57 \% \mathrm{SiO}_{2}\right)$ in the Three Sisters cluster form a compositional continuum.

(2) Nothing that erupted from the three main stratocones (the Three Sisters) is primitive. $\mathrm{MgO}$ contents of 135 samples of North Sister basaltic andesite (table 1; see also Schmidt, 2005) range only from 6.5 to 4.0 percent; mafic products of Middle Sister have less than 6.0 percent $\mathrm{MgO}$, and those of South Sister, less than 4.6 percent. $\mathrm{Ni}$ and $\mathrm{Cr}$ contents are correspondingly modest: North Sister has 20 to $150 \mathrm{ppm} \mathrm{Ni}$ and 40 to $150 \mathrm{ppm}$ $\mathrm{Cr}$; mafic products of Middle Sister have 25 to $80 \mathrm{ppm}$ $\mathrm{Ni}$ and 45 to $105 \mathrm{ppm} \mathrm{Cr}$; and the most mafic products of South Sister have only 12 to $30 \mathrm{ppm} \mathrm{Ni}$ and 10 to 65 ppm $\mathrm{Cr}$ (although its postglacial satellite cone, unit mlc, carries 100 to $130 \mathrm{ppm} \mathrm{Ni}$ and 150 to $205 \mathrm{ppm} \mathrm{Cr}$ ).

(3) Twenty-five of the 788 samples plotted in figure 6 contain 7 to 9 percent $\mathrm{MgO}$; they range in $\mathrm{SiO}_{2}$ content from 49 to 52 percent, and all erupted from peripheral vents. The 25 samples represent 12 map units: bbr, bes, bsl, and btk, in the south near Sparks Lake; bjc and bsb, to the southwest of the Three Sisters; bwm, to the north; bac, bsq, and bss, to the northeast; bsc, to the east; and bcc, to the southeast. Most of the 25 have 115 to 160 ppm Ni and 140 to $290 \mathrm{ppm} \mathrm{Cr}$ (table 1); only two units are still richer in these compatible elements, bcc (440 ppm $\mathrm{Cr}$ ) and bwm (as much as $213 \mathrm{ppm} \mathrm{Ni}$ and 355 ppm $\mathrm{Cr}$ ).

(4) Considering all vents in the map area, no andesite $\left(57-63 \% \mathrm{SiO}_{2}\right.$ ) has more than 4 percent $\mathrm{MgO}$ (except unit aoc); dacites have less than 2 percent, and rhyolites, only 0.6 to 0.1 percent. Most silica-variation diagrams (fig. 6) converge from broad fields of varied mafic compositions into narrowly coherent arrays that extend from 61 to 70 percent $\mathrm{SiO}_{2}$. This suggests routine mixing of the various fractionating mafic magmas to produce compositionally condensed parental lines of descent for the fractionating andesite-dacite arrays (which generally blend concurrently with silicic melts of crustal origin). Andesites and dacites of South Sister nonetheless tend to be slightly richer in $\mathrm{Mg}$ and poorer in Fe than most (but not all) of those from Middle Sister. The rarity of rocks having 70 to 72 percent $\mathrm{SiO}_{2}$ (fig. 6) suggests a role for additional processes in generating the rhyolitic magmas, probably including large contributions of intracrustal partial melts (Hill, 1991) and extraction of silicicmelt batches directly from intermediate crystal mush (Hildreth, 2004).

(5) The $\mathrm{Sr}, \mathrm{Zr}$, and $\mathrm{TiO}_{2}$ panels of figure 6 illustrate the wide ranges of large-ion-lithophile elements and high-field-strength trace elements among the varied mafic magmas that erupted in the volcanic field. $\mathrm{Zr}$ remains incompatible until the silicic-dacite range of the array, where zircon fractionation first becomes apparent and then dominates the $\mathrm{Zr}$-depletion trend among rhyolites.

(6) Most of the 70 rhyolite samples analyzed range in $\mathrm{SiO}_{2}$ content from 72 to 74.4 percent, and only unit roc (76.4-76.9\% $\mathrm{SiO}_{2}$ ) is a high-silica rhyolite. Rhyolites in the Three Sisters area are ordinary continental-margin arc rhyolites that have low $\mathrm{TiO}_{2}(0.34-0.09 \%)$, low $\mathrm{FeO}^{*}(2.2-1.0 \%)$, and moderate $\mathrm{Al}_{2} \mathrm{O}_{3}(14.6-13.0 \%)$ contents, each of which varies inversely with $\mathrm{SiO}_{2}$ content (fig. 6). All are medium- to high-K and subalkaline, and all have low abundances but wide ranges of $\mathrm{P}_{2} \mathrm{O}_{5}$ (0.18-0.02\%), $\mathrm{MgO}(0.65-0.11 \%)$, and $\mathrm{CaO}$ (1.96$0.86 \%$ ) contents. Like most arc rhyolites, those of the Three Sisters are not as highly evolved in trace-element signature as intracontinental rhyolites of various distinctive types: Cl-rich peralkaline rhyolites; F-rich topazbearing rhyolites; high-temperature, Fe-rich anorogenic rhyolites; or allanite-monazite-bearing, light-rare-earthelement-depleted, subalkaline, high-silica rhyolites. Among true rhyolites of continental margins, when compared globally, those of the Three Sisters have moderate abundances (neither strikingly high nor low) of $\mathrm{Sr}$ (104-234 ppm), Ba (800-1,070 ppm), Zn (25-45 ppm), Ce (33-58 ppm), Y (13-22 ppm), and Zr (90-300 ppm). Their slightly low concentrations of $\mathrm{Rb}(58-80 \mathrm{ppm})$, $\mathrm{Nb}(8-13 \mathrm{ppm})$, and $\mathrm{Th}(3-8 \mathrm{ppm})$ are typical of mature arcs that lack mature continental basement (Macdonald and others, 1992).

\section{Postglacial Eruptions}

Postglacial mafic eruptions are more common in the Sisters reach than anywhere else in the Cascade Range (Hildreth, 2007). In the area of McKenzie and Santiam Passes (fig. 1), more than a dozen separate mafic eruptions are radiocarbon-bracketed between 4.5 and $1.2 \mathrm{ka}$ (Sherrod and others, 2004), representing a $15-\mathrm{km}^{3}$, distributed mafic eruptive pulse in the late Holocene (Taylor, 1968). In the immediate periphery of the Three Sisters, several additional mafic vents, which include Sims Butte, Cayuse Crater, Le Conte Crater, the Mount Bachelor chain, the "Egan Cone" cluster, and the "KatsukTalapus chain" may all have erupted in the interval 17 to 8 $\mathrm{ka}$, during deglaciation or in early postglacial time. Just north of North Sister, Yapoah Crater $\left(54.5-57 \% \mathrm{SiO}_{2}\right)$ produced a lava-flow fan about $2.5 \mathrm{ka}$; Four in One Cone (56-59\% $\mathrm{SiO}_{2}$ ), another such fan at about $1.9 \mathrm{ka}$; and Collier Cone, at about 1.5 $\mathrm{ka}$, an apron as long as $13 \mathrm{~km}$ of lava flows that range in composition from 56 to 65 percent $\mathrm{SiO}_{2}$ (Schick, 1994).

Mount Bachelor, a mafic shield volcano capped by a steep mafic summit cone, lies $15 \mathrm{~km}$ southeast of South Sister. It is 


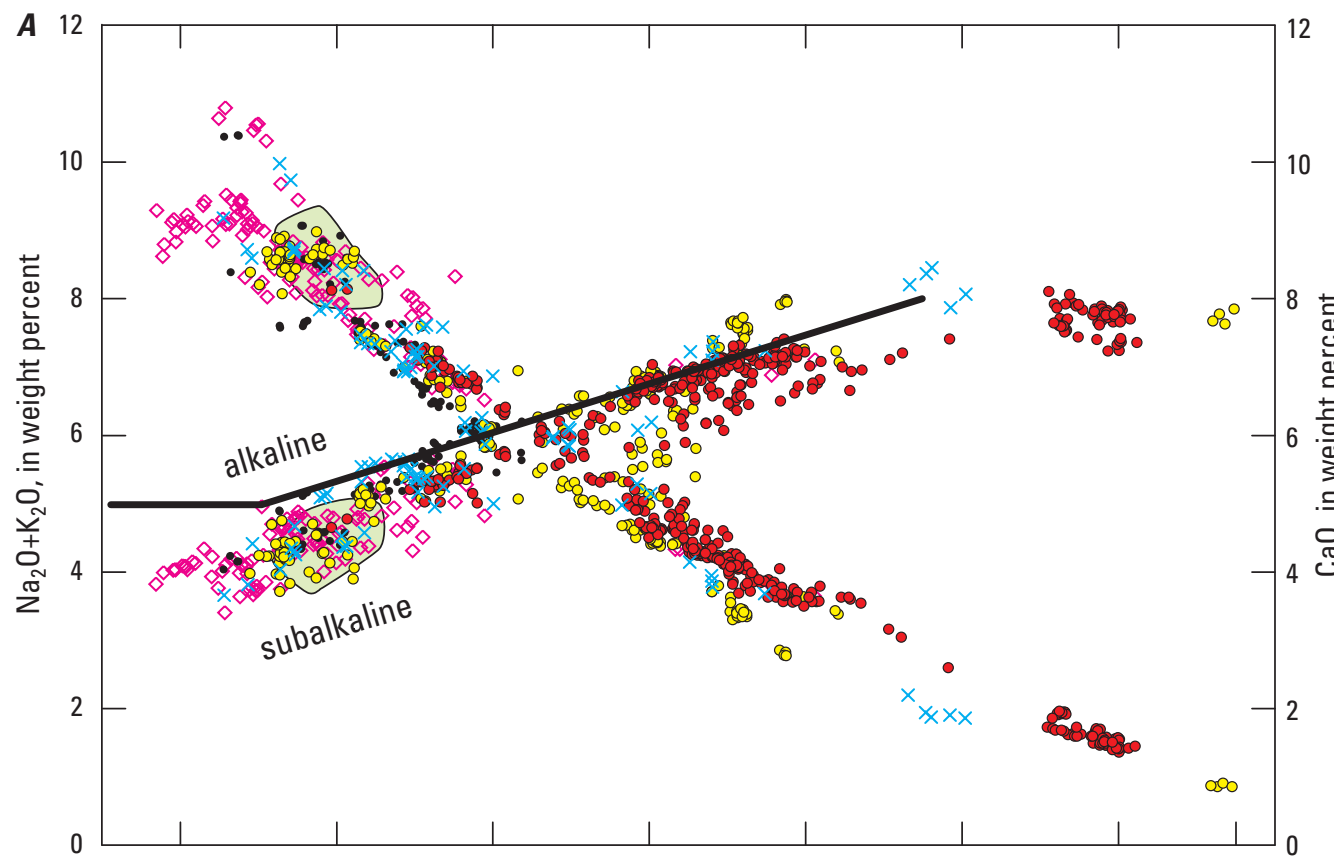

\section{EXPLANATION \\ - South Sister and vicinity \\ - Middle Sister and vicinity \\ $\times$ Broken Top and vicinity}

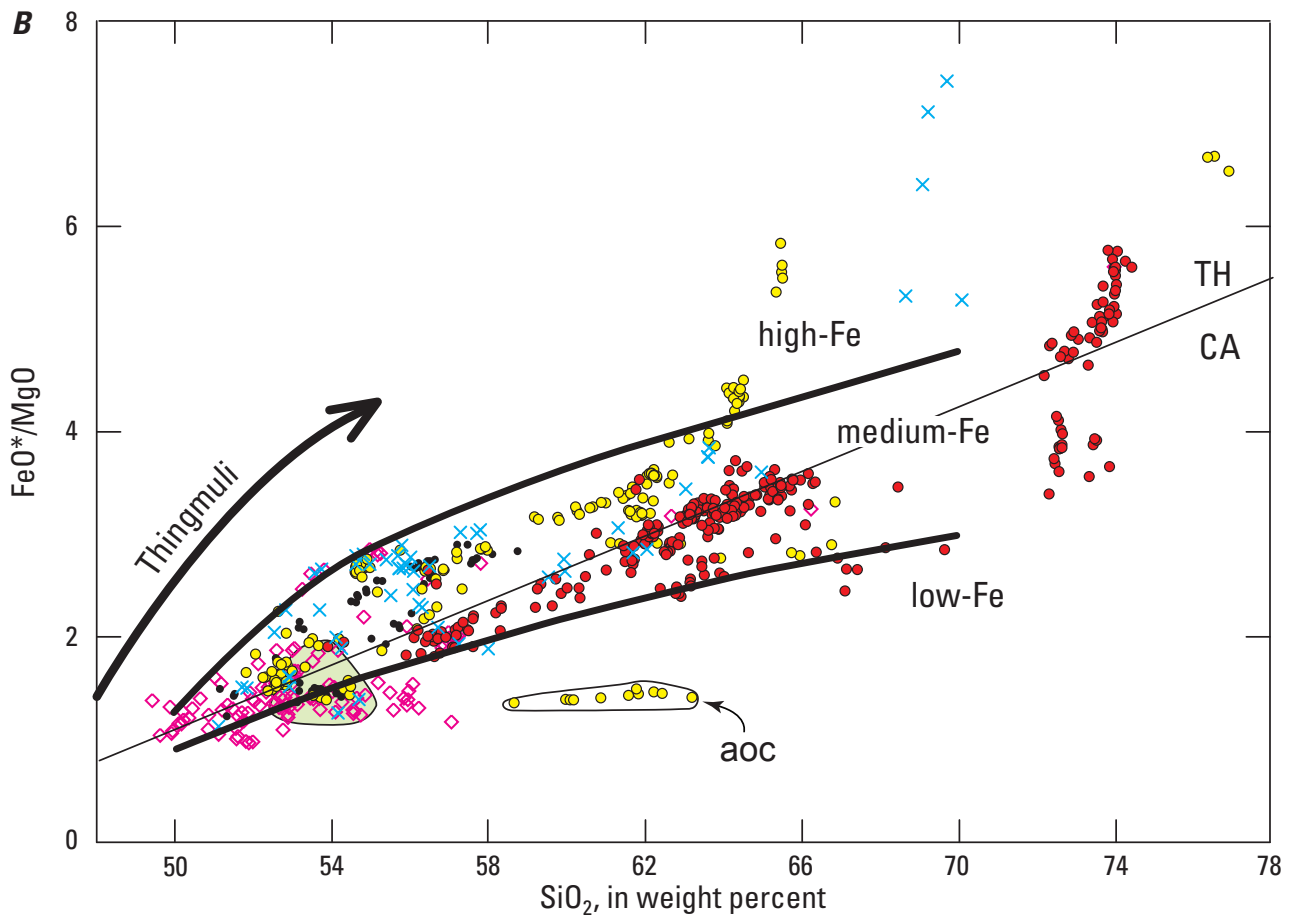

North Sister edifice

- North Sister vicinity

$\diamond \quad$ Peripheral centers and other lavas

Figure 5. Chemical variation diagrams for more than 730 samples of Quaternary eruptive products of Three Sisters volcanic cluster, subdivided as in explanation. All data are tabulated by map unit in table 1. All data are normalized to 99.6 weight percent, volatile free (leaving $0.4 \%$ for trace oxides and halogens). $A$, Total alkalies $\left(\mathrm{Na}_{2} \mathrm{O}+\mathrm{K}_{2} \mathrm{O}\right)$ and $\mathrm{CaO}$ versus $\mathrm{SiO}_{2}$. Intersection of arrays gives alkalilime index of 59, calc-alkalic suite as defined by Peacock (1931). Boundary between subalkaline and alkaline suites from LeBas and others (1986). $B, \mathrm{FeO} / \mathrm{MgO}$ versus $\mathrm{SiO}_{2}$. $\mathrm{FeO} *$ is total $\mathrm{Fe}$, calculated as $\mathrm{FeO}$. TH/CA boundary separates tholeiitic and calc-alkaline suites, as defined by Miyashiro (1974). Strongly Fe-enriching Thingmuli trend from Carmichael (1964). High-, medium-, and low-Fe suite boundaries from Arculus (2003). Data for the andesite of Obsidian Creek (unit aoc) are labelled. $\mathrm{C}_{2} \mathrm{~K}_{2} \mathrm{O}$ versus $\mathrm{SiO}_{2}$. High-, medium-, and low-K suite boundaries extended from Gill (1981). Figure 5 continued on next page.

the largest volcanic center along a $25-\mathrm{km}$-long chain of 50 vents that produced $40 \pm 5 \mathrm{~km}^{3}$ of basalt and basaltic andesite (49-57\% $\mathrm{SiO}_{2}$ ) in a few major eruptive episodes during the interval from
17 to $8 \mathrm{ka}$ (Scott and others, 1989; Scott and Gardner, 1992; Gardner, 1994). Most vents lie along a north-south alignment marked by numerous scoria cones, but most of the magma 


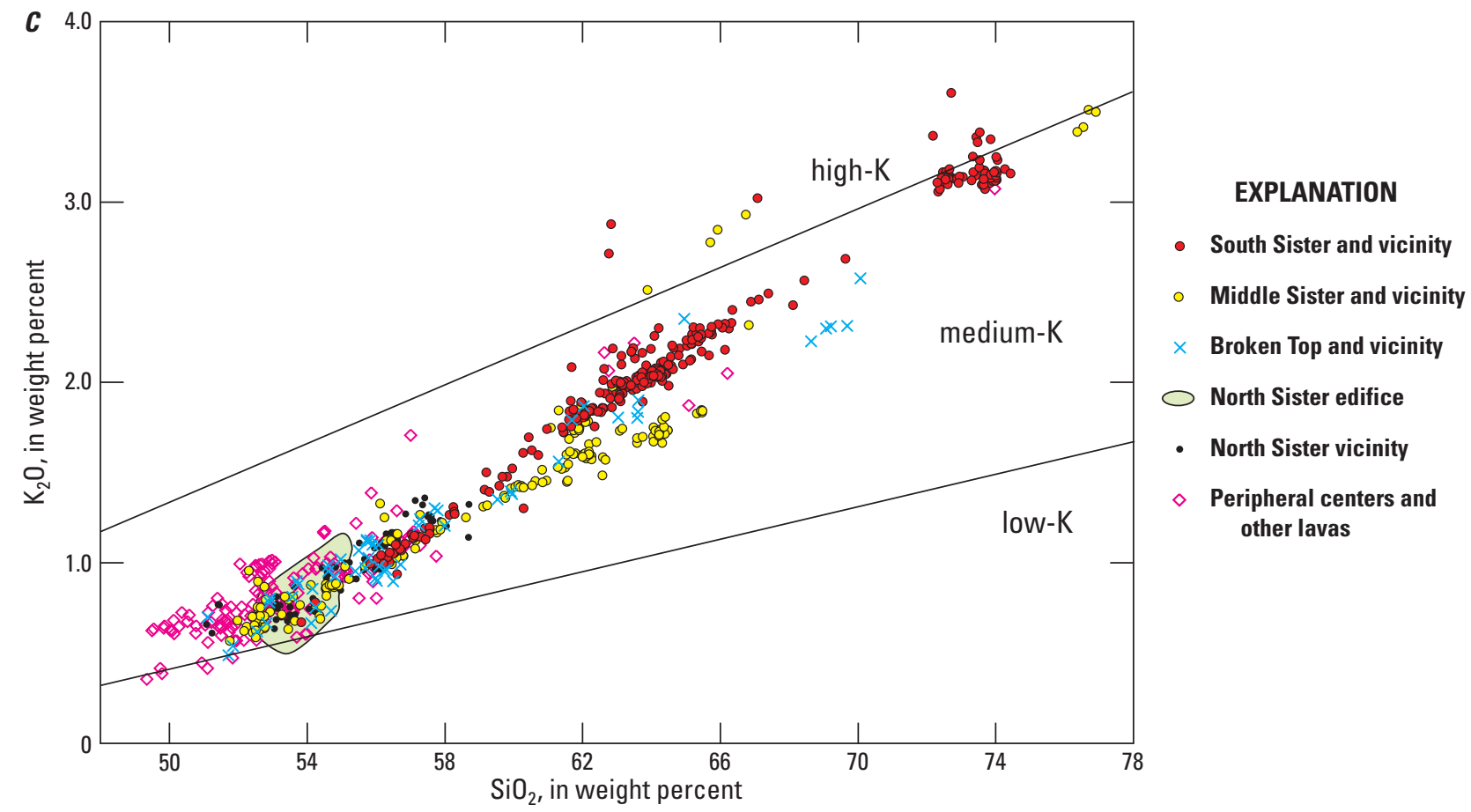

Figure 5.-Continued

issued effusively to build shields and lava fields. Five main eruptive episodes have been defined (stratigraphically and paleomagnetically) and related to late-glacial features, suggesting that most of the material erupted between 15 and $12 \mathrm{ka}$ and that as much as $25 \mathrm{~km}^{3}$ of it may have erupted in less than 1,500 years.

Comparably large effusion rates for basalt and basaltic andesite marked the late Holocene just north of the Three Sisters, in the McKenzie Pass volcanic field (fig. 2), where the 6 to $9 \mathrm{~km}^{3}$, multivent Belknap shield was constructed in less than 1,500 years (Taylor, 1965, 1968). Only slightly older than Belknap, a nearby chain of scoria cones that includes Nash Crater and Sand Mountain produced 2 to $3 \mathrm{~km}^{3}$ of Holocene mafic lavas and ejecta in about 1,000 years (Taylor, 1968; Sherrod and others, 2004).

From the Three Sisters proper, no postglacial mafic eruptions, nor any of andesite or dacite, have occurred. The only postglacial eruptions within the central volcanic focus were the late Holocene rhyolite episodes at Rock Mesa and the "Devils chain," both described in detail by Scott (1987). The stark contrast between the relative inactivity within the focal region (just two rhyolitic leaks in postglacial time) and the repeatedly voluminous postglacial mafic activity in adjacent areas both north and south plausibly attests to Holocene growth of substantial silicic-magma reservoirs that intercept ascending batches of mafic magma beneath South Sister and Middle Sister (Bacon, 1985; Scott, 1987).

\section{Volcanic Hazards}

Hazards associated with potential eruptions and slope failures in the Three Sisters region, as well as annual probabilities of several kinds of events, were summarized by Scott and others
(2001). The abundance of small mafic volcanoes, many of them postglacial, just north and south of the Three Sisters cluster is strongly suggestive of the style most likely for the next eruption: local scoria accumulation, ash fall as far as ten kilometers or more away from the vent, and slow-moving lava flows that might close a road or descend along a valley floor.

Because summit vents of the stratovolcanoes have been inactive throughout the Holocene, revival of activity high on the main cones is unexpected. Such a revival might represent either a new episode of intermediate-magma ascent from great depth or the reactivation of a shallow rhyolitic reservoir. The two important rhyolitic eruptive episodes on the apron of South Sister about 2,000 years ago were comparable in extent and volume to 10 other rhyolite eruptions that took place on the slopes of Middle Sister and South Sister in the late Pleistocene (50-25 ka). For these 10, the tephra record has been removed or concealed, but Scott's (1987) investigation of the two late Holocene eruptive episodes gave an indication of what might be anticipated in the event of another rhyolitic eruption from the reservoir that potentially still underlies South Sister. The multivent, dike-fed eruptions of Rock Mesa and the "Devils chain" both opened explosively, depositing extensive blankets of subplinian tephra fallout, as well as thin pyroclastic flows and surges that extended about $1 \mathrm{~km}$ from their vents. The $10-\mathrm{cm}$ isopach for pumiceous fallout from the Rock Mesa episode extends $17 \mathrm{~km}$ east and $13 \mathrm{~km}$ south; that for the "Devils chain" extends $11 \mathrm{~km}$ east and $6 \mathrm{~km}$ south. Ash layers about 1 $\mathrm{cm}$ thick are preserved locally as far as $20 \mathrm{~km}$ from the vents, and a trace of fine ash is detectable as far east as $30 \mathrm{~km}$, almost to Bend (figs. 1, 4). The threat of ash clouds to the engines of aircraft is well known, and even millimeters of ash fall can foul machinery, vehicles, water supplies, and the respiration of most living things. 


\section{EXPLANATION}

- South Sister and vicinity

- Middle Sister and vicinity

North Sister edifice

- North Sister and vicinity

$\times \quad$ Broken Top and vicinity

$\diamond$ Peripheral centers and other lavas

Figure 6. Plots showing $\mathrm{Zr}, \mathrm{MgO}$, $\mathrm{TiO}_{2}, \mathrm{Sr}, \mathrm{FeO}^{*}$, and $\mathrm{Al}_{2} \mathrm{O}_{3}$ versus $\mathrm{SiO}_{2}$ contents for eruptive products of Three Sisters volcanic cluster. $\mathrm{Fe} 0^{*}$ is total $\mathrm{Fe}$, calculated as $\mathrm{FeO}$. Data are divided into five volcanic groups, as in Correlation of Map Units and List of Map Units, as well as one additional grouping for North Sister edifice alone. All data are tabulated by map unit in table 1. Selected extreme or deviant units are identified by mapunit label. For example, the andesite of Obsidian Creek (unit aoc) stands out on several panels as low- $\mathrm{Ti}$, high-Mg suite that is chemically collinear with North Sister and several mafic peripheral centers. All or most samples that have more than $19.5 \%$ $\mathrm{Al}_{2} \mathrm{O}_{3}$ are plagioclase rich and are probably accumulative.
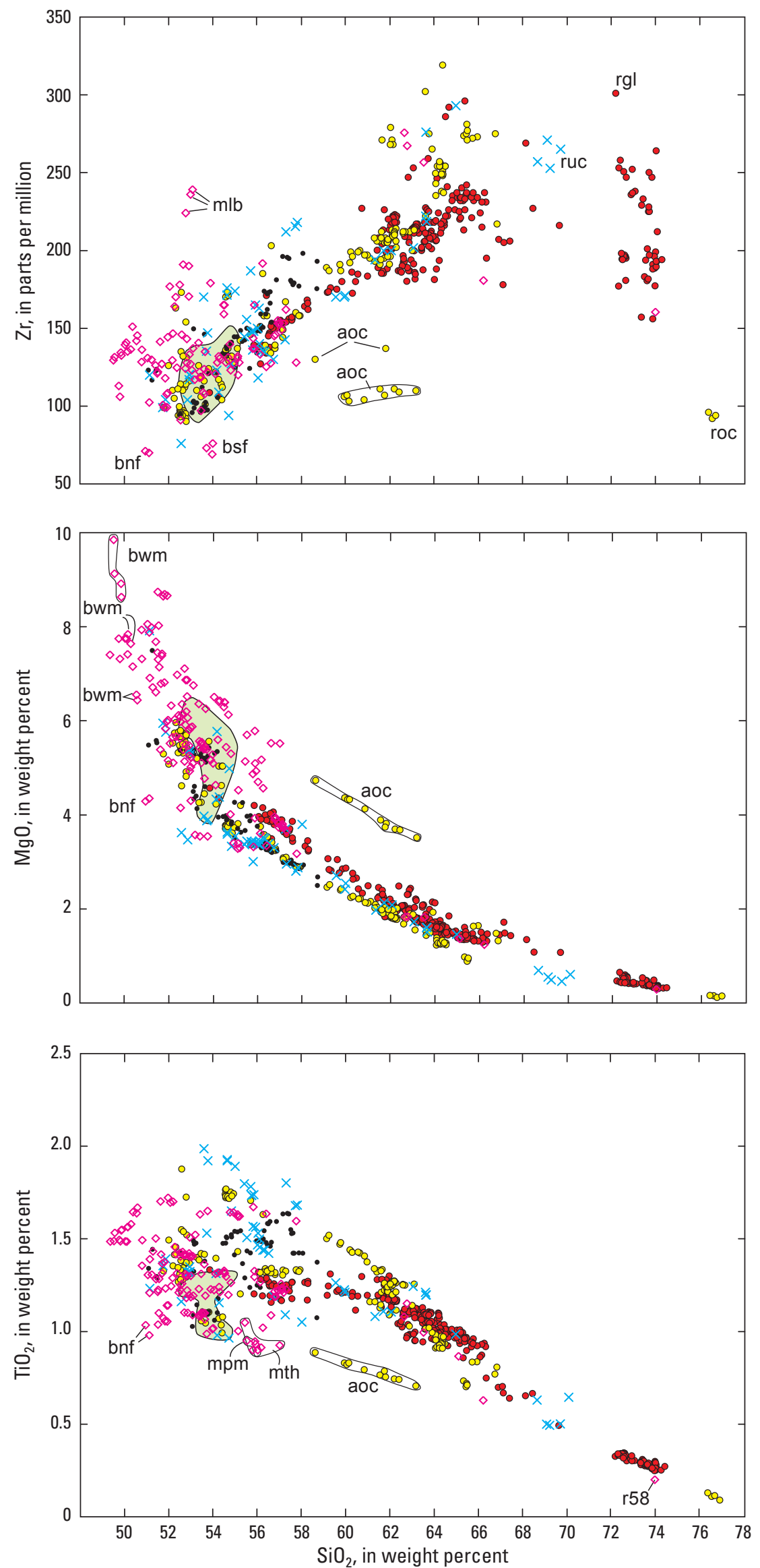


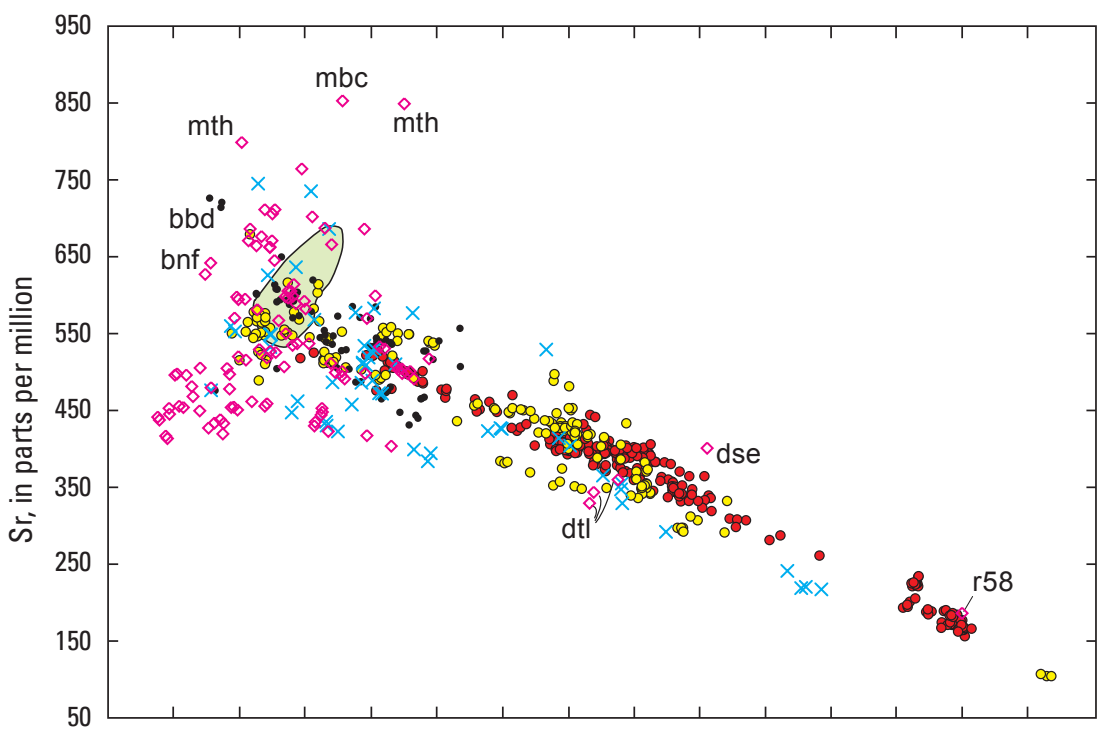

\section{EXPLANATION}

- South Sister and vicinity

- Middle Sister and vicinity

North Sister edifice

- North Sister and vicinity

$\times$ Broken Top and vicinity

$\checkmark$ Peripheral centers and other lavas

Figure 6. - Continued.
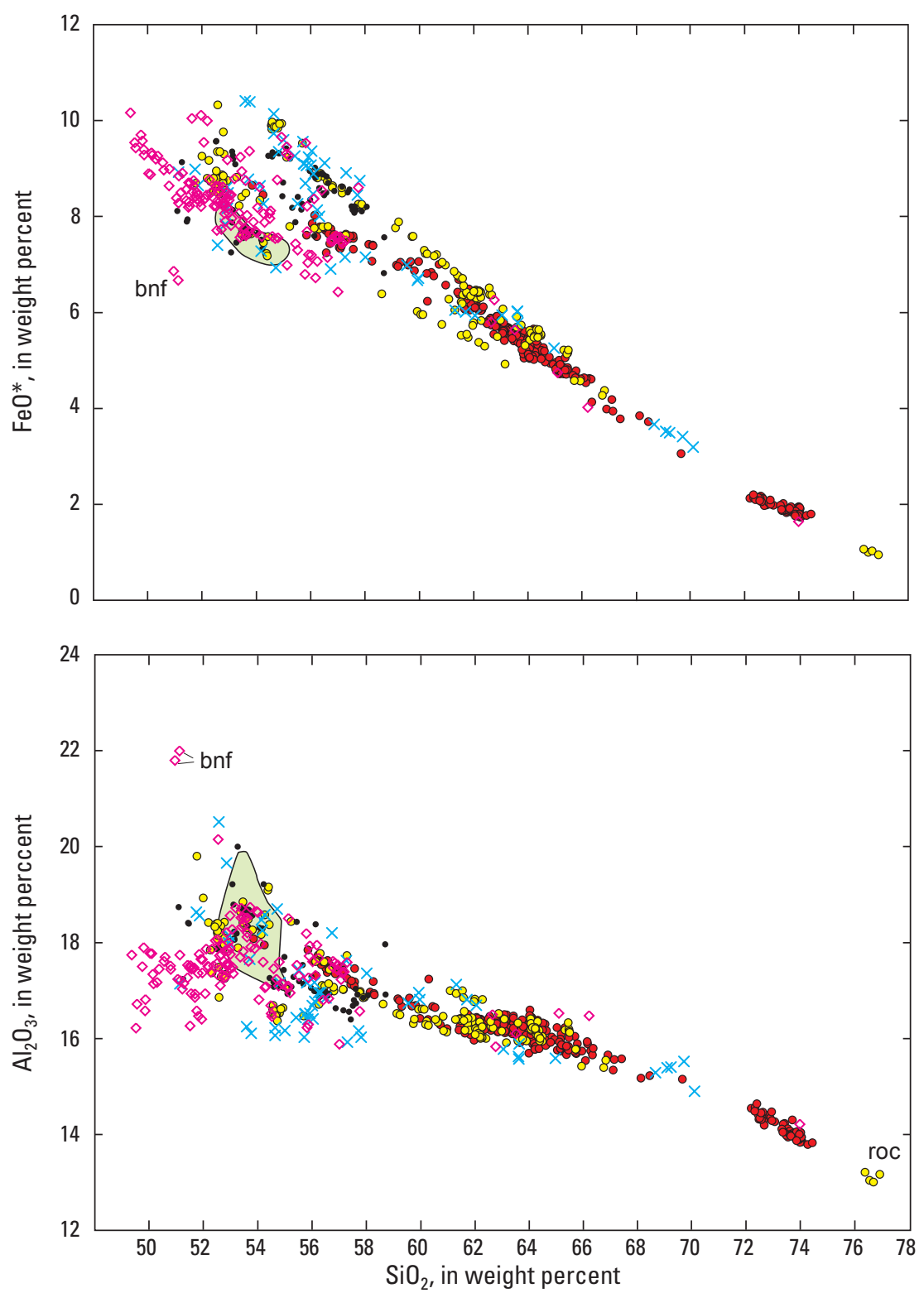
The only large Quaternary pyroclastic-flow deposits nearby are the three middling ignimbrites mentioned above, thought to have erupted in the Tumalo volcanic field in the middle Pleistocene (at roughly 650, 400, and $200 \mathrm{ka}$ ). No evidence exists for any such extensively devastating eruption during growth of the Three Sisters.

Lahars, which can result from eruptions that melt snow and ice, from breaching of moraine-dammed lakes, or from voluminous avalanches from steep edifices into stream valleys, have the capacity, if large enough, to be destructive far downstream (as discussed extensively for this area by Scott and others, 2001). Within our map area, stream valleys susceptible to such devastation include the many forks of Whychus Creek (which drains toward the town of Sisters), as well as White Branch and forks of Separation and Linton Creeks (all of which drain to the McKenzie River). Lakes susceptible to rapid breakout include moraine-dammed Carver Lake (O'Connor and others, 2001) and lava-dammed Sparks, Linton, and the Green Lakes, which would require influx of a major debris load to overtop their outlets.

\section{Acknowledgments}

We are grateful to Dave Tucker, George Cagwin, and Dean Miller for field assistance; to Ed Taylor for decades of field mapping and generous transfer of unpublished information; to Willie Scott for cogent field and logistical advice; to Julie Donnelly-Nolan for helpful project oversight and for encouraging us to undertake it in the first place; to Mariek Schmidt for her study of North Sister; and to James Saburomaru and Dean Miller for essential laboratory work. Helpful reviews of the map and manuscript were provided by Scott and by L.J. Patrick Muffler.

\section{Introduction to Description of Map Units}

The geologic map of the Three Sisters volcanic cluster represents part of a late Quaternary volcanic field within which scores of eruptions have taken place over the last 50,000 years, some as recently as about 1,500 years ago. No rocks of early Pleistocene (or older) age crop out within the map area, although volcanic and derivative sedimentary rocks of Miocene and Pliocene age are widespread to the east and west and are certainly buried beneath the younger volcanic field. Of the 145 volcanic map units described below, only 22 are certainly older than late Pleistocene (older than $126 \mathrm{ka}$ ), and 12 are postglacial (younger than about $15 \mathrm{ka}$ ). The oldest unit identified yielded an age of $532 \pm 7 \mathrm{ka}$, and the second oldest, $374 \pm 6$ ka. Compositionally, 10 percent of the units are true basalt; 36 percent, basaltic andesite; 20 percent, andesite; 21.5 percent, dacite; and only 12.5 percent, rhyodacite or rhyolite.

Volcanic-rock nomenclature, which is kept simple here, is based principally on $\mathrm{SiO}_{2}$ contents. Basalt has 47-52\% $\mathrm{SiO}_{2}$; basaltic andesite, 52-57\%; andesite, 57-63\%; dacite, 63-68\%; rhyodacite, $68-72 \%$; and rhyolite, more than $72 \%$. For reasons of convenience or uncertainty, we sometimes use the terms "mafic" to lump basalt with basaltic andesite, "intermediate" for andesite-dacite, and "silicic" to cover the range of rhyodacite and rhyolite. In unit descriptions, we sometimes state the number of samples analyzed; for example, " $n=10$ " indicates that ten samples were analyzed from that unit.

In unit descriptions, we abbreviate names of some common volcanic phenocrysts as follows: clinopyroxene, cpx; orthopyroxene, opx; plagioclase feldspar, plag. Phenocrysts are defined here as $0.5 \mathrm{~mm}$ and larger; microphenocrysts (mph), 0.1 to 0.4 $\mathrm{mm}$; and microlites, smaller still. The modifier "phenocrystrich" means that a rock has $12 \%$ or more crystals larger than 0.4 mm; "phenocryst-poor" signifies 5\% or less; "aphyric" means what it says - none. Rocks containing 6 to $12 \%$ phenocrysts we typically characterize as moderately porphyritic or of moderate phenocryst content. Because crystal sizes vary widely for each species within most thin sections (and more so within most map units), we give estimates of combined abundance of phenocrysts and microphenocrysts for each species in each unit, followed parenthetically by the size range measured in thin section for each, from microphenocrysts $(>0.1 \mathrm{~mm})$ to the largest crystal observed: for example, $7-10 \%$ plag (mph to 4 $\mathrm{mm}$ ); $2-3 \%$ pyroxenes (mph to $1.5 \mathrm{~mm}$ ); and sparse oxide mph. No systematic attempt was made here to estimate separately the proportions of opx and cpx nor to estimate quantitatively the proportions of oxide microphenocrysts present (titanomagnetite, ilmenite, and their oxyexsolved daughters, which are rarely larger than $0.3 \mathrm{~mm}$ and seldom more abundant than $0.1-0.3 \%$ ).

Most of the 145 volcanic map units described herein are newly defined, although equivalents of several were described by Taylor (1978, 1987), Scott (1987), and Scott and Gardner (1992). Each is an eruptive unit derived from a single vent or fissure. Some are simple flow units, but many are shields, cones, or stacks of several lava flows that have chemical and mineralogical coherence. Each unit has been delineated by field mapping on foot, its integrity having been confirmed, challenged, or revised by chemical and microscopic work in the laboratory. Definition of a few units required iterative acquisition of field and lab data over a period of years, providing a firm basis for subdividing, lumping, or correlating slightly heterogeneous sequences of lavas. Most units have narrow compositional ranges, but some show zoning or heterogeneity spanning ranges of a few percent $\mathrm{SiO}_{2}$.

$\mathrm{SiO}_{2}$ contents reported in the volcanic unit descriptions are based on major-element analyses (table 1) normalized on an anhydrous basis, as determined by x-ray fluorescence methods, in either the U.S. Geological Survey laboratory at Lakewood, Colorado (supervised by J.E. Taggart), or in the Washington State University GeoAnalytical Laboratory (supervised by J.A. Wolff).

Ages are estimated for all units, on the basis of their mutual stratigraphic positions and their relations to glacial deposits and erosion, as well as numerous new ${ }^{40} \mathrm{Ar} /{ }^{39} \mathrm{Ar}$ age determinations (table 2), and a few new K-Ar ages (table 3). All units mapped are Quaternary. Boundaries between early, middle, and late Pleistocene are widely agreed to be about 780 $\mathrm{ka}$ and about $126 \mathrm{ka}$ (Gradstein and others, 2004). The formally 
defined boundary between the Pleistocene and Holocene is not very useful here, even if modified to $11.7 \mathrm{ka}$ (Walker and others, 2009); accordingly, we refer to some units as postglacial or "latest Pleistocene" if they erupted subsequent to the widespread recession of glacial ice that took place in the Oregon Cascade Range during the interval from 18 to $15 \mathrm{ka}$. The radioisotopic age determinations were made in the U.S. Geological Survey geochronology laboratory at Menlo Park, California (supervised by Calvert), following methods described in Calvert and Lanphere (2006) and Hildreth and others (2007).

Locations of most geographic features cited in the text are shown in figures 1 and 2 . Elevations are given in feet $(1$ $\mathrm{ft}=0.3048 \mathrm{~m} ; 1 \mathrm{~m}=3.2808 \mathrm{ft}$ ) because the $1: 24,000$-scale topographic maps upon which the geologic map is based are available in feet only. All other measurements are metric. Grid references to site locations mentioned in the text are given to the nearest $100 \mathrm{~m}$ using the Universal Transverse Mercator (UTM) grid (1927 North American datum, zone 10), which is shown on U.S. Geological Survey topographic maps of the area. The first three digits are easting, and the second three are northing: for example, the summit of Middle Sister is approximated as 973/889 (97.3 km east, $88.9 \mathrm{~km}$ north). Occasionally, a fourth digit is added for precision to $10 \mathrm{~m}$. At the end of each unit description, the name of the U.S. Geological Survey $7.5^{\prime}$ quadrangle(s) in which the unit crops out is indicated in brackets, using the following abbreviations: BT, Broken Top; LL, Linton Lake; NS, North Sister; SS, South Sister; and TCB, Trout Creek Butte.

\section{DESCRIPTION OF MAP UNITS}

\section{SURFICIAL DEPOSITS}

i Glacial ice (late Holocene) - Present-day (2009) glaciers. Because all are currently shrinking, contacts with ice-cored moraines are actively shifting and, thus, are only approximate. Area and volume estimates (as of 1981) for all 16 glaciers on Three Sisters, including measured ice-radar thicknesses for six of them, were given by Driedger and Kennard (1986) [NS, SS]

Pumice deposits (late Holocene) - Pumice-fall deposits, local proximal pyroclastic-flow deposits, and reworked secondary deposits resulting from eruptions of units rrm and rdc. Shown only where thick enough to obscure underlying rock units sufficiently to prevent inference of their extent. See units rrm and rdc for discussion of regional extent of tephra fall, as mapped by Scott (1987) [BT, SS]

pdf Pumiceous debris-flow deposits (late Holocene) - Local tongues of rhyolitic pumice and ash, a few meters thick, that overlie parts of southwestern lava-flow lobe of Newberry flow (unit rdc), as discussed by Scott (1987). Deposits were remobilized (over snow?) from syneruptive pumice-fall deposits that accompanied extended extrusion of compound flow [BT, SS]

Alluvium (Holocene) - Unconsolidated, water-transported mud, sand, gravel, and coarser debris deposited in or adjacent to present-day (2009) streams, lakes, and swamps. Includes a few pond and lake deposits and debris-flow levees along streams. Many small deposits have been omitted, particularly along narrow streambeds. Includes some debris-flow deposits that resulted from lake breakouts related to failure of moraine dams, as mapped by O'Connor and others (2001) [BT, LL, NS, SS, TCB]

g Glacial deposits, undivided (Holocene and late Pleistocene)_-Till and minor amounts of associated glacial-outwash gravels. Till makes up many well-formed moraines, as well as extensive or patchy deposits that form irregular topography; consists of poorly sorted, boulder-rich, gravelly, silty sand. Moraine crests of four age groups are indicated by different styles of lines: Little Ice Age (late Neoglacial); early Neoglacial (about 5 to $2.5 \mathrm{ka}$ ); latest Pleistocene readvance (roughly equivalent to Younger Dryas of Europe, about 13 to $12 \mathrm{ka}$ ); and late Pleistocene (roughly 25 to $17 \mathrm{ka}$, including Last Glacial Maximum). Age assignments, in part, follow O'Connor and others (2001) and Marcott and others (2009). Little Ice Age moraines high on Three Sisters edifices are steep and sharp crested, and they commonly rise more than $100 \mathrm{~m}$ above adjacent terrain; they were deposited during last few centuries (1500-1900 C.E.) and remain barren. Early Neoglacial moraines were largely buried or removed by Little Ice Age advance, but a few surviving remnants are mapped below Prouty, Hayden, and Diller Glaciers. Modest readvance of latest Pleistocene glaciers, as documented elsewhere in Oregon Cascade Range by Scott (1977), left moraines typically 1 to $3 \mathrm{~km}$ downslope from Neoglacial moraines. Constructional moraines of late Pleistocene age are well represented in northeastern part of our map but generally lie outside map area 
elsewhere. No still-older glacial deposits have been confirmed here, with exception of single exposure at 6,060 ft elevation along North Fork Whychus Creek (UTM grid 018/889), where window of till is overlain by unit adl ( $24 \pm 1 \mathrm{ka})$ [BT, NS, SS, TCB]

Surficial deposits, undivided (Holocene and late Pleistocene) - Generally a combination of glacial, fluvial, pond, and reworked pumice-fall deposits or accumulations of till, talus, protalus, or other colluvium. Widely omitted; mapped where contacts of underlying units are badly obscured. Large area between Devils Hill and Goose Creek consists of poorly exposed Pleistocene moraines mantled by late Holocene rhyolitic-pumice deposits many meters thick but variably reworked [BT, LL, NS, SS, TCB]

Debris-avalanche deposit (Holocene or latest Pleistocene) - Mapped only at east edge of map area as swath more than $7 \mathrm{~km}$ long and 1 to $2 \mathrm{~km}$ wide, extending from south of Park Meadow to near Upper Chush Falls (on topographic maps, shown as "Squaw Creek Falls"). Abundant hummocks and crags are 10 to $50 \mathrm{~m}$ across, 1 to $8 \mathrm{~m}$ high, and internally shattered or disrupted; they consist of phenocryst-poor and phenocryst-rich andesite $\left(57-58 \% \mathrm{SiO}_{2}\right)$ lavas, stratified scoria, and tack-welded to dense agglutinate, mostly oxidized brick red. Avalanche descended East Fork Park Creek, evidently derived from failure of north slope of Broken Top edifice, possibly during deglaciation; it then crossed what is now Park Meadow, deposited blocks of agglutinate as big as $4 \mathrm{~m}$ as high as $60 \mathrm{~m}$ up west wall above modern meadow surface, and continued at least $6 \mathrm{~km}$ farther downvalley. Exposures of nonlithified diamict deposit are more than $10 \mathrm{~m}$ thick along Park Creek gorge just north of Park Meadow and more than $15 \mathrm{~m}$ along East Fork Park Creek gorge south of meadow; hummocks rise additional 1 to $6 \mathrm{~m}$ above general deposit surface. Craggy block of red blobby agglutinate beside trail on west side of Park Meadow (UTM grid 0355/8525) is $5 \mathrm{~m}$ high, 4 $\mathrm{m}$ thick, and 8 to $10 \mathrm{~m}$ long, rising sharply above 20 -m-wide apron of its own disintegrating rubble; within this agglutinate, a homogenized layer, 5 to $40 \mathrm{~cm}$ thick, of platy gray andesite $\left(58 \% \mathrm{SiO}_{2}\right)$ lava stands vertical, showing that whole block has rotated about $90^{\circ}$. Such fragile blocks and numerous hummocks have not been overrun by ice, and it is unlikely that they were transported far on glacier surface after first coming to rest. If avalanche overran stagnant and wasting valley glacier at close of Pleistocene glaciation, it might help account for excess elevation and better preservation of megablocks and hummocks on valley walls but generally smaller blocks and more subdued hummocks protruding from thick avalanche deposit along lowland axial meadows. Overlies late Pleistocene glacial deposits and units awf, drm, mpm, and ruc [BT, TCB]

Is Landslide deposit (Holocene or latest Pleistocene)_-Mapped only as single complex slump deposit from steep west side of Katsuk Butte (unit btk), probably deposited soon after deglaciation, as discussed by Scott and Gardner (1992). Includes rotated megablocks and chaotic rubble. Overlain by unit mlc [SS]

\section{VOLCANIC ROCKS}

[Listed alphabetically by 3-letter map-unit label]

abt Andesite and dacite of Broken Top (middle Pleistocene) - Varied apron of glaciated andesitic and dacitic (59.5-68.6\% $\mathrm{SiO}_{2}$ ) lava flows on southwest slope of Broken Top volcano, shown only west and southwest of Cayuse Crater. Interstratified with more mafic lavas (see unit $\mathrm{mbt}$ ) that make up much of Broken Top edifice (which we reconnoitered only as limit to our mapped area). Includes varied andesite flows containing 5-25\% plag (1-3 mm), cpx, opx, and olivine, as well as at least three dacite flows that contain 1-10\% plag and sparse pyroxenes. Underlain and overlain by mafic lava flows from Broken Top (unit mbt) and overlain by lavas and ejecta from Cayuse Crater (unit bcc). Eruptive ages probably mostly 300 to $150 \mathrm{ka}$; dacite lava at $5,820 \mathrm{ft}$ elevation on west bank of Fall Creek yielded ${ }^{40} \mathrm{Ar} /{ }^{39} \mathrm{Ar}$ age of $178 \pm 1 \mathrm{ka}[\mathrm{BT}]$

Andesite of Collier Cone (Holocene)-Andesitic scoria cone (stippled on map), $160 \mathrm{~m}$ high and $700 \mathrm{~m}$ in diameter, centered $2.5 \mathrm{~km}$ northwest of summit of North Sister, and western lavaflow apron that divides into northwestern tongue that extends $4 \mathrm{~km}$ from vent and narrow western tongue that extends $13 \mathrm{~km}$. Both tongues have several levees and remain coarsely blocky, scoriaceous, and little eroded. Flow sequence was subdivided into five distinguishable subunits (not shown separately here) by Schick (1994); first four range in $\mathrm{SiO}_{2}$ content 
from 55 to $61 \%$, whereas fifth is small proximal flow only $500 \mathrm{~m}$ long that has $65 \% \mathrm{SiO}_{2}$. Compositional range was attributed by Schick to crystal fractionation, to mixing with plutonic xenoliths $\left(69-74 \% \mathrm{SiO}_{2}\right)$ found partially melted and disaggregating in all subunits, and to entrainment of olivine and plag cumulates. Short fountain-fed lava flow $\left(57.5 \% \mathrm{SiO}_{2}\right)$ just north of cone is compositionally similar to andesitic parts of main apron. Crystal contents highly varied: $5-25 \%$ plag $(<1-8 \mathrm{~mm}) ; 1-5 \%$ olivine $(<1-4 \mathrm{~mm})$; trace mph of cpx and Fe-Ti oxides. Younger than all volcanic units nearby. Little Ice Age till banks against south slope of scoria cone. ${ }^{14} \mathrm{C}$ age: about 1,500 calibrated yr B.P. (Taylor, 1968, 1981; Sherrod and others, 2004) [LL, NS] $\mathrm{SiO}_{2}$ ) scoria cone (stippled on map) on south bank of Pole Creek (south of Trout Creek Butte) and lava-flow apron $2 \mathrm{~km}$ farther east, just outside limit of late Pleistocene moraine deposits. Lava apron is scoriaceous, rubbly, and widely oxidized on its surface, massive and block jointed on streambank scarps, and virtually aphyric. Scoria cone covers area of 400 by $600 \mathrm{~m}$ and has about $110 \mathrm{~m}$ of relief; it mainly consists of loose oxidized scoria lapilli and bombs, but ejecta on steep north slope are widely agglutinated. Nearly aphyric scoriae contain only trace amounts of plag phenocrysts (rarely as big as $0.5-2 \mathrm{~mm}$ ) and rare olivine and cpx mph. Groundmass has scattered plag-lath $\mathrm{mph}$, seriate to microlites. Cone is not glacially eroded but is located right along distal limit of late Pleistocene ice advance, its southern and eastern margins abutted by outer edges of moraine deposits. West toe of cone is wrapped by younger lava flows of unit bss. Lava-flow apron overlies units mwh (195 \pm 5 $\mathrm{ka}$ ) and bwl and extends unknown distance beyond east edge of map area. Cone is directly overlain by cream to buff pumice-fall deposit as thick as $60 \mathrm{~cm}$, of unknown source; its pumice lapilli have $67.3 \% \mathrm{SiO}_{2}$, contain trace amounts of plag and cpx ( $<1 \%$ phenocrysts), and are predominantly $2-3 \mathrm{~cm}$ but as coarse as $8 \mathrm{~cm}$; its largest lithic fragments are $2-3 \mathrm{~mm}$. Undated [TCB]

Andesite dome of Lewis Glacier headwall (late Pleistocene) - Andesitic $\left(62.6 \% \mathrm{SiO}_{2}\right)$ lava dome and major apron of derivative talus that together make up two-thirds of steep wall above northeast edge of Lewis Glacier on South Sister. Most of glaciated dome remnant is blocky and strongly fractured glassy lava that envelops 25 -m-thick, massive, more coherent interior. Total thickness is now about $100 \mathrm{~m}$, but unit must have stood at least $40 \mathrm{~m}$ higher to have shed nearly 50 -m-thick talus apron exposed on its east flank. Talus is monolithologic, matrix poor, and clast supported, consisting of subangular to subrounded glassy clasts, mostly 5 to $50 \mathrm{~cm}$ across and finely vesicular; uncommon blocks are prismatically jointed, suggesting that part of talus could be proximal lags of block-and-ash flows from dome. Best outcrops (through surficial scree) are block-rich ledges, typically about $3 \mathrm{~m}$ thick, that $\operatorname{dip} 30^{\circ}$ to $35^{\circ}$ southeast. Vague layering in deposit reflects crude size segregation, having somewhat larger matrix fractions in horizons that contain fewer large clasts; a few laterally persistent, matrix richer intervals and at least five coarse ledges indicate several emplacement pulses. Subordinate sandy to gravelly matrix is made up of material comminuted from accompanying monolithologic blocks. Dome and talus are cut by three or four dikes (unit ahi), same dikes that also cut subjacent unit alh. Phenocrysts: 10\% plag (mph to $2 \mathrm{~mm}$ ); $1 \%$ pyroxenes (mph to $0.5 \mathrm{~mm}$ ), commonly in clots with plag. Northwest side of unit is truncated (together with underlying stack of andesite lava flows of unit alh) by northwest-facing wall of a paleocrater. Thick lava of unit dlg $(25.3 \pm 1.4 \mathrm{ka}, 22.3 \pm 1.6 \mathrm{ka})$ and fragmental unit $\mathrm{dbl}$ later filled paleocrater, banking against and overlying dacite dome of unit. Thick talus from dome directly underlies unit aeg (here, $27 \pm 2 \mathrm{ka}$; $28.5 \pm 2.1 \mathrm{ka}$, nearby). Undated [SS] flows that make up much of interfluve between North and South Forks of Whychus Creek. Proximal lava bench about $100 \mathrm{~m}$ thick, centered on Demaris Lake, lies $5 \mathrm{~km}$ from South Sister summit and $4 \mathrm{~km}$ from Middle Sister summit. Source vent is uncertain, as it is covered by younger lavas, but windows along North Fork Whychus Creek (through unit mcl), as far as $1.3 \mathrm{~km}$ northwest of Demaris Lake and as high as 6,620 ft elevation, favor source at or near Middle Sister. Everywhere glaciated and widely till mantled, unit extends $5 \mathrm{~km}$ northeastward from Demaris Lake, cropping out extensively north of South Fork Whychus Creek canyon. Locally vitrophyric, including many ice-contact exposures that have chunky or slender subhorizontal columns; however, glacial and fluvial erosion has widely exposed 
block-jointed to slabby or platy, variably devitrified interior facies. Phenocrysts: $15-20 \%$ plag (mph to as big as $4 \mathrm{~mm}$ ); $3 \%$ pyroxenes (mph to $1 \mathrm{~mm}$, rarely to $2 \mathrm{~mm}$ ); sparse oxide

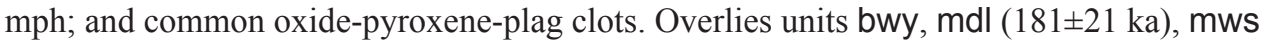
(175 $\pm 3 \mathrm{ka})$, msf ( $166 \pm 16 \mathrm{ka})$, mns (here, $119 \pm 6 \mathrm{ka})$, mnf ( $48 \pm 10 \mathrm{ka})$, and drm $(29 \pm 1 \mathrm{ka})$, as well as undated till at 6,060 ft elevation along North Fork Whychus Creek. Overlain by unit $\mathrm{mcl}(16 \pm 10 \mathrm{ka}, 23 \pm 16 \mathrm{ka})$ and by till of last Pleistocene glaciation. ${ }^{40} \mathrm{Ar} /{ }^{39} \mathrm{Ar}$ age: $24 \pm 1 \mathrm{ka}$ [TCB]

aef Andesite tephra fall at base of east face of Middle Sister (late Pleistocene) - Stratified proximal ejecta at base of headwall of Hayden and Diller Glaciers, representing stratigraphically lowest internal exposures of Middle Sister edifice. Two sequences of similar bedded ejecta (not mapped separately) are separated by smoothly bevelled unconformity; base of lower 15 -m-thick sequence is concealed by ice; upper sequence, about $30 \mathrm{~m}$ thick, is overlain by stack of ochre-weathering lava flows (unit mhd) that forms middle part of east face of Middle Sister. Both sequences dip $15^{\circ}$ to $20^{\circ}$ west beneath Middle Sister. Layers are mostly 5 to 20 $\mathrm{cm}$ thick, defined by fluctuations in sizes of coarse clasts in poorly sorted matrix that consists of very coarse ash and small lapilli. Coarse clasts are dominantly 2 to $5 \mathrm{~cm}$ (as large as 15 $\mathrm{cm}$ ), range in texture from massive to finely vesicular, and appear to be compositionally uniform andesite (62.6-63.1\% $\mathrm{SiO}_{2}$ ). Phenocrysts: $5 \%$ plag ( $\mathrm{mph}$ to $2 \mathrm{~mm}$ ); about $1 \%$ pyroxenes (mph to $1.5 \mathrm{~mm}$ ); sparse oxide $\mathrm{mph}$; also contains common crystal clots of plag, pyroxenes, and oxides. Base of unit not exposed. Overlain by lavas of unit mhd (37 $\pm 9 \mathrm{ka})$, which is, in turn, directly overlain by unit mms, which makes up upper half of east face. Stratified ejecta are cut by several dikes, which may have fed both overlying units. Undated [NS] ous thin andesitic (56.0-60.4\% $\left.\mathrm{SiO}_{2} ; \mathrm{n}=32\right)$ lava flows, agglutinate sheets, and intercalated scoria falls that make up much of upper cone of South Sister between elevations of 8,200 and $10,000 \mathrm{ft}$ (but not its summit). Glacially eroded apron extends radially downslope to 8,200 to 8,400 ft elevation on Hodge Crest (to east) and around Clark Glacier (to south and southwest), to 7,700 ft elevation near Eugene and Lost Creek Glaciers (to northwest), and to 7,600 ft elevation north and east of Carver Lake (to northeast); remnants are as low as $6,700 \mathrm{ft}$ elevation in upper Separation Creek (to northwest). Irregular upper limit of radially dipping stacks defines ragged rim of late Pleistocene crater that truncates unit; Hodge Crest, now isolated by headward erosion of cirques of Prouty and Lewis Glaciers, forms integral part of unit's slope. Paleocrater, which originally was about $700 \mathrm{~m}$ in diameter, has been wholly filled by units dlg and des. Where exposed on glacier headwalls, individual stacks consist of 4 to 15 massive gray layers, each layer typically being 1 to $5 \mathrm{~m}$ thick (rarely, 10 $\mathrm{m}$ ) and representing a discrete fountain-fed eruptive pulse. Many such (rheomorphic) massive flow units grade up, down, and proximally into agglutinate and, further, into red fragmental interlayers (also 1-5 m thick) of mixed origin: partly scoriaceous fallout (tack welded to nonwelded; rarely unoxidized) and partly scoriaceous flow-top rubble. Dense zones are texturally varied, from partly glassy to devitrified and either massively homogenized or retaining streaky to blobby ghost-agglutinate texture. Where steeply dipping $\left(20^{\circ}\right.$ to $35^{\circ}$ radially) on upper slopes, most flows are thin (and, locally, even convolutely foliated). A few northern flows that reached break in slope lower on edifice ponded to 15 to $25 \mathrm{~m}$, and some of these exhibit glassy to aphanitic, chunk-jointed features suggestive of ice contact; where incised, such thickened flows are commonly block jointed or slabby internally. On headwall of Lost Creek Glacier, stratified pile of brick-red scoria more than $100 \mathrm{~m}$ thick (stippled on map) is thought to be early phase of unit. Considerable ranges in phenocryst contents among numerous sheets that make up unit: $10-20 \%$ plag (mph to $3 \mathrm{~mm}$ ); $1-5 \% \mathrm{cpx}$ (mph to $1 \mathrm{~mm}$, rarely to $2 \mathrm{~mm}$ ); varied amounts of subordinate opx and olivine (each largely mph but as big as $1.5 \mathrm{~mm}$ ); plag + pyroxene \pm olivine \pm oxide clots range from sparse to abundant, as do oxide $\mathrm{mph}$; a few, to as many as half of, plag phenocrysts are sieved internally but overgrown by clear rims; a modest fraction of plag phenocrysts are broken. Overlies units alg, dcg, dgl, $\mathrm{drm}, \mathrm{dwl}$, rct, and rsw. Overlain by units awf, dcl, dlg, des, mtp, and rsc. ${ }^{40} \mathrm{Ar} /{ }^{39} \mathrm{Ar}$ ages: $27.0 \pm 3.2 \mathrm{ka}$ (north planèze), $26.7 \pm 1.7 \mathrm{ka}$ (Hodge Crest; south wall, Prouty Glacier), and $28.5 \pm 2.1 \mathrm{ka}$ (north wall, Lewis Glacier) [BT, SS]

ahc Andesite tephra fall of Hodge Crest (late Pleistocene) - Variably stratified, coarse andesitic $\left(61.6-61.9 \% \mathrm{SiO}_{2}\right)$ proximal fallout that extends across $700 \mathrm{~m}$ of Prouty Glacier headwall 
(South Sister). Unit is host to andesite intrusive complex of Hodge Crest (unit ahi) near southeast corner of headwall, where unit is thickest; although base there is covered by ice, fallout is more than $200 \mathrm{~m}$ thick. Lowest $60 \mathrm{~m}$ is unstratified to vaguely so, having layering that is subhorizontal to slightly outboard dipping. Upper part, which is coarser and well stratified, has layers and lenses (variably, centimeters to meters thick) that dip $10^{\circ}$ to $20^{\circ}$ inboard and that overlie unconformity that smoothly bevels outward-dipping strata below. Fallout thins northward to only $60 \mathrm{~m}$ at distance of $100 \mathrm{~m}$ from intrusive complex of unit ahi and remains well stratified throughout, having layers that dip $20^{\circ}$ to $25^{\circ}$ outboard in all but top $10 \mathrm{~m}$ or so, which dip inboard $10^{\circ}$ to $20^{\circ}$. Unconformity defined by outboard- to inboard-dipping strata may mark transient rim of paleocrater subsequently filled by overlying lava of unit dlg. Fallout was baked beneath unit dlg and is oxidized to several meters below contact. In addition, intruding dikes of unit ahi promoted hydrothermal alteration of host fallout. Coarsest part of fallout is inboard dipping and contains subrounded to angular clasts as big as $30 \mathrm{~cm}$, all dense or slightly vesicular and lithologically similar; some blocks are prismatically jointed or breadcrusted. Matrix is coarse ash, seriate to smaller clasts. Phenocrysts: $15-20 \%$ plag ( 0.5 to $3 \mathrm{~mm}$ ); 1\% pyroxenes (mph to $0.5 \mathrm{~mm}$ ), mostly in plag+pyroxene clots. Overlies unit dpg, which in turn rests on units rpg $(33 \pm 1.5 \mathrm{ka})$ and aph'. Overlain by units aeg $(27 \pm 3.2 \mathrm{ka}, 28.5 \pm 2.1 \mathrm{ka}, 26.7 \pm 1.7 \mathrm{ka})$ and dlg $(25.3 \pm 1.4 \mathrm{ka}$, $22.3 \pm 1.6 \mathrm{ka})$. Intruded by unit ahi. Undated [SS]

Andesite intrusive complex of Hodge Crest (late Pleistocene) - Family of dikes and irregular intrusions as thick as $20 \mathrm{~m}$ on both sides of saddle between Hodge Crest and South Sister summit; well exposed on headwall of Prouty Glacier and on slope northeast of Lewis Glacier. Dikes on Prouty Glacier headwall are chemically and lithologically varied. One dike that reaches rim has $60.5 \% \mathrm{SiO}_{2}$ and carries $10-20 \%$ plag (mph to $2 \mathrm{~mm}$ ) and $\sim 1 \%$ pyroxenes (mostly mph but also sparse crystals as long as $2 \mathrm{~mm}$ ), as well as common pyroxeneplag clots and oxide mph; dike resembles lava of unit awf. Another dike at base of Prouty Glacier headwall has $62.0 \% \mathrm{SiO}_{2}$ and is lithologically similar to lava of unit aph. These dikes intrude gray fragmental strata of unit ahc on Prouty Glacier headwall. On slope northeast of Lewis Glacier, three or four dikes cut stack of four lava flows of unit alh and also thick overlying unit adh; one of these dikes has $56.6 \% \mathrm{SiO}_{2}$, resembles unit aeg, and carries $10-15 \%$ plag phenocrysts and $\sim 1 \%$ olivine and pyroxene mph. Host rocks and some dikes are truncated by west-facing wall of large paleocrater, which also truncates overlying coneforming stacks of unit aeg ( $27 \pm 3 \mathrm{ka})$ and was subsequently filled by units $\mathrm{dbl}$, dlg (here, $25 \pm 1 \mathrm{ka}$ ), and des. Dikes are thought to have fed part of cone-forming unit aeg, and others may have fed lavas of units aph and awf $(24 \pm 1 \mathrm{ka})$. Intrusive complex may thus represent events spread over interval a few thousand years long. Additional dikes (not sampled) that cut unit aeg on Lost Creek Glacier headwall (west of South Sister summit) also are truncated by paleocrater wall and probably represent same time interval. ${ }^{40} \mathrm{Ar} /{ }^{39} \mathrm{Ar}$ age: $23.3 \pm 6.3$ $\mathrm{ka}$, for thick dike that cuts ridgeline saddle at Hodge Crest [SS]

ahl Andesite of headwaters of Linton Creek (late Pleistocene) - Thick andesitic (57.1-57.9\% $\mathrm{SiO}_{2}$ ) lava flow, distinguished by consistently small phenocrysts; crops out for about $1 \mathrm{~km}$ between headwaters forks of Linton Creek at elevations of 6,550 to 6,900 ft at west toe of Middle Sister. Glacially eroded unit is as thick as $70 \mathrm{~m}$; a few oxidized flow-breccia lenses appear to reflect internal shear rather than separate vent-derived flows. Most outcrops are flow foliated and at least partly glassy, although a few devitrified exposures are massive and block jointed or slabby. Widespread remnants of glassy chunk-jointed exterior of flow suggest ice contact. Separate exposure in small window about $1 \mathrm{~km}$ north (UTM grid 951/891) is largely devitrified, massive, and block jointed, and it is marked by pale- to dark-gray mottling also characteristic of main outcrops. Phenocrysts: $2-3 \%$ plag; $1-2 \%$ olivine; both plag and olivine largely $\mathrm{mph}$, but a few of each as large as $0.5-1.3 \mathrm{~mm}$; also contains sparse oxide $\mathrm{mph}$ and sparse plag-olivine-oxide clots. Overlies units alc $(27 \pm 1 \mathrm{ka})$, dlc, and $\mathrm{mhl}$. Overlain by unit mms and probably by unit dlp $(21.4 \pm 2 \mathrm{ka}) .{ }^{40} \mathrm{Ar} /{ }^{39} \mathrm{Ar}$ total-gas age: $21 \pm 3 \mathrm{ka}$ (well bracketed by ages of enclosing units) [NS]

alc Andesite of Linton Creek (late Pleistocene) - West apron of distal andesite (61.6-63.0\% $\mathrm{SiO}_{2}$ ) lava flows that extends from toe of Middle Sister edifice (where concealed more proximally by major unit $\mathrm{mms}$ ) for $7 \mathrm{~km}$ farther west-northwest, as far as Linton Lake. Medial thickness is at least $120 \mathrm{~m}$; distal relief in cliffs above Linton Lake is about $450 \mathrm{~m}$, but much of this 
owes to flow having draped stairstep topography of previously glaciated valley. Both brickred flow-breccia zone along steep margin of unit adjacent to Lane Plateau and scoriaceous flow-breccia zone along Pacific Crest Trail at 6,400 ft elevation (UTM grid 943/880) suggest two flow units, but such breaks are not exposed elsewhere. Most exposures are glassy or partly so, and many have glassy chunk jointing or inclined and subhorizontal slender columns suggestive of ice contact. Devitrified internal exposures are common where deeply incised, and they are block jointed or slabby to platy (locally convolute). Sparse pale-gray, phenocryst-poor, relatively mafic enclaves are rarely larger than $1 \mathrm{~cm}$. Highest exposure (at 6,880 ft) lies just $2 \mathrm{~km}$ west of Middle Sister summit, its presumed source. Phenocrysts: $10-20 \%$ plag (mph to $5 \mathrm{~mm}$, mostly $\sim 1 \mathrm{~mm}$ ); $2-3 \%$ pyroxenes (mph to $1.5 \mathrm{~mm}$ ), mostly in abundant clots with plag and oxides; sparse oxide mph. Overlies units mth, dlc, and mlb ( $48 \mathrm{ka})$; banks against unit aoc ( $49 \pm 4 \mathrm{ka})$. Overlain by units dlp $(21.4 \pm 1.9 \mathrm{ka}), \mathrm{mms}, \mathrm{mmt}$, and ahl $(21 \pm 3 \mathrm{ka}) .{ }^{40} \mathrm{Ar} /{ }^{39} \mathrm{Ar}$ ages: $26.8 \pm 1.2 \mathrm{ka}$ (distal), $27.2 \pm 1 \mathrm{ka}$ (proximal); same age as compositionally similar lavas of unit alg that erupted at South Sister [LL, NS] uniform phenocryst-rich andesite $\left(61.5-63.5 \% \mathrm{SiO}_{2}\right)$ lava flows from South Sister, cropping out from Neoglacial moraines of Lost Creek Glacier down to Separation and Hinton Creeks (from 7,800 to 6,400 ft elevation), 1 to $3 \mathrm{~km}$ from summit of South Sister. Stacks of flows are glacially eroded into stairstep benches. Flows are mostly 2 to $10 \mathrm{~m}$ thick upslope and commonly separated by oxidized flow breccia, whereas toward lowland extremity of unit, several flows thicken to as much as 15 to $20 \mathrm{~m}$. Sets of several shingled flows are glacially scoured into radial ridges that diverge downslope. Massive vitrophyre zones are preserved locally, but glacial erosion has been severe enough in this sector that most exposures are devitrified and platy, slabby, or block jointed. Flow foliation, locally convolute or ramped, is common, especially on higher, steeper slopes. Phenocrysts: $10-15 \%$ plag (mph to $2 \mathrm{~mm}$ ), some of larger ones sieved; $2-3 \%$ pyroxenes ( $\mathrm{mph}$ to $1.5 \mathrm{~mm}$ ); sparse olivine and oxide $\mathrm{mph}$; most pyroxenes are in clots with plag and oxides. Base not exposed. Overlain by units aeg and dwl directly and by units mms and rsc peripherally; lavas of unit msc $(21.4 \pm 5.5$ ka) appear to bank against toe of unit's apron. ${ }^{40} \mathrm{Ar} /{ }^{39} \mathrm{Ar}$ age: $27.1 \pm 1.1 \mathrm{ka}$ (essentially same age as compositionally similar lavas of unit alc that erupted from Middle Sister) [SS]

alh

Andesite of Lewis Glacier headwall (late Pleistocene) — Stack of four andesitic (62.0-62.9\% $\mathrm{SiO}_{2}$ ) lava flows separated by oxidized flow breccias in steep wall above northeast edge of Lewis Glacier on South Sister. Massive zones stand out as 2- to 12-m-high ledges on steep slope. Massive interior of fourth flow thins eastward from 6 to $2 \mathrm{~m}$, draping three underlying flows. Lowest flow is largely devitrified, platy, and oxidized pink, its base covered at glacier margin; second and third flows are dark gray or oxidized red-brown, mostly massive and partly glassy; and fourth flow is black, glassy, and vesicular. All four are cut by three or four dikes that are assigned to unit ahi. Phenocrysts: $10-15 \%$ plag (mph to $2 \mathrm{~mm}$ ), somewhat less $(\sim 10 \%)$ in lowest flow; $1-2 \%$ pyroxenes (mph to $1 \mathrm{~mm}$ ), commonly in clusters of mph or in clots with plag; more pyroxenes $(2-3 \%)$ in lowest flow; also contains abundant oxidepyroxene-plag clots. Overlain conformably by unit adh. At its west end, stack is truncated by wall of paleocrater that was filled by units $\mathrm{dbl}$ and dlg $(25.3 \pm 1.4 \mathrm{ka}, 22.3 \pm 1.6 \mathrm{ka})$, both

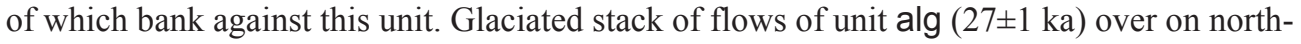
west flank of South Sister is chemically and petrographically similar to lowest flow in stack here, which yielded a ${ }^{40} \mathrm{Ar} /{ }^{39} \mathrm{Ar}$ age of $30.4 \pm 1.3 \mathrm{ka}$ [SS]

als Andesite south of Lewis Glacier (late Pleistocene) - Plagioclase-rich andesitic $\left(62.4 \% \mathrm{SiO}_{2}\right)$ lava flow at 8,600 ft elevation on South Sister that forms glaciated cliff and crags (UTM grid 990/823) beneath southeast edge of Little Ice Age moraine of Lewis Glacier; only 400 $\mathrm{m}$ from current ice front. Steep, bluff-forming lava is as thick as $60 \mathrm{~m}$ and exposes both dark-gray, partly glassy zones and pale-gray, devitrified platy zones. Lava is compositionally distinct from other nearby plagioclase-rich units (aeg, dmn, and dgl) but petrographically and chemically similar (not identical) to unit alg on west flank of South Sister edifice. Phenocrysts: $10-15 \%$ plag (mph to $3.5 \mathrm{~mm}$ ); $1-2 \%$ pyroxenes (mph to $1 \mathrm{~mm}$ ), mostly in clots with plag and oxides; free oxide mph are sparse. Overlies units dmn (here, 27.7 \pm 1.0 $\mathrm{ka})$ and rct $(24 \pm 5 \mathrm{ka}, 30 \pm 8 \mathrm{ka})$. Undated [SS]

anh Andesite agglutinate north of Hayden Glacier (late Pleistocene) - Fissure-fed andesitic $\left(57.9-58.0 \% \mathrm{SiO}_{2}\right)$ scoria, spatter, and fountain-fed lava flow that drape lower south face 
of North Sister. Upper end of 500-m-long fissure lies at about 9,100 ft elevation; lower end at about 8,200 ft; and rheomorphic lava drapes additional $500 \mathrm{~m}$ south, then southeast, to glacially eroded terminus at 7,800 ft elevation. Eroded remnants along fissure are only 50 to $100 \mathrm{~m}$ wide, but lava tongue broadens downslope over terrain less steep to about 200 $\mathrm{m}$. Agglutinate and scoria along fissure are brick red and tack welded to fairly dense but blobby; lava flow also is largely oxidized and has blobby exterior but becomes denser and more homogenized (though still streaky) distally. Terminal lobe is $25 \mathrm{~m}$ thick and contains patchy exposures of gray, massive interior; it probably ponded against ice and was subsequently overridden and surficially stripped by it. Phenocrysts: $\sim 1 \%$ plag (mostly mph, but rare crystals $0.5-1.5 \mathrm{~mm}$ in plag-pyroxene-oxide clots); rare cpx $(\leq 0.5 \mathrm{~mm})$, largely in clots; sparse oxide mph. Unit erupted through and drapes far older stack of previously eroded thin lavas of North Sister (unit mns). Overlain by Middle Sister lavas of unit mms. ${ }^{40} \mathrm{Ar} /{ }^{39} \mathrm{Ar}$ age: $21.0 \pm 6.3 \mathrm{ka}$ [NS]

aoc

apc

aph

aph'
Andesite of Obsidian Creek (late Pleistocene) - Extensive apron of phenocryst-poor andesite (59.9-63.2\% $\mathrm{SiO}_{2}$ ) lava flows that extends just beyond Linton Lake, $7 \mathrm{~km}$ from northwest toe of Middle Sister, its presumed source vent. Its most proximal exposures, where buried by younger lavas of Middle Sister, lie $3 \mathrm{~km}$ from summit of that edifice. As thick as $120 \mathrm{~m}$ at medial exposures, glacially scoured unit ponded (possibly against ice) near its terminus, where it now has $285 \mathrm{~m}$ of relief (although true thickness is less, owing to steepness of paleovalley floor it buried). Massive to columnar, black glassy base is exposed near 4,900 ft elevation along Obsidian Creek, but most exposures have been glacially sculpted into ridges and benches of devitrified, nonvesicular, fine-grained andesite that ranges from block jointed to thinly platy. Most commonly pale gray and mottled on joint planes but locally dark gray where still partly glassy. In otherwise massive devitrified rock, pale-gray films commonly accentuate pervasive hairline cracks spaced 2 to $5 \mathrm{~mm}$ apart that represent flow foliation. At snout of flow northwest of Linton Lake, thick, glassy, chunk-jointed carapace is preserved. Phenocrysts: virtually aphyric, but locally contains rare plag $(0.5-1.5 \mathrm{~mm})$, commonly rounded; rarer olivine $(\leq 0.5 \mathrm{~mm})$, typically partly resorbed and has reaction rims. Overlies unit $\mathrm{mlb}$ ( $48 \mathrm{ka}$ ). Overlain by units acc, alc, dlp, mmm, mms, mrg, and roc. ${ }^{40} \mathrm{Ar} /{ }^{39} \mathrm{Ar}$ ages: $49 \pm 4 \mathrm{ka}$ (proximally), $44.6 \pm 1.8 \mathrm{ka}$ (at distal snout). Eroded nose assigned to this unit, located about 500 m northwest of Montague Memorial Plaque (UTM grid 940/912), is lithologically identical but has only $58.6 \% \mathrm{SiO}_{2}$; apparently a discrete but related flow, it yielded ${ }^{40} \mathrm{Ar} /{ }^{39} \mathrm{Ar}$ age of $47.9 \pm 2.2 \mathrm{ka}$ [LL, NS]

Andesite of Park Creek (late Pleistocene) - Phenocryst-rich andesite (61.0-61.6\% $\mathrm{SiO}_{2}$ ) lava flow exposed discontinuously through till along West Fork Park Creek, $0.7 \mathrm{~km}$ to $2 \mathrm{~km}$ downstream from Red Meadow. Glassy zones preserved only locally in severely glaciated lava; mostly devitrified, nonvesicular, and block jointed to platy. Strikingly platy along gorge near waterfall at 5,820 ft elevation. Phenocrysts: $10-15 \%$ plag (mph to $4 \mathrm{~mm}$ ); 2-3\% pyroxenes ( $\mathrm{mph}$ to $1.5 \mathrm{~mm}$ ), mainly in plag-pyroxene-oxide clots; sparse oxide mph. Overlies unit ruc $(169 \pm 2 \mathrm{ka})$. Overlain by unit drm $(29 \pm 1 \mathrm{ka}) .{ }^{40} \mathrm{Ar} /{ }^{39} \mathrm{Ar}$ age: $31 \pm 9 \mathrm{ka}$ [TCB] Andesite of Prouty Glacier headwall (late Pleistocene)-Phenocryst-poor andesitic $\left(61.4-61.6 \% \mathrm{SiO}_{2}\right)$ lava flow that crops out as ledge at ice level for about $250 \mathrm{~m}$ along northwest base of Prouty Glacier headwall on South Sister. Most of 7-m-thick exposure is gray and partly glassy, weathered pink to buff on blocky joint surfaces; base is covered by glacier. At both ends of exposure, flow margins are enveloped in crudely stratified, oxidized tephra-fall deposit that has agglutinated lenses. Midway along ledge, exposure is conspicuous 12-m-wide hemispherical devitrified zone that has distinctively concentric platy jointing. Phenocrysts: $\sim 1 \%$ plag (mph to $2 \mathrm{~mm}$ ); sparse pyroxenes (mph to $0.5 \mathrm{~mm}$ ); sparser Fe-Ti oxides; most pyroxenes in oxide-pyroxene-plag clots. Directly overlain by stratified sequence of agglutinate and breccia (unit aph'), which is, in turn, capped by unit rpg ( $33 \pm 2$ ka). Undated. One isolated outcrop in ice, just below base of headwall and $300 \mathrm{~m}$ along strike southeast of section just described, is 4-m-thick andesitic $\left(61.6 \% \mathrm{SiO}_{2}\right)$ lava ledge, apparently also of this unit; lava is enveloped in ochre breccia that contains vesicular, black clasts of glassy lava $\left(59.3 \% \mathrm{SiO}_{2}\right)$ that probably is coarse proximal fallout more than $5 \mathrm{~m}$ thick, its base covered by ice; lithologies are similar to unit aph' [SS]

Andesite tephra fall near base of Prouty Glacier headwall (late Pleistocene) - Stratified tephra-fall deposit about $5 \mathrm{~m}$ thick that contains thin lenses and layers of massive 
andesitic (59.3-63.7\% $\mathrm{SiO}_{2}$ ) agglutinate, atop ledge of unit aph along northwest base of Prouty Glacier headwall on South Sister. Massive intervals are black, glassy, and finely vesicular, and they grade into rubbly zones above and below. Coarse nonwelded intervals contain moderately vesicular, glassy juvenile clasts as big as $20 \mathrm{~cm}$ (similar in lithology to massive layers), as well as abundant dense, angular, nonjuvenile lithic fragments; subordinate ochre coarse-ash matrix mostly consists of comminuted juvenile material. Individual nonwelded layers range laterally in thickness from $20 \mathrm{~cm}$ to $2 \mathrm{~m}$ and in color from ochre to brick red. Phenocrysts: $\sim 2 \%$ plag (mph to $1.5 \mathrm{~mm}$, rare to $3 \mathrm{~mm}$ ); sparse pyroxene (mph to $0.5 \mathrm{~mm})$. Rests on unit aph and is overlain by units rpg $(32.8 \pm 1.5 \mathrm{ka})$ and $\mathrm{dpg}$. Undated [SS]

asn Andesite south of Newberry flow (late Pleistocene) - Glaciated plagioclase-rich andesite $\left(61.7 \% \mathrm{SiO}_{2}\right)$ lava flow exposed only locally beneath snout of late Holocene Newberry flow (unit rdc), $4 \mathrm{~km}$ southeast of South Sister summit. Deeply covered by proximal rdc ejecta, unit is exposed principally as glacially eroded bench of block-jointed massive lava at 6,400 $\mathrm{ft}$ elevation. Apparently also overlain by unit rse $(34 \pm 1 \mathrm{ka})$, extensive ridge of rhyolitic lava that stands between unit and its presumed source, South Sister edifice. Phenocrysts: 7-10\% plag (mph to $2 \mathrm{~mm}$ ); $3 \%$ pyroxenes (mph to $0.7 \mathrm{~mm}$ ); sparse Fe-Ti oxides; contains abundant oxide-pyroxene-plag clots. Base not exposed. Undated [BT]

asw Andesite of southwest slope of Middle Sister (late Pleistocene) - Small window (100 by 300 $\mathrm{m})$ of phenocryst-poor andesite $\left(61.5 \% \mathrm{SiO}_{2}\right)$ lava flow near southwest toe of Middle Sister cone. First draped by extensive lava apron of unit $\mathrm{mms}$ and then jointly glaciated, exposure is, in part, devitrified, pale gray, and platy or block jointed and, in part, black, blocky, and glassy to aphanitic. Locally, unit exhibits ramped flow foliation, oxidized joint films, and scoriaceous crusts along shear planes. Phenocrysts: $<1 \%$ plag (mph to $1.2 \mathrm{~mm}$ ); sparse pyroxenes (mostly mph, but very rare crystals $0.5-1 \mathrm{~mm}$ ); sparse oxide $\mathrm{mph}$. Base not exposed. Overlain and largely concealed by unit mms. ${ }^{40} \mathrm{Ar} /{ }^{39} \mathrm{Ar}$ age: $25 \pm 4 \mathrm{ka}[\mathrm{NS}]$

asy Hornblende-bearing andesite southeast of Yapoah Crater (late Pleistocene)—Block-jointed bench of glaciated phenocryst-rich andesitic $\left(58.7 \% \mathrm{SiO}_{2}\right)$ lava that protrudes eastward from east-facing cliff of unit mwa, about $1.5 \mathrm{~km}$ southeast of Yapoah Crater. Bench is only about $100 \mathrm{~m}$ long, $60 \mathrm{~m}$ wide, and $30 \mathrm{~m}$ high, but its scarp sheds coarse talus that covers its base downslope. Lithologically unique in local area, it is either plug or remnant of unit that is elsewhere wholly concealed. Phenocrysts: $7-10 \%$ plag $(0.5-4 \mathrm{~mm}) ; 3-5 \%$ hornblende prisms (0.5-15 $\mathrm{mm}$ long), mostly opacitized; rare cpx $\mathrm{mph}(0.3-0.4 \mathrm{~mm})$; common hornblende-plag clots and clusters of plag mph. Groundmass rich in plag mph, seriate to microlites. Apparently intrudes unit mwa $(59 \pm 4 \mathrm{ka})$, but contact relations are obscured by surficial deposits. Undated [NS]

awa Andesite west of upper Alder Creek (late Pleistocene) - Phenocryst-poor andesitic (55-58\% $\mathrm{SiO}_{2}$ ) lava flows and subordinate agglutinate that form three separate cliffy exposures about $1 \mathrm{~km}$ west of upper Alder Creek. East-facing wall and buttress (UTM grid 984/936) that protrudes from it ( $1 \mathrm{~km}$ east of Collier Cone) are 40 to $90 \mathrm{~m}$ high and consist of three fountainfed lava flows that are separated by thin sheets of red agglutinate at western exposures but merge eastward into single cliff that has vertical jointing and no surviving partings. Another prominent buttress, isolated by scree just east of that wall (UTM grid 987/933) is single lava flow more than $30 \mathrm{~m}$ thick that grades down into stratified, variably agglutinated, red scoria-fall deposit more than $25 \mathrm{~m}$ thick; lava is pale gray, block jointed to slabby, and flow foliated, and it dips about $20^{\circ}$ northeast; fall deposit mostly consists of lapilli but also has bombs and dense blocks as big as $30 \mathrm{~cm}$ and numerous lenses of dense agglutinate. Third exposure, about $300 \mathrm{~m}$ northeast of first, is slender ridge (UTM grid 988/942), $600 \mathrm{~m}$ long, $100 \mathrm{~m}$ wide, and $50 \mathrm{~m}$ high, that trends N. $10^{\circ} \mathrm{E}$. and consists of single ice-sculpted lava flow; lava is massive and block jointed, and its basal oxidized breccia rests on lava flow of unit mns (xenoliths of which, $1-5 \mathrm{~cm}$ across, are common in overlying unit). Phenocrysts: $<1 \%$ plag $(0.5-2.5 \mathrm{~mm})$; rare cpx $(0.5-1 \mathrm{~mm})$; rare olivine mph. Overlies unit mns.

Overlain by pyroclastic unit $\mathrm{mps}$, which buried vent for this unit; these two phenocryst-poor units may have erupted successively from common fissure-vent system. Distinguished from unit mwa, which crops out along same wall just north, by its much lower phenocryst content, lower $\mathrm{Al}_{2} \mathrm{O}_{3}$ content $(<17 \%)$, and higher $\mathrm{FeO}$ content $(>8 \%) .{ }^{40} \mathrm{Ar} /{ }^{39} \mathrm{Ar}$ age: $25.2 \pm 2.2 \mathrm{ka}$, for lava of northeast ridge [NS] 
awc

awm

awr

awy
Andesite west of Collier Glacier (late Pleistocene)-Glaciated fan ( $2 \mathrm{~km}$ long, $1 \mathrm{~km}$ wide) of fairly uniform andesite $\left(61.6-62.3 \% \mathrm{SiO}_{2} ; \mathrm{n}=13\right)$ lava flows that extends north-northwest from Middle Sister along west side of Collier Glacier. Among numerous shingled flows, sequences of five are exposed locally along glacier-marginal cliffs. Till-strewn surface of unit is glacially eroded into radial ridges and stairstep benches cut on stack of flows 5 to $25 \mathrm{~m}$ thick, all dipping moderately northwest. Uppermost flow of unit adjacent to Collier Glacier is more than $70 \mathrm{~m}$ thick, probably ponded originally against ice. Glassy chunkjointed zones, mostly at bases of flows, crop out widely, but most rock exposed is devitrified and block jointed or platy. Phenocrysts: $5-10 \%$ plag (mph to $2.5 \mathrm{~mm}$ ); $1 \%$ pyroxenes (mph to $1.5 \mathrm{~mm})$, many in common plag-pyroxene-oxide clots; sparse oxide mph. Overlies units dss $(25 \pm 3 \mathrm{ka})$ and $\mathrm{mlb}(\sim 48 \mathrm{ka})$, which here, in turn, overlies unit mns. Overlain by units $\mathrm{mrg}(20 \pm 6 \mathrm{ka}), \mathrm{mms}$, and dbh (18 $\pm 2 \mathrm{ka}) .{ }^{40} \mathrm{Ar} /{ }^{39} \mathrm{Ar}$ ages: $21.9 \pm 1.7 \mathrm{ka}, 24.5 \pm 1.5 \mathrm{ka}[\mathrm{NS}]$

Andesite of West Fork Park Creek (late Pleistocene) - Glaciated set of andesite (59.2-60.7\% $\mathrm{SiO}_{2}$ ) lava flows from South Sister, east of Prouty Glacier, that descends $3 \mathrm{~km}$ eastward from Little Ice Age moraines to lowland apron north of Golden Lake. One thick flow banked against northwest ridge of Broken Top and was diverted southward to Green Lakes. Most exposures on apron are devitrified and block jointed to slabby or platy, but proximal outcrops through ice and till are at least partly glassy, as are sparse flow-base exposures, even on lower apron. Green Lakes lobe is largely glassy, perhaps reflecting contact with valleyfilling ice. Phenocrysts: $15-20 \%$ plag (mph to $2.5 \mathrm{~mm}$ ); $3 \%$ pyroxenes (mph to $1.5 \mathrm{~mm}$ ); minor olivine (mph to $1.5 \mathrm{~mm}$ ); sparse oxide $\mathrm{mph}$; also contains common plag-pyroxeneoxide clots. Overlies units mpm and aeg (27 $\pm 2 \mathrm{ka})$; banks against units mbt, rpc, and drm $(29 \pm 1 \mathrm{ka})$. Compositionally similar to dike of unit ahi on rim above Prouty Glacier. ${ }^{40} \mathrm{Ar} /{ }^{39} \mathrm{Ar}$ age: $23.7 \pm 1.3 \mathrm{ka}[\mathrm{BT}, \mathrm{SS}]$

Andesite west of Middle Sister (late Pleistocene) - Fan of ruggedly glaciated, moderately porphyritic andesite (59.1-60.6\% $\left.\mathrm{SiO}_{2}\right)$ lava flows on west slope of Middle Sister $(7,150$ to $8,100 \mathrm{ft}$ elevation), cropping out in seven or more separate windows through till, scree, and unit mms. Lithologically similar to nearby unit awr (just north), but slightly richer in $\mathrm{Ti}, \mathrm{Fe}, \mathrm{Mn}, \mathrm{Mg}$, and $\mathrm{Ca}$ and slightly poorer in $\mathrm{K}$ and $\mathrm{P}$. Several outcrops each expose from one to six flows, most of which retain some vitrophyre facies, but thick flows are dominated by variably devitrified internal facies, ranging from block jointed to platy. Scoriaceous and oxidized flow-breccia zones crop out widely, separating massive zones of stacked flow units. Flow thicknesses vary widely, between 2 and $50 \mathrm{~m}$. Phenocrysts: 7-10\% plag (mph to 2.5 $\mathrm{mm}$ ); $2 \%$ pyroxenes (mph to $2.2 \mathrm{~mm}$ ), mostly in common plag-pyroxene-oxide clots; sparse oxide mph. Base not exposed. Overlain by units mms and mms'; cut by dikes of unit mms and intruded and overlain by unit dlp (21 $\pm 2 \mathrm{ka})$. Undated [NS]

Andesite west of Renfrew Glacier (late Pleistocene) — Fan of several (compositionally similar) andesite $\left(60.8-61.6 \% \mathrm{SiO}_{2}\right)$ lava flows that forms northwest medial slope of Middle Sister at elevations between 6,900 and 7,900 ft. Stacks of as many as six moderately porphyritic flows are glacially eroded into several west-trending buttresses, overlapped and surrounded by till and derivative coarse alluvium. Lithologically similar to unit awm (just south) but slightly richer in $\mathrm{K}$ and $\mathrm{P}$ and slightly poorer in $\mathrm{Ti}, \mathrm{Fe}, \mathrm{Mn}, \mathrm{Mg}$, and $\mathrm{Ca}$; likewise similar to unit awc (just north) but richer in $\mathrm{Ti}, \mathrm{Fe}$, and $\mathrm{Mg}$ and slightly poorer in $\mathrm{Si}, \mathrm{Na}$, and $\mathrm{K}$. Some flows are only 2 to $5 \mathrm{~m}$ thick and largely vitrophyric, having oxidized flow-breccia zones separating them; most are 15 to $40 \mathrm{~m}$ thick, extensively devitrified, and block jointed to platy. Where flows are steep, flow foliation commonly is convolute. Phenocrysts: 5-7\% plag (mph to $2.2 \mathrm{~mm}$ ); 1-2\% pyroxenes (mph to $1.2 \mathrm{~mm}$ ); sparse oxide $\mathrm{mph}$; also contains abundant plag-pyroxene-oxide clots. Base not exposed. Overlain by unit mrg ( $20 \pm 6 \mathrm{ka})$, (inferentially) by $\mathrm{mms}$ and $\mathrm{dbh}(18 \pm 2 \mathrm{ka})$, and extensively by glacial deposits (unit $\mathrm{g}$ ). Undated [NS]

Andesite of Whychus Creek (middle Pleistocene) - Phenocryst-rich andesite (61.3-62.0\% $\mathrm{SiO}_{2}$ ) lava flow exposed along gorge floor of Whychus Creek from near confluence of its north and south forks downstream for $2 \mathrm{~km}$; remnant also banked against west wall of valley about $1 \mathrm{~km}$ still farther downstream. As thick as $25 \mathrm{~m}$ along walls of gorge, where base is not exposed and outcrops are devitrified and slabby to platy. Exposure through thick till on hill east of gorge rim and $500 \mathrm{~m}$ northeast of confluence is block-jointed black vitrophyre. Where banked against west sidewall downstream, columnar basal vitrophyre 
forms 6-m-thick ledge overlain by about $20 \mathrm{~m}$ of platy devitrified andesite (mantled by till). Phenocrysts: $10-15 \%$ plag ( $\mathrm{mph}$ to $4.5 \mathrm{~mm}$ ); $2-3 \%$ pyroxenes (mph to $1.5 \mathrm{~mm}$ ), mostly in common plag-pyroxene-oxide clots; sparse oxide mph. Base not exposed along river, but flow banks against unit mbw on west sidewall. Overlain by units bwy and mwh (195 $\pm 5 \mathrm{ka})$. Source vent unknown; most likely Broken Top. ${ }^{40} \mathrm{Ar} /{ }^{39} \mathrm{Ar}$ age: $298.7 \pm 1.4 \mathrm{ka}$ [TCB]

bac Basalt of Alder Creek (late or middle Pleistocene) - Nearly aphyric basaltic (51.2-53.1\% $\mathrm{SiO}_{2}$ ) lava that forms prominent ridge at 5,800 to $5,950 \mathrm{ft}$ elevation on north wall of Alder Creek, $6 \mathrm{~km}$ northeast of North Sister summit. Steep narrow ridge, about $400 \mathrm{~m}$ long, is nose of former glacially sculpted cleaver that separated ice streams. Rock is more pervasively altered than any recognized in map area other than in near-vent regions affected by hydrothermal or fumarolic processes. Where least altered (or merely silicified), rock is dark gray to greenish gray, massive, aphanitic, and almost aphyric. Somewhat more altered domains have medium- to coarse-grained groundmass and are diktytaxitic or exhibit angular vesicles. Most widespread lithology has coarse groundmass and extensive porosity, is locally brick red interspersed with green and yellow patches, weathers tan to yellow brown, and disintegrates to grus. Phenocrysts: $2-3 \%$ olivine (mostly mph, but rarely $0.5-1.2 \mathrm{~mm}$ ). Groundmass, which contains abundant tiny olivine, varies from finely felty, rich in plag microlites, to dense tangle of plag-lath $\mathrm{mph}$ that are seriate from 0.1 to $0.5 \mathrm{~mm}$ and include rare laths as long as $1.5 \mathrm{~mm}$. Base not exposed. Overlain by units mey and $\mathrm{mns}$. Unique exposure is stratigraphically oldest unit in its area. ${ }^{40} \mathrm{Ar} /{ }^{39} \mathrm{Ar}$ age: $128 \pm 7 \mathrm{ka}$ [TCB]

bbd Basalt of Brush Draw (late or middle Pleistocene) - Moderately porphyritic basaltic $\left(51.1-51.4 \% \mathrm{SiO}_{2}\right)$ lava flow that crops out south and east of Brush Draw at southeast toe of Trout Creek Butte. Exposed only beyond glacial limit, its surface is scoriaceous to rubbly. Source unknown, as proximal extent is wholly covered by younger lavas. Phenocrysts: $10 \%$ plag (mph to $3.5 \mathrm{~mm}) ; \sim 1 \%$ olivine $(0.2-1.5 \mathrm{~mm})$; rare cpx $(0.5-1 \mathrm{~mm})$; some plag crystals are sieved, and some are composite. Base not exposed here, but flow extends well northeast of map area. Banks around base of unit mtb shield $(532 \pm 7 \mathrm{ka})$. Overlain by unit bss. Undated [TCB] moderately porphyritic basaltic $\left(50.8-51.5 \% \mathrm{SiO}_{2}\right)$ lava flows at shoreline of large eastern embayment of Sparks Lake and extending 1 to $2 \mathrm{~km}$ east and south thereof. Source vents are north-south chain of three basaltic scoria cones (stippled on map) about $3 \mathrm{~km}$ east of lakeshore and surrounded by apron of younger lava flows from "Egan Cone" (unit mec). Northern cone is $600 \mathrm{~m}$ wide, having $115 \mathrm{~m}$ of relief on its west side, whereas middle and southern cones are $200 \mathrm{~m}$ wide and only about $30 \mathrm{~m}$ high. All three cones have small craters: middle crater contains pond, and southern crater is breached southward. All cones are dominantly lapilli and are widely oxidized, and each has scattered scoria bombs as big as 1 $\mathrm{m}$. Lava-flow surfaces are rubbly to blocky, uneroded, and pervasively vesicular. Because unit is not extensively rifted like underlying lavas of units bsl and bes, more massive interior exposures are rare. Unit forms main peninsula near Sparks Lake boat ramp and most offshore islands. Phenocrysts: $\sim 3-8 \%$ olivine $(0.2-2 \mathrm{~mm})$; sparse plag laths $(\leq 1 \mathrm{~mm}$, mostly $\mathrm{mph}$ ); sparse to abundant plag-olivine clots and intergrowths are diagnostic of unit, as are olivine clusters; cpx-plag clots are very rare. Groundmass is rich in plag-lath mph, seriate to microlites. Overlies units bsl and bes. Overlain by unit mec and local remnants of Mazama ash (7.7 ka; not mapped separately). Equivalent to parts of units "mb4" and "mb4b" of Scott and Gardner (1992). Undated [BT]

bcc Basalt of Cayuse Crater (early Holocene or latest Pleistocene) - Postglacial basaltic $\left(49.7-51.9 \% \mathrm{SiO}_{2}\right.$ ) scoria cones (stippled on map) and lava-flow apron $\left(49.7-51.9 \% \mathrm{SiO}_{2}\right)$ on southwest slope of middle Pleistocene Broken Top edifice. Fissure-fed alignment, striking northwest, built three small mounds and one substantial breached cone (having $200 \mathrm{~m}$ of downslope relief) of loose scoria and variably agglutinated spatter, widely oxidized. Two thin fountain-fed lava flows extend about $1 \mathrm{~km}$ southwest from northwestern vents. Main leveed flow fan from large breached cone divides downslope into one tongue along Fall Creek and another that extends $4 \mathrm{~km}$ to Soda Creek and alluvial floodplain at Sparks Lake. Scoriaceous rubbly flow surfaces are marked by several blocky levees, some having $10 \mathrm{~m}$ of local relief. Phenocrysts: $7 \%$ olivine (mph to $1.5 \mathrm{~mm}$ ); plag absent or limited to $\mathrm{mph}$ laths in groundmass. Overlies several glaciated lavas from Broken Top volcano and banks against Todd Lake volcanic edifice. Overlain by remnants of Mazama ash (7.7 ka) and late 
Holocene pumice-fall deposits of units rrm and rdc (not mapped separately). On nearby Broken Top edifice, scoria fall from Cayuse Crater overlies till thought to represent 13-12 ka [12.5-11 ka uncalibrated] glacial readvance of Scott and Gardner (1992); elsewhere, organic-rich sediment beneath fallout gave age of $9,520 \pm 100{ }^{14} \mathrm{C}$ yr B.P. (considered minimum age by Scott, 1987) [BT]

bes Basalt east of Sparks Lake (early Holocene or latest Pleistocene) - Phenocryst-poor basaltic (49.3-49.8\% $\mathrm{SiO}_{2}$, at $0.35-0.41 \% \mathrm{~K}_{2} \mathrm{O}$ ) lava flows just east of (but only locally along) east shore of south arm of Sparks Lake. Flow surfaces are rugged, scoriaceous, and rubbly, virtually uneroded. Like underlying unit bsl, flows are cut by several linear rifts 1 to $15 \mathrm{~m}$ wide and as deep as $5 \mathrm{~m}$ that expose prismatically jointed or block-jointed interior facies. Crude columns 0.3 to $1 \mathrm{~m}$ thick and 1 to $5 \mathrm{~m}$ long exposed on rift walls are widely marked by subhorizontal vugs, which are typically 3 to $20 \mathrm{~cm}$ long, 0.5 to $5 \mathrm{~cm}$ thick, and irregular in shape. Phenocrysts: almost aphyric, except for very rare plag megacrysts, which are typically shattered and as big as $9 \mathrm{~mm}$, and 3-5\% tiny olivine $\mathrm{mph}(0.1-0.3 \mathrm{~mm})$. Groundmass contains conspicuous plag microlites. Overlies unit bsl. Overlain by units bbr and mec and by local remnants of Mazama ash (7.7 ka). Undated [BT]

bhs Basalt south of The Husband (middle Pleistocene) - Assemblage of thin to thick basaltic $\left(51.1-53.0 \% \mathrm{SiO}_{2}\right)$ lava flows that make up glacially eroded floor and walls of Indian Holes valley at south base of The Husband. Less silicic than most lavas of The Husband (unit mth: $52-57 \% \mathrm{SiO}_{2}$ ), these basalts may represent early stage of The Husband, overlain by its main (less mafic) apron lavas. Alternatively, they may have issued from unrelated vents that later were buried, or some may have erupted at Sphinx Butte. Mapping in this area is inadequate to identify location(s) of source vent(s). Knob $6760,3 \mathrm{~km}$ north of Indian Holes, on southeast apron of The Husband, is glaciated flank vent for lavas of unit mth'; its ${ }^{40} \mathrm{Ar} /{ }^{39} \mathrm{Ar}$ age, $149 \pm 5 \mathrm{ka}$, provides minimum age for The Husband edifice itself (unit mth) and for subjacent lavas of this unit. Basalts of this unit are all phenocryst poor but include varieties that range from plagioclase free, having 3-5\% olivine ( $\mathrm{mph}$ to $1 \mathrm{~mm}$ ), to flows that have as much as $2 \%$ plag and 3\% olivine (each $0.5-1 \mathrm{~mm}$ ), with or without clots of olivine-plag mph. All or most flows carry sparse oxide mph, as well as sparse plag xenocrysts, sieved and rounded. Felty holocrystalline groundmass is dominated by plag laths, which are seriate from $\mathrm{mph}$ to microlites. Base of basalt pile is exposed downstream to west but not within map area. Overlain by units msc, ddl, and mth. Undated [SS]

bjc Basalt of James Creek (middle Pleistocene) - Vent cone and apron of phenocryst-poor olivinebasalt (51.5-51.8\% $\mathrm{SiO}_{2}$ ) lavas that extends $2 \mathrm{~km}$ west along James Creek and $2 \mathrm{~km}$ south to Mesa Creek. Glaciated Knob 6482 has 120 m of relief and consists of lava flows, agglutinate, sparse loose scoria, and 30-m-high vertically jointed lava wall on its north side that appears to partially expose a plug. Benches of dacite lava (unit ddl; $32 \pm 2 \mathrm{ka}$ ) that banked against interior facies of knob indicate that basalt was glaciated at least once prior to dacite eruption. Ice-scoured apron lavas are mostly massive and widely till strewn, showing little preservation of vesicular facies. Phenocrysts: $3-5 \%$ olivine (mph to $1 \mathrm{~mm}$ ), some in clusters and many carrying spinel inclusions; no truly phenocrystic plag, but felty holocrystalline groundmass contains plag, seriate from microlites to microphenocrystic laths, a few of which are as long as $0.5-0.7 \mathrm{~mm}$; also contains rare plag xenocrysts $(1-1.5 \mathrm{~mm})$, sieved and rounded. Overlies unit dmc. Overlain by unit ddl. ${ }^{40} \mathrm{Ar} /{ }^{39} \mathrm{Ar}$ age: $148 \pm 4 \mathrm{ka}$ [SS]

bnf Basalt of North Fork Whychus Creek (middle Pleistocene) - Four mutually isolated windows of phenocryst-rich basaltic (50.9-52.5\% $\mathrm{SiO}_{2}$ ) lava that crop out (progressively downstream) on floor of North Fork Whychus Creek, at 5,320 ft elevation, and on west rim of Whychus Creek valley, at 5,180 ft, 5,160 ft, and 5,000 ft elevations. Correlated, in part, on basis of unusually high $\mathrm{Al}_{2} \mathrm{O}_{3}$ contents (20.2-22.0\%). At streambed location, flow forms massive ledge $10 \mathrm{~m}$ thick that supports cascade; sandwiched by units mws below and msp above, its outcrop pinches out laterally within $30 \mathrm{~m}$. Middle two outcrops are glacially scoured ledges of massive, block-jointed to slabby basalt mantled with till, one of them overlain by unit msp. Downstream outcrop is lithologically similar ledge, more than $25 \mathrm{~m}$ thick, that overlies units mwh and mws and is overlain by thick till. Phenocrysts: $20-35 \%$ plag (mph to $4.5 \mathrm{~mm}$ ), blocky or elongate; $0.5-2 \%$ olivine $(0.5-3 \mathrm{~mm})$; rare cpx (1-2 $\mathrm{mm})$; many large olivine crystals are partly resorbed and unusually elongate; tiny plag, olivine, and oxide crystals of felty groundmass are not seriate with phenocrysts. Overlies units mwh (195 \pm 5 
ka) and mws ( $175 \pm 3 \mathrm{ka})$. Overlain by unit msp, which is in turn overlain by lava flow of unit mns (which here gave ${ }^{40} \mathrm{Ar}{ }^{39} \mathrm{Ar}$ age of $119 \pm 6 \mathrm{ka}$ ). Buried source vent could be far to west or southwest. Undated [TCB]

bsb Basalt of Sphinx Butte (middle Pleistocene) —Deeply eroded basaltic (51.3-52.7\% $\mathrm{SiO}_{2}$ ) edifice exposed on south wall of Mesa Creek (and possibly farther northwest at western limit of map area). Glacially eroded butte has $550 \mathrm{~m}$ of relief on its steep north face, which exposes massive plug (unit bsb') $300 \mathrm{~m}$ wide and retains thick deposits of stratified scoria and agglutinate (stippled on map) adjacent to its summit. Along Mesa Creek, apron of lava flows, which are largely massive, slabby, block jointed, or chunk jointed, supports stairstep set of small waterfalls. Phenocrysts: $2-5 \%$ olivine ( $8-10 \%$ in plug rock, unit bsb'); no truly phenocrystic plag, but felty groundmass is rich in plag-lath mph, a few of which are as long as $0.7 \mathrm{~mm}$; also contains sparse sieved plag xenocrysts as big as $1 \mathrm{~mm}$ and sparse oxide mph. Investigation of edifice only cursory; contact where unit banks against lavas of The Wife (unit mtw; $374 \pm 6 \mathrm{ka}$ ) was mapped by Wozniak (1982). Overlain by unit ddl ( $32 \pm 2 \mathrm{ka}$ ). ${ }^{40} \mathrm{Ar} /{ }^{39} \mathrm{Ar}$ age: $279 \pm 6 \mathrm{ka}$ [SS]

bsI Basalt southeast of Sparks Lake (early Holocene or latest Pleistocene) —Phenocryst-poor basaltic $\left(51.1 \% \mathrm{SiO}_{2}\right.$, at $\left.0.56 \% \mathrm{~K}_{2} \mathrm{O}\right)$ lava flows exposed along east shore of south arm of Sparks Lake; lowest of four distinguishable sets of lava flows that make up extensive postglacial apron east of lake. Source vent unknown, apparently buried by younger mafic lavas. Flow surfaces are rugged, scoriaceous, and rubbly. Block-jointed or columnar interior is widely exposed where large cracks have opened near lakeshore flow margin, creating several rifts 1 to $5 \mathrm{~m}$ deep and 1 to $15 \mathrm{~m}$ wide. Phenocrysts: $3-5 \%$ olivine $(0.5-2 \mathrm{~mm})$; sparse plag (mostly mph, but rare crystals to $2 \mathrm{~mm}$ ). Groundmass commonly finely diktytaxitic and rich in plag-lath mph. Base not exposed. Overlain by associated postglacial units bes and bbr and by local remnants of Mazama ash (7.7 ka). Equivalent to part of unit "mb4" of Scott and Gardner (1992) and Gardner (1994). Undated [BT]

bss Basalt of Spruce Spring (late Pleistocene) - Apron of thin basaltic (50.0-50.4\% $\mathrm{SiO}_{2}$, at $0.6-0.7 \% \mathrm{~K}_{2} \mathrm{O}$ ) lava flows just southeast of Trout Creek Butte that emerges from beneath distal limit of late Pleistocene moraines and extends $4 \mathrm{~km}$ farther east (between Pole Creek and Brush Draw) to terminus just beyond edge of map area. Unglaciated surface is scoriaceous, rubbly, and locally block jointed, especially on levees. Phenocrysts: $2-3 \%$ olivine $(0.5-1 \mathrm{~mm}$, very rarely to $4 \mathrm{~mm})$; at least $5 \%$ olivine $\mathrm{mph}(0.2-0.4 \mathrm{~mm}) ; 1 \%$ plag phenocrysts $(0.5-2 \mathrm{~mm}$ ), but $\sim 30 \%$ plag $\mathrm{mph}$ in holocrystalline plag-lath groundmass. Coarsegrained groundmass has abundant plag $\mathrm{mph}$ and microlites, as well as diktytaxitic porosity that has scattered 1-mm-wide equant vesicles superimposed. Normal magnetic polarity (Taylor, 1987). Overlies units bbd, acp, and mwh (195 $\pm 5 \mathrm{ka})$, wraps around scoria cone of unit acp, and banks against base of unit mtb shield (532 $\pm 7 \mathrm{ka})$. Overlain and proximally concealed by late Pleistocene till (unit g); source vent probably far to west. Undated [TCB]

btk

Basalt and basaltic andesite of Talapus and Katsuk Buttes (latest Pleistocene) - Compound edifice of basaltic $\left(51.7-53.4 \% \mathrm{SiO}_{2}\right)$ lavas, hyaloclastite, and scoria cones that form west wall of Sparks Lake. Elongate edifice, only 1.5 to $2.5 \mathrm{~km}$ wide, extends $6 \mathrm{~km}$ north-south and has $225 \mathrm{~m}$ of relief. Chain of vents near north end, probably dike fed, includes two substantial subaerial scoria cones (stippled on map). In its northern part, lower $140 \mathrm{~m}$ of edifice is interpreted as hyaloclastite tuff by Scott and Gardner (1992) that may have erupted through its own meltwater pond within latest Pleistocene recessional ice. Plateau above is capped by stacks of thin subaerial lava flows from several vents. Basal contact of subaerial deposits descends southward, almost to base of edifice at its south end (possibly reflecting southward slope of ice surface at time of eruption). Fragmental deposits are locally palagonitized. Slumps of more coherent rimrock lavas include rotated megablocks 10 to $200 \mathrm{~m}$ long (Scott and Gardner, 1992), as well as chaotic rubble. Large area of slumps west of Katsuk Butte was overrun by lava flows of unit mlc, itself of latest Pleistocene age, suggesting that slumping took place soon after deglaciation. Phenocrysts: $\sim 5 \%$ olivine $(0.2-2 \mathrm{~mm}$, mostly $0.5-1 \mathrm{~mm}$ ); abundant plag consists mostly of microphenocrystic laths (or clusters thereof), but some lavas contain sparse plag laths $0.5-1.2 \mathrm{~mm}$ long, and olivine-plag clots are common. Southwest edge of Katsuk Butte overlies unit dse, and stratified ejecta of Talapus Butte (stippled on map) overlie unit rdh ( $34.8 \pm 1.5 \mathrm{ka})$ on slope north of Devils Lake. Overlain by units mlc and rdc. Undated [BT, SS] 
bwl Basalt of lower Whychus Creek (late or middle Pleistocene)-Phenocryst-poor basaltic $\left(50.8 \% \mathrm{SiO}_{2}\right)$ lava flow exposed at 4,150 to $4,220 \mathrm{ft}$ elevation on north wall of Whychus Creek near east edge of map area. Deeply eroded flow is block jointed but locally still scoriaceous and rubbly on its surface, which lies barely outside belt of moraine deposits. Source vent unknown, presumably far upstream. Downstream extent beyond map area not determined. Phenocrysts: sparse plag $(0.5-2.5 \mathrm{~mm})$, but abundant groundmass plag-lath $\mathrm{mph}$, seriate to microlites; $5-7 \%$ olivine (mph to $1.3 \mathrm{~mm}$ ), seriate to groundmass olivine. Overlies unit mwh (195 $\pm 5 \mathrm{ka})$. Overlain by unit acp. Undated [TCB]

bwm Basalt west of Millican Crater (late Pleistocene) - Glaciated aprons of olivine-rich basaltic (48.6-50.6\% $\mathrm{SiO}_{2}$ ) lava flows that crop out widely on both sides of north-trending fissurefed ridge of unit mpn, which probably conceals their vent. East apron slopes gently southeast for $2 \mathrm{~km}$, overlapping west toe of Millican Crater edifice (unit $\mathrm{mmc}$ ). West apron slopes northwest for more than $2 \mathrm{~km}$, extending at least as far as Lava Camp Lake $(1.2 \mathrm{~km}$ north of edge of map area). Most exposures are slightly vesicular but otherwise are massive and block jointed, forming numerous ledges (1-3 m high), knolls, and ice-scoured swells. Window through moraine just south of east apron exposes two ledge-forming lava flows for about 100 m (UTM grid 992/988). Another window, through unit myl about $1.5 \mathrm{~km}$ farther southeast, is block-jointed ledge only about $1 \mathrm{~m}$ high and $50 \mathrm{~m}$ across (UTM grid 010/981). Phenocrysts: moderate variations in plag and olivine abundances among lava flows; $3-10 \%$ olivine (mph to $1.5 \mathrm{~mm}$, rarely $2.5 \mathrm{~mm}) ; 0-5 \%$ plag $(0.5-2 \mathrm{~mm}$, rarely as long as $3.5 \mathrm{~mm}$ ), many subhedral; clots of olivine+plag mph and clusters of olivine $\mathrm{mph}$ are as big as $10 \mathrm{~mm}$ and generally are sparse but in some flows are abundant. Groundmass is rich in plag-lath mph and microlites. Overlies unit mmc. Overlain by units mpn, myc, myl, and (inferentially) mnt (20 $\pm 5 \mathrm{ka})$. Undated [NS, TCB]

bwy Basalt of Whychus Creek (middle Pleistocene)-Two windows of phenocryst-poor basalt (51.1-51.8\% $\mathrm{SiO}_{2}$ ): one is at 5,120 to $5,160 \mathrm{ft}$ elevation just downstream from Upper Chush Falls; other is $2 \mathrm{~km}$ north at about 4,800 ft on lowermost North Fork Whychus Creek. Although slightly different chemically, both are nearly aphyric and unlike any other rare basalts in this area. Exposures about $500 \mathrm{~m}$ downstream from Upper Chush Falls include 10-m-high ledge (slabby to block jointed), which supports a small waterfall at 5,140 ft elevation on Whychus Creek, and knife-edge point at nearby confluence of Park Creek. On North Fork Whychus Creek, coarsely block jointed rimrock ledge more than $15 \mathrm{~m}$ thick supports cascades; its basal flow breccia and massive lava flow drape andesite of unit awy and old till sandwiched between them on right-bank wall. Phenocrysts: almost none; holocrystalline groundmass microlites are seriate to $\sim 3 \%$ olivine mph $(0.2-0.4 \mathrm{~mm})$ and $<1 \%$ plag laths (0.2-0.7 mm long); most mph are in olivine-plag-oxide clots. Overlies units mbt and awy (299 $\pm 1 \mathrm{ka})$. Overlain by units adl, drm, mwh (195 $\pm 5 \mathrm{ka})$, and ruc $(169 \pm 2 \mathrm{ka})$. Undated [TCB]

dbh Dacite of "Black Hump" (late Pleistocene) — Glaciated pile of effusive dacite (64.0-64.5\% $\mathrm{SiO}_{2}$ ) lava flows that erupted at vent in saddle between North Sister and Middle Sister. Compact ice-sculpted edifice, variously called "Black Hump" (Hodge, 1925), "Prouty Point," or "Step Sister," is about $1 \mathrm{~km}$ across, consists of at least five flow units, and has 325 $\mathrm{m}$ of relief, including several cliffy faces. In addition, two of these thick flows extend separately for about $1 \mathrm{~km}$ west and northwest of proximal pile as narrow arêtes. Another flow crops out atop medial cleaver in Collier Glacier. Individual flows range in thickness from 25 to $90 \mathrm{~m}$. Lithologies vary from black vitrophyre, locally columnar, to pale-gray devitrified felsite, block jointed or slabby to platy, commonly having oxidized scoriaceous rubbly zones between flows. Phenocrysts: $7-10 \%$ plag (mph to $4 \mathrm{~mm}$, rarely larger); $1-2 \%$ opx (mph to $2 \mathrm{~mm}$, rarely to $3.5 \mathrm{~mm}$ ); sparse oxide $\mathrm{mph}$; contains common plag-pyroxene-oxide clots, which account for most pyroxene crystals. Overlies units awc $(22 \pm 2 \mathrm{ka})$, dss (25 $\pm 3 \mathrm{ka})$, and mms. Relations with unit dhr at col are obscured by scree. ${ }^{40} \mathrm{Ar} /{ }^{39} \mathrm{Ar}$ ages: $17.9 \pm 2.2 \mathrm{ka}$ (for western lava flow), $23 \pm 7 \mathrm{ka}$ (for base of pile north of Hayden Glacier) [NS]

$\mathrm{dbl} \quad$ Dacite breccia of Lewis Glacier headwall (late Pleistocene) - Crudely stratified, pale-gray- to tan-weathering, fragmental dacite $\left(62.6-62.8 \% \mathrm{SiO}_{2}\right)$ deposit as thick as $50 \mathrm{~m}$ that banks against paleocrater wall above Lewis Glacier and directly underlies unit dlg. Clasts are monolithologic, glassy, dense or weakly vesicular, subangular to subrounded, and as big as $20 \mathrm{~cm}$ throughout most of section but as large as $1 \mathrm{~m}$ near top; matrix is seriate from ash to 
lapilli-sized clasts. Clasts are slightly less silicic than overlying lava flow of unit dlg and contain twice as many plag phenocrysts. Strata are subhorizontal to slightly inboard dipping in headwall exposures, but craggy remnants preserved outboard of wall (atop eroded rim of wall-forming unit adh dome) dip steeply outboard. Phenocrysts: $15 \%$ plag (mph to $3 \mathrm{~mm}$ ); $<1 \%$ pyroxenes (mostly $\mathrm{mph}$ ), largely in clots with plag. Top $2 \mathrm{~m}$ of unit is baked brick red, contrasting starkly with black, glassy horizontal columns of overlying lava flow of unit dlg (25.3 $\pm 1.4 \mathrm{ka}, 22.3 \pm 1.6 \mathrm{ka})$. Undated [SS]

dcg Dacite southwest of Clark Glacier (late Pleistocene) - Southwest apron of South Sister edifice, consisting of many compositionally uniform dacite $\left(63.0-63.5 \% \mathrm{SiO}_{2} ; \mathrm{n}=26\right)$ lava flows. Stairstep stack of flows, each 15 to $100 \mathrm{~m}$ thick, forms glaciated 3 by $3 \mathrm{~km}$ surface that extends from Clark Glacier to toe of edifice at Hinton and Mesa Creeks. Lithologies vary from black vitrophyre, commonly chunk jointed or columnar, to devitrified and block jointed or slabby to platy. Flow foliation is commonly conspicuous and locally convolute in thickest flows. Scoriaceous rubbly oxidized zones are common between flows. High on apron, steep and thick eruptive masses have internal shear zones of oxidized breccia intimately alternating with vitrophyric and platy domains, perhaps reflecting influence of snow and ice. Phenocrysts: $10-20 \%$ plag (mph to $4 \mathrm{~mm}$ ); $1-3 \%$ pyroxenes (mostly $\mathrm{mph}$, but as big as $1 \mathrm{~mm}$ ); sparse oxide $\mathrm{mph}$; abundant plag-pyroxene-oxide clots; most pyroxene and half of plag crystals reside in clots. Overlies units bjc, ddl ( $32 \pm 2 \mathrm{ka})$, rmc (47 $\pm 8 \mathrm{ka})$, and rsw $(51 \pm 10 \mathrm{ka})$. Overlain by unit aeg (here, $27 \pm 2 \mathrm{ka})$ and also by units rct $(24 \pm 5 \mathrm{ka}, 30 \pm 8$ $\mathrm{ka})$ and $\mathrm{rrm}(\sim 2.1 \mathrm{ka})$, which bank against it. ${ }^{40} \mathrm{Ar} /{ }^{39} \mathrm{Ar}$ age: $30.7 \pm 2.6 \mathrm{ka}[\mathrm{SS}]$

dcl Dacite of Chambers Lakes (late Pleistocene) - Agglutinated tephra fallout and rheomorphic dacite (64.8-65.9\% $\mathrm{SiO}_{2} ; \mathrm{n}=13$ ) lava flows, widely exposed in saddle between Middle Sister and South Sister. Principal outcrop forms glacially eroded ridge about $1 \mathrm{~km}$ wide that separates two clusters of Chambers Lakes. Relief exposed exceeds $110 \mathrm{~m}$, but true thickness is less if ridge-forming agglutinate drapes unexposed units. Deposit is crudely stratified or lensoid, eroded into ledges; variable dips as steep as $25^{\circ}$ suggest buried paleotopography. Main lithology is orange and black streaky vitrophyre that grades from densely eutaxitic to tack welded and, locally, to loose pumice and scoriae (as big as $40 \mathrm{~cm}$ ), which can be black, dark brown, or tan but mostly are oxidized orange. Fiamme vary from tiny wisps to as long as $50 \mathrm{~cm}$ and as thick as $15 \mathrm{~cm}$. Lithic clasts include phenocryst-poor mafic lavas but are predominantly pyroxene andesite-dacite, mostly smaller than $10 \mathrm{~cm}$ but some as large as $50 \mathrm{~cm}$. Source probably is glacially excavated bowl now occupied by largest lake, adjacent to which juvenile and lithic clasts are both largest. On ridgecrest, least viscous agglutinate sections spread southward and eastward as rheomorphic flows that range in texture from blobby to massive and virtually homogenized; they grade up and down into eutaxite. Where glacially beveled, such flows range internally from densely glassy to devitrified and platy. Phenocrysts: $3-7 \%$ plag, varying widely in clasts of similar composition; most plag ranges in size from mph to $2.5 \mathrm{~mm}$, rarely $3-6 \mathrm{~mm} ; 0.5-2 \%$ pyroxenes (mostly mph, but sparse grains $0.5-1.5 \mathrm{~mm}$ ); common oxide $\mathrm{mph}$; some but not most plag crystals are sieved internally; also common are plag-pyroxene-oxide clots, which account for most pyroxene crystals. Overlies unit aeg ( $27 \pm 3 \mathrm{ka})$, but base is rarely exposed. Overlain by units $\mathrm{mcl}$, $\mathrm{mms}$, and dig (14 $\pm 3 \mathrm{ka})$, as well as pumice-fall remnants of unit rdc. ${ }^{40} \mathrm{Ar} /{ }^{39} \mathrm{Ar}$ age: $26 \pm 2 \mathrm{ka}$ [NS, SS]

den Dacite north of Carver Lake (late Pleistocene) - Sequence of two or three glacially scoured dacite (66.9-67.4\% $\mathrm{SiO}_{2}$ ) lava flows exposed in windows through Neoglacial till between Carver Lake and Chambers Lakes; all dip northward from buried vent on South Sister edifice, summit of which lies only $2 \mathrm{~km}$ south. Lavas are vesicular and glassy or partly devitrified, as well as block jointed and having densely vitrophyric bases that locally are chunk jointed. Phenocrysts: $\sim 10 \%$ plag (mph to $4 \mathrm{~mm}$, rarely $6 \mathrm{~mm}$ ); $1-2 \%$ pyroxenes (mph to 2 $\mathrm{mm}$ ); sparse oxide mph. Base not exposed. Apparently (not certainly) overlain by unit aeg (here, $27 \pm 2 \mathrm{ka}$ ). Undated [SS]

ddl Dacite of Dew Lake (late Pleistocene)—Thick, glacially scoured, phenocryst-poor dacitic (64.1-64.4\% $\mathrm{SiO}_{2}$ ) lava flows that extend $4 \mathrm{~km}$ westward between Separation and Mesa Creeks from beneath southwest apron (unit dcg) of South Sister edifice. Flows tightly wrap vent knob of unit bjc, around which they divide into two tongues. Proximal area exposes as much as $50 \mathrm{~m}$ of local relief, and distal cliffs are as high as $80 \mathrm{~m}$ in both tongues. Lithology 
varies from massive black vitrophyre, commonly chunk jointed or columnar, to pale gray, devitrified, and slabby or platy. Phenocrysts: $2-3 \%$ plag (mph to $1.5 \mathrm{~mm}$, rarely $3 \mathrm{~mm}$ ); $0.5-1 \%$ pyroxenes (nearly all $\mathrm{mph}$, but rarely as large as $0.8 \mathrm{~mm}$ ); sparse oxide $\mathrm{mph}$; also contains common plag-pyroxene-oxide clots. Overlies units $\mathrm{mtw}$, bsb, bhs, and bjc. Overlain by units dcg $(30.7 \pm 2.6 \mathrm{ka})$ and $\mathrm{msc}(21 \pm 6 \mathrm{ka}) .{ }^{40} \mathrm{Ar} /{ }^{39} \mathrm{Ar}$ age: $32.3 \pm 1.8 \mathrm{ka}$ [SS]

des Dacite ejecta of South Sister summit (late Pleistocene) - Stratified dacitic (62.8-64.2\% $\mathrm{SiO}_{2}$; $\mathrm{n}=14$ ) fall and surge deposit, ultraproximal, largely phreatomagmatic, that makes up much of uppermost 120 to $150 \mathrm{~m}$ of summit cone of South Sister. Coarse fragmental deposit crops out best above Prouty Glacier headwall east and northeast of summit but also is exposed above Lewis Glacier headwall to southeast and on crater rim west of Teardrop Pool; it is overlain only by dacitic lava flows locally along north rim of summit (units dnt, dnt') and by thin andesitic agglutinate (unit mtp, topmost eruptive unit that extensively drapes summit). Much of unit banks inside ragged rim of (locally breached) outer paleocrater wall that consists of unit aeg; it rests on intracrater lava dlg and fills paleocrater to unknown depth. Thickest exposed section, on steep slope above Prouty Glacier headwall consists conspicuously of four subunits (not mapped separately):

1. Lowest $10 \mathrm{~m}$ is coarsely lithic rich, unstratified to crudely stratified section, poor in juvenile clasts, that dips $10^{\circ}$ to $25^{\circ}$ outboard; its poorly exposed base rests on unit dlg. Lithic clasts, mostly $1-40 \mathrm{~cm}$ across, rarely as big as $100 \mathrm{~cm}$, are angular fragments of underlying unit dlg, most of them hydrothermally altered. Subordinate juvenile dacite material is limited largely to lapilli and finer fractions.

2. Overlying subunit 1 , about $30 \mathrm{~m}$ of section contrasts in being predominantly juvenile, lithic poor, and well stratified. Its basal $50 \mathrm{~cm}$ is sharply bounded, pale-gray interval dominated by juvenile dacite that is glassy, angular, slightly to moderately vesicular, and seriate from ash to $20 \mathrm{~cm}$ blocks; this layer banks against and drapes a 5-m-long block of prismatically jointed dacite that rests atop subunit 1 and may represent initiation of dome disruption that followed episode of vent excavation. Nearly all of this subunit consists of thin-bedded to laminated, lithic-poor strata, typically in coherent bedsets 10 to $30 \mathrm{~cm}$ thick, that also dip $10^{\circ}$ to $25^{\circ}$ outboard, like section beneath. Far more thinly stratified than other subunits, its layering is defined by coarse-to-fine alternations on subcentimeter scale. Most clasts are only 0.5 to $2 \mathrm{~cm}$ across, although sparse clasts are as big as $20 \mathrm{~cm}$; all are glassy and angular, some are prismatically jointed, and vesicularity varies from fine to poor.

3. Middle 25 to $30 \mathrm{~m}$ is coarsest part of section, marked by three very coarse layers, each 4 to $10 \mathrm{~m}$ thick, separated by wavy-bedded intervals 1 to $3 \mathrm{~m}$ thick; strata dip $15^{\circ}$ to $20^{\circ}$ inboard and overlie unconformity that smoothly bevels underlying outward-dipping strata. Clasts are massive or poorly vesicular, glassy, angular, matrix-supported, and monolithologic crystal-rich dacite; many are 5 to $50 \mathrm{~cm}$ across, and some are prismatically jointed; matrix is crystal-rich coarse ash, seriate to small lapilli. Basal few meters of bedded middle section is disrupted by several small faults.

4. Upper $75 \mathrm{~m}$ is stratified only crudely and dips gently inboard, conformable with coarse middle part of section. As in subunit 3 beneath it, clasts are massive or poorly vesicular, glassy, angular, matrix supported, and monolithologic; most clasts are only 0.5 to $2 \mathrm{~cm}$ across, although scattered coarser $(5$ to $15 \mathrm{~cm}$ ) clasts in lenses or vague horizons help define crude layering. Matrix consists of crystal-rich coarse ash, seriate to small lapilli. Within continuous $145-\mathrm{m}$-thick section of four subunits, no sedimentary intervals are observed that might represent prolonged breaks in eruption. Wavy and contorted beds and bomb sags are common. Accidental lithic fragments are sparse except in basal $10 \mathrm{~m}$, where angular and altered dacite lithic fragments $(0.5-40 \mathrm{~cm}$ across, some to $100 \mathrm{~cm})$ are abundant, and all or most are derived from underlying unit dlg. Phenocrysts in juvenile clasts: $15-20 \%$ plag (mph to $3 \mathrm{~mm}$ ); $2-3 \%$ pyroxenes ( $\mathrm{mph}$ to $1 \mathrm{~mm}$ ); sparse oxide $\mathrm{mph}$; also contains common plag-pyroxene-oxide clots as big as $5 \mathrm{~mm}$, which account for most pyroxene crystals. Overlies units aeg (here, $27 \pm 3 \mathrm{ka})$ and dlg $(25.3 \pm 1.4 \mathrm{ka}, 22.3 \pm 1.6 \mathrm{ka})$. Overlain by units $\mathrm{mtp}$, dnt (23.5 $\pm 1.1 \mathrm{ka})$, and dnt'. Undated [SS]

dgc Dacite of Goose Creek (late Pleistocene) - Glaciated dacite (64.8-65.3\% $\left.\mathrm{SiO}_{2}\right)$ lava flow that extends $3.5 \mathrm{~km}$ southward from southeast toe of South Sister to alluvial plain north of Sparks Lake. Maximum relief about $75 \mathrm{~m}$ proximally and medially, but only $35 \mathrm{~m}$ at distal terminus. Source vent buried by younger units. Ranges in lithology from black vitrophyre 
to devitrified, block jointed or slabby to platy. Locally preserved are glassy margins that have vertical, horizontal, and inclined slender columns, suggestive of ice contact. Normal magnetic polarity (Taylor, 1978). Phenocrysts: $5-7 \%$ plag (mph to $3 \mathrm{~mm}$ ); $1-2 \%$ pyroxenes (mostly $\mathrm{mph}$, rarely as big as $1 \mathrm{~mm}$ ); sparse oxide $\mathrm{mph}$; also contains common plagpyroxene-oxide clots. Intruded and overlain by unit rdc; appears to underlie eroded ridge

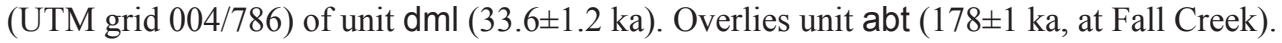
${ }^{40} \mathrm{Ar} /{ }^{39} \mathrm{Ar}$ age: $31.6 \pm 2.0 \mathrm{ka}[\mathrm{BT}]$

dgl Dacite of Green Lakes (late Pleistocene) - East-southeast apron of South Sister edifice, consisting of many phenocryst-rich dacite $\left(62.9-64.2 \% \mathrm{SiO}_{2}\right)$ lava flows. Glacially scoured unit forms most of edifice flank on north side of trough draining Lewis Glacier, extending from beneath Hodge Crest planèze (unit aeg) down to Green Lakes basin. Total elevation difference exposed within unit is $600 \mathrm{~m}$, but greatest local relief (and, thus, maximum thickness exposed) is only $130 \mathrm{~m}$ (on scarp just west of Green Lakes). Consists of 12 or more flows that range in thickness from about $15 \mathrm{~m}$ to 60 to $80 \mathrm{~m}$, thicker ones being strongly flow foliated. Flows range in lithology from dark-gray vitrophyre to devitrified, block jointed, or slabby to platy, weathering tan or pale gray. Phenocrysts: $5-10 \%$ plag (mph to $3 \mathrm{~mm}$ ); $1-3 \%$ pyroxenes $(0.2-1 \mathrm{~mm})$; sparse oxide $\mathrm{mph}$; also contains common plag-pyroxene-oxide clots, which account for most pyroxene crystals. Overlies unit rgl (32 $\pm 1 \mathrm{ka})$. Overlain by units dmn (28 $\pm 1 \mathrm{ka}, 25 \pm 1 \mathrm{ka})$ and aeg (here, $27 \pm 2 \mathrm{ka})$. Undated [BT, SS]

dhr Dacite of Hayden Glacier-Renfrew Glacier col (late Pleistocene) - Single dacite (63.6-64.3\% $\mathrm{SiO}_{2}$ ) lava flow, 15 to $20 \mathrm{~m}$ thick, that drapes north ridge of Middle Sister cone from 9,600 $\mathrm{ft}$ elevation down to 9,200-ft-high saddle between Hayden and Renfrew Glaciers. Vent is presumed to have been slightly east on part of edifice since removed by Hayden Glacier. Surface of flow is extensively vesicular, oxidized pink, or laced with secondary minerals that lend outcrops an orange cast. Exposures of flow interior are flow foliated, partly glassy, massive or vesicular, block jointed, or locally devitrified and platy. Phenocrysts: $\sim 10 \%$ plag (mph to $5 \mathrm{~mm}$ ); 2\% pyroxenes (mph to $2 \mathrm{~mm}$, rarely $3 \mathrm{~mm}$ ); sparse oxide $\mathrm{mph}$; also contains abundant plag-pyroxene-oxide clots. Rests unconformably directly on smoothly beveled stack of flows of unit mms. Relations with adjacent unit dbh obscured by scree that fills col. ${ }^{40} \mathrm{Ar} /{ }^{39} \mathrm{Ar}$ age: $19.1 \pm 1.7 \mathrm{ka}$ [NS]

dig Dacite of Irving Glacier (latest Pleistocene) - Dacite (64.1-64.2\% $\mathrm{SiO}_{2}$ ) coulee from inconspicuous vent at 8,500 ft elevation on south slope of Middle Sister. Proximal to medial reach is leveed, unglaciated, and 150 to $400 \mathrm{~m}$ wide. Distally, it bifurcates around rhyolite lava dome of unit rsc; southwest arm ends $3 \mathrm{~km}$ from vent in 100-m-high, glacially modified cliff above Separation Creek; southeast arm ends $2 \mathrm{~km}$ from vent in 135-m-high cliff, where flow banked against ice that had ponded in basin now occupied by Chambers Lakes, as shown by glassy subhorizontal columns widely preserved on flow front. Latest Pleistocene ice encountered by both arms probably still flowed down to saddle from high on South Sister when south slope of Middle Sister was ice free. Thick vitrophyre zones form upper and lower parts of flows, whereas central parts of terminal cliffs include devitrified internal zones exposed by glacial erosion. Vent area is 50-m-wide depression enclosed by blocky sidewall levees 10 to $15 \mathrm{~m}$ high and upslope headwall consisting of stack of thin mafic lava flows of older unit $\mathrm{mms}$, which was oxidized brownish orange by dacite eruption. Airborne ejecta are sparse; glassy angular blocks, some prismatically jointed, are strewn about depression, but most tumbled in from levees. Inner east wall of depression is tack-welded to densely agglutinated spatter. Levees adjacent to vent are capped by oxidized flow breccia and locally by agglutinate, but elsewhere levees are composed of black glassy blocks of unoxidized dacite, mostly massive but some having scoriaceous surfaces. Films of secondary minerals coat joints in near-vent dacite and, more conspicuously, in mafic rubble of headwall. Phenocrysts: $5-10 \%$ plag (mph to $3.5 \mathrm{~mm}$, rarely to $8 \mathrm{~mm}$ ); $1-2 \%$ pyroxenes (mph to $1.5 \mathrm{~mm}$ ); sparse oxide $\mathrm{mph}$; also contains common plag-pyroxene-oxide clots; limited thin-section data suggest greater abundance of plag and pyroxene mph in proximal levees than in distal lava lobes. Overlies units mms, rsc $(25 \pm 1 \mathrm{ka}), \mathrm{dcl}(26 \pm 2 \mathrm{ka})$, and dsn $(19 \pm 4 \mathrm{ka}) .{ }^{40} \mathrm{Ar}{ }^{39} \mathrm{Ar}$ age: $14.4 \pm 2.7 \mathrm{ka}[\mathrm{NS}, \mathrm{SS}]$

dkb Dacite of Kokostick Butte (late Pleistocene) - Phenocryst-rich dacite (62.5-63.1\% $\mathrm{SiO}_{2}$ ) coulee and chain of small satellite domes 2 to $5 \mathrm{~km}$ south of Rock Mesa. Coulee is $2 \mathrm{~km}$ long and $1 \mathrm{~km}$ wide, having maximum relief of 100 to $150 \mathrm{~m}$ at its southern flow front, from which springs emerge as source of Sink Creek. Chain of five satellite domelets extends $1.8 \mathrm{~km}$ 
south-southwest from main coulee, to which they are compositionally identical; domelets range in height from 30 to $90 \mathrm{~m}$ and in width from 130 to $300 \mathrm{~m}$. Coulee and domelets are glacially scoured but have little till on top; all are widely glassy and retain extensive outcrops of slender exterior columns, which are commonly inclined or subhorizontal, suggestive of ice-contact effusion. Where most deeply eroded by ice, steep faces of coulee and two largest satellites expose partly devitrified, vertically jointed to slabby interiors. Phenocrysts: $15-20 \%$ plag (mph to $3 \mathrm{~mm}$ ); $2-3 \%$ pyroxenes (mostly $\mathrm{mph}$, but as big as $1 \mathrm{~mm}$ ); sparse oxide mph; also contains abundant plag-pyroxene-oxide clots, which account for most pyroxene crystals. Southern domelets intrude and overlie apron of mafic lava flows (unit $\mathrm{mkm}$ ) from Koosah Mountain. Mafic lava flows of postglacial unit mlc wrap coulee and two domelets. ${ }^{40} \mathrm{Ar} /{ }^{39} \mathrm{Ar}$ age of coulee: $27.3 \pm 2.6 \mathrm{ka}$ [SS]

dlc Dacite of Linton Creek (late Pleistocene) - Window of glaciated dacite $\left(66.8 \% \mathrm{SiO}_{2}\right)$ lava that has $70 \mathrm{~m}$ of steep relief, exposed only in 100 by $300 \mathrm{~m}$ area at about $5,800 \mathrm{ft}$ elevation in headwaters of middle fork of Linton Creek, just above Pacific Crest Trail (UTM grid 946/876). Glassy, finely vesicular, flow-foliated, chunk-jointed zone below is overlain by platy devitrified zone near top of exposure. Phenocrysts: $5-8 \%$ plag (mostly $\mathrm{mph}$, but as long as $1.7 \mathrm{~mm}$ ); 1\% pyroxenes (mph to $1.5 \mathrm{~mm}$ ); sparse oxide $\mathrm{mph}$; also contains common plag-pyroxene-oxide clots, which account for most pyroxene crystals. Base not exposed. Overlain by units ahl, alc ( $27 \pm 1 \mathrm{ka}), \mathrm{mhl}$, and $\mathrm{mms}$. Undated [NS]

dlg Dacite of Lewis Glacier headwall (late Pleistocene) - Thick dacite (63.5-63.8\% $\mathrm{SiO}_{2}$ ) lava flow near summit of South Sister that crops out as bold cliffs high on headwalls above Lewis and Prouty Glaciers. Convolutely foliated flow is 75 to $100 \mathrm{~m}$ thick and banks against ragged wall of paleocrater that consists of units aeg, ahc, adh, and alh, as exposed on both headwalls. Vitrophyre and partly devitrified upper zone overlie cliff-forming devitrified internal zones, block jointed or slabby, exposed above glaciers. Basal zones exposed in both headwalls exhibit subhorizontal columns as thin as $8 \mathrm{~cm}$; vertical fractures cutting columns impart hackly appearance. Overlies fragmental deposit of unit dbl in Lewis Glacier headwall and another older fragmental deposit (unit ahc) in Prouty Glacier headwall; lava of this unit baked both underlying units. Overlain by 150 -m-thick section of phenocryst richer fragmental dacite strata (unit des). Another glaciated dacite $\left(63.7-64.4 \% \mathrm{SiO}_{2}\right)$ lava flow as thick as $60 \mathrm{~m}$, which crops out $2 \mathrm{~km}$ north of summit (and $600 \mathrm{~m}$ lower), is correlated chemically and petrographically and here also assigned to this unit. Flow is widely devitrified and platy, although locally glassy, block jointed, or brecciated; it weathers pale gray or tan, and its exposure extends about $1 \mathrm{~km}$ northward along west side of steep gulch draining into eastern cluster of Chambers Lakes. Base of flow is not exposed; flow is directly overlain by rhyolitic lava flow of late Holocene unit rdc and is apparently intruded by its feeder dike. Phenocrysts: $3-5 \%$ plag (mph to $2 \mathrm{~mm}$ ); $1-2 \%$ pyroxenes (mostly mph, but including rare crystals $1-2.5 \mathrm{~mm}$ ); sparse oxide $\mathrm{mph}$; also contains common plag-pyroxene-oxide clots, which account for most pyroxene crystals. Overlies or banks against units aeg (here, $27 \pm 3 \mathrm{ka})$, adh, ahc, alh $(30 \pm 1 \mathrm{ka})$, and dbl. Overlain by units des and rdc. ${ }^{40} \mathrm{Ar} /{ }^{39} \mathrm{Ar}$ ages: $25.3 \pm 1.4 \mathrm{ka}, 22.3 \pm 1.6 \mathrm{ka}[\mathrm{SS}]$

dlp Dacite of Lane Plateau (late Pleistocene)—Sandal-shaped dacite (64.2-65.3\% $\mathrm{SiO}_{2}$ ) coulee and glacially eroded remnant of narrow lava stream that fed it from vent at 7,800 ft elevation on west slope of Middle Sister. Coulee, 2 by $1 \mathrm{~km}$ in area and having $90 \mathrm{~m}$ of relief distally, forms steep-sided ice-scoured plateau that slopes gently westward between Linton and Obsidian Creeks. Remnant of feeding flow forms 800-m-long steep ridge about 150 $\mathrm{m}$ wide that has as much as $40 \mathrm{~m}$ of local relief; segments formerly connecting it to both vent and coulee have been eroded away. Extrusive vent mass, $2.2 \mathrm{~km}$ east of main coulee and $425 \mathrm{~m}$ higher in elevation, is unusual protrusion $150 \mathrm{~m}$ long and 20 to $50 \mathrm{~m}$ thick that stands as wall-like monument about $25 \mathrm{~m}$ high. Steep downhill face of wall is largely glassy and widely retains horizontal polygonal joints, including long slender radial and inclined columns at its upper edge, suggesting that extrusion took place into ice. Near-vertical joints crop out at base of wall where dacite welled out over (and baked) andesite lava of unit awm. Both coulee and feeder ridge are lithologically varied, widely exhibiting vitrophyric exterior facies (locally columnar) but slabby to platy devitrified interior facies where more deeply eroded. Phenocrysts: $5-7 \%$ plag ( $\mathrm{mph}$ to $3 \mathrm{~mm}$, rarely to $8 \mathrm{~mm}$ ); $2-3 \%$ pyroxenes (mph to 1 $\mathrm{mm}$, rarely to $2 \mathrm{~mm}$ ); sparse oxide $\mathrm{mph}$; also contains common plag-pyroxene-oxide clots; 
limited thin-section data suggest that phenocryst abundance of near-vent lava is roughly half that of medial and distal lava. Overlies units aoc, alc (here, $27 \pm 1 \mathrm{ka}$ ), ahl (21 $\pm 3 \mathrm{ka})$, and awm. Younger units mms and mms' bank against uphill wall of vent mass. ${ }^{40} \mathrm{Ar} /{ }^{39} \mathrm{Ar}$ age: $21.4 \pm 1.9 \mathrm{ka}[\mathrm{NS}]$

dmc Dacite of Mesa Creek (middle Pleistocene) - Poorly exposed window of glaciated dacite $\left(65.1 \% \mathrm{SiO}_{2}\right)$ lava that forms north slope of Mesa Creek, 0.5 to $1.5 \mathrm{~km}$ west of Rock Mesa. South-sloping surface has about $60 \mathrm{~m}$ of total relief; pink and gray exposures exhibit strong flow foliation, locally platy. Source vent, concealed by younger units, probably is buried beneath much younger South Sister edifice. Phenocrysts: 7\% plag (mph to $1.3 \mathrm{~mm}$ ); $\sim 2 \%$ pyroxenes (nearly all $\mathrm{mph}$, rarely as long as $1 \mathrm{~mm}$ ); sparse oxide $\mathrm{mph}$; contains common

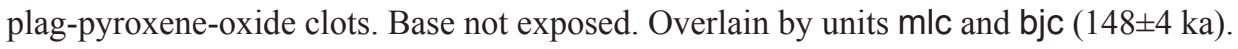
Undated [SS]

$\mathrm{dml}$ Dacite southeast of Moraine Lake (late Pleistocene) - Glaciated stack of phenocryst-rich dacite $\left(64.0-65.7 \% \mathrm{SiO}_{2}\right)$ lava flows north of Devils Hill that extends $2 \mathrm{~km}$ southeast from Moraine Lake to Goose Creek. One flow extends $1 \mathrm{~km}$ southwest, where its snout emerges from beneath younger coulee of unit dmw. Main pile south and east of Moraine Lake has as much as $140 \mathrm{~m}$ of relief and consists of at least four flows, all heavily mantled by proximal pumice-fall deposits of units rrm and rdc. Moraine Lake has no moraine; valley-crossing ridge above its south shore is spur of glaciated lava of this unit, thickly mantled by pumice and discontinuous subordinate veneer of glacial debris. Distal crags, severely ice sculpted at Goose Creek, have about $100 \mathrm{~m}$ of relief. External vitrophyre facies are widely preserved on stairstep ledges, whereas shelves and plateaus, more deeply scoured, tend to expose internal devitrified zones, commonly platy. On steep ledge banked against Devils Hill and on westfacing scarp south of Moraine Lake, slender glassy columns (commonly inclined or subhorizontal) are widespread, suggesting ice-contact emplacement. Compositionally similar to underlying unit dwp and overlying unit dmw. Phenocrysts: $5-10 \%$ plag (mph to $3 \mathrm{~mm}$ ); $\sim 1 \%$ pyroxenes (nearly all $\mathrm{mph}$, rarely as big as $0.8 \mathrm{~mm}$ ); sparse oxide $\mathrm{mph}$; also contains common plag-pyroxene-oxide clots, which account for most pyroxene crystals. Overlies unit dwp ( $34 \pm 3 \mathrm{ka})$; appears to overlie unit dgc $(32 \pm 2 \mathrm{ka})$, but relation is uncertain. Banks

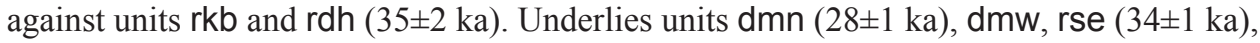
and rdc. ${ }^{40} \mathrm{Ar} /{ }^{39} \mathrm{Ar}$ age: $33.6 \pm 1.2 \mathrm{ka}$ [BT, SS]

dmn Dacite north of Moraine Lake (late Pleistocene) - Glacially scoured dacite (65.1-66.3\% $\mathrm{SiO}_{2}$ ) lava flows on south slope of South Sister; exposed as high as 8,840 ft elevation at snout of Lewis Glacier, extending $3 \mathrm{~km}$ south, nearly to Moraine Lake, in two (compositionally identical) tongues, each a single flow. Thickness as much as $80 \mathrm{~m}$, proximally, medially, and distally. Source vent probably central on South Sister, now covered by unit aeg and other younger units. Vitrophyre facies are patchily preserved and typically block jointed, but most exposures are devitrified (or partly so) and either block jointed or platy. Phenocrysts: 5-7\% plag (mph to $3 \mathrm{~mm}$ ); $1-2 \%$ pyroxenes (mostly mph, sparsely $0.5-1.5 \mathrm{~mm}$ ); sparse oxide and olivine mph; clots of plag+pyroxenes+oxides are common, accounting for most pyroxene crystals. Overlies units dgl, dml (33.6 $\pm 1.2 \mathrm{ka}), \mathrm{dmw}$, and rse $(34 \pm 1 \mathrm{ka})$. Overlain by units aeg (here, $27 \pm 2 \mathrm{ka}$ ), als, and rct $(24 \pm 5 \mathrm{ka}) \cdot{ }^{40} \mathrm{Ar} /{ }^{39} \mathrm{Ar}$ ages: $27.7 \pm 1.0 \mathrm{ka}$ (west tongue), $25.2 \pm 0.8 \mathrm{ka}$ (east tongue) [SS]

dms Dacite of Middle Sister summit (late Pleistocene) - Glassy, phenocryst-poor dacite $\left(63.9-66.7 \% \mathrm{SiO}_{2}\right)$ lava flow that drapes upper southeast ridge of Middle Sister, extending from within $30 \mathrm{~m}$ (south) of true summit (10,047 ft elevation) downslope for about 350 $\mathrm{m}$ to $9,420 \mathrm{ft}$ elevation. Small outlier $80 \mathrm{~m}$ farther down ridgecrest and another just north of summit suggest that much more was eroded away. Main remnant is 100 to $200 \mathrm{~m}$ wide across ridgeline and 10 to $20 \mathrm{~m}$ thick; its ragged southwest contact reflects instability of subjacent thin rubbly flows of unit $\mathrm{mms}$ on steep slope. Blocky surface is frost riven but was not overridden by glacial ice. Eroded mass of possible vent plug cuts unit mms below east rim in precipitous chute about $100 \mathrm{~m}$ southeast of true summit. Black glassy blocks are generally massive, rarely vesicular or partly devitrified. Greenish-black, finely vesicular, phenocryst-poor pumice lapilli sparsely scattered among blocks on ridgecrest are compositionally similar. Phenocrysts: $2-3 \%$ plag (mph to $1.5 \mathrm{~mm}$ ); 1\% pyroxenes (nearly all $\mathrm{mph}$, rarely as big as $1 \mathrm{~mm}$ ); sparse oxide mph. Rests directly on unweathered surface of unit $\mathrm{mms}$. Unit mss banks against northern remnant. Undated [NS] 
dmw Dacite coulee west of Moraine Lake (late Pleistocene) - Glacially scoured, steep-sided dacite $\left(64.6-65.5 \% \mathrm{SiO}_{2}\right)$ lava flow at south toe of South Sister. Flow emerges from beneath younger lavas on lower slope of edifice and extends $3 \mathrm{~km}$ southward where it banks against unit $\mathrm{dml}$ at north side of Kaleetan Butte. Flow is 0.5 to $1 \mathrm{~km}$ wide, about $60 \mathrm{~m}$ thick distally, and 90 to $120 \mathrm{~m}$ thick medially, adjacent to Moraine Lake. Phenocryst-rich dacite is widely flow foliated. Devitrified interior, block jointed to platy, is widely exposed, but vitrophyric margins (dense or locally vesicular) are also extensively preserved, including widespread chunk jointing and slender columns, inclined or subhorizontal, indicative of ice-contact emplacement. Rusty films common on joint surfaces. Phenocrysts: $10-15 \%$ plag (mph to 3 $\mathrm{mm}$ ); $1-2 \%$ pyroxenes (mostly $\mathrm{mph}$, but as large as $0.8 \mathrm{~mm}$ ); also contains abundant plagpyroxene-oxide clots, which account for nearly all oxide mph present. Proximal part of flow also has trace hornblende ( $\mathrm{mph}$ to $1 \mathrm{~mm}$ long), all grains of which are marginally or fully opacitized. Overlies units $\mathrm{dml}(33.6 \pm 1.2 \mathrm{ka})$ and dwp ( $34 \pm 3 \mathrm{ka})$. Overlain by lithologically similar unit dmn $(28 \pm 1 \mathrm{ka})$ and by unit rct $(24 \pm 5 \mathrm{ka})$. Undated [SS]

dnt Dacite north of Teardrop Pool (late Pleistocene) - Block-jointed and fractured, glassy, phenocryst-rich dacite $\left(62.7-63.1 \% \mathrm{SiO}_{2}\right)$ lavas that directly cap compositionally similar fragmental unit des for about $200 \mathrm{~m}$ along northwest rim of South Sister summit. Sandwiched between unit des and summit-mantling agglutinate unit mtp, total lava thickness is 8 to $10 \mathrm{~m}$ near rim. Outboard of rim, lavas extend about $100 \mathrm{~m}$ downslope in three overlapping fingerlike lobes that drape steep slope of fragmental unit des; blocky lobes are marked by joint-coating films of white and orange precipitates. Phenocrysts: $10 \%$ plag; $2-3 \%$ pyroxenes; also contains common plag-pyroxene clots. ${ }^{40} \mathrm{Ar} /{ }^{39} \mathrm{Ar}$ age: $23.5 \pm 1.1 \mathrm{ka}[\mathrm{SS}]$

dnt' Silicic dacite north of Teardrop Pool (late Pleistocene) - Massive glassy ledge of phenocrystrich dacite $\left(67.1 \% \mathrm{SiO}_{2}\right)$ on north rim of South Sister summit; petrographically similar to, but far more silicic than, dacite lavas of unit dnt, only about $100 \mathrm{~m}$ west. Ledge is only 30 to $50 \mathrm{~cm}$ thick and crops out laterally for only about $15 \mathrm{~m}$. Films of white and orange precipitates are present on smooth joints and on its upper surface. Phenocrysts: 7-10\% plag (mph to $3 \mathrm{~mm}$ ); $2-3 \%$ pyroxenes ( $\mathrm{mph}$ to $0.7 \mathrm{~mm}$ ); sparse oxide $\mathrm{mph}$; also contains common plag-pyroxene-oxide clots. Sandwiched between top of unit des and summit agglutinate unit $\mathrm{mtp}$, ledge is in same stratigraphic position as unit dnt but represents anomalously silicic effusion, presumably of small volume. No evidence is preserved in outcrop or thin section for welding or pyroclastic texture, but origin as rheomorphically homogenized agglutinate seems likely. Undated but presumed to be virtually contemporaneous with unit dnt [SS]

dpg Dacite pumice fall of Prouty Glacier headwall (late Pleistocene)-Dacite $\left(64.6 \% \mathrm{SiO}_{2}\right)$ scoria-fall deposit, pale gray to buff weathering, 5 to $20 \mathrm{~m}$ thick, exposed on steep headwall above Prouty Glacier. Crudely stratified in lower half, moderately so in upper half, having nearly horizontal layering. Unit consists predominantly of phenocryst-poor scoria lapilli, mostly 1 to $2 \mathrm{~cm}$ but as big as $20 \mathrm{~cm}$, and it lacks fine-grained matrix. Pale-gray lithic ejecta as big as $10 \mathrm{~cm}$, principally of intermediate lava, are common near base. Most small scoriae are buff, although some are dark brown or mixed; larger scoriae are dark brown or gray internally but typically retain buff exterior; all are glassy and finely to coarsely vesicular. Stratification in basal several meters at south end of exposure is accentuated by alignment of elongate (slightly flattened), large dark clasts. Phenocrysts: $\sim 1 \%$ plag (mph to 1 -mm-long laths); $<1 \%$ pyroxenes (all $\mathrm{mph}$ ); sparse oxide $\mathrm{mph}$; sparse fine-grained clots of plag+pyroxenes+oxides. Rests directly upon lava of unit rpg (32.8 $\pm 1.5 \mathrm{ka})$ and unit aph'. Overlain unconformably by tephra-fall deposit of unit ahc and by layered scoria, agglutinate, and fountain-fed lavas of cone-building andesite unit aeg (here, $27 \pm 3 \mathrm{ka}$ ). Undated but compositionally and petrographically similar to lava of unit ddl ( $32 \pm 2 \mathrm{ka}$ ) on opposite side of South Sister [SS]

drm Dacite of Red Meadow (late Pleistocene) - Extensive set of glacially scoured dacite $\left(62.6-66.3 \% \mathrm{SiO}_{2} ; \mathrm{n}=20\right)$ lava flows on northeast apron of South Sister. Emerging from beneath Neoglacial moraines of Prouty Glacier, ledgy stack of several 10- to 20-m-thick flows condenses medially to two thick flows, one of which continues $6 \mathrm{~km}$ northeast, forming broad divide between Whychus and Park Creeks. Where two flows are exposed locally (see internal contact near UTM grid 024/877), unit is as wide as $2 \mathrm{~km}$ medially, and surface is extensively mantled by Pleistocene till. Thickness is as great as $150 \mathrm{~m}$ medially and at least $60 \mathrm{~m}$ near distal terminus. Despite having been everywhere overrun by Pleistocene ice, 
unit widely retains vitrophyric external facies, including flow-margin carapace of slender black inclined columns facing Red Meadow, suggesting emplacement against valley glacier. In many patches, however, erosion has exposed devitrified internal facies, partly to fully devitrified and commonly slabby to platy. Phenocrysts: $10-15 \%$ plag (mph to $3 \mathrm{~mm}$ ); $1-2 \%$ pyroxenes (mostly $\mathrm{mph}$, but as large as $1.5 \mathrm{~mm}$ ); sparse oxide $\mathrm{mph}$; also contains abundant plag-pyroxene-oxide clots, which account for most pyroxene crystals. Nearly all plag is clean and unsieved; rare sieved plag crystal observed is apparent xenocryst attached to $1.5 \mathrm{~mm}$ olivine that has reaction rim. Overlies units apc (31 $\pm 9 \mathrm{ka}), \mathrm{rpc}, \mathrm{rpg}(32.8 \pm 1.5 \mathrm{ka})$, and bwy; wraps around snout of unit rsf coulee ( $36 \pm 2 \mathrm{ka})$. Overlain by units adl ( $24 \pm 1 \mathrm{ka})$, awf $(24 \pm 1 \mathrm{ka})$, and, proximally, aeg (here, $27 \pm 3 \mathrm{ka}) .{ }^{40} \mathrm{Ar} /{ }^{39} \mathrm{Ar}$ age: $28.7 \pm 0.8 \mathrm{ka}$ [BT, SS, TCB]

dse Dacite east of Sink Creek (late or middle Pleistocene) - Phenocryst-poor dacite (66.2\% $\mathrm{SiO}_{2}$ ) lava flow forming 200-m-wide glaciated shelf that crops out for about $800 \mathrm{~m}$ beneath southwestern margin of Katsuk Butte. Ledge front has about $25 \mathrm{~m}$ of relief. Mantled by surficial deposits, unit is poorly exposed, consisting mostly of angular blocks of massive flow-foliated dacite. Phenocrysts: almost none; very rare plag $(0.5-2 \mathrm{~mm})$; very rare cpx $\mathrm{mph}$ prisms. Groundmass contains sparse quench needles of flow-aligned oxides and plag (mostly microlites, but rarely as big as 0.1 by $1 \mathrm{~mm}$ ). Base not exposed. Overlain by unit btk. Postglacial lava flows of unit mlc bank against unit. Undated [SS]

dsn Dacite north of Separation Creek (late Pleistocene) - Glacially scoured flow of moderately porphyritic dacite $\left(64.3-64.4 \% \mathrm{SiO}_{2}\right)$ lava between headwaters forks of Separation and Linton Creeks. Forming barren plateau $(0.5$ by $1 \mathrm{~km})$ of extraordinarily platy lava at about $6,850 \mathrm{ft}$ elevation, flow has maximum exposed relief of about $40 \mathrm{~m}$ near its western limit. Source vent buried beneath younger units of Middle Sister edifice; composition is remarkably similar to that of overlying coulee of unit dig, which also erupted on Middle Sister. Thick flow is almost horizontal, having probably ponded at lowland toe of edifice. Massive vitrophyric lower zone is exposed along marginal drainages, but most of extensive outcrop is devitrified and platy, commonly splitting into plates only 0.5 to $1 \mathrm{~cm}$ thick. Phenocrysts: $2-5 \%$ plag (mph to $3 \mathrm{~mm}$ ); $<1 \%$ pyroxenes (nearly all $\mathrm{mph}$, but rarely $0.5-1 \mathrm{~mm}$ ); sparse oxide $\mathrm{mph}$; also contains common plag-pyroxene-oxide clots, which account for most pyroxene crystals. Base not exposed. Overlain by units $\mathrm{mms}$ and $\operatorname{dig}(14 \pm 3 \mathrm{ka}) .{ }^{40} \mathrm{Ar}{ }^{39} \mathrm{Ar}$ age: $19 \pm 4$ ka [NS, SS]

dss Dacite of Sister Spring (late Pleistocene) - Glacially scoured dacite (63.6-63.7\% $\mathrm{SiO}_{2}$ ) lava flow at northwest toe of Middle Sister edifice, directly overlying coulee of the rhyolite of Obsidian Cliffs (unit roc). Depressions on barren plateau surface contain several ponds, including "Arrowhead Lake." Thickest exposure is northwest scarp, 60 to $80 \mathrm{~m}$ high, from base of which Sister Spring emerges. Most outcrops are devitrified and very platy, though patchy remnants of vitrophyre remain on plateau surface. Phenocrysts: $5 \%$ plag (mph to $2.5 \mathrm{~mm}$ ); $\sim 1 \%$ pyroxenes (mostly $\mathrm{mph}$, rarely as big as $0.5 \mathrm{~mm}$ ); sparse oxide $\mathrm{mph}$; also contains common plag-pyroxene-oxide clots. Overlies unit mlb ( $48 \mathrm{ka})$; also overlies unit roc ( $38 \pm 2 \mathrm{ka})$, draping several lithologic zones of rhyolite. Overlain by units awc $(22 \pm 2 \mathrm{ka})$, $\mathrm{mms}$, and $\mathrm{mrg}(20 \pm 6 \mathrm{ka}) .{ }^{40} \mathrm{Ar} /{ }^{39} \mathrm{Ar}$ age: $25 \pm 3 \mathrm{ka}[\mathrm{NS}]$

dsw Dacite domes southwest of Middle Sister (late Pleistocene) - Three small dacite (65.4-65.5\% $\mathrm{SiO}_{2}$ ) lava domes, identical in composition, low on southwest slope of Middle Sister. Two western domes, which are contiguous, are $500 \mathrm{~m}$ and $400 \mathrm{~m}$ in diameter, and each has about $90 \mathrm{~m}$ of maximum relief. Smaller dome, $500 \mathrm{~m}$ east, has only $50 \mathrm{~m}$ of relief and is $150 \mathrm{~m}$ wide. Line transecting three vents strikes N. $70^{\circ}$ E., unlike any other such alignment in region. Although all were lightly scoured by ice, glassy carapace is widely preserved, varying from densely vitrophyric to micropumiceous. Outward-directed polygonal jointing and slender columns (locally horizontal) are retained in glassy exterior facies of all three domes, suggesting possibility of extrusion through ice. Limited exposures of devitrified, blockjointed to slabby felsite were found atop eastern and central domes. Phenocrysts: $7-10 \%$ plag (mph to $4.5 \mathrm{~mm}$ ); 1\% pyroxenes (mostly $\mathrm{mph}$, but sparsely $0.5-1.7 \mathrm{~mm}$ ); sparse oxide $\mathrm{mph}$; also contains common plag-pyroxene-oxide clots. Extruded through and onto Middle Sister apron of unit mms lavas. ${ }^{40} \mathrm{Ar} /{ }^{39} \mathrm{Ar}$ age: $17 \pm 15 \mathrm{ka}[\mathrm{NS}]$

dtl Dacite of Todd Lake (middle Pleistocene) - Multiflow edifice of glaciated dacitic (62.6-65.0\% $\mathrm{SiO}_{2}$ ) lavas at southeastern margin of map area, between Sparks and Todd Lakes, at south 
toe of Broken Top volcano. Edifice is elongate northeast, is $3.5 \mathrm{~km}$ long, covers about $4 \mathrm{~km}^{2}$, and has $475 \mathrm{~m}$ of relief on its southwest slope. Extensively till-mantled, eroded lavas flows are block jointed or slabby to platy. All or most flows are phenocryst rich. Phenocrysts: $7-10 \%$ plag $(0.5-3 \mathrm{~mm}) ; 1-2 \%$ each of opx, cpx, and Fe-Ti oxides. Petrographic summary given by Taylor (1978), who also determined normal paleomagnetic polarity for several lava flows and described plug just north of summit. Overlies unit mbl. Holocene unit mec banks against west toe of edifice, and (according to Taylor, 1978) middle Pleistocene mafic and andesitic lavas from Broken Top bank against north toe. Whole-rock K-Ar age of $460 \pm 30 \mathrm{ka}$ was given by Hill (1991) [BT]

dwl Dacite west of Lost Creek Glacier (late Pleistocene) - Stairstep pair of thick dacite (63.1, $64.6 \% \mathrm{SiO}_{2}$ ) lava flows that form steep glaciated buttresses on west slope of South Sister, 0.8 to $1.1 \mathrm{~km}$ west of upper Lost Creek Glacier. Lower flow forms dark-gray-weathering cliff, $40 \mathrm{~m}$ high, that has extensive exposures of flow-foliated devitrified lava that splits platy. Upper flow, more silicic, is as thick as $75 \mathrm{~m}$ and generally is glassier and irregularly jointed or block jointed, although devitrified slabby zones also are exposed. Both cliffforming flows have low-relief benches on top. Phenocrysts: 10-15\% plag (mph to $4 \mathrm{~mm}$ ); $1-3 \%$ pyroxenes ( $\mathrm{mph}$ to $1.5 \mathrm{~mm}$ ); sparse oxide $\mathrm{mph}$; both flows also contain abundant plag-pyroxene-oxide clots, which account for most pyroxene crystals; upper flow is rich in pale-gray, finely vesicular, fine-grained enclaves, mostly $1-2 \mathrm{~cm}$, that contain mph of plag and pyroxene. Overlies unit alg ( $27 \pm 1 \mathrm{ka})$. Overlain by stack of numerous thin lavas of cone-building unit aeg (here, $27 \pm 3 \mathrm{ka}$ ). Undated [SS]

dwp Dacite of Wickiup Plain (late Pleistocene) - Glacially scoured dacite (64.0-64.5\% $\left.\mathrm{SiO}_{2}\right)$ lava flow beneath southeastern margin of Rock Mesa (unit rrm). Exposed in several windows through thick pumice-fall deposit of unit rrm. More than $50 \mathrm{~m}$ of relief is exposed distally; 35-m-high crag along flow margin at Wickiup Plain retains slender glassy columns, horizontal and inclined, that suggest ice-contact emplacement. Sparse scattered exposures along surface of largely pumice-buried flow are either vitrophyric and polygonally jointed or devitrified and slabby to platy. Flow continues south beneath unit rkb and crops out further at south toe of Kaleetan Butte, where it is likewise variously glassy or devitrified and locally oxidized. Phenocrysts: $10-15 \%$ plag (mph to $4.5 \mathrm{~mm}$ ); $1-2 \%$ pyroxenes (mostly mph, rarely $0.5-1 \mathrm{~mm}$ ); sparse oxide $\mathrm{mph}$; also contains common plag-pyroxene-oxide clots. Base not exposed. Overlain by units rct ( $24 \pm 5 \mathrm{ka}), \mathrm{rkb}, \mathrm{rrm}, \mathrm{dml}(33.6 \pm 1.2 \mathrm{ka})$, and dmw, and its snout is wrapped by postglacial unit mlc. Like adjacent dacite lavas, flow probably vented well up on South Sister edifice; if so, it would also extend north beneath unit dcg ( $31 \pm 3 \mathrm{ka})$, but lowland trough between them is covered entirely by Rock Mesa pumice deposits (unit rrm). ${ }^{40} \mathrm{Ar} /{ }^{39} \mathrm{Ar}$ age: $34 \pm 3 \mathrm{ka}[\mathrm{SS}]$

mbc Basaltic andesite of Black Crater (late or middle Pleistocene) — Large mafic (55-57\% $\mathrm{SiO}_{2}$ ) lava and scoria cone, situated mostly north of map area (fig. 2). Cone is $3 \mathrm{~km}$ in diameter, has $900 \mathrm{~m}$ of relief, and produced lava-flow apron that extends 4 to $5 \mathrm{~km}$ north and northeast of summit. Stratified proximal agglutinate, scoria, and fountain-fed lava flows dip radially away from central microdiorite plug. Lower slopes were glacially scoured, and two supposed "craters" on north and east are actually glacial cirques. Lavas exposed at north edge of map area are massive, less commonly vesicular, and glacially eroded into series of blockjointed or irregularly jointed ledges. Phenocrysts: $0.5-3 \%$ plag $(0.5-1 \mathrm{~mm}) ; \sim 1 \%$ olivine (mph to $1 \mathrm{~mm}$, rarely to $2.5 \mathrm{~mm}$, locally in clusters); trace amounts of cpx. Overlain by unit mmc. Normal paleomagnetic polarity (Taylor, 1987). Undated [TCB]

$\mathrm{mbl}$ Basaltic andesite of Bare Lake (middle Pleistocene) - Sparsely to moderately porphyritic mafic (54.8-57.2\% $\left.\mathrm{SiO}_{2}\right)$ lava flows and ejecta exposed in two areas beneath south slopes of Todd Lake dacitic edifice (unit dtl). Western exposure forms steep glaciated nose that has $140 \mathrm{~m}$ of relief; eastern exposure has $250 \mathrm{~m}$ of relief, much of it cliff forming. Consists of several ledgy flows, block jointed or slabby to thinly platy; thickest flow, which forms 80-m-high southeast cliff above "Todd Creek," has steep curviplanar joint sheets that disintegrate into slabby talus. Fissure vent, which is marked by stratified scoria and agglutinate, trends north for $400 \mathrm{~m}$ along ridgecrest northwest of Bare Lake. Roadcuts in western outcrop expose brick-red scoria-fall deposit, loose to variably agglutinated and 3 to $10 \mathrm{~m}$ thick, underlying lava ledge into which agglutinate grades; fallout consists mostly of lapilli but also includes bombs as big as $25 \mathrm{~cm}$, suggesting likelihood of second vent (concealed) 
closer than fissure vent $2 \mathrm{~km}$ east. Phenocrysts: most flows have $1-2 \%$ plag $(0.5-1 \mathrm{~mm})$ and sparse olivine and cpx (each 0.1-0.4 mm); cliffy flow facing "Todd Creek" contains $\sim 8 \%$ plag (1-4 mm), common $1 \mathrm{~mm}$ olivine, and sparse cpx. Lavas also carry abundant finegrained inclusions, $0.5-6 \mathrm{~cm}$ across, that contain opx, cpx, and plag phenocrysts and, thus, may be dacitic xenoliths. Tiny glaciated nubbin beside highway $100 \mathrm{~m}$ southeast of "Todd Creek" (UTM grid 051/744) is outlier of phenocryst-poor cpx-olivine-plag lava that carries same inclusions. Lavas bank against dome of pyroxene-plag rhyodacite (unit rtl; 69.5\% $\mathrm{SiO}_{2}$ ) southwest of Todd Lake, according to Taylor (1978), who also reported that unit mbl

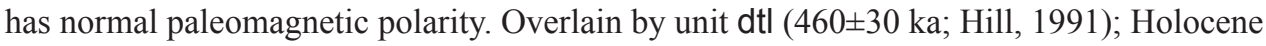
unit mec banks against toes of both exposures. Undated [BT]

mbt Basaltic andesite of Broken Top (middle Pleistocene) - Catch-all assemblage of varied and undifferentiated mafic lava flows, all thought to have erupted at or near Broken Top volcano. Generally mapped only around fringes of Broken Top apron, essentially to define boundary of present map area. Broken Top volcano has not yet been studied in detail, but its apron lavas, crater walls, and central intrusion are predominantly basaltic andesite. Our reconnaissance and that of Taylor (1978) and Webster (1992) indicate that andesite, dacite, and rhyodacite are subordinate and that edifice was built between roughly $300 \mathrm{ka}$ and $150 \mathrm{ka}$. Lavas lumped in this map unit range in texture from phenocryst poor to phenocryst rich and in composition from $52.5 \%$ to $57.8 \% \mathrm{SiO}_{2}(\mathrm{n}=28)$; all contain plag (seldom bigger than $3 \mathrm{~mm}$ ) in excess of olivine ( $\mathrm{mph}$ to $1 \mathrm{~mm}$, rarely to $2 \mathrm{~mm}$ ) and typically subordinate cpx $(0.5-1 \mathrm{~mm})$; sparse oxide $\mathrm{mph}$ are present in some samples, but not all. Older than most contiguous units described herein except for a few intercalated Broken Top andesite-dacite lavas east of Fall Creek that are assigned to comparable catch-all andesitic unit abt [BT, TCB]

mbw Basaltic andesite of Whychus Creek bridge (middle Pleistocene) - Four limited exposures of phenocryst-rich mafic $\left(52.9 \% \mathrm{SiO}_{2}\right)$ lava flows, which crop out as windows through till in bed of Whychus Creek near bridge at 4,400 ft elevation on U.S. Forest Service Road 1514 and on noses of ridges just southwest and northeast of there. Glaciated ledges are block jointed and massive or sparsely vesicular. Phenocrysts: $20 \%$ plag (mph to $4 \mathrm{~mm}$ ); $3-5 \%$ olivine ( $\mathrm{mph}$ to $2 \mathrm{~mm}$ ); rare cpx. May have erupted at or near Broken Top. Base not exposed. Overlain by units awy $(299 \pm 1 \mathrm{ka})$ and mwh $(195 \pm 5 \mathrm{ka})$. Undated [TCB]

$\mathrm{mcl}$ Basaltic andesite of Camp Lake (late Pleistocene) - Apron of phenocryst-poor mafic $\left(56.3-56.8 \% \mathrm{SiO}_{2}\right)$ lava flows that extends from its glacially eroded vent complex at about $7,700 \mathrm{ft}$ elevation on southeast flank of Middle Sister for $4 \mathrm{~km}$ eastward between North and South Forks, Whychus Creek. Vent area is ice-ravaged scoria-cone remnant (stippled on map) exposed in 600-m-wide window through lavas of unit mms. Scoria deposit is crudely stratified, mostly coarse ejecta but locally is well-bedded ash and lapilli. Bombs are as big as $1 \mathrm{~m}$, and deformed spatter blobs are as long as $2 \mathrm{~m}$ and as thick as $30 \mathrm{~cm}$. Deposit varies from loose to moderately agglutinated and is mostly brick red but locally black, and its exposed thickness is as great as $25 \mathrm{~m}$; base is not exposed. Where capped by coeruptive lava flows or cut by dikes of unit mms or overlain by lavas of unit $\mathrm{mms}$, scoria deposit is further oxidized and fused near contacts. Central lava mass, 60 by $100 \mathrm{~m}$ wide and 15 to $20 \mathrm{~m}$ thick, is massive, largely devitrified, and block jointed, except that its basal 2 to $3 \mathrm{~m}$ is platy. This platy jointing dips radially inward, as does bedding in subjacent scoria. If it is manifestation of plug, effusing lava must have flared radially outward, such that all its contacts dip moderately, and no steep contacts or steep flow foliation are exposed. Outflow lavas are eroded into stairstep benches, cliffs, and pond-filled hollows. Many exposures are 60 to $90 \mathrm{~m}$ thick, and distal cliff at South Fork Whychus Creek (UTM grid 022/882) is $120 \mathrm{~m}$ high; unit consists of several flows, individually 10 to $30 \mathrm{~m}$ thick. Black, glassy, chunk-jointed zones are exposed locally, but most outcrops are devitrified and block jointed to platy. Phenocrysts: $1-3 \%$ plag (mph to $1 \mathrm{~mm}$ ); $\leq 1 \%$ olivine (mph, rarely $0.5-1 \mathrm{~mm}$ ); very sparse oxide $\mathrm{mph}$; many plag phenocrysts are in clusters, which less commonly also include olivine and oxide $\mathrm{mph}$. Groundmass typically is rich in plag microlites, which are in some samples seriate to plag mph. Overlies units adl ( $24 \pm 1 \mathrm{ka}), \mathrm{mdl}, \mathrm{mnf}$, and msf; fills relief cut into unit dcl (26 $\pm 2 \mathrm{ka}$ ) just northeast of largest of Chambers Lakes (UTM grid 983/868); banks against toe of unit rsf coulee $(35.8 \pm 2 \mathrm{ka})$. Overlain by units $\mathrm{mms}$ ' and $\mathrm{mms}$; cut by dikes of unit mms. ${ }^{40} \mathrm{Ar} /{ }^{39} \mathrm{Ar}$ ages: $16 \pm 10 \mathrm{ka}, 23 \pm 16 \mathrm{ka}[\mathrm{NS}, \mathrm{TCB}]$ 
mdl

mey

mfy

Basaltic andesite north and south of Demaris Lake (middle Pleistocene) - Glacially eroded, cpx-bearing mafic (53.0-53.6\% $\mathrm{SiO}_{2}$ ) lava flow exposed in two windows through younger lavas, each about $500 \mathrm{~m}$ away (to south and to north) from Demaris Lake. Compositionally similar but not identical, they may be different flows. Southern outcrop $\left(53.0 \% \mathrm{SiO}_{2}\right)$ is single flow more than $60 \mathrm{~m}$ thick, block jointed to slabby, that forms east-facing cliff. Northern outcrop, which is more subdued, has ice-scoured, block-jointed ribs of modest relief. Phenocrysts: $7-10 \%$ plag (mph to $2.5 \mathrm{~mm}$ ); 1\% olivine (mph to $1.5 \mathrm{~mm}$ ); sparse $1 \mathrm{~mm}$ cpx, found principally within three-phase clots; clusters of plag crystals also common. Base not exposed but probably lies atop nearby unit msf, which is here extensively till covered. Overlain by units $\mathrm{mcl}$, adl, and rsf. ${ }^{40} \mathrm{Ar} /{ }^{39} \mathrm{Ar}$ age: $181 \pm 21 \mathrm{ka}$ (southern window) $[\mathrm{TCB}]$

Basaltic andesite west of Dutchman Flat (late or middle Pleistocene) - Glaciated mafic $\left(56.8 \% \mathrm{SiO}_{2}\right)$ scoria cone, forming Hill 6485 at north edge of Mount Bachelor Ski Area carpark. Cone is $75 \mathrm{~m}$ high and 350 by $500 \mathrm{~m}$ wide, and it consists of stratified brick-red scoria and agglutinate, mantled with glacial deposits. Phenocrysts: common plag; sparse olivine. Wrapped on west by early Holocene lava flows of unit mec and on east by postglacial lavas of Mount Bachelor (Scott and Gardner, 1992). Undated [BT]

Basaltic andesite and basalt of "Egan Cone" (early Holocene) - Postglacial basaltic $\left(50.7-52.2 \% \mathrm{SiO}_{2}\right)$ scoria cone (stippled on map) at southeast edge of map area (at north toe of Mount Bachelor) and extensive apron of mafic (51.2-54.1\% $\mathrm{SiO}_{2}$ ) lava flows that extends $2 \mathrm{~km}$ north and $4.5 \mathrm{~km}$ west and northwest to Sparks Lake (which it helped to impound). Flows are rugged, scoriaceous, rubbly, commonly leveed, and little eroded. Breached scoria cone, which is $800 \mathrm{~m}$ wide and $200 \mathrm{~m}$ high, consists of brick-red scoria lapilli and bombs. Phenocrysts: almost none; common olivine and plag mph $(0.1-0.5 \mathrm{~mm})$; uncommon $\mathrm{mph}$ clusters of olivine or olivine+plag; rare plag megacrysts (as big as $6 \mathrm{~mm}$ and typically shattered). Groundmass rich in plag-lath $\mathrm{mph}$ (rarely as long as $0.7 \mathrm{~mm}$ ), seriate to microlites; plag microlites appear to be increasingly abundant distally. Overlies unit bbr and postglacial lavas of Mount Bachelor; banks against units dtl, mbl, mdw, mts, and rtl. Primary scoriafall deposit just east of "Egan Cone" is virtually unweathered where overlain directly by Mazama ash (7.7 ka), suggesting that unit is only slightly older (Scott and Gardner, 1992). Also overlain by late Holocene pumice falls of units rrm and rdc. Equivalent to unit "mb6" of Scott and Gardner (1992), youngest unit of entire 25-km-long Mount Bachelor volcanic chain. Undated [BT]

Basaltic andesite east of Yapoah Lake (late Pleistocene) - Apron of mafic (52.8-53.2\% $\mathrm{SiO}_{2}$, at $1.3 \% \mathrm{TiO}_{2}$ and $0.85 \% \mathrm{~K}_{2} \mathrm{O}$ ) lava flows on north-northeast flank of North Sister that carry conspicuous clusters of olivine and plag mph. Glaciated flows crop out widely between 6,000 and 5,400 ft elevation between Yapoah Lake and Alder Creek. Source is probably North Sister or unidentified vent on its north flank. Ice-scoured ledges, ribs, and knobs are mostly devitrified and block jointed or slabby, but zones that remain partly glassy crop out locally. Phenocrysts: true phenocrysts are sparse, but clusters of olivine mph and clots of intergrown plag and olivine $\mathrm{mph}$ are abundant and diagnostic of unit; most clots are $0.5-1.5 \mathrm{~mm}$ across and rarely as big as $5 \mathrm{~mm}$; altogether contains $3-5 \%$ olivine $(0.2-2 \mathrm{~mm})$ and $<1 \%$ plag phenocrysts $(0.5-1 \mathrm{~mm})$, but abundant plag mph are seriate to groundmass microlites. Overlies units myl and bac $(128 \pm 7 \mathrm{ka})$ and either overlies or intercalates with some clot-poor older North Sister lavas (unit mns). Overlain by units mfy, mwy, mys, and younger lavas of unit mns. Unit appears to be sequence of North Sister flows that represent subtly distinguishable variant intercalated within dominant sequences of unit $\mathrm{mns}$ lavas (which are chemically slightly different at $53-55 \% \mathrm{SiO}_{2}, 1.0 \% \mathrm{TiO}_{2}$, and $0.7 \% \mathrm{~K}_{2} \mathrm{O}$ ). Undated [NS, TCB]

Basaltic andesite of fissure vent south of Yapoah Lake (late Pleistocene) - Glaciated ridge of fissure-fed, brick-red mafic (56.2-57.6\% $\mathrm{SiO}_{2}$ ) scoria lapilli and bombs, just north of Knob 6435 and about $1 \mathrm{~km}$ south of Yapoah Lake. Scoria ridge is $400 \mathrm{~m}$ long, trends N. $10^{\circ}$ to $20^{\circ} \mathrm{E}$., has 40 to $60 \mathrm{~m}$ of relief, is strewn with varied erratics, and is surrounded by glacially eroded remnants of apron of comagmatic fountain-fed lavas. Scoria exposures generally are nonindurated, not agglutinated; lavas are massive, block jointed, and eroded into bold ledges that shed coarse talus. Phenocrysts: almost none; rare plag $(0.5-1.5 \mathrm{~mm})$; rarer olivine $(<1$ $\mathrm{mm})$. Overlies units mey, mns, and myl. Overlain by unit mwa. Undated [NS] 
mhd Basaltic andesite of Hayden Glacier-Diller Glacier cleaver (late Pleistocene) - Stack of several mafic (54.5-56.2\% $\mathrm{SiO}_{2}$ ) lava flows and intercalated coarse scoria falls that make up prowlike cleaver between Diller and Hayden Glaciers below east face of Middle Sister. About seven flows, ranging in thickness from 5 to $30 \mathrm{~m}$, form cliffy, 150-m-high section at head of cleaver. Scoria-fall intervals as thick as $10 \mathrm{~m}$ include spindle bombs. Lower flows dip west (as if they originally banked against ice or were later rotated?), whereas upper flows dip $15^{\circ}$ east and project across ice-filled saddle into stack of about 15 ochre-weathering lava flows, which make up middle of three main sequences that constitute steep east face of Middle Sister. Lithology varies widely from vitrophyric and vesicular to massive devitrified interior facies, commonly slabby or block jointed. Phenocryst contents vary widely among flows: $7-15 \%$ plag (mph to $1.5 \mathrm{~mm}$, rarely as big as $3 \mathrm{~mm}$ ); $1-3 \%$ olivine ( $\mathrm{mph}$ to $1 \mathrm{~mm}$, rarely to $2 \mathrm{~mm}$ ), some having spinel inclusions; rare to common oxide $\mathrm{mph}$; most flows also contain sparse cpx (mph to as big as $0.7 \mathrm{~mm}$ ). Cleaver is surrounded by till and ice, so base of stack is not exposed. On face of Middle Sister, stack of flows overlies stratified tephra fall of unit aef and underlies cone-forming stack of mms lavas. ${ }^{40} \mathrm{Ar} /{ }^{39} \mathrm{Ar}$ age: $37 \pm 9 \mathrm{ka}$, for thick flow at east end of cleaver [NS]

$\mathrm{mhl} \quad$ Basaltic andesite of headwaters of Linton Creek (late Pleistocene) - Small (300 by $200 \mathrm{~m}$ ) window of glacially scoured, moderately porphyritic mafic $\left(54.6,55.7 \% \mathrm{SiO}_{2}\right)$ lava flows at head of middle fork of Linton Creek (UTM grid 949/876). Ledgy exposure at 6,550 to 6,750 $\mathrm{ft}$ elevation on west slope of Middle Sister is set of four flows, each 2 to $6 \mathrm{~m}$ thick, that have normal lithologic zoning, from rubbly bases to massive devitrified block-jointed interiors sandwiched by vitrophyric (commonly vesicular) tops and bottoms. Phenocrysts: $\sim 5 \%$ plag (mph to $1.5 \mathrm{~mm}) ;<1 \% \mathrm{cpx}$ (mostly $\mathrm{mph}$, rarely as large as $0.7 \mathrm{~mm}$ ); traces of olivine and oxide mph; also contains common crystal clots, either all plag, plag-cpx, or plag-cpx-oxide. Overlies unit dlc. Draped by unit ahl $(21 \pm 3 \mathrm{ka})$ and by great apron of unit mms that largely conceals it. Chemically identical to lavas of unit $\mathrm{mhd}$, which likewise is directly overlain by unit mms lavas on opposite side of Middle Sister edifice. Undated but probably older than unit alc $(27.2 \pm 1 \mathrm{ka})[\mathrm{NS}]$

mhr Basaltic andesite of The House Rock (late Pleistocene) - Small, asymmetrical mafic (53.3-53.5\% $\mathrm{SiO}_{2}$ ) shield west of Wickiup Plain, built on south flank of much older larger shield, The Wife. Glaciated remnants of scoria cone and small plug (not mapped) crop out atop shield; lava-flow apron extends $2 \mathrm{~km}$ southward. Phenocrysts: 5-7\% plag (0.5-2 mm); $3-5 \%$ olivine (mostly $\mathrm{mph}$, rarely as big as $1.5 \mathrm{~mm}$ ); sparse oxide mph. Groundmass rich in plag-lath $\mathrm{mph}$. Northwest contact only approximate where lavas overlie unit mtw; adjacent lava-flow apron of glaciated Koosah Mountain shield (unit mkm) appears to be younger; postglacial lava flows of unit mlc bank against The House Rock. ${ }^{40} \mathrm{Ar} /{ }^{39} \mathrm{Ar}$ age: $67 \pm 4 \mathrm{ka}$ [SS]

mkm Basaltic andesite of Koosah Mountain (late Pleistocene)-Small mafic (52.6-53.3\% $\mathrm{SiO}_{2}$ ) shield volcano centered $2 \mathrm{~km}$ west of Kokostick Butte, at southwest edge of map area. From vent complex marked by scoria cone (stippled on map) atop Koosah Mountain, apron lavas extend at least $1.5 \mathrm{~km}$ northward and at least $4 \mathrm{~km}$ southward beyond edge of map area. Everywhere glaciated, lava flows crop out as ice-smoothed ribs and steps, widely massive, block jointed, and well exposed. Unit forms undulating bedrock surface of ice-scoured basin that contains 25 or more lakes of Sisters Mirror Lake cluster. Scoria cone that caps shield is about $150 \mathrm{~m}$ high and $1.2 \mathrm{~km}$ long, elongate north-south, and is marked by fissure vent along its crest; ejecta near summit are generally oxidized and widely agglutinated, ranging from tack-welded through densely blobby to fully homogenized sheets of lava. Bombs along crest are commonly as big as $50 \mathrm{~cm}$, rarely bigger than $1 \mathrm{~m}$, and mostly brick red. Phenocrysts: $3-5 \%$ olivine $(0.2-2 \mathrm{~mm})$, commonly in clusters; plag sparse $(0.5-1 \mathrm{~mm})$. Groundmass is choked with plag laths, seriate from microlites to $\mathrm{mph}$, rarely as long as 0.5 $\mathrm{mm}$. Apron lavas appear to bank against unit $\mathrm{mhr}(67 \pm 4 \mathrm{ka})$; they are intruded by domes

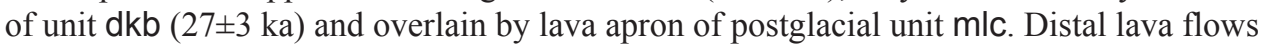
near and southeast of highway are likewise glaciated but slightly more evolved, containing $54-55 \% \mathrm{SiO}_{2}$, less olivine, and slightly more plag than most of unit; although here assigned to this unit, they could represent a sequence of older flows. Undated [SS]

mlb Basaltic andesite of Little Brother (late Pleistocene) - Glacially sculpted mafic (52.2-53.1\% $\mathrm{SiO}_{2} ; \mathrm{n}=10$ ) edifice, about $2 \mathrm{~km}$ in diameter, at northwest toe of North Sister, as well as 
apron of numerous lava flows that extends $6 \mathrm{~km}$ west to Obsidian Creek and $6 \mathrm{~km}$ northwest to Frog Camp Creek (outside mapped area). Steep edifice has more than $300 \mathrm{~m}$ of proximal relief and consists of agglutinate, scoria-fall layers, and hundreds of thin lava flows, many of them fountain fed and only 1 to $5 \mathrm{~m}$ thick. On west ridge of edifice, as many as 30 such flows are exposed in given sections. A few late flows are 5 to $15 \mathrm{~m}$ thick. Near summit, many fragmental deposits, both loose and agglutinated, are oxidized brick red. On slopes, many scoria layers are black, although colorfully palagonitized locally. Several comagmatic dikes and small plug cut edifice strata, principally on north and northeast sides. Apron lavas tend to be thicker, 5 to $15 \mathrm{~m}$, but are poorly exposed, glaciated, and till strewn; they commonly are glassy, or partly so, and vesicular, although massive devitrified interior zones are exposed in thicker flows. Window at 4,600 to 4,800 ft elevation along lower canyon of Obsidian Creek is mostly devitrified, massive, and slabby. Phenocrysts: $1-5 \%$ plag $(0.5-1.5$ $\mathrm{mm}$ ), seriate to as much as $15 \%$ plag-lath $\mathrm{mph}$ in some samples; $3-5 \%$ olivine (mph to 1 $\mathrm{mm}$, rarely as big as $2.5 \mathrm{~mm}$ ); most samples have abundant olivine-plag clots and fewer all-plag clots, both types limited largely to mph. Schmidt (2005) listed chemical data for 30 additional samples, which range in $\mathrm{SiO}_{2}$ content from 52.6 to $53.9 \%$. Appears to overlie youngest (valley-floor) flows of unit mns near snout of Collier Glacier (UTM grid 966/9175; there, 46.2 $\pm 5.6 \mathrm{ka}$ ). Overlain by units acc, alc, awc, mmm, msb, dss, roc ( $38 \pm 2$ $\mathrm{ka})$, and aoc (45-49 ka). Preserved locally atop west ridge of Little Brother edifice are remnants of two sets of stratified fallout, each about $50 \mathrm{~cm}$ thick, that are predominantly pumice lapilli and lithic fragments (both of aphyric rhyolite) probably related to unit roc (Sherrod and others, 2004). ${ }^{40} \mathrm{Ar} /{ }^{39} \mathrm{Ar}$ ages: $47.2 \pm 5.8 \mathrm{ka}$ (medial), $48.4 \pm 3.6 \mathrm{ka}$ (distal) [LL, NS]

mlc Basaltic andesite of Le Conte Crater (early Holocene or latest Pleistocene)-Postglacial scoria cone (stippled on map) at southern margin of Rock Mesa and associated aprons of mafic (54.5-55.9\% $\mathrm{SiO}_{2}$ ) lava flows that extend 3 to $4 \mathrm{~km}$ northwest to Mesa Creek and 6 to $7 \mathrm{~km}$ south in tongues that bifurcate around Kokostick Butte (unit dkb). Cone is $120 \mathrm{~m}$ high, is $600 \mathrm{~m}$ in diameter, and has shallow 200-m-wide circular summit crater. Cone has no exposure, as it is heavily mantled with late Holocene pumice-fall deposit of unit rrm; where exposed through fallout, lava-flow surfaces are rubbly, scoriaceous, and virtually uneroded, having many ridges, hillocks, and blocky levees. Flows are not incised but ubiquitously have 2 to $10 \mathrm{~m}$ of local relief. Southeast tongue impounds Devils Lake. Phenocrysts: $3-5 \%$ olivine (mph to $1 \mathrm{~mm}$, very rarely to $3 \mathrm{~mm}$ ), some in clusters; virtually no truly phenocrystic plag. Groundmass commonly is rich in plag-lath $\mathrm{mph}(<0.5 \mathrm{~mm}$ long); plag antecrysts (sieved, partly resorbed, and $0.5-1.8 \mathrm{~mm}$ ) are sparse but widespread. Clark (1983) reported resorbed quartz xenocrysts. Overlain by unit rrm and Mazama ash (7.7 ka). Younger than all other contiguous units, including slump mass from Katsuk Butte. Undated [SS]

mls Basaltic andesite of Linton Spring (late or middle Pleistocene)-Cliff-forming, phenocrystpoor mafic $\left(55.1 \% \mathrm{SiO}_{2}\right)$ lava flow adjacent to Linton Meadows, $4 \mathrm{~km}$ southwest of Middle Sister summit. Exposed as west-facing scarp for about $700 \mathrm{~m}$, glaciated flow is more than $50 \mathrm{~m}$ thick. Voluminous Linton Spring (discharge roughly 2,000 1/s) gushes from numerous orifices in flow-breccia zone that makes up lower $20 \mathrm{~m}$ of outcrop. Most of unit is dark gray, chunk jointed, and glassy, aphanitic, or finely crystalline. Thickness, jointing, and texture suggest ice-contact emplacement. Phenocrysts: $1-2 \%$ plag $(0.5-3 \mathrm{~mm}$, mostly $\sim 1 \mathrm{~mm})$; $<<1 \%$ olivine (mostly $\mathrm{mph}$, rarely $1-2 \mathrm{~mm}$ ). Base not exposed, but unit probably overlies unit $\mathrm{mth}$. Overlain by unit $\mathrm{mms}$. Undated [NS]

$\mathrm{mmc}$ Basaltic andesite of Millican Crater (late Pleistocene)-Mafic (53-54\% $\mathrm{SiO}_{2}$ ) scoria cone and associated lava-flow apron at north-central edge of map area. Fragmental cone has $250 \mathrm{~m}$ of relief, is 1,200 m wide, and banks against Black Crater edifice; its 2 by $3 \mathrm{~km}$ apron extends mostly to south and east. Glaciated apron consists of numerous block-jointed lava flows that are meagerly exposed but support several peripheral ledges 5 to $12 \mathrm{~m}$ high. Upper part of cone consists of radially dipping stratified scoria, extensively oxidized brick red, locally agglutinated, but only modestly eroded, probably having stood higher than regional glacial surface. Subhorizontal layers of scoria and agglutinate near summit are fallout that filled transient crater. Phenocrysts: sparse plag $(0.5-1 \mathrm{~mm})$; only tiny olivine $(\leq 0.5 \mathrm{~mm})$; sparse oxide $\mathrm{mph}$; sparse olivine-plag clots; some lava flows have no phenocrysts $(\geq 0.5 \mathrm{~mm})$. Overlies unit mbc. Overlain by units bwm and $\mathrm{mnt}(20 \pm 5 \mathrm{ka})$. Normal paleomagnetic polarity (Taylor, 1987). Undated [NS, TCB] 
$\mathrm{mmi}$

Basaltic andesite intrusion of Middle Sister (late Pleistocene) - Vertical mafic (52.8, 53.3\%

$\mathrm{SiO}_{2}$ ) intrusive mass exposed on northeast face of Middle Sister for about $200 \mathrm{~m}$ from Hayden Glacier nearly to ridgecrest just north of summit. Flares upward from thick dike below to as wide as $40 \mathrm{~m}$ at top. Probably one major conduit for later parts of 225 -m-thick pile of (compositionally similar) thin rubbly flows (unit mms) that built top part of Middle Sister edifice. Porphyritic, having medium-grained groundmass. Phenocrysts: $30-40 \%$ plag (mph to $4 \mathrm{~mm}$ ); $5 \%$ olivine (mph to $1.5 \mathrm{~mm}$, rarely $3 \mathrm{~mm}$ ), much of it altered; abundant oxides $(0.1-0.2 \mathrm{~mm})$ limited to groundmass. Cuts stacks of lava flows of units $\mathrm{mms}$ and mhd, and probably underlying tephra-fall deposit of unit aef as well. ${ }^{40} \mathrm{Ar} /{ }^{39} \mathrm{Ar}$ age: $18 \pm 4 \mathrm{ka}$ [NS]

$\mathrm{mml}$ Basaltic andesite of South Matthieu Lake (late Pleistocene) - North-trending set of three separate glaciated windows of moderately porphyritic mafic $\left(54.4-55.6 \% \mathrm{SiO}_{2}\right)$ lava exposed along contacts between units mpn, mps, and postglacial lava flows from Yapoah Crater (unit myc). Ice-scoured ledges and knobs are massive, slabby to block jointed, or locally partly glassy and chunk jointed. Phenocrysts: $2-3 \%$ plag $(0.5-1.5 \mathrm{~mm}$, rarely to $3 \mathrm{~mm}) ;<1 \%$ olivine $(0.2-1 \mathrm{~mm})$; rare cpx $\mathrm{mph}$; olivine commonly in clusters; olivine-plag intergrowths probably antecrystic. Overlies unit $\mathrm{mps}$. Overlain by units $\mathrm{mmn}, \mathrm{mpn}$, and myc. Undated [NS]

$\mathrm{mmm}$ Basaltic andesite of Montague Memorial (late Pleistocene)-Single thick phenocryst-rich mafic (56.3-57.3\% $\left.\mathrm{SiO}_{2}\right)$ lava flow that extends about $2.5 \mathrm{~km}$ northwest from toe of Middle Sister edifice, as narrow tongue that is banked against southern margin of Obsidian Cliffs coulee (unit roc). Makes up narrow strip of glaciated knobs that may have been emplaced along margin of glacier during last major glacial episode. In periphery of southeastern knob (most proximal remnant exposed), unit was wholly removed by glacial erosion. Vent apparently was farther southeast, higher on Middle Sister, and is now concealed by younger units. Internal zones are devitrified and block jointed or slabby. Black vitrophyre and partly glassy zones are locally exposed, and scoriaceous oxidized rubbly base (atop unit aoc) crops out in several places. Small remnant of second flow unit caps largest (central) Knob 6543. Phenocrysts: $15-20 \%$ plag (mph to $2.5 \mathrm{~mm}$, rarely as big as $4 \mathrm{~mm}$ ); 3-5\% pyroxenes (mph to $2 \mathrm{~mm}$, rarely as long as $3.5 \mathrm{~mm}$ ); sparse oxide mph. Overlies units aoc, mlb, and roc (37.8 $\pm 1.8 \mathrm{ka})$. Overlain only by till, locally. ${ }^{40} \mathrm{Ar} /{ }^{39} \mathrm{Ar}$ age: $19 \pm 7 \mathrm{ka}[\mathrm{NS}]$

$\mathrm{mmn}$ Basaltic andesite of North Matthieu Lake (late Pleistocene) - Phenocryst-poor mafic (54.6\% $\mathrm{SiO}_{2}$ ) lava flow that forms north-facing scarp $75 \mathrm{~m}$ high and ice-scoured bench $600 \mathrm{~m}$ wide that supports North Matthieu Lake. Knobby bench lava is massive, locally vesicular, and block jointed to slabby. Phenocrysts: $1-2 \%$ plag $(0.5-1.5 \mathrm{~mm}$, rarely to $3 \mathrm{~mm})$; sparser olivine (mostly $\mathrm{mph}$ ). Overlies unit $\mathrm{mml}$. Overlain by unit $\mathrm{mpn}$ and by postglacial lava flow from Yapoah Crater (unit myc). Undated [NS]

mms Basaltic andesite of Middle Sister (late Pleistocene) - Shingled stacks of thin phenocryst-rich mafic lava flows and intercalated blocky rubble that constitute most of upper half of Middle Sister cone and mantle much of its south and west apron. Most flows contain 52.2-52.9\% $\mathrm{SiO}_{2}(\mathrm{n}=25)$, but some late flows and dikes contain 53.3-54.1\% $\mathrm{SiO}_{2}$. Unit is $225 \mathrm{~m}$ thick on east face of edifice. Apron extends continuously $4 \mathrm{~km}$ south and west, and patchy remnants survive as far as $2 \mathrm{~km}$ north, $3 \mathrm{~km}$ northwest, and $5 \mathrm{~km}$ east of summit. Altogether, unit consists of hundreds of flows, many only 1 to $2 \mathrm{~m}$ thick; a few medial sections expose as many as 40. East face and lower parts of aprons are glacially excavated, but steep upper slopes of cone on south and west are not. Least modified surfaces remain scoriaceous and rubbly to blocky. Eroded flows form stairstep ledges that dip radially and tend to thicken downslope. Where 1 to $2 \mathrm{~m}$ thick, most flows remain partly glassy; where 3 to $7 \mathrm{~m}$ thick, most have devitrified internal zones (1-5 m thick) that are typically massive or slightly vesicular and block jointed. Oxidized, scoriaceous rubble zones are widely exposed between flows. A few remnants survive of distal flows that ponded as thickly as 10 to $15 \mathrm{~m}$, perhaps along glacier margins. Several dikes, 1 to $2 \mathrm{~m}$ thick, are exposed on west slope and east face of Middle Sister; compositionally similar to lavas they cut, they supplied later increments to accumulating pile of flows; similar dikes also cut unit mcl on southeast slope. Summit area consists predominantly of ejecta, poorly or crudely stratified and having variably agglutinated stringers that grade outward into thin, ledge-forming, fountain-fed lava flows. Summit ridge is mantled locally by units $\mathrm{dhr}$ and dms and by one tiny remnant of unit mss (UTM grid 
9736/8893; about $80 \mathrm{~m}$ north of high point at $10,047 \mathrm{ft}$ elevation). Summit ridge is remnant of west rim of former vent complex sited slightly eastward that was subsequently removed by glacial excavation of east face of edifice; upward-flaring intrusive unit mmi is remnant or offshoot of feeder system. Fumarolic alteration of fragmental summit material, now orange, yellow, ochre, or brick red, and locally coated by white films on joint faces, extends about $200 \mathrm{~m}$ north and south of true summit and to depth of at least $30 \mathrm{~m}$ as exposed on east face. Phenocrysts: $25-35 \%$ plag ( $\mathrm{mph}$ to $4 \mathrm{~mm}$, equant or elongate); $5-10 \%$ olivine (mph to 2.5 $\mathrm{mm}$ ), commonly in clusters and some with spinel inclusions. Few plag crystals are sieved except in near-vent samples from summit. Overlies units adl, ahl, alc, alg, anh ( $21 \pm 6 \mathrm{ka})$,

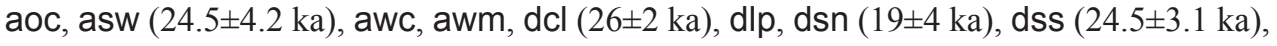

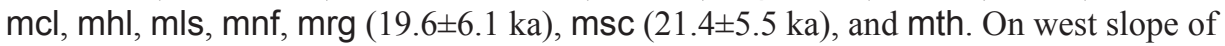
Middle Sister, several flows bank against previously eroded vent-filling extrusion of unit dlp (21.4 $\pm 1.9 \mathrm{ka})$. Overlain by units dbh (18 $2 \mathrm{ka})$, dhr (19 $\pm 2 \mathrm{ka})$, dig (14 $\pm 3 \mathrm{ka}), \mathrm{dms}$,

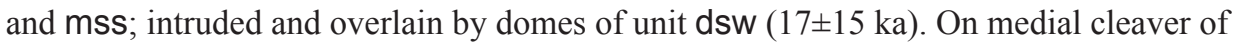
Collier Glacier, stack of five thin flows is sandwiched between lavas of unit awc ( $22 \pm 2 \mathrm{ka})$ below and dbh (18 $2 \mathrm{ka})$ above. ${ }^{40} \mathrm{Ar} /{ }^{39} \mathrm{Ar}$ age: $16.4 \pm 11.7 \mathrm{ka}$, for sample from true summit of Middle Sister $\left(0.79 \% \mathrm{~K}_{2} \mathrm{O}\right)$. Ages of so many enclosing units bracket eruptive interval to about $20 \mathrm{ka}$; statistical propagation of ages of bracketing units yields $20.3 \pm 2.5 \mathrm{ka}$ [NS, SS, TCB]

mms' Pyroxene-bearing variant of the basaltic andesite of Middle Sister (late Pleistocene) Moderately porphyritic lava flows at or near top of sequence of flows of unit $\mathrm{mms}$, distinguished by much lower total phenocryst content, presence of sparse cpx, and slightly more evolved bulk composition (54.5-54.9\% $\left.\mathrm{SiO}_{2}\right)$. Directly atop of, or intercalated near top with, stack of lavas of unit mms, this variant is presumed to be comagmatic with unit mms and to have been more extensive prior to glacial erosion. Recognized in two areas on opposite sides of Middle Sister: (1) banked against and lapped onto vent intrusion of unit dlp at 7,850 to $8,200 \mathrm{ft}$ elevation on west slope, and (2) on east apron at 6,600 to 6,800 ft elevation, close to North Fork Whychus Creek. Steep western flows are 2 to $4 \mathrm{~m}$ thick, vesicular, rubbly, and partly glassy; on more gently sloping eastern apron, flows are 5 to $8 \mathrm{~m}$ thick, glacially scoured, massive, devitrified, and block jointed to slabby. Phenocrysts: $5-10 \%$ plag (mph to $3 \mathrm{~mm}$ ); 1\% olivine (mph to $2 \mathrm{~mm}$ ); sparse cpx (mostly $\mathrm{mph}$, rarely $0.5-2 \mathrm{~mm}$ ); trace oxide $\mathrm{mph}$. Erupted at or near end of eruptive sequence of unit mms. Overlies units awm, dlp, and $\mathrm{mcl}$. Undated, but same age as unit mms (about $20 \mathrm{ka}$ ) [NS, TCB]

$\mathrm{mmt}$ Basaltic andesite tuff of Middle Sister (late Pleistocene) - Discontinuous patches of poorly sorted mafic (51.7-55.2\% $\left.\mathrm{SiO}_{2} ; \mathrm{n}=3\right)$ tuff (samples of bulk tuff were picked free of lithic fragments), exposed in hollows on glacially scoured surface of multiflow lava apron of unit $\mathrm{mms}$ along west toe of Middle Sister. Originally intercalated between thin lava flows that were variably stripped by glacial erosion, abundant remnants of tuff suggest formerly continuous flow fan that extended from Separation Creek northward for $3.5 \mathrm{~km}$ to Lane Plateau. Exposures are limited to apron of modest relief below break in slope of steep cone of Middle Sister, ranging in elevation from $6,850 \mathrm{ft}$ down to $6,000 \mathrm{ft}$ near Linton Meadows. Flows may have originally extended farther down Linton Creek, as sandy postglacial alluvium there appears to be in considerable part derived from this tuff. Exposures are on walls of drainages or form broad ice-scoured whalebacks; tuff is moderately to poorly indurated, medium gray (weathering pale gray or tan when dry), and either massive or crudely stratified. Locally developed internal shear and crude size sorting produced vague partings that result in slabby splitting and ledgy outcrops that erode into ribs 5 to $50 \mathrm{~cm}$ thick. Base is rarely exposed, but observed thicknesses of remnants range from 4 to $25 \mathrm{~m}$. Juvenile clasts are phenocrystrich black scoriae, poorly to strongly vesicular, mostly 1 to $10 \mathrm{~cm}$ (but as big as $20 \mathrm{~cm}$ ), and identical to material in lavas of enclosing unit mms. Matrix is predominantly crystal-rich coarse ash, which supports most clasts and commonly is vesicular. Accidental lithic clasts, rare or absent in higher exposures, are common distally, apparently entrained downslope; most are andesite-dacite lavas, and fewer are basalts; most clasts are smaller than $5 \mathrm{~cm}$, but some are as large as $35 \mathrm{~cm}$. Absence of welding makes mafic pyroclastic-flow emplacement process unlikely. Mud-lined vesicles in gritty matrix suggest dewatering of granular material and transport of sparse fines. Lack of wood fragments in deposit probably reflects barren edifice in late Pleistocene; upper slopes of Middle Sister remain barren today. Deposit can 
be interpreted as product of one or many primary lahars, presumably initiated by modest scoria showers or surges in summit region during eruptive interval that also produced lava flows of unit mms. Falling on snow or ice, hot pyroclasts would mix with meltwater and pour rapidly downslope, probably bulking by incorporation of loose ash and scoria during transit (but picking up accidental lithic fragments only distally, where units older than $\mathrm{mms}$ were exposed). Still today, upper slopes of Middle Sister remain snow covered for 9 to 10 months a year. Tuff has not been observed east of edifice, where apron is deeply eroded and extensively till covered. Phenocrysts: same as unit $\mathrm{mms}$. In thin section, indurated tuff matrix (exclusive of basaltic lapilli) typically consists of $\sim 25 \%$ glass shards $(0.2-2 \mathrm{~mm}$ ), $5-10 \%$ plag (mph to $2 \mathrm{~mm}$ ), and $3-5 \%$ olivine ( $\mathrm{mph}$ to $1 \mathrm{~mm}$ ) in finely comminuted matrix of same constituents. Overlies units alc and msc. Undated (but same as unit mms, about 20 ka) $[\mathrm{NS}, \mathrm{SS}]$

mnf Basaltic andesite of North Fork Whychus Creek (late Pleistocene) - Glaciated, moderately porphyritic, mafic (53.6-54.4\% $\mathrm{SiO}_{2}$ ) lava flows exposed through till in several windows along, and north of, North Fork Whychus Creek between 6,200 and 7,200 ft elevation. Crops out along stream gorge, where set of four flows, each 1 to $3 \mathrm{~m}$ thick, is well exposed (UTM grid 012/8885). Conformably beneath them, fifth flow is compositionally similar but phenocryst richer and more than $10 \mathrm{~m}$ thick, its base not exposed. For $400 \mathrm{~m}$ north of North Fork gorge, unit crops out through till in isolated patches as ledges and gully walls, mostly devitrified. Largest exposure is 50-m-thick stack of 10 flows (each 2 to $7 \mathrm{~m}$ thick) that forms steep till-enveloped buttress (UTM grid 995/883) at 7,000 to 7,200 ft elevation near head of North Fork. Most lavas there are partly glassy and vesicular, but thicker ones expose devitrified massive block-jointed interiors. Phenocrysts: $5-10 \%$ plag $(0.5-2.5 \mathrm{~mm}) ; 1-3 \%$ olivine (mph to $1.5 \mathrm{~mm}) ;$ ssparse cpx $(\leq 1 \mathrm{~mm})$. In some coarsely crystalline samples, plag mph (0.1-0.4 mm) make up 30-40\% and olivine mph as much as $10 \%$ of thin sections. Probably erupted at Middle Sister (prior to eruption of major summit-capping unit mms). Base not exposed. Overlain by units adl $(24 \pm 1 \mathrm{ka}), \mathrm{mcl}$, and $\mathrm{mms}$. Chemically identical to lavas of unit mnh ( $2 \mathrm{~km}$ northwest). ${ }^{40} \mathrm{Ar} /{ }^{39} \mathrm{Ar}$ age: $48 \pm 10 \mathrm{ka}$ [NS, TCB]

mnh Basaltic andesite north of Hayden Glacier (late Pleistocene) - Stack of thin, moderately porphyritic mafic lava flows that crops out through till as two ledges, each less than $100 \mathrm{~m}$ long, along north edge of Hayden Glacier. Upper ledge at 8,450 to 8,500 ft elevation exposes two flows, each partly glassy and 1 to $2 \mathrm{~m}$ thick (UTM grid 9793/8978). Lower ledge at 8,300 to $8,350 \mathrm{ft}$ elevation exposes five flows (UTM grid 9806/8963), among which first four are similarly thin and compositionally like those of upper ledge (all 53.4-54.4\% $\mathrm{SiO}_{2}$ ); all have massive devitrified interior zones ( $1 \mathrm{~m}$ thick or less) enclosed by glassier, more vesicular tops and bottoms. Top flow of lower ledge is different, but it is not possible to represent it separately at scale of map; although conformable with those below, it is 7 to $10 \mathrm{~m}$ thick, has $57.1 \% \mathrm{SiO}_{2}$, and (in common with fourth flow) contains fewer crystals. Phenocrysts (most flows): $7-12 \%$ plag (mph to $2 \mathrm{~mm}$ ); $1-2 \%$ olivine (mph to $1 \mathrm{~mm}$ ); \pm subordinate cpx. Top two flows of lower ledge contain only $2-3 \%$ plag (mph to $1 \mathrm{~mm}$ ); $\leq 1 \%$ olivine (mph to 1 $\mathrm{mm}) ; \sim 1 \% \mathrm{cpx}(0.5-1 \mathrm{~mm})$; in other flows, cpx is sparse or absent. All flows contain sparse oxide mph and clots of all minerals, in varied combinations. Although contacts are everywhere obscured by till, unit probably underlies nearby units $\mathrm{mms}$ and $\mathrm{dbh}$; it certainly is younger than nearby unit $\mathrm{mns}$. All flows but top one are chemically similar to flows of unit mnf, about $2 \mathrm{~km}$ southeast. ${ }^{40} \mathrm{Ar} /{ }^{39} \mathrm{Ar}$ age: $21 \pm 6 \mathrm{ka}$ (for top flow of lower ledge) [NS]

mns Basaltic andesite of North Sister (late and middle Pleistocene) - Glacially ravaged mafic stratocone (52.5-55.1\% $\mathrm{SiO}_{2} ; \mathrm{n}=140$; see also Schmidt, 2005) on Cascade Range axis just north of Middle Sister and $10 \mathrm{~km}$ south of McKenzie Pass. Steep, asymmetrically preserved edifice, which is 2 by $3 \mathrm{~km}$ across and has about $1,000 \mathrm{~m}$ of relief, consists of hundreds of thin rubbly lava flows that dip radially and steeply, are intercalated with proximal agglutinate and scoria falls, and are cut by 200 or more thin dikes (Schmidt and Grunder, 2009). As many as 70 such lava flows are exposed in individual sections on walls of several ridges and cirques. Gently dipping aprons of thicker lava flows extend from edifice as far as $7 \mathrm{~km}$ east and $9 \mathrm{~km}$ northeast of summit. South and west of cone, any such apron is concealed by younger units. Half or more of cone volume has been glacially excavated and redeposited as till, largely to east and northeast. Most flows on edifice are fountain fed, 1 to $5 \mathrm{~m}$ thick, extensively vesicular (though many have massive internal zones), and typically separated by 1 to $5 \mathrm{~m}$ 
of oxidized rubbly flow breccia, scoria-fall deposits, and lag breccias left by block-and-ash flows. Exposed on steep faces within stacks of such thin rubbly flows are a few massive lavas 10 to $20 \mathrm{~m}$ thick that may be either extrusive flows or thick sills. Northwest ridge is capped by a 200-m-thick stack of flows that have massive zones 10 to $20 \mathrm{~m}$ thick, thicker on average than elsewhere on cone. Remnants of two massive lavas (each $\sim 54 \% \mathrm{SiO}_{2}$ ) cap summit and help retard edifice destruction: (1) Southern one ("Prouty Pinnacle") forms north-elongate wall $200 \mathrm{~m}$ long and $60 \mathrm{~m}$ high that appears to be plug that flares out radially over brick-red scoriaceous rubble; saddle on its crest separates two prongs, northern of which is true summit. (2) Other massive lava ("Glisan Pinnacle") lies 100 m northeast across deeper saddle and consists of 100-m-wide remnant of single flow about $35 \mathrm{~m}$ thick that dips to northeast away from plug, forms vertically jointed cliffs, and is capped by $10-\mathrm{m}$-thick agglutinate remnant.

North Sister was subdivided into several unconformable sets of flows by Schmidt (2005), who listed chemical data for 114 samples (including 38 dikes). Transition from myriad thin rubbly flows below to generally thicker and fewer flows higher on edifice is at elevations of about 9,300 ft on north face and about 9,200 ft on east face. Modest unconformities between sets of thin flows are common everywhere on edifice, but one profound unconformity crops out at about 8,750 ft elevation on east ridge, separating east-dipping flows below from west-dipping ones above; this suggests either shift in vent location, rim of filled paleocrater, or interval of severe erosion not observed elsewhere. Northeast face exposes higher proportion of intercalated brick-red scoria falls than elsewhere on edifice. West face is almost dipslope, slightly bevelling steeply dipping stack of thin brecciated flows and layers of brick-red scoria, all cut by numerous dikes.

Two parts of edifice (stippled on map) are pervasively altered to yellow-orange palagonite: entire east buttress, and 150-m-thick section low on north face. Both sections are riddled by numerous dikes (not shown on map). Buttress section, $250 \mathrm{~m}$ thick, consists dominantly of ash-rich, poorly sorted, fragmental-flow deposits, in thin to thick layers that $\operatorname{dip} 25^{\circ}$ to $30^{\circ} \mathrm{E}$. and display numerous scoured, modestly unconformable contacts. Northface section consists of ash-rich phreatomagmatic fallout, in layers 5 to $200 \mathrm{~cm}$ thick, some sloughed but mostly primary, many well sorted but others less so. In both sections, altered ashy matrix contains unaltered black or brick-red scoriae (mostly lapilli and small bombs) and angular fragments of dense gray lava 5 to $30 \mathrm{~cm}$ across. Lack of palagonitization of coarse clasts implies grain-size control on alteration, largely restricted to glassy ash-grade material; same can be inferred from unaltered condition of brick-red, ash-poor layers of scoria lapilli that intimately underlie, overlie, and interfinger with yellow palagonitized sections. Elsewhere on North Sister edifice, isolated ashy yellow layers within thick stratified sections of gray lava and red scoria confirm that alteration was controlled principally by grain size rather than depositional environment. Regularity of stratification in palagonitized sections and absence of convolution and slumping weighs against ice-contact emplacement.

Off cone proper, northeast planèze exposes about 10 lava flows, which have massive zones 2 to $20 \mathrm{~m}$ thick, are separated by thin rubbly layers, and are cut proximally by several dikes. Outflow lavas are, on average, thicker than most on edifice, commonly as thick as 10 to $20 \mathrm{~m}$ and typically are devitrified and block jointed or platy; they are discontinuously exposed through glacial deposits on forested peripheral apron. North of Pole Creek Spring, $2 \mathrm{~km}^{2}$ driftless window was not overrun by ice and uniquely retains near-primary blocky scoriaceous surface.

Although numerous flows examined vary significantly in texture and in phenocryst content, nearly all are weakly porphyritic, carrying small but varied proportions of olivine and plag phenocrysts (and, in a few flows, rare cpx). Most common are lavas that have $0.5-3 \%$ plag $(0.5-1 \mathrm{~mm}$, rarely as large as $2.5 \mathrm{~mm}$ ) and $1-5 \%$ olivine (mph to $1 \mathrm{~mm}$, rarely as big as $3 \mathrm{~mm}$ ), some in clusters. A few flows are nearly aphyric, and a few have as many as $8 \%$ plag phenocrysts. In samples that have coarse-grained groundmass, however, plag laths, seriate from 0.1 to $1 \mathrm{~mm}$, can constitute $10-30 \%$ of rock. Many of largest plag (1.5-4 mm) are actually composite intergrowths of several crystals. Oxides typically are absent or limited to groundmass and seldom $>0.1 \mathrm{~mm}$. Plag-olivine clots are sparse, in contrast to associated north-distal set of clot-rich flows mapped as unit mey. Flows exposed in windows through till in east-distal part of apron (for $6 \mathrm{~km}$ along north rim of Whychus Creek and its north fork) 
are petrographically typical North Sister lavas, but they are slightly richer than most in Ti, $\mathrm{K}$, and $\mathrm{P}$, as well as relatively deficient in $\mathrm{Al}$ (shown as unit $\mathrm{mns}$ ' in table 1 but not mapped separately). East-distal apron overlies units msp and mws. Northeast-distal apron overlies unit bac, and its flows intercalate with distinctive flows assigned to unit mey. Base of unit is not exposed to south or west. North Sister lavas are overlain by units anh, awa, dbh, mfy, $\mathrm{mlb}, \mathrm{mms}$, mnh, mps, mst, and mwa. ${ }^{40} \mathrm{Ar} /{ }^{39} \mathrm{Ar}$ ages: $119 \pm 6 \mathrm{ka}$, for flow at east-distal edge of apron on rim above confluence of Soap and Whychus Creeks; $83 \pm 25 \mathrm{ka}$, for flow on north rim of northeast planèze at 7,300 ft elevation; $71 \pm 3 \mathrm{ka}$, for flow at $8,600 \mathrm{ft}$ elevation on crest of southeast ridge of edifice; $55 \pm 5 \mathrm{ka}$, for lava that forms true summit ("Prouty Pinnacle") of North Sister; $46 \pm 6 \mathrm{ka}$, for valley-floor flow near snout of Collier Glacier. Older ages for North Sister, which were reported by Hildreth (2007) and Schmidt and Grunder (2009), we now consider unreliable [NS, TCB]

mnt Basaltic andesite north of Trout Creek (late Pleistocene)-Major phenocryst-poor mafic $\left(54.9-56.9 \% \mathrm{SiO}_{2}\right.$ ) lava flow about $1 \mathrm{~km}$ wide, which extends $6.5 \mathrm{~km}$ east from beneath base of 150-m-high scoria cone (Cone 6302) across northern part of map area to 60-m-high eroded scarp at Trout Creek Swamp. Taylor (1987) correlated it with flow that extends to Cold Spring, additional $9 \mathrm{~km}$ northeast of map area. Within map area, flow is everywhere glaciated; not so farther northeast. Scoria cone (Cone $6302 ; 54.6 \% \mathrm{SiO}_{2}$; mapped as unit $\mathrm{mpn}$ ) is widely oxidized, agglutinated, and draped by thin fountain-fed lavas; although comparably phenocryst poor, cone products are not chemically identical to lava flow of this unit and, thus, are not likely to represent same eruptive episode; cone buries source vent for lava flow. Exposures of main ice-scoured lava tongue typically are massive, devitrified, and block jointed, although flow-foliated and glassy chunk-jointed facies crop out locally (more extensively in proximal areas). Phenocrysts: distally, almost none; rare plag $(1.5-3 \mathrm{~mm})$; even rarer 1-mm olivine and cpx, all probably antecrysts. Medially, similar to distally, except that olivine mph (all $<0.4$ $\mathrm{mm}$ ) are abundant; sparse plag (1-2.5 mm, sieved and partly resorbed). Proximally, sparse plag $(0.5-1 \mathrm{~mm})$ and $\mathrm{cpx} \mathrm{mph}$. Oxides scattered throughout, all $\leq 0.1 \mathrm{~mm}$. Overlies units $\mathrm{mmc}$ and myl. Overlain by units mpn and mps. ${ }^{40} \mathrm{Ar} /{ }^{39} \mathrm{Ar}$ age: $20 \pm 5 \mathrm{ka}$ [NS, TCB]

mpm Basaltic andesite of Park Meadow (late or middle Pleistocene) — Glaciated swath, about 200 $\mathrm{m}$ wide, of moderately porphyritic, oxidized agglutinate and fountain-fed mafic $(55.5-56.0 \%$ $\mathrm{SiO}_{2}$ ) lava flows that extends from eroded spatter cone (stippled on map) at about 6,600 ft elevation (UTM grid 030/844) for about 500 m northeast toward Park Meadow. Phenocrysts: cone has $7-10 \%$ plag (mph to $1.5 \mathrm{~mm}$, rarely to $3 \mathrm{~mm}$ ); $3 \%$ olivine (mph to $1 \mathrm{~mm}$ ); sparse cpx (mph to $1 \mathrm{~mm}$ ); abundant plag-pyroxene clots $(3-10 \mathrm{~mm}$ ); sparse oxides, rarely $>0.1$ $\mathrm{mm}$. Probably overlies unit mbt. Overlain by unit awf ( $24 \pm 1 \mathrm{ka})$. Undated [BT]

mpn Basaltic andesite north of Scott Pass (late Pleistocene) - North-trending ridge of fissure-fed, phenocryst-poor mafic $\left(54.6-55.2 \% \mathrm{SiO}_{2} ; 1.48-1.54 \% \mathrm{TiO}_{2}\right)$ scoria and agglutinate that extends $2.7 \mathrm{~km}$ northward from Scott Pass to pass on Millican Crater trail just north of map area (UTM grid 085/986). Glaciated ridge is 0.5 to $1 \mathrm{~km}$ wide and steep on both sides, having as much as $150 \mathrm{~m}$ of relief; its crest is marked by several hills that apparently were foci of enhanced ejection of pyroclasts, but only one shallow crater is preserved at Cone 6302. Exposures are dominated by loose lapilli and abundant bombs (many larger than $1 \mathrm{~m}$ ) that range from black to predominantly brick red and from highly vesicular to fairly dense. Tack-welded layers are present locally, but exposures of denser cliff-forming agglutinate are few; this contrasts with adjacent fissure-fed alignment segment that continues south of Scott Pass (unit mps), which (although 2-3\% more silicic) is dominated by thick sections of densely welded agglutinate. Vent alignment also continues for $2 \mathrm{~km}$ north of map area; however, northernmost 1-km-long reach (on west shoulder of Black Crater) produced mafic $\left(54.4-54.5 \% \mathrm{SiO}_{2}\right)$ scoria and agglutinate that is far richer in plag and olivine and poorer in Ti and Fe than this unit and unit mps. Phenocrysts: $<1 \%$ plag (mph to $1.5 \mathrm{~mm}$ ); sparse cpx $\mathrm{mph}(0.1-0.4 \mathrm{~mm})$. Overlies units $\mathrm{mml}, \mathrm{mmn}, \mathrm{mnt}(20.3 \pm 4.6 \mathrm{ka})$, mps, and bwm. Steep narrow topography may, in part, reflect lateral confinement by glaciers owing to eruption during Last Glacial Maximum. Overlain by postglacial unit myc. Undated [NS]

mps Basaltic andesite south of Scott Pass (late Pleistocene) - South-trending ridge of fissure-fed, phenocryst-poor mafic $\left(56.0-58.7 \% \mathrm{SiO}_{2} ; 1.25-1.64 \% \mathrm{TiO}_{2} ; \mathrm{n}=18\right)$ scoria and agglutinate that extends about $6 \mathrm{~km}$ southward from Scott Pass; also includes intercalated fountain-fed lava flows. Glaciated ridge is as narrow as $100 \mathrm{~m}$ east of Yapoah Crater, but it is about $1 \mathrm{~km}$ 
wide near Collier Cone, and $600 \mathrm{~m}$ wide at Cone 6315, which has shallow degraded crater on top and $150 \mathrm{~m}$ of relief on its steep east side. Ejecta exhibit gradations from loose scoria that has spindle bombs as big as $1 \mathrm{~m}$ through tack-welded and blobby, rheomorphic (locally convolute) sheets to massive, homogenized lava flows that have hackly, slabby, or blocky jointing. Areas of weakly indurated, yellowish-orange-brown, ash-dominant lapilli tuff (stippled on map) were probably mildly palagonitized by fallout over snow or ice. Oxidation of ejecta likewise varies widely from black to gray to ochre to brick red. Exposed stacks of glaciated agglutinate as thick as $70 \mathrm{~m}$ form cliffs and steep ledgy slopes, although ridgecrest generally is strewn with loose or weakly welded ejecta. Phenocrysts: $<1 \%$ plag $(0.5-2 \mathrm{~mm})$; rare olivine (mph only); very rare cpx mph, generally only in cpx-plag clots; polycrystalline plag intergrowths probably antecrystic. Overlies units awa ( $25 \pm 2 \mathrm{ka})$, mns, mnt (20 55 ka), mwa (59 \pm ka), mwy, and mys. Steep narrow topography may, in part, reflect lateral confinement by glaciers owing to eruption during Last Glacial Maximum. Overlain by postglacial units acc and myc and by glaciated units $\mathrm{mml}$ and $\mathrm{mpn}$. Along much of its western margin, it also overlies agglutinate and scoria of Ahalapam Cinder Field (not mapped), likewise glaciated and phenocryst poor, that erupted from different vent chain and differs chemically $\left(55.5-56.5 \% \mathrm{SiO}_{2} ; 1.10-1.30 \% \mathrm{TiO}_{2} ; \mathrm{n}=6\right)$. Undated [NS]

$\mathrm{mrg} \quad$ Basaltic andesite of Renfrew Glacier (late Pleistocene) - Fan of moderately porphyritic mafic (54.6-54.8\% $\mathrm{SiO}_{2}$ ) lava flows about $1 \mathrm{~km}$ wide, in three lobes, on northwest flank of Middle Sister. Erupted high on edifice, but vent is covered by younger units. Highest exposures are windows, at 8,300 ft elevation, through Little Ice Age moraines of Renfrew Glacier; most distal exposure lies at 6,600 ft elevation near Pacific Crest Trail. Lavas are everywhere ice scoured but nowhere deeply incised; greatest thickness exposed is about $35 \mathrm{~m}$. Flows are 3 to $20 \mathrm{~m}$ thick, separated by a few meters of oxidized flow breccia and rubble. Unit is eroded into knobs, ledges, and smooth ridges and generally is massive, devitrified, and block jointed or slabby. Flows drape previously eroded steep slopes cut on unit awr. Phenocrysts: $7-10 \%$ plag $(0.5-2 \mathrm{~mm}$ ), seriate to $\sim 25 \%$ plag $\mathrm{mph}$; trace to as much as $1 \% \mathrm{cpx}$ (mph to 1 $\mathrm{mm}) ;<1 \%$ olivine (all $\mathrm{mph})$; sparse tiny oxide $\mathrm{mph}$. Overlies units dss ( $25 \pm 3 \mathrm{ka})$, awc, and awr (although extensively stripped off unit awr); banks against unit roc. Overlain by unit mms. ${ }^{40} \mathrm{Ar} /{ }^{39} \mathrm{Ar}$ age: $20 \pm 6 \mathrm{ka}[\mathrm{NS}]$

msb Basaltic andesite of Sims Butte (latest Pleistocene) - Postglacial scoria cone near west edge of map area and associated intracanyon tongue of mafic $\left(52.3-56.6 \% \mathrm{SiO}_{2}\right)$ lava flows that extends about $15 \mathrm{~km}$ downcanyon to west (Sherrod and others, 2004). Cone (stippled on map) has $200 \mathrm{~m}$ of relief on east, $300 \mathrm{~m}$ on west. Lapilli-fall layer extends about $1 \mathrm{~km}$ beyond base of cone; ash fall, unmapped distance farther. Proximal scoriae commonly weather yellow to ochre. Thin proximal lavas are fountain fed, rubbly, and scoriaceous. Medial to distal stacks consist of numerous rubbly flows, each 0.3 to $5 \mathrm{~m}$ thick and finely to coarsely vesicular. Thick piles of oxidized rubble accumulated locally where flows broke up over steep pitches. Phenocrysts: $\leq 1 \%$ olivine (seriate $0.1-1 \mathrm{~mm}$, but a few exceed $0.4 \mathrm{~mm}$ ); plag phenocrysts $(0.5-1.5 \mathrm{~mm})$ rare; groundmass plag is seriate from microlites to abundant mph laths, small fraction of which are as long as $0.5 \mathrm{~mm}$; sparse plag antecrysts $(0.5-2 \mathrm{~mm}$, sieved and resorbed). Analyses of 17 samples (table 1; see also Conrey and others, 2002) show no systematic compositional progression downcanyon; scoria cone, however, is least evolved, and levee at northwestern margin of lava-flow apron provides most evolved material sampled. Overlies unit mlb (47-49 ka). Overlain by unit acc and Mazama ash (7.7 ka). May be relatively early postglacial, in light of only modest weathering of late Pleistocene till beneath Sims Butte fall deposits (Sherrod and others, 2004). Undated [LL, NS]

msc Basaltic andesite of Separation Creek (late Pleistocene) - Glacially scoured $4 \mathrm{~km}^{2}$ apron of phenocryst-rich mafic (56.7-57.3\% $\left.\mathrm{SiO}_{2}\right)$ lava flows at west-northwest foot of South Sister, between Hinton Creek and Linton Meadows, extending into west-trending lobe south of Separation Creek. Vent is marked by small scoria-spatter cone (stippled on map; 56.9-57.3\% $\mathrm{SiO}_{2}$ ) only $300 \mathrm{~m}$ wide and $60 \mathrm{~m}$ high, just north of Separation Creek. Greatest thicknesses exposed on lava apron are about $60 \mathrm{~m}$, near southern limit of unit and at terminus of western tongue. Scoria and agglutinate of eroded cone are locally black, mostly oxidized brick red. Lavas are locally vitrophyric and chunk jointed (as near "Racetrack Meadow") but mostly ice scoured and plucked into ledges, knobs, and pavements that are massive, devitrified, and block jointed or slabby. Phenocrysts: $15-25 \%$ plag (mph to $3.5 \mathrm{~mm}$ ); $3-5 \%$ pyroxenes (mph 
to $1.5 \mathrm{~mm}$ ); sparse oxide and olivine $\mathrm{mph}$; abundant plag-pyroxene-oxide clots. Overlies units bhs, $\mathrm{mth}$, and ddl ( $32 \pm 2 \mathrm{ka})$; banks against toe of unit alg ( $27 \pm 1 \mathrm{ka})$. Overlain by units $\mathrm{mms}$ and $\mathrm{mmt} .{ }^{40} \mathrm{Ar} /{ }^{39} \mathrm{Ar}$ age: $21.4 \pm 5.5 \mathrm{ka}$ [NS, SS]

msf Basaltic andesite of South Fork Whychus Creek (middle Pleistocene)—Phenocryst-poor mafic (53.7-54.0\% $\mathrm{SiO}_{2}$ ) lava flows and tuff exposed only near floor of South Fork Whychus Creek, at 5,800 to 6,000 ft elevation, 300 to $500 \mathrm{~m}$ east and southeast of Demaris Lake. Unit is at least $25 \mathrm{~m}$ thick, but base is nowhere exposed. Tuff is nonindurated scoriaflow deposit exposed only on right-bank wall of stream gorge at about 5,920 ft elevation; at least $12 \mathrm{~m}$ thick and overlain by lava flow of identical composition. Black, crystal-poor scoriae are as large as $8 \mathrm{~cm}$, enclosed in poorly sorted coarse-ash matrix, which weathers orange and includes varied accidental lithic fragments $(1-5 \mathrm{~cm})$. Lavas are exposed as glaciated and water-worn ledges and gully walls; massive, devitrified, and block jointed. Phenocrysts: $1-2 \%$ plag (mph to $2 \mathrm{~mm}$, rarely to $4 \mathrm{~mm}$ ); sparse olivine $\mathrm{mph}$ (rarely bigger than $0.2 \mathrm{~mm}$ ). Groundmass rich in plag-lath mph, rarely as long as $0.5 \mathrm{~mm}$. Overlain by units adl, $\mathrm{mcl}$, and mdl. ${ }^{40} \mathrm{Ar} /{ }^{39} \mathrm{Ar}$ age: $166 \pm 16 \mathrm{ka}$ [TCB] Pleistocene) - Small, glacially eroded mafic $\left(54.2 \% \mathrm{SiO}_{2}\right)$ scoria cone at 6,200 ft elevation between Soap Creek and North Fork Whychus Creek, as well as derivative phenocryst-poor mafic $\left(54.6,54.8 \% \mathrm{SiO}_{2}\right)$ lava flows 2 to $4 \mathrm{~km}$ downstream, near their confluence. Cone (stippled on map) is $350 \mathrm{~m}$ wide and displays ice-scoured, ledgy slopes that reflect layering and varied degrees of agglutination (tack welded to moderately dense) in brick-red scoria-fall deposit; densest agglutination is on steep east face, which has $70 \mathrm{~m}$ of relief. Although dominantly lapilli, ejecta are as big as $50 \mathrm{~cm}$. Deposit is locally palagonitized yellow-orange. Lava flows are exposed along stream gorge for about $600 \mathrm{~m}$ near confluence and extend additional $1.2 \mathrm{~km}$ northeast along left-bank rim of North Fork Whychus Creek canyon. Lavas crop out as massive, devitrified, block-jointed or slabby ledges as thick as $20 \mathrm{~m}$. Oxidized rubbly zone separates two 10-m-thick flows, each supporting a waterfall at elevations 5,370 and 5,340 ft along North Fork gorge. Phenocrysts: in cone, $<1 \%$ plag (mph to rarely as big as $1 \mathrm{~mm}$ ), mostly sieved or partly resorbed; $2-3 \%$ olivine (mph to $0.7 \mathrm{~mm}$ ), some rimmed by iddingsite. In lavas, almost none; groundmass is rich in plag-lath mph, seriate to a few as long as $0.7 \mathrm{~mm} ; 2-3 \%$ olivine $\mathrm{mph}(0.1-0.4 \mathrm{~mm})$, some in clusters; very rare olivine grains as large as $0.5-1 \mathrm{~mm}$. Base of cone not exposed. Lavas overlie unit bnf (at 5,320 ft elevation on gorge floor and at 5,180 ft on canyon wall); also overlie unit mws $(175 \pm 3 \mathrm{ka})$, which in turn rests on ignimbrite of unit spt. Both cone and lavas are widely overlain by till and by distal lava of North Sister (unit mns, dated nearby at $119 \pm 6 \mathrm{ka}$, where it rests directly upon this unit). ${ }^{40} \mathrm{Ar} /{ }^{39} \mathrm{Ar}$ age: $129 \pm 6 \mathrm{ka}$ (scoria cone) [TCB]

mss Basaltic andesite of Middle Sister summit (late Pleistocene) - Sequence of thin, phenocrystrich mafic $\left(56.1 \% \mathrm{SiO}_{2}\right)$ lava flows that caps ridgecrest 100 to $300 \mathrm{~m}$ north of true summit of Middle Sister, between 9,800 and 10,000 ft elevation; also exposed on sheer east face of ridge. All exposures along summit ridge consist of partly glassy, coarsely vesicular, loose blocks as big as $2 \mathrm{~m}$ that have yellow, white, and ochre alteration minerals and sublimates on most joint faces. Phenocrysts: $15-20 \%$ plag (mph to $4.5 \mathrm{~mm}$ ); $<1 \%$ olivine (mph to $1 \mathrm{~mm}$ ). Overlies unit mms; banks against northern remnant of unit dms. Undated [NS]

mst Basaltic andesite south of Trout Creek (late or middle Pleistocene)-Isolated $1 \mathrm{~km}^{2}$ window of moderately porphyritic mafic $\left(53.3 \% \mathrm{SiO}_{2}\right)$ lava along and south of headwaters of Trout Creek, at north edge of apron of North Sister lavas. May be single flow, cropping out best as glacially eroded, southeast-facing scarp 6 to $10 \mathrm{~m}$ high, crossed by Scott Pass trail. Exposures are massive, block jointed or slabby, and mostly devitrified. Phenocrysts: $\sim 10 \%$ plag (mph to $3 \mathrm{~mm}) ; 2 \%$ olivine $(0.5-2 \mathrm{~mm})$; sparse cpx $(\sim 1 \mathrm{~mm})$ and oxide $\mathrm{mph}$. Overlies older set of distal lavas of unit mns. Overlain by unit myl and, although contact is covered by till, probably also by nearby unit mey. Undated [TCB]

mtb Basaltic andesite and basalt of Trout Creek Butte (middle Pleistocene) - Steep mafic $\left(51.8-52.7 \% \mathrm{SiO}_{2}\right)$ shield in northeast corner of map area, $4 \mathrm{~km}$ wide and having about 400 $\mathrm{m}$ of relief, as well as apron of lava flows that extends as far as $5 \mathrm{~km}$ northeast of shield's summit (Sherrod and others, 2004). Scores of flows are present; many thin proximal ones are fountain fed; flows are thicker on apron. Slopes of shield are mostly nonglaciated blocky colluvium that has few true outcrops; sparse exposures are block jointed and finely 
to coarsely vesicular. Two summit knolls consist of cliffy stratified agglutinate, widely oxidized, having layers that vary from tack welded through blobby to densely welded and nearly homogenized. Late Pleistocene moraines bank against west and southwest base of shield, but most of edifice is unglaciated. Associated ash-fall deposit is said to be preserved in nonglaciated area northeast of shield (Taylor, 1987). Phenocrysts: $1-3 \%$ plag $(0.5-1 \mathrm{~mm})$, most plag anhedral; $1-3 \%$ olivine (mostly $\mathrm{mph}$, rarely $0.5-1 \mathrm{~mm}$ ); sparse cpx in some flows; $\mathrm{mph}$ clots of plag or olivine+plag are ubiquitous and conspicuous. Groundmass typically choked with plag-lath mph, seriate to microlites. Older than units bss and bbd that bank against base of shield. ${ }^{40} \mathrm{Ar} /{ }^{39} \mathrm{Ar}$ age: $532 \pm 7 \mathrm{ka}$. Oldest unit identified in map area [TCB] multivent mafic $\left(52-57 \% \mathrm{SiO}_{2} ; \mathrm{n}=22\right)$ stratovolcano centered $8 \mathrm{~km}$ northwest of South Sister summit. Edifice is 5 by $8 \mathrm{~km}$ (elongate northwest) and retains about 1,225 m of relief despite severe erosion. Not mapped in detail by us. Extent of lava apron and distribution of vent-related intrusions was shown by Sherrod and others (2004); numerous dikes were shown schematically by Taylor and others (1987). Lithology varies widely, from glassy and vesicular to massive, devitrified, and block jointed to slabby. Plugs tend to be microgranular, having abundant olivine and plag mph. Lavas are phenocryst poor, many containing only $\sim 1 \%$ olivine and $1-2 \%$ plag (both ranging from mph to as big as $1.5 \mathrm{~mm}$ ). Overlies unit bhs, which may, in part, be an early product of The Husband center. Overlain by units acc, alc, mls, mms, and msc. Knob 6760, $3 \mathrm{~km}$ north of Indian Holes on southeast apron of The Husband, is glaciated flank vent (unit mth'; $52.8 \% \mathrm{SiO}_{2}$ ) that intruded and overlies less mafic apron of this unit. ${ }^{40} \mathrm{Ar} r{ }^{39} \mathrm{Ar}$ age for lava of Knob $6760(149 \pm 5 \mathrm{ka})$, thus, provides minimum age for The Husband edifice and for subjacent lavas of unit bhs [LL, NS, SS]

mtp Basaltic andesite of Teardrop Pool (late Pleistocene)-Mafic (53.8-56.1\% $\mathrm{SiO}_{2}$ ) agglutinate and scoria-fall deposit that caps summit of South Sister. Crudely stratified deposit mantles 350-m-wide summit crater (from which it erupted), which includes ice-ringed pond called Teardrop Pool. Ice-radar measurements show crater to be flat-floored, funnel-shaped depression filled to rim with ice as thick as $60 \mathrm{~m}$ at crater center (Driedger and Kennard, 1986). Deposit also mantles outer slopes of cone on south and west, thinning but extending 200 to $400 \mathrm{~m}$ outboard from crater rim. On north and east, however, outboard part of sheet has been eroded away, leaving edge of deposit as steep rim scarp 2 to $20 \mathrm{~m}$ high. Sheet grades up, down, and outboard from densely agglutinated (even rheomorphic) to tack welded, then to loose scoria; locally black but widely oxidized brick red; gray in 10-m-thick densely massive core of sheet exposed above headwall of Lewis Glacier. Easily confused with red and gray agglutinates and fountain-fed lavas of cone-forming unit aeg, which it drapes in places. Blocky surface of unit in summit bowl is glassy and scoriaceous, having many scoria bombs variably deformed in nondense parts of agglutinate. Just west of Teardrop Pool, stratified agglutinate $\left(10 \mathrm{~m}\right.$ thick) dips steeply $\left(45^{\circ}-65^{\circ}\right)$ both inboard and outboard, draping rim of inner crater blasted through outward-dipping strata of fragmental unit des. Around Teardrop Pool, surface of sheet dips radially inward, probably reflecting differential compaction (welding) of thicker central accumulation where infilling its own crater. This inner crater is not to be confused with outer crater (700 $\mathrm{m}$ wide at its rim) that was earlier filled by units dlg and des. Phenocrysts: $7-15 \%$ plag (mph to $5 \mathrm{~mm}$ ); $1-3 \% \mathrm{cpx}$ (mph to $1.5 \mathrm{~mm}$ ); $\leq 1 \%$ olivine mph. Overlies units aeg, dlg, des, dnt, and dnt'. Youngest unit erupted from South Sister summit vents. ${ }^{40} \mathrm{Ar} /{ }^{39} \mathrm{Ar}$ age: $22 \pm 13 \mathrm{ka}$ [SS]

$\mathrm{mts} \quad$ Basaltic andesite southeast of "Todd Creek" (middle Pleistocene) —Small glaciated mafic (56.1-56.8\% $\mathrm{SiO}_{2}$ ) spatter and scoria cone about $1 \mathrm{~km}$ due south of Todd Lake and $100 \mathrm{~m}$ northeast of Cascade Lakes Highway (UTM grid 0540/7435). Only about $25 \mathrm{~m}$ high and 120 $\mathrm{m}$ in diameter, this degraded knoll largely consists of oxidized agglutinate that crops out as blobby to densely homogenized ledges on most slopes; north slope is strewn with loose red scoria. Phenocrysts rare: trace amounts of plag $(0.5-3 \mathrm{~mm})$ and mph of olivine and pyroxene. Knoll is wrapped by postglacial lava flows of unit mec. North end of cone is in contact with glaciated rhyodacite lava (not mapped by us), which may be younger, as its surface is devoid of scoria lapilli from this contiguous cone. Undated [BT]

mtw Basaltic andesite of The Wife (middle Pleistocene) - Deeply eroded mafic (52.1-53.6\% $\mathrm{SiO}_{2}$ ) shield west of Wickiup Plain and Rock Mesa. Massive summit plug, steeply jointed, intrudes stratified, radially dipping, scoria-fall deposits and agglutinate. Several vertical dikes, 2 to 
$5 \mathrm{~m}$ thick, cut proximal strata. Apron of glacially eroded lava flows extends $2 \mathrm{~km}$ north and south and several kilometers west beyond map area. Scoria falls exposed about $500 \mathrm{~m}$ southeast and $170 \mathrm{~m}$ lower than shield summit are intercalated with lava flows and are palagonitized yellow orange, unlike red and black scoriae near summit. Lavas exposed largely are massive and devitrified. Phenocrysts: $2-5 \%$ plag $(0.5-1.5 \mathrm{~mm}$ long), seriate to felty groundmass rich in plag $\mathrm{mph} ; 2-5 \%$ olivine ( $\mathrm{mph}$ to $0.7 \mathrm{~mm}$ ); oxide $\mathrm{mph}$ abundant in plug, sparse to absent in lavas. Some proximal scoria bombs appear to contain more plag phenocrysts than apron lava flows. Base not recognized in map area. Overlain by units bsb (279 $\pm 6 \mathrm{ka})$, $\mathrm{mhr}$, bjc (148 $\pm 4 \mathrm{ka})$, ddl, mlc, and $\mathrm{rrm} .{ }^{40} \mathrm{Ar} /{ }^{39} \mathrm{Ar}$ age: $374 \pm 6 \mathrm{ka}$, for massive lava on east face of summit. Second oldest unit identified in map area [SS]

mwa Basaltic andesite west of upper Alder Creek (late Pleistocene)-Moderately porphyritic mafic (53.2-56.1\% $\mathrm{SiO}_{2}$ ) lava flows exposed as glacially sculpted ridges and cliffs, 3 to $5 \mathrm{~km}$ north of North Sister summit. Sets of two or three flows form east-facing cliffs that extend $2 \mathrm{~km}$ north-south, directly beneath ridge of phenocryst-poor pyroclastic unit mps; branching from that cliff (at UTM 985/945), second sharp ridge, about $250 \mathrm{~m}$ wide and as high as $100 \mathrm{~m}$, extends $1.2 \mathrm{~km}$ northeast to bank against Knob 6435 (unit myl). Individual flows are 25 to $60 \mathrm{~m}$ thick, and stacks of two or three are as thick as $100 \mathrm{~m}$; lavas are massive, block jointed or slabby, pale to medium gray, and everywhere ice scoured. Phenocryst contents vary widely among flows: $5-15 \%$ plag $(0.5-2 \mathrm{~mm}$, rarely to $4 \mathrm{~mm}) ; 1-3 \%$ olivine (mph to $2 \mathrm{~mm}$ ); sparse to common cpx $(0.5-1.5 \mathrm{~mm})$; stellate clusters of 10 to 25 crisscrossed plag laths (each $0.2-1 \mathrm{~mm}$ long) are common. Overlies units mns; banks against units mfy, myl, and (probably) mys. Overlain by unit mps and intruded by thick aphyric mps dike; also intruded by apparent plug of unit asy. May have vented from same fissure-vent system that later produced pyroclastic unit mps. Distinguished from unit awa, which crops out along same wall just south, by much lower phenocryst content, lower $\mathrm{Al}_{2} \mathrm{O}_{3}$ content $(<17 \%)$, and higher $\mathrm{FeO}$ content ( $>8 \%$ ) of unit awa. ${ }^{40} \mathrm{Ar} /{ }^{39} \mathrm{Ar}$ age: $59 \pm 4 \mathrm{ka}$, for basal flow of northeast ridge [NS]

mwh Basaltic andesite of Whychus Creek (middle Pleistocene) - Seven mutually isolated exposures of moderately porphyritic mafic $\left(53.2-55.2 \% \mathrm{SiO}_{2}\right)$ lava flows on upstream floor and downstream rims of Whychus Creek. Five are scattered for $4 \mathrm{~km}$, from 4,900 ft elevation in bed of North Fork Whychus Creek to 4,500 ft elevation in right-bank roadcut near confluence with Snow Creek; exposures are correlated with fair confidence on basis of petrographic similarity and narrow compositional arrays on chemical variation diagrams. These five crop out as ice-scoured, till-strewn knobs or ledges, massive, devitrified, and block jointed or slabby; exposures are less than $10 \mathrm{~m}$ thick except 70-m-thick knobby outcrop on left-bank rim (UTM grid 063/920); nowhere has base been observed. Two additional exposures lie along Whychus and Pole Creeks near and just beyond limits of late Pleistocene moraines, near east edge of map area. Blocky, scoriaceous levee is exposed along north bank of Pole Creek at about 4,200 ft elevation, and sets of slabby, water-worn ledges on both walls of Whychus Creek at 4,100 to 4,200 ft elevation provide 15 to $20 \mathrm{~m}$ of vertical exposure. Phenocrysts: $5-10 \%$ plag ( $1-3 \mathrm{~mm}$ and abundant $\mathrm{mph}$ ); $\leq 1 \%$ olivine (seriate from mph to $1 \mathrm{~mm}$ ); rare cpx ( $\leq 1 \mathrm{~mm}$, mostly in sparse clots with olivine and plag); sparse oxide mph. Overlies units awy

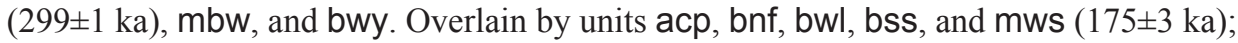
appears to lie closely beneath ignimbrite of unit spt in North Fork Whychus Creek gorge. ${ }^{40} \mathrm{Ar} /{ }^{39} \mathrm{Ar}$ age: $195 \pm 5 \mathrm{ka}[\mathrm{TCB}]$

mws Basaltic andesite west of Snow Creek (middle Pleistocene) - Phenocryst-poor mafic (53.6-55.0\% $\mathrm{SiO}_{2}$ ) lava flows recognized in three mutually separated locations along forks of Whychus Creek; correlated on basis of unusually high Ti and Fe contents. Upstreammost exposure is $600 \mathrm{~m}$ east of Upper Chush Falls, suggesting derivation from Broken Top volcano. Medial exposure along lower North Fork Whychus Creek rests directly atop ignimbrite of unit spt. Distal exposure, more than $80 \mathrm{~m}$ thick, forms west-bank wall for $800 \mathrm{~m}$ downstream from confluence of North and South Forks, Whychus Creek. All three are glacially eroded, predominantly devitrified, massive, and block jointed or slabby. Phenocrysts: $\sim 1 \%$ plag (mph to $1.5 \mathrm{~mm}$ laths); sparse olivine and cpx (both $0.5-1 \mathrm{~mm}$ ); rare oxide $\mathrm{mph}$. Overlies units spt and mwh (195 $\pm 5 \mathrm{ka})$. Overlain by units adl ( $24 \pm 1 \mathrm{ka}), \mathrm{msp}$, bnf, and ruc (169 $\pm 2 \mathrm{ka}) .{ }^{40} \mathrm{Ar} /{ }^{39} \mathrm{Ar}$ age: $175 \pm 3 \mathrm{ka}[\mathrm{TCB}]$

mwy Basaltic andesite scoria cone west of Yapoah Lake (late Pleistocene) - Small mafic (56.4-56.6\% $\mathrm{SiO}_{2}$ ) cone, 600 to $800 \mathrm{~m}$ across, just northwest of Yapoah Lake. Built on 
east-facing paleoslope, cone has maximum relief of about $90 \mathrm{~m}$ on its east side but only $10 \mathrm{~m}$ on its west side. Crater on top is $300 \mathrm{~m}$ wide and has $75 \mathrm{~m}$ of relief on its inner west wall. Rimrock is largely agglutinate, showing gradation from loose oxidized scoria through tack-welded scoria and knobbly dense agglutinate to streaky or homogenized lava, which is locally block jointed and slabby. On 5,800-ft-high nose just south of crater, its densitygraded agglutinate mantles glaciated ridge of unit mys and small cliffy window of unit myw. Cone is degraded but only modestly eroded; may have stood above or aside main late Pleistocene ice streams. Phenocrysts: almost aphyric; groundmass plag includes rare laths as long as $0.8 \mathrm{~mm} ;<<1 \%$ olivine $(0.2-0.4 \mathrm{~mm})$; very rare oxide mph. Overlies units myl, mys, and myw. Probably overlain marginally by unit $\mathrm{mps}$, but surficial deposits render that conclusion uncertain. May be related to nearby chain of scoria cones and ridges that runs north-south past Matthieu Lakes, but cone (this unit) lies east of that alignment. Undated [NS]

myc Basaltic andesite of Yapoah Crater (Holocene) - Moderately porphyritic mafic (54.5-57.0\% $\mathrm{SiO}_{2}$ ) lava flows that extend as far as $12 \mathrm{~km}$ northward from an uneroded scoria cone (stippled on map), $160 \mathrm{~m}$ high and about $500 \mathrm{~m}$ in diameter, located about $5 \mathrm{~km}$ north of North Sister. Easternmost eruptive unit of postglacial McKenzie Pass volcanic field (fig. 2); only eastern of several flows from Yapoah Crater is mapped here, essentially as border for our map area. Full extent of Yapoah lava apron has been depicted by Taylor (1968) and Sherrod and others (2004). Flows are blocky to rubbly, vesicular, little eroded, and extensively leveed. Phenocrysts: varied amounts of plag and olivine; sparse cpx. Undated, but age is bracketed by enclosing units to roughly $2.5 \mathrm{ka}$ (Licciardi and others, 1999; Sherrod and others, 2004) [NS]

myl Basaltic andesite of Yapoah Lake (late Pleistocene) - Glacially eroded, phenocryst-poor mafic (53.4-54.2\% $\mathrm{SiO}_{2}$ ) lava flows that form walls enclosing Yapoah Lake and extend about $3 \mathrm{~km}$ east-northeast and about $1 \mathrm{~km}$ south from lake. Stack is more than $70 \mathrm{~m}$ thick on scarp south of lake, but base is not exposed there. Bold ice-sculpted outcrops form knolls, ledges, ridges, and cliffs that are generally massive, devitrified, and block jointed or slabby. Vent plug is preserved as stout Knob 6435, about $1.5 \mathrm{~km}$ south of Yapoah Lake; steep-walled, glaciated knob is $75 \mathrm{~m}$ high, 200 by $250 \mathrm{~m}$ wide, and consists of massive fine-grained lava that has widely spaced, irregular joints and veneers of brick-red blobby agglutinate fused to its north and east faces. Phenocrysts: few crystals $>0.5 \mathrm{~mm}$; rare equant plag $(1-2 \mathrm{~mm})$ may be antecrystic; groundmass plag laths are seriate to as many as $20 \% \mathrm{mph}$, including rare laths as long as $1.5 \mathrm{~mm} ; 1-3 \%$ olivine $\mathrm{mph}(0.2-0.4 \mathrm{~mm}$, rarely to $0.8 \mathrm{~mm})$; distal flows have abundant oxides (rarely $>0.1 \mathrm{~mm}$ ). Overlies units mst and bwm. Overlain by units mey,

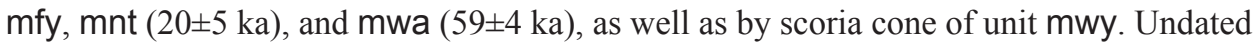
[NS, TCB]

mys Basaltic andesite southwest of Yapoah Lake (late Pleistocene) - Moderately porphyritic mafic $\left(52.5-53.2 \% \mathrm{SiO}_{2}\right)$ lava flow that forms east-facing cliff as high as $50 \mathrm{~m}$ and ice-scoured bench at 6,050 to $6,100 \mathrm{ft}$ elevation. Bench extends $1.5 \mathrm{~km}$ northward from prominent crag at 6,400 ft elevation (UTM grid 982/959) as far as scoria cone of unit mwy west of Yapoah Lake. Fine exposures are massive and slabby or block jointed. Phenocrysts: $3-5 \%$ plag $(0.5-1.5 \mathrm{~mm}$, rarely $4 \mathrm{~mm}) ; 5-8 \%$ olivine $(0.5-1 \mathrm{~mm}$, commonly in clusters; rarely as big as $3 \mathrm{~mm}$ ). Steeply jointed crag is vent plug, intruding and fusing its own oxidized scoria deposit and displaying 60-m-high scarp on its east face. North of scoria cone of unit mwy, $600 \mathrm{~m}$ along strike from principal cliffy exposures, massive angular blocks of this lava crop out poorly through till and colluvium along Scott Pass trail at 5,640 ft elevation (UTM grid 9905/9765). Overlies units mey and, inferentially, myw. Overlain by scoria cone of unit mwy and by variably agglutinated facies of phenocryst-poor pyroclastic unit mps, which banks against west wall of vent crag. Unit mwa apparently banks against south wall of vent crag, but surficial deposits obscure contact relations. Undated [NS]

myw Basaltic andesite window west of Yapoah Lake (late or middle Pleistocene)—Moderately porphyritic mafic $\left(53.0 \% \mathrm{SiO}_{2}\right)$ lava flow that crops out only as ledgy window (UTM grid 989/971), less than $100 \mathrm{~m}$ long, at 5,720 to 5,760 ft elevation on northeast-facing scarp above crater wall of scoria cone of unit mwy. Steep outcrops are massive and block jointed. Unit is chemically similar to predominant lavas of unit $\mathrm{mns}$ but differs in being plagdominant and richer in total phenocrysts. Phenocrysts: $7-10 \%$ plag (mph to $3 \mathrm{~mm}$ ); $2-3 \%$ olivine (mph to $2 \mathrm{~mm}$ ); some composite intergrowths. Base not exposed. Draped and largely 
concealed by agglutinate of unit mwy. Inferred also to underlie nearby unit mys. Undated [NS]

rct Rhyolite of South Sister climbers trail (late Pleistocene) - Phenocryst-rich pyroxene-rhyolite $\left(72.7-73.4 \% \mathrm{SiO}_{2}\right.$ ) lava flows that emerge from beneath Lewis Glacier moraines high on south slope of South Sister. Main flow apron divides into two lobes that extend $2 \mathrm{~km}$ and $3 \mathrm{~km}$ downslope, respectively, latter of which reaches lowland toe of edifice. Smaller third lobe about $200 \mathrm{~m}$ east of upper end is largely covered by surficial deposits. All exposures are glacially eroded, strongly flow foliated, and widely spherulitic or vitrophyric. Phenocrysts: $7-10 \%$ plag (mph to $3 \mathrm{~mm}$ ); 1\% opx (mph to $0.8 \mathrm{~mm}$, plus rare quench needles $1-2 \mathrm{~mm}$ long); sparse oxide mph. Also contains sparse clots: either all plag, pyroxene-oxide, or plagpyroxene-oxide. Maximum thickness exposed is about $75 \mathrm{~m}$ proximally and about $60 \mathrm{~m}$ at southwestern lowland flow front. Medial exposures are eroded into cliffy ridges where foliation exhibits sweeping ramps and folds. Lowland lobe is heavily mantled by late Holocene pumice-fall deposits associated with unit rrm and is intruded by fissure-aligned minidomes of unit rrm. Overlies units dcg ( $31 \pm 3 \mathrm{ka})$, dmn, dmw, dwp, and rse ( $34 \pm 1 \mathrm{ka})$. Overlain (inferentially) by unit aeg. ${ }^{40} \mathrm{Ar} /{ }^{39} \mathrm{Ar}$ ages: $30 \pm 8 \mathrm{ka}, 24 \pm 5 \mathrm{ka}[\mathrm{SS}]$

rdc Rhyolite of "Devils chain" (late Holocene) - Chain of nearly contiguous, virtually uneroded, rhyolite lava domes (72.3-72.8\% $\mathrm{SiO}_{2} ; \mathrm{n}=31$; see also Scott, 1987), $5 \mathrm{~km}$ long and aligned north-south on southeast apron of South Sister. Chain consists of seven main lavas and several minidomes (Scott, 1987). Three domes issued short coulees; largest coulee is 2-km-long Newberry flow, which accounts for 60 percent of total eruptive volume and, only $2.5 \mathrm{~km}$ from summit of South Sister, is northernmost vent along principal chain. Dike-fed alignment is expressed between domes by fissures and graben cut in 10-m-thick proximal subplinian pumice-fall deposits that preceded effusion of most lavas. Only exception to generality of lavas following fallout is southwest lobe (unit rdc') of Newberry flow, much of which is tephra mantled (white stipple on map). Ejecta ring (black stipple on map) wraps west end of Newberry flow near its vent; ridges of thick ejecta likewise flank chain of four small domes about $1 \mathrm{~km}$ south of Newberry vent, heavily mantling and locally concealing subjacent unit rse. For composite (multivent) subplinian-fall deposit, 10-cm isopach extends 11 $\mathrm{km}$ east and $6 \mathrm{~km}$ south of vent chain, as mapped by Scott (1987), who calculated eruptive (magma) volumes of $0.3 \mathrm{~km}^{3}$ for lavas and $0.02 \mathrm{~km}^{3}$ for tephras (mostly fallout but including thin proximal pyroclastic flows). Unit has sometimes been called "Devils Hill chain," but its name is here shortened to avoid confusion with the (subjacent) Pleistocene rhyolite of Devils Hill (unit rdh). Spring-fed Hell Creek emerges from beneath unit rdh; Satan Creek from beneath this unit. Beyond 3.5-km-long gap north of Newberry flow, second north-south fissure alignment near Carver Lake on north-northeast slope of South Sister is marked by $1.2-\mathrm{km}$-long chain of minor vents that released very small volumes of lava and pumice (Scott, 1987); these, however, are high enough in elevation to have been scoured by Neoglacial ice. Nonetheless, because products of all 20 or so vents (along two chains) are compositionally identical, parallel en echelon chains probably erupted contemporaneously. Thickest exposures are about $120 \mathrm{~m}$ (north side of Newberry flow) and about $50 \mathrm{~m}$ for several southern domes and for small lava flow northwest of Carver Lake. Lavas are either coarsely blocky, dense black vitrophyre or pale gray and vesicular; strongly to weakly flow foliated. Spherulitic layers are rarely exposed, but oxidized rehealed flow-breccia layers are common. Slabby, tan, partly devitrified interior facies is exposed locally on ice-scoured lavas near Carver Lake. For interpretation of brecciated obsidian-bearing margin (largely tephra free) of otherwise tephra-mantled southwest lobe of Newberry flow (unit rdc'), see Scott (1987, his fig. 9). Phenocrysts: $5-7 \%$ plag (mph to $3.5 \mathrm{~mm}$ ); $<1 \%$ opx (mph to 0.7 $\mathrm{mm}$ ); sparse oxide mph; many plag crystals carry prominent melt inclusions, and others are coarsely sieved; unit also contains common plag-pyroxene-oxide clots. ${ }^{14} \mathrm{C}$ age: about 2,000 yr B.P. (Scott, 1987; Sherrod and others, 2004). Unit is younger than all others nearby except Little Ice Age till. Intervening weak soil suggests that pumice fall of this unit postdates that from Rock Mesa (unit rrm) by at least a century (Scott, 1987) [BT, SS]

rdh Rhyolite of Devils Hill (late Pleistocene) - Steep rhyolite (73.4-74.1\% $\mathrm{SiO}_{2}$ ) lava dome that has sprawling flow lobes to south and east; altogether, $2 \mathrm{~km}$ across, having nearly $500 \mathrm{~m}$ of total relief. Dome stands $6 \mathrm{~km}$ south of South Sister summit and is almost everywhere glacially scoured. Lithologically varied: widely vitrophyric, partly glassy or spherulitic; block 
jointed and only locally vesicular or vuggy but pervasively flow foliated; gray to white, only locally oxidized. Little pumiceous carapace preserved except near its summit. Phenocrysts: $3-5 \%$ plag (mph to as big as $3 \mathrm{~mm}$, but few $>1 \mathrm{~mm}$ ); $1-2 \%$ pyroxenes (mostly mph, rarely as long as $1.2 \mathrm{~mm}$ ); sparse oxide $\mathrm{mph}$; sparse clots, either all plag or plag-pyroxene. May be roughly contemporaneous with chemically identical (but phenocryst poorer) adjacent dome of unit rkb. Unit dml (34 $\pm 1 \mathrm{ka})$ banks against and wraps around dome (this unit). Intruded, and overlain by, late Holocene domes of unit rdc. Overlain by fallout associated with units rdc, rrm, and btk. ${ }^{40} \mathrm{Ar} /{ }^{39} \mathrm{Ar}$ age: $34.8 \pm 1.5 \mathrm{ka}[\mathrm{BT}, \mathrm{SS}]$

rgl Rhyolite of Green Lakes (late Pleistocene) - Rhyolite $\left(72.2-72.9 \% \mathrm{SiO}_{2}\right)$ lava dome partly buried by dacite lava flows (unit dgl) at east toe of South Sister edifice, just west of Green Lakes. Exposure is $700 \mathrm{~m}$ long and $150 \mathrm{~m}$ high. Glacially eroded, flow-foliated lava varies from dark-gray vitrophyre to pale-gray felsite, partly devitrified and locally spherulitic; widely vesicular or vuggy. Jointing causes rock to break into chunks or blocks. Phenocrysts: $5-7 \%$ plag (mph to as big as $3 \mathrm{~mm}$ ); 1\% pyroxenes (mph to $0.5 \mathrm{~mm}$, plus rare rods to 1 $\mathrm{mm}$ long); sparse oxide $\mathrm{mph}$; also contains common plag-pyroxene-oxide clots. Base not exposed. Overlain by South Sister lavas of unit dgl. ${ }^{40} \mathrm{Ar} /{ }^{39} \mathrm{Ar}$ age: $31.9 \pm 0.7 \mathrm{ka}$ [BT]

rkb Rhyolite of Kaleetan Butte (late Pleistocene) - Rhyolite (73.5-73.6\% $\mathrm{SiO}_{2}$ ) dome-flow complex adjacent to west side of Devils Hill dome (unit rdh) and $6 \mathrm{~km}$ south of South Sister summit. Complex is $2 \mathrm{~km}$ wide and has $320 \mathrm{~m}$ of relief on its steep south side. East and west lobes are compositionally identical but may have extruded independently; also is chemically similar to adjacent Devils Hill dome (unit rdh) but carries fewer phenocrysts. Glacially scoured surface consists largely of flow-foliated vitrophyre, although partially devitrified layers locally alternate with obsidian and spherulitic lenses; commonly is finely vesicular but only locally is oxidized streaky pink. Deeper erosion has exposed ledges of thinly platy felsitic interior on steep southeast face. Phenocrysts: $2-3 \%$ plag (mph to $1 \mathrm{~mm}$ ); $<1 \%$ opx (all mph); sparse plag-opx clots. Abuts the (chemically identical) rhyolite of Devils Hill (unit rdh); units may be roughly contemporaneous, but age relation is not clear at contact. Overlies unit dwp ( $34 \pm 3 \mathrm{ka})$. Unit dml ( $34 \pm 1 \mathrm{ka})$ banks against northeast margin of dome; west side of dome is wrapped by postglacial mafic lava flows from Le Conte Crater (unit $\mathrm{mlc}$ ). K-Ar age: $30 \pm 5 \mathrm{ka}$ [SS]

rmc Rhyolite of Mesa Creek (late Pleistocene) - Moderately phenocryst-rich rhyolite (72.3-72.6\% $\mathrm{SiO}_{2}$ ) lava flow or lobe of partly buried lava dome exposed for $800 \mathrm{~m}$ along uppermost Mesa Creek at southwest toe of South Sister. Flow direction was toward southwest, down steep slope; exposed relief is about $340 \mathrm{~m}$, but true thickness probably is only about $150 \mathrm{~m}$. Glaciated south cliffs are pervasively flow foliated, exposing black vitrophyre, vesicular and oxidized layers, and zones of platy felsite. Ice-scoured lava benches above are variably devitrified and mostly medium gray, weathering cream to pale gray. Phenocrysts: $5-7 \%$ plag (mph to $2 \mathrm{~mm}$ ), some slightly rounded; $<<1 \%$ opx ( $\mathrm{mph}$, rarely as big as $0.6 \mathrm{~mm}$, plus rare rods 0.2 by $3 \mathrm{~mm}$ ); still sparser hornblende ( $\mathrm{mph}$ to $0.7 \mathrm{~mm}$, along with tiny needles), mostly opacitized; sparse oxide mph. Normal magnetic polarity (laboratory determination by D.E. Champion, 2006). Overlain, and extensively buried, by South Sister lava flows of unit dcg ( $31 \pm 3 \mathrm{ka}$ ); coulee of postglacial unit rrm banks against it. ${ }^{40} \mathrm{Ar} /{ }^{39} \mathrm{Ar}$ ages: $47 \pm 8 \mathrm{ka}$, $45 \pm 15 \mathrm{ka}[\mathrm{SS}]$

roc Rhyolite of Obsidian Cliffs (late Pleistocene) - High-silica rhyolite (76.4-76.7\% $\mathrm{SiO}_{2}$ ) coulee that emerges from beneath younger lavas of Middle Sister edifice about $3 \mathrm{~km}$ northwest of its summit and extends $3 \mathrm{~km}$ farther northwest. Everywhere glacially scoured, flow is $1 \mathrm{~km}$ wide and as thick as $120 \mathrm{~m}$ near Obsidian Falls and $135 \mathrm{~m}$ at its distal flow front. Aphyric lava is strongly flow foliated and ranges from black obsidian to white felsite, some layers being vesicular or oxidized. Unit is most silicic Quaternary lava in Oregon Cascade Range. Phenocrysts: strictly aphyric. Overlies units mlb (47-49 ka) and aoc ( $48 \mathrm{ka})$. Syneruptive lapilli-fall deposit (white stipple on map) containing clasts of aphyric pumice, obsidian, and

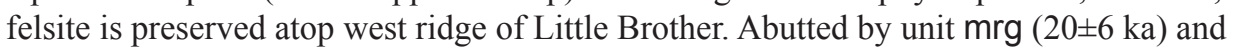
wrapped by Holocene lava flows from Collier Cone (unit acc). Overlain near Sister Spring by thick lava of unit dss ( $25 \pm 3 \mathrm{ka}$ ), which drapes down across successive lithologic zones in rhyolite of this unit. ${ }^{40} \mathrm{Ar} /{ }^{\beta 9} \mathrm{Ar}$ age: $37.8 \pm 1.8 \mathrm{ka}$ [NS]

rpc Rhyolite of Park Creek (late Pleistocene) - Moderately porphyritic, glaciated rhyolitic (72.5\% $\mathrm{SiO}_{2}$ ) lava flow that crops out as single 30 -m-high bench (less than 100 by $350 \mathrm{~m}$ ) on north 
wall of West Fork Park Creek at about 7,000 ft elevation (UTM grid 014/852). Flowfoliated lava is dominantly black vitrophyre but includes layers and lenses of gray or pink felsite, some strongly spherulitic, and thin shear zones of pink to brick-red breccia. Phenocrysts: $5-7 \%$ plag $(0.5-2 \mathrm{~mm}) ;<1 \%$ opx $(0.1-0.5 \mathrm{~mm})$; sparse oxide mph. Base not exposed. Overlain by unit drm (29 $\pm 1 \mathrm{ka})$; unit awf ( $24 \pm 1 \mathrm{ka})$ banks against base of unit [BT]

rpg Rhyodacite of Prouty Glacier (late Pleistocene)—Rhyodacitic (68.1-68.4\% $\mathrm{SiO}_{2}$ ) lava flow high on South Sister edifice, cropping out principally as prominent ledge that wraps northwest corner of headwall of Prouty Glacier, 0 to $20 \mathrm{~m}$ above ice surface. At 9,300 ft elevation, this is highest exposure on South Sister edifice of any lava flow that is more silicic than dacite. Glacially eroded, slabby lava is exposed laterally for about $500 \mathrm{~m}$; lava generally is about $10 \mathrm{~m}$ thick, thickening northward where it disappears beneath younger units. Locally vesicular to vuggy and has pink oxidized films along joint planes. Second outcrop, compositionally identical, is exposed through Little Ice Age moraines about $500 \mathrm{~m}$ east of terminus of Prouty Glacier as narrow, 300-m-long, ice-sculpted, northeast-trending rib of massive to vuggy gray lava (at about 7,900 ft elevation, $500 \mathrm{~m}$ southeast of Carver Lake; UTM grid 001/846). Phenocrysts: $~ 5 \%$ plag (mph to $2 \mathrm{~mm}$, plus rare antecrysts to $8 \mathrm{~mm}$ long); $<1 \%$ pyroxenes (mph to $0.7 \mathrm{~mm}$, nearly all in clots with plag and oxides); $<1 \%$ hornblende $(0.1-1$ $\mathrm{mm}$ long, mostly opacitized); sparse oxide $\mathrm{mph}$; also contains sparse plag-pyroxene-oxide clots, plag-bearing mafic blebs (as big as $5 \mathrm{~mm}$ ), and olivine xenocrysts $(0.1-0.5 \mathrm{~mm}$ ). Underlain on Prouty Glacier headwall by units aph and aph'; overlain there by unit dpg,

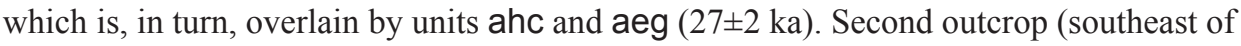
Carver Lake) is overlain by unit drm $(29 \pm 1 \mathrm{ka}) \cdot{ }^{40} \mathrm{Ar} /{ }^{39} \mathrm{Ar}$ age: $32.8 \pm 1.5 \mathrm{ka}$ [BT, SS] see also Scott, 1987) coulee, associated subplinian pumice-fall deposits, and nearby chain of satellitic minidomes. Virtually uneroded coulee is 2 by $3 \mathrm{~km}$ in diameter, $50 \mathrm{~m}$ thick at most margins, and as thick as $85 \mathrm{~m}$ at northwest terminus where descent into Mesa Creek stalled. Small early lava lobe spread northeast, but main outflow was south, southwest, and northwest from vent. Broad swell over vent is $320 \mathrm{~m}$ higher than northwest terminus of coulee. Lava is strongly blocky and has steep flow fronts, consisting principally of dense to pumiceous, flow-foliated vitrophyre. Stratified pumice-fall deposit is more than $10 \mathrm{~m}$ thick proximally and includes agglutinate locally exposed along gullies. Its $10-\mathrm{cm}$ isopach extends $17 \mathrm{~km}$ east and $13 \mathrm{~km}$ south of vent, as mapped by Scott (1987), who calculated eruptive (magma) volumes of $0.5 \mathrm{~km}^{3}$ for lava and $0.03 \mathrm{~km}^{3}$ for tephra (mostly fallout but also includes 1-m-thick pyroclastic flows that extend as far as $1 \mathrm{~km}$ ); traces of ash are recognized as far as $30 \mathrm{~km}$ downwind. About $1 \mathrm{~km}$ east of principal vent, a fissure vent aligned N. $5^{\circ}$ to $10^{\circ}$ E. ("Rock Mesa ENE" assemblage of Scott, 1987) produced 200-m-wide dome, as well as several tiny extrusions only meters across, modest ejecta rings, and small volumes of pumiceous fallout and pyroclastic flows. Eruptive reach of fissure system is about $500 \mathrm{~m}$ long, but fractures and graben continue for another $700 \mathrm{~m}$ northward across previously glaciated surface of unit dcg. Main ejecta ring around fissure-vent system heavily blankets and widely obscures subjacent unit rct. Lavas of fissure-vent system are uneroded, flow foliated, and coarsely blocky, having coarsely to finely pumiceous surfaces. Products of coulee and fissure are compositionally identical. Phenocrysts: 5-7\% plag ( $\mathrm{mph}$ to $2 \mathrm{~mm}$ ), many slightly rounded; $<1 \%$ opx (mph only); trace amounts of hornblende and oxide mph; also contains sparse plag-opx-oxide clots. ${ }^{14} \mathrm{C}$ age: $2,150 \pm 150$ yr B.P. (preferred age of Scott, 1987). Younger than all nearby units except rdc, fallout of which overlies weak soil developed atop fallout of this unit, which may, thus, be a century or more older (Scott, 1987) [SS]

rsc Rhyolite of Separation Creek (late Pleistocene)—Rhyolite (69.6-73.9\% $\mathrm{SiO}_{2}$ ) of Dome 7930 just west of Chambers Lakes in saddle between Middle Sister and South Sister, about $2.5 \mathrm{~km}$ from summit of each. Steep, compact, glacially scoured dome is $1 \mathrm{~km}$ in diameter and has $350 \mathrm{~m}$ of relief. Most exposures are flow-foliated, dark- or medium-gray vitrophyre, dense or pumiceous, and eroded into hackly jointed knobs and ledges. Some layers are vuggy or oxidized, and many joints have pink oxidation films. Pale-gray, devitrified, slabby interior crops out locally. Apparent chemical heterogeneity may reflect disaggregation and dispersal of material from relatively mafic, phenocryst-poor enclaves, 1 to $20 \mathrm{~cm}$ across and ovoid or crenulate. Phenocrysts: $2-3 \%$ plag (mph to $2.5 \mathrm{~mm}$ ); $<1 \%$ pyroxenes (mph to $0.7 \mathrm{~mm}$, 
mostly in clots with plag and oxides); trace amounts of hornblende $(0.1-0.7 \mathrm{~mm})$, rims opacitized; sparse oxide mph. At southwest toe of dome, what appears to be early lobe of this unit (subunit rsc'; 72.3\% $\mathrm{SiO}_{2}$ ) differs in that it contains larger feldspar phenocrysts, some as big as $8 \mathrm{~mm}$. Overlies distal flows of units aeg (here, $27 \pm 3 \mathrm{ka})$ and alg $(27 \pm 1 \mathrm{ka})$ at Separation Creek. Dome is wrapped by two tongues of dacite coulee of unit dig (14 $\pm 3 \mathrm{ka})$.

${ }^{40} \mathrm{Ar} /{ }^{39} \mathrm{Ar}$ age: $25.4 \pm 1.3 \mathrm{ka}$ [NS, SS]

rse

rsf

rsg

rsw

Rhyolite southeast of Lewis Glacier (late Pleistocene) - Phenocryst-poor rhyolite (73.6-74.0\% $\mathrm{SiO}_{2}$ ) lava flows on south slope of South Sister. Flows extend $2.5 \mathrm{~km}$ southward from exposures as high as $8,050 \mathrm{ft}$ elevation along recently deglaciated trough of Lewis Glacier to eroded flow fronts as low as 6,500 ft (northeast of Moraine Lake) and 6,400 ft (just south of Newberry flow, unit rdc). All exposures are glacially scoured, and some are deeply incised. Two flow units are exposed on glaciated cliff just north of vent for Newberry flow, which overran their southeast apron. Nearly all exposures are flow foliated, whether glassy or devitrified. Unit is lithologically varied, from massive, block-jointed or platy, white felsite to pale-gray, micropumiceous or dark-gray, dense vitrophyre; oxidized layers and breccia zones are not uncommon. Fused rheomorphic flow breccia crops out near base of unit both north and south of Newberry flow. Phenocrysts: $1-2 \%$ plag (mph, rarely as big as $1.5 \mathrm{~mm}) ;<<1 \%$ opx (all $\mathrm{mph}$ ); $<<1 \%$ hornblende ( $\mathrm{mph}$ to as long as $1 \mathrm{~mm})$; sparse oxide mph $(0.1-0.2$ $\mathrm{mm})$. Overlies units asn and $\mathrm{dml}(34 \pm 1 \mathrm{ka})$. Overlain by units $\mathrm{dmn}(28 \pm 1 \mathrm{ka}, 25 \pm 1 \mathrm{ka})$ and rct (30 $\pm 8 \mathrm{ka}, 24 \pm 5 \mathrm{ka}$ ); intruded, and overlain, by several domes of unit rdc and heavily mantled and widely concealed by proximal pumice falls that preceded extrusion of those domes. ${ }^{40} \mathrm{Ar} /{ }^{\beta 9} \mathrm{Ar}$ ages: $35.0 \pm 2.7 \mathrm{ka}, 33.6 \pm 0.5 \mathrm{ka}$ [BT, SS]

Rhyolite of South Fork Whychus Creek (late Pleistocene) - Large rhyolite (73.8-74.4\% $\mathrm{SiO}_{2}$ ) coulee on lower northeast flank of South Sister that extends from just north of Carver Lake for $3 \mathrm{~km}$ east along Whychus Creek drainage. Glacially scoured coulee is about 1 $\mathrm{km}$ wide and as thick as $300 \mathrm{~m}$ proximally, where three (compositionally identical) flow units are locally discernible; unit is $150 \mathrm{~m}$ thick at its northeast lowland terminus. Vertical jointing prominent in high vent region; flow foliated elsewhere, commonly convolutely. Lithologically varied, from dense vitrophyre or obsidian to platy, slabby, or block-jointed felsite, in addition to local spherulitic zones and oxidized flow-breccia zones. Extensive vitrophyre preserved atop flow where only lightly scoured by ice. Phenocrysts: widely aphyric, but locally has $<1 \%$ plag (generally $\leq 1 \mathrm{~mm}$ ) and rare opx mph; in thin section, rare rounded or partly resorbed plag grains $(0.2-1 \mathrm{~mm})$ are probably antecrysts. Overlies unit $\mathrm{mdl}(181 \pm 21 \mathrm{ka})$. Overlain by unit aeg (here, $27 \pm 2 \mathrm{ka}$ ) and is wrapped by units dcn, drm ( $29 \pm 1 \mathrm{ka})$, and $\mathrm{mcl} .{ }^{40} \mathrm{Ar}{ }^{39} \mathrm{Ar}$ age: $35.8 \pm 2.0 \mathrm{ka}$ [BT, NS, SS, TCB]

Rhyodacite southwest of Golden Lake (late or middle Pleistocene) - Rhyodacite (70.1\% $\left.\mathrm{SiO}_{2}\right)$ plug that intrudes brick-red mafic $\left(56.5 \% \mathrm{SiO}_{2}\right)$ scoria cone of unit mbt at elevation of 7,150 ft on distal nose of northwest ridge of Broken Top volcano, $1 \mathrm{~km}$ southwest of Golden Lake. Glaciated plug is only $70 \mathrm{~m}$ in diameter; its finely crystalline interior is block jointed or slabby to platy, is variably mottled in shades of gray, and has sparse irregular vugs. Locally black, glassy or aphanitic at its margins, plug intrudes and fuses adjacent red scoriae. Phenocrysts: $3-5 \%$ plag ( $\mathrm{mph}$ to $1 \mathrm{~mm}$, rarely as big as $4 \mathrm{~mm}$ ); $<1 \%$ pyroxenes $(0.2-0.4 \mathrm{~mm}$, rarely as large as $0.8 \mathrm{~mm})$; sparse oxide $\mathrm{mph}$; contains sparse clots, either all plag or plag-pyroxene-oxide. No associated lava flows are preserved. Taylor (1978) suggested that thick stratified pumice-fall deposit preserved atop same ridgecrest about $1 \mathrm{~km}$ southeast is correlative with compositionally similar plug; if so, plug may be late Pleistocene and, thus, related magmatically to nearby South Sister rather than to much older Broken Top. Ridge hosting scoria cone and rhyodacite plug consists of middle Pleistocene stack of mafic lava flows that erupted at Broken Top. Undated [BT]

Rhyolite southwest of Lewis Glacier (late Pleistocene)—Phenocryst-poor rhyolite (73.3, $73.6 \% \mathrm{SiO}_{2}$ ) lava exposed only in two small windows on south flank of South Sister. Upper one is cliffy knob that has $150 \mathrm{~m}$ of relief, its top at elevation $8,550 \mathrm{ft}$ on south end of cleaver between Clark and Lewis Glaciers; remnant of possible vent dome, it sheds large talus. Lower exposure about $1 \mathrm{~km}$ southwest is 150 -m-long window incised through apron of unit dcg lavas by uppermost tributary of Mesa Creek. Phenocrysts: 1-2\% plag (mph to $1 \mathrm{~mm}$ ); $<<1 \%$ opx (all mph). Contrasts with nearby crystal-rich rhyolite units rct and rmc, just east and west. Glacially eroded, flow foliated, varying from coarsely block jointed and 
massive to slightly vesicular; mostly gray or grayish brown, weathering pale gray or purplish brown. Obsidian widespread in lower window. Base not exposed. Underlies units dcg ( $31 \pm 3$ ka) and aeg. ${ }^{40} \mathrm{Ar} /{ }^{39} \mathrm{Ar}$ age: $51 \pm 10 \mathrm{ka}[\mathrm{SS}]$

rtl Rhyodacite southwest of Todd Lake (middle Pleistocene) - Glaciated rhyodacite lava dome (69.4\% $\mathrm{SiO}_{2}$; see Taylor, 1978) above southwest shoreline of Todd Lake. Dome is $500 \mathrm{~m}$ wide, $100 \mathrm{~m}$ high, and part of cluster of such silicic lavas that extends east and northeast of lake (Taylor, 1978). Scattered outcrops through extensive colluvium are mostly gray or pink felsite and local remnants of black vitrophyre. Phenocrysts: 5-10\% plag $(0.5-3 \mathrm{~mm}) ; \sim 1 \%$ opx and $<1 \%$ cpx (each mph to $1 \mathrm{~mm}$ ). Abutted by younger lavas of unit mbl. Undated [BT]

ruc Rhyodacite of Upper Chush Falls (middle Pleistocene) - Rhyodacite (69.1-69.7\% $\mathrm{SiO}_{2}$ ) coulee as thick as $110 \mathrm{~m}$ and as wide as $1.5 \mathrm{~km}$ that crops out 5 to $7 \mathrm{~km}$ north of Broken Top volcano. Supports spectacular waterfalls on forks of both Park and Whychus Creeks, along which strongly flow-foliated felsites form gorge walls. Rocks are partly glassy or devitrified and block jointed or slabby to platy; foliation is locally convolute. Rarely exposed base of glaciated flow consists of massive or slabby black glass and flow breccia. Phenocrysts: $2-3 \%$ plag (mph to $1 \mathrm{~mm}$, rarely $2 \mathrm{~mm}$ ); $<1 \%$ pyroxenes (all $\mathrm{mph}$ ); sparse oxide $\mathrm{mph}$. Overlies unit bwy. Overlain by avalanche and glacial deposits and mafic lava flows, all derived from Broken Top, and by unit apc ( $31 \pm 9 \mathrm{ka})$ and probably by unit drm $(29 \pm 1 \mathrm{ka})$. Coulee may represent part of silicic eruptive interval that produced similar pyroxene rhyodacites of Tam McArthur Rim, about $6 \mathrm{~km}$ southeast. ${ }^{40} \mathrm{Ar} /{ }^{39} \mathrm{Ar}$ age: $169.3 \pm 2.1 \mathrm{ka}$ [TCB]

r58 Rhyolite of Dome 5803 (late Pleistocene) — Aphyric rhyolite $\left(74.0 \% \mathrm{SiO}_{2}\right)$ lava dome centered $7.5 \mathrm{~km}$ northwest of North Sister and $700 \mathrm{~m}$ southeast of Condon Butte. Compact dome is $300 \mathrm{~m}$ in diameter, $60 \mathrm{~m}$ high, glacially stripped of its glassy vesicular carapace, and strewn with erratics of mafic lavas. Consists of dense, fine-grained felsite, pale gray to cream white, that splits platy, chunky, or into small blocks. Obsidian and flow-foliated glassy blocks were found only in colluvium on slopes of dome. Overlies apron of uncorrelated glaciated mafic lavas. Abutted by lava flow from andesitic Four in One Cone (about $2 \mathrm{ka}$; Sherrod and others, 2004). Located $4 \mathrm{~km}$ north of Obsidian Cliffs (unit roc; $38 \pm 2 \mathrm{ka}$ ), Dome 5803 is northwesternmost unit in belt of rhyolites for which age of onset has propagated northwestward across Oregon since middle Miocene (MacLeod and others, 1975). ${ }^{40} \mathrm{Ar} /{ }^{39} \mathrm{Ar}$ age: $40.4 \pm 1.4 \mathrm{ka}[\mathrm{NS}]$

spt Shevlin Park Tuff (middle Pleistocene) - Compositionally heterogeneous andesite-dacite ignimbrite that (within map area) crops out only along 800-m-long reach of North Fork Whychus Creek (UTM grid 050/902), ending about $1 \mathrm{~km}$ upstream from confluence with South Fork Whychus Creek. Outcrop is westernmost exposure of widespread ash-flow sheet that extends about $30 \mathrm{~km}$ southeast to city of Bend and as far as toe of Newberry Volcano. Regionally, multiflow, simple cooling unit typically is dark gray, nonwelded to modestly sintered but locally is densely welded; tuff is seriate from gritty matrix to large scoria blocks. Unit fills dissected paleotopography, ranging in thickness from a few meters on plateaus to as much as $45 \mathrm{~m}$ along paleovalleys (Taylor, 1981; Mimura, 1984, 1992; Sherrod and others, 2004). Juvenile scoriae predominantly are black, range from 55 to $62 \% \mathrm{SiO}_{2}$, and contain only about $1 \%$ plag and traces of opx, cpx, oxides, and olivine; sparse white to buff pumices range in composition from 64 to $68.5 \% \mathrm{SiO}_{2}$ and contain same phenocryst suite minus olivine (Conrey and others, 2001a). Maximum thickness along North Fork Whychus Creek is $18 \mathrm{~m}$. Except for basal $1 \mathrm{~m}$, unit is unstratified, nongraded, fines poor, rich in scoria lapilli and blocks, and indurated though nonwelded; basal $1 \mathrm{~m}$ is sintered and locally eutaxitic, having black fiamme. Largest black scoriae here are 20 to $35 \mathrm{~cm}$, and largest white pumice clasts are about $5 \mathrm{~cm}$; latter make up only 1 to $2 \%$ of juvenile lapilli and are virtually absent in lower third of deposit. Accidental lithic fragments are nearly all sparsely or moderately porphyritic, mafic and intermediate lavas, mostly 1 to $4 \mathrm{~cm}$ and as big as $6 \mathrm{~cm}$; lithic fragments are sparse in upper parts of deposit but are as abundant as $5 \%$ in its basal few meters. Upper half of deposit is dark gray, but much of lower half is oxidized brick red. Northward direction of flow at this site was suggested by Mimura (1984) on basis of weak imbrication of clasts. Overlain directly by lava flow of unit mws $(175 \pm 3 \mathrm{ka})$. Base of ignimbrite rests on fine-grained paleosol, dark gray to reddish brown and 6 to $20 \mathrm{~cm}$ thick. Beneath paleosol, in descending sequence, are following subunits (not possible to represent separately at scale of map): 
(a) Unstratified dacitic scoria fall, brick red, 30 to $70 \mathrm{~cm}$ thick, and well sorted; most scoriae are 1 to $2 \mathrm{~cm}$ across, and largest is $4 \mathrm{~cm}$.

(b) Dacitic nonwelded ash-flow deposit, about $4 \mathrm{~m}$ thick, cream to tan, containing sparse tan crystal-poor pumice clasts as big as $5 \mathrm{~cm}$; separable into three flow units by thin lithic-concentration zones; plag separated from juvenile pumice yielded ${ }^{40} \mathrm{Ar} /{ }^{39} \mathrm{Ar}$ age of $225 \pm 10 \mathrm{ka}$.

(c) Reworked stratified interval of sand and gravel as thick as $4 \mathrm{~m}$, including channel fill cut into underlying diamict, which supplied most of reworked clasts.

(d) Massive diamict, gray to ochre, fines poor, more than $5 \mathrm{~m}$ thick (base not exposed) marked by vague internal shear planes and dominated by angular blocks of crystalrich mafic lava (in addition to subordinate crystal-poor lavas), mostly smaller than $30 \mathrm{~cm}$ but some as big as $1.5 \mathrm{~m}$, nearly all densely nonvesicular and many glassy. Exposed only at this site, subunit may be block-and-ash-flow deposit or its streammodified successor.

(e) Glaciated lava of unit mwh (195 $\pm 5 \mathrm{ka})$ crops out at stream level about $400 \mathrm{~m}$ downstream from section described but is not exposed between them.

With these stratigraphic constraints, Shevlin Park Tuff is now bracketed in age between $225 \pm 10 \mathrm{ka}$ and $175 \pm 3 \mathrm{ka}$, most likely between $195 \pm 5 \mathrm{ka}$ and $175 \pm 3 \mathrm{ka}$; this requires that unit be younger than published plag ${ }^{40} \mathrm{Ar} /{ }^{39} \mathrm{Ar}$ age of $260 \pm 15 \mathrm{ka}$ (Lanphere and others, 1999) [TCB]

\section{References Cited}

Arculus, R.J., 2003, Use and abuse of the terms calcalkaline and calcalkalic: Journal of Petrology, v. 44, p. 929-935.

Atwater, T., 1970, Implications of plate tectonics for the Cenozoic evolution of western North America: Geological Society of America Bulletin, v. 81. p. 3,513-3,536.

Bacon, C.R., 1985, Implications of silicic vent patterns for the presence of large crustal magma chambers: Journal of Geophysical Research, v. 90, p. 11,243-11,252.

Borg, L.E., and Clynne, M.A., 1998, The petrogenesis of felsic calc-alkaline magmas from the southernmost Cascades, California - Origin by partial melting of basaltic lower crust: Journal of Petrology, v. 39, p. 1,197-1,222.

Bostock, M.G., Hyndman, R.D., Rondenay, S., and Peacock, S.M., 2002, An inverted continental Moho and serpentinization of the forearc mantle: Nature, v. 417, p. 536-538.

Bullen, T.D., and Clynne, M.A., 1990, Trace element and isotopic constraints on magmatic evolution at Lassen volcanic center: Journal of Geophysical Research, v. 95, p. 19,671-19,691.

Calvert, A., and Lanphere, M., 2006, Argon geochronology of Kilauea's early submarine history: Journal of Volcanology and Geothermal Research, v. 151, p. 1-18.

Carmichael, I.S.E., 1964, The petrology of Thingmuli, a Tertiary volcano in eastern Iceland: Journal of Petrology, v. 5, p. 435-460.

Christiansen, R.L., Foulger, G.R., and Evans, J.R., 2002, Uppermantle origin of the Yellowstone hotspot: Geological
Society of America Bulletin, v. 114, p. 1,245-1,256.

Christiansen, R.L., and McKee, E.H., 1978, Late Cenozoic volcanic and tectonic evolution of the Great Basin and Columbia Intermontane region, in Smith, R.B., and Eaton, G.P., eds., Cenozoic tectonics and regional geophysics of the western Cordillera: Geological Society of America Memoir 152, p. 283-312.

Clark, J.G., 1983, Geology and petrology of South Sister volcano, High Cascade Range, Oregon: Eugene, University of Oregon, Ph.D. dissertation, 235 p.

Conrey, R.M., Donnelly-Nolan, J., Taylor, E.M., Champion, D., and Bullen, T., 2001a, The Shevlin Park Tuff, central Oregon Cascades Range-Magmatic processes recorded in an arc-related ash-flow tuff: Eos, Transactions, American Geophysical Union, v. 82, no. 47, Fall Meeting Supplement, Abstract V32D-0994.

Conrey, R.M., Hooper, P.R., Larson, P.B., Chesley, J., and Ruiz, J., 2001b, Trace element and isotopic evidence for two types of crustal melting beneath a High Cascade volcanic center, Mt. Jefferson, Oregon: Contributions to Mineralogy and Petrology, v. 141, p. 710-732.

Conrey, R.M., Sherrod, D.R., Hooper, P.R., and Swanson, D.A., 1997, Diverse primitive magmas in the Cascade arc, northern Oregon and southern Washington: Canadian Mineralogist, v. 35, p. 367-396.

Conrey, R.M., Taylor, E.M., Donnelly-Nolan, J., and Sherrod, D.R., 2002, North-central Oregon Cascades_-Exploring petrologic and tectonic intimacy in a propagating intra-arc rift, in Moore, G.W., ed., Field guide to geologic processes 
in Cascadia: Oregon Department of Geology and Mineral Industries, Special Paper 36, p. 47-90.

Crosson, R.S., and Owens, T.J., 1987, Slab geometry of the Cascadia subduction zone beneath Washington from earthquake hypocenters and teleseismic converted waves: Geophysical Research Letters, v. 14, p. 824-827.

Dixon, T.H., Miller, M., Farina, F., Wang, H., and Johnson, D., 2000, Present-day motion of the Sierra Nevada block and some tectonic implications for the Basin and Range province, North American Cordillera: Tectonics, v. 19 , p. $1-24$.

Driedger, C.L., and Kennard, P.M., 1986, Ice volumes on Cascade volcanoes-Mount Rainier, Mount Hood, Three Sisters, and Mount Shasta: U.S. Geological Survey Professional Paper 1365, 29 p.

Dzurisin, D., Lisowski, M., and Wicks, C.W., 2009, Continuing inflation at Three Sisters volcanic center, central Oregon Cascade Range, USA, from GPS, leveling, and InSAR observations: Bulletin of Volcanology, v. 71, p. $1,091-1,110$.

Dzurisin, D., Lisowski, M., Wicks, C.W., Poland, M.P., and Endo, E.T., 2006, Geodetic observations and modeling of magmatic inflation at the Three Sisters volcanic center, central Oregon Cascade Range, USA: Journal of Volcanology and Geothermal Research, v. 150, p. 35-54.

Evans, W.C., van Soest, M.C., Mariner, R.H., Hurwitz, S., Ingebritsen, S.E., Wicks, C.W., Jr., and Schmidt, M.E., 2004, Magmatic intrusion west of Three Sisters, central Oregon, USA-The perspective from spring geochemistry: Geology, v. 32, no. 1, p. 69-72.

Gardner, C.A., 1994, Temporal, spatial, and petrologic variations of lava flows from the Mount Bachelor volcanic chain, central Oregon High Cascades: U.S. Geological Survey Open-File Report 94-261, 100 p.

Gardner, C.A., Hill, B.E., Negrini, R.M., and Sarna-Wojcicki, A.M., 1992, Paleomagnetic correlation of middle Pleistocene ignimbrites from the Bend, Oregon, area with distal tephra beds: Geological Society of America Abstracts with Programs, v. 24, no. 5, p. 26.

Gill, J.B., 1981, Orogenic andesites and plate tectonics: Berlin, Springer-Verlag, $390 \mathrm{p}$.

Gradstein, F.M., Ogg, J.G., Smith, A.G., Bleeker, W., and Lourens, L.J., 2004, A new geologic time scale, with special reference to Precambrian and Neogene: Episodes, v. 27, p. 83-100.

Green, N.L., 1994, Mechanism for middle to upper crustal contamination: Geology, v. 22, p. 231-234.

Grubensky, M.J., Smith, G.A., and Geissman, G.W., 1998, Field and paleomagnetic characterization of lithic and scoriaceous breccias at Pleistocene Broken Top volcano, Oregon Cascades: Journal of Volcanology and Geothermal Research, v. 83, p. 93-114.

Hammond, W.C., and Thatcher, W., 2004, Contemporary tectonic deformation of the Basin and Range province, western United States - 10 years of observation with the Global Positioning System: Journal of Geophysical Research, v. 109, B08403, $21 \mathrm{p}$.
Harris, R.A., Iyer, H.M., and Dawson, P.B., 1991, Imaging the Juan de Fuca plate beneath southern Oregon using teleseismic P wave residuals: Journal of Geophysical Research, v. 96 , p. $19,879-19,889$.

Hildreth, W., 2004, Volcanological perspectives on Long Valley, Mammoth Mountain, and Mono Craters-Several contiguous but discrete systems: Journal of Volcanology and Geothermal Research, v. 136, p. 169-198.

Hildreth, W., 2007, Quaternary magmatism in the CascadesGeologic perspectives: U.S. Geological Survey Professional Paper 1744, 125 p., available at http://pubs. usgs.gov/pp/pp1744/.

Hildreth, W., Fierstein, J., and Calvert, A.T., 2007, Blue Mountain and The Gas Rocks-Rear-arc dome clusters on the Alaska Peninsula: U.S. Geological Survey Professional Paper 1739-A, 27 p., available at http://pubs.usgs.gov/pp/ pp1739/a/.

Hildreth, W., and Lanphere, M.A., 1994, Potassium-argon geochronology of a basalt-andesite-dacite arc system-The Mount Adams volcanic field, Cascade Range of southern Washington: Geological Society of America Bulletin, v. 106, p. $1,413-1,429$.

Hildreth, W., and Moorbath, S., 1988, Crustal contributions to arc magmatism in the Andes of central Chile: Contributions to Mineralogy and Petrology, v. 98, p. 455-489.

Hill, B.E., 1991, Petrogenesis of compositionally distinct silicic volcanoes in the Three Sisters region of the Oregon Cascade Range-Effects of crustal extension on the development of continental arc silicic magmatism: Corvallis, Oregon State University, Ph.D. dissertation, 247 p.

Hill, B.E., and Taylor, E.M., 1990, Oregon central High Cascade pyroclastic units in the vicinity of Bend, Oregon: Oregon Geology, v. 52, no. 6, p. 125-126, 139-140.

Hodge, E.T., 1925, Mount Multnomah, ancient ancestor of the Three Sisters: University of Oregon Publications, v. 2, no. $10,160 \mathrm{p}$.

Hughes, S.S., 1990, Mafic magmatism and associated tectonism of the central High Cascade Range, Oregon: Journal of Geophysical Research, v. 95, p. 19,623-19,638.

Hughes, S.S., and Taylor, E.M., 1986, Geochemistry, petrogenesis, and tectonic implications of central High Cascade mafic platform lavas: Geological Society of America Bulletin, v. 97, p. 1,024-1,036.

Jones, C.H., Unruh, J.R., and Sonder, L.J., 1996, The role of gravitational potential energy in active deformation in the southwestern United States: Nature, v. 381, p. 37-41.

Jordan, B.T., Grunder, A.L., Duncan, R.A., and Deino, A.L., 2004, Geochronology of age-progressive volcanism of the Oregon High Lava Plains-Implications for the plume interpretation of Yellowstone: Journal of Geophysical Research, v. 109, B10202, doi:10.1029/2003JB002776.

Lanphere, M.A., Champion, D.E., Christiansen, R.L., DonnellyNolan, J.M., Fleck, R.J., and Sarna-Wojcicki, A.M., 1999, Evolution of tephra dating in the western United States: Geological Society of America Abstracts with Programs, v. 31, no. 6, p. A-73. 
Lawrence, R.D., 1976, Strike-slip faulting terminates the Basin and Range province in Oregon: Geological Society of America Bulletin, v. 87, p. 846-850.

Leaver, D.S., Mooney, W.D., and Kohler, W.M., 1984, A seismic refraction study of the Oregon Cascades: Journal of Geophysical Research, v. 89, p. 3,121-3,134.

LeBas, M.J., LeMaitre, R.W., Streckeisen, A., and Zanettin, B., 1986, A chemical classification of volcanic rocks based on the total alkali-silica diagram: Journal of Petrology, v. 27, p. 745-750.

Licciardi, J.M., Kurz, M.D., Clark, P.U., and Brook, E.J., 1999, Calibration of cosmogenic ${ }^{3} \mathrm{He}$ production rates from Holocene lava flows in Oregon, USA, and effects of the Earth's magnetic field: Earth and Planetary Science Letters, v. 172, p. 261-271.

Macdonald, R., Smith, R.L., and Thomas, J.E., 1992, Chemistry of the subalkalic silicic obsidians: U.S. Geological Survey Professional Paper 1523, 214 p.

MacLeod, N.S., Sherrod, D.R., Chitwood, L.A., and Jensen, R.A., 1995, Geologic map of Newberry volcano, Deschutes, Klamath, and Lake Counties, Oregon: U.S. Geological Survey Miscellaneous Investigations Series Map I-2455, scales 1:62,500 and 1:24,000, 23 p., available at http://pubs.usgs.gov/imap/2455/.

MacLeod, N.S., Walker, G.W., and McKee, E.H., 1975, Geothermal significance of eastward increase in age of Upper Cenozoic rhyolite domes in southeastern Oregon: U.S. Geological Survey Open-File Report 75-348, 22 p.

Marcott, S.A., Fountain, A.G., O’Connor, J.E., Sniffen, P.J., and Dethier, D.P., 2009, A latest Pleistocene and Holocene glacial history and paleoclimate reconstruction at Three Sisters and Broken Top Volcanoes, Oregon, USA: Quaternary Research, v. 71, p. 181-189.

McCaffrey, R., Qamar, A.I., King, R.W., Wells, R., Khazaradze, G., Williams, C.A., Stevens, C.W., Vollick, J.J., and Zwick, P.C., 2007, Fault locking, block rotation and crustal deformation in the Pacific Northwest: Geophysical Journal International, v. 169, p. 1,315-1,340.

McCrory, P.A., Blair, J.L., Oppenheimer, D.H., and Walter, S.R., 2004, Depth to the Juan de Fuca slab beneath the Cascadia subduction margin - A 3-D model for sorting earthquakes: U.S. Geological Survey Data Series 91, 13 p., CD-ROM, available at http://pubs.usgs.gov/ds/91/.

Mercer, C.N., and Johnston, A.D., 2008, Experimental studies of the $\mathrm{P}-\mathrm{T}-\mathrm{H}_{2} \mathrm{O}$ near-liquidus phase relations of basaltic andesite from North Sister volcano, High Oregon Cascades - Constraints on lower-crustal mineral assemblages: Contributions to Mineralogy and Petrology, v. 155, p. 571-592.

Michaelson, C.A., and Weaver, C.S., 1986, Upper mantle structure from teleseismic $\mathrm{P}$ wave arrivals in Washington and northern Oregon: Journal of Geophysical Research, v. 91, p. 2,077-2,094.

Miller, R.B., 1989, The Mesozoic Rimrock Lake inlier, southern Washington Cascades-Implications for the basement to the Columbia Embayment: Geological Society of America Bulletin, v. 101, p. 1,289-1,305.
Mimura, K., 1984, Imbrication, flow direction and possible source areas of the pumice-flow tuffs near Bend, Oregon, U.S.A.: Journal of Volcanology and Geothermal Research, v. 21 , p. $45-60$.

Mimura, K., 1992, Reconnaissance geologic map of the west half of the Bend and east half of the Shevlin Park 7-1/2' quadrangles, Deschutes County, Oregon: U.S. Geological Survey Miscellaneous Field Studies Map MF-2189, scale $1: 24,000$.

Miyashiro, A., 1974, Volcanic rock series in island arcs and active continental margins: American Journal of Science, v. 274, p. 321-355.

Mooney, W.D., and Weaver, C.S., 1989, Regional crustal structure and tectonics of the Pacific coastal states, California, Oregon, and Washington: Geological Society of America Memoir 172, p. 129-161.

O'Connor, J.E., Hardison, J.H., and Costa, J.E., 2001, Debris flows from failures of Neoglacial-age dams in the Three Sisters and Mount Jefferson wilderness areas, Oregon: U.S. Geological Survey Professional Paper 1606, 93 p.

Peacock, M.A., 1931, Classification of igneous rock series: Journal of Geology, v. 39, p. 54-67.

Peck, D.L., 1964, Geologic reconnaissance of the AntelopeAshwood area, north-central Oregon: U.S. Geological Survey Bulletin 1161-D, 26 p.

Peck, D.L., Griggs, A.B., Schlicker, H.G., Wells, F.G., and Dole, H.M., 1964, Geology of the central and northern parts of the western Cascade Range in Oregon: U.S. Geological Survey Professional Paper 449, 56 p.

Pezzopane, S.K., and Weldon, R.J., 1993, Tectonic role of active faulting in central Oregon: Tectonics, v. 12, p. $1,140-1,169$.

Rasmussen, J., and Humphreys, E., 1988, Tomographic image of the Juan de Fuca plate beneath Washington and western Oregon using teleseismic P-wave travel times: Geophysical Research Letters, v. 15, p. 1,417-1,420.

Robinson, P.T., Brem, G.F., and McKee, E.H., 1984, John Day Formation of Oregon-A distal record of early Cascade volcanism: Geology, v. 12, p. 229-232.

Sarna-Wojcicki, A.M., Meyer, C.E., Nakata, J.K., Scott, W.E., Hill, B.E., Slate, J.L., and Russell, P.C., 1989, Age and correlation of mid-Quaternary ash beds and tuffs in the vicinity of Bend, Oregon: U.S. Geological Survey OpenFile Report 89-645, p. 55-66.

Schick, J.D., 1994, Origin of compositional variability of the lavas at Collier Cone, High Cascades, Oregon: Eugene, University of Oregon, M.S. thesis, $142 \mathrm{p}$.

Schmidt, M.E., 2005, Deep crustal and mantle inputs to North Sister volcano, Oregon High Cascade Range: Corvallis, Oregon State University, Ph.D. dissertation, 185 p.

Schmidt, M.E., and Grunder, A.L., 2009, The evolution of North Sister-A volcano shaped by extension and ice in the central Oregon Cascade Arc: Geological Society of America Bulletin, v. 121, p. 643-662.

Scott, W.E., 1977, Quaternary glaciation and volcanism, Metolius River area, Oregon: Geological Society of America Bulletin, v. 88, p. 113-124. 
Scott, W.E., 1987, Holocene rhyodacite eruptions on the flanks of South Sister volcano, Oregon, in Fink, J.H., ed., The emplacement of silicic domes and lava flows: Geological Society of America Special Paper 212, p. 35-53.

Scott, W.E., and Gardner, C.A., 1992, Geologic map of the Mount Bachelor volcanic chain and surrounding area, Cascade Range, Oregon: U.S. Geological Survey Miscellaneous Investigations Series Map I-1967, scale 1:50,000.

Scott, W.E., Gardner, C.A., and Sarna-Wojcicki, A.M., 1989, Guidebook for field trip to the Mount Bachelor-South Sister-Bend area, central Oregon High Cascades: U.S. Geological Survey Open-File Report 89-645, 66 p.

Scott, W.E., Iverson, R.M., Schilling, S.P., and Fisher, B.J., 2001, Volcano hazards in the Three Sisters region, Oregon: U.S. Geological Survey Open-File Report 99-437, 14 p., available at http://geopubs.wr.usgs.gov/ open-file/of99-437/.

Sherrod, D.R., and Smith, J.G., 2000, Geologic map of Upper Eocene to Holocene volcanic and related rocks of the Cascade Range, Oregon: U.S. Geological Survey Geologic Investigations Series Map I-2569, scale 1:500,000, pamphlet 17 p., available at http://pubs.usgs. gov/imap/i-2569/.

Sherrod, D.R., Taylor, E.M., Ferns, M.L., Scott, W.E., Conrey, R.M., and Smith, G.A., 2004, Geologic map of the Bend 30- x 60-minute quadrangle, central Oregon: U.S. Geological Survey Geologic Investigations Series Map I-2683, scale 1:100,000, pamphlet 48 p., available at http://pubs.usgs.gov/imap/i2683/.

Smith, D.R., and Leeman, W.P. 1987, Petrogenesis of Mount St. Helens dacitic magmas: Journal of Geophysical Research, v. 92 , p. $10,313-10,334$.

Smith, D.R., and Leeman, W.P., 1993, The origin of Mount St. Helens andesites: Journal of Volcanology and Geothermal Research, v. 55, p. 271-303.

Smith, G.A., 1987, The influence of explosive volcanism on fluvial sedimentation-The Deschutes Formation (Neogene) in central Oregon: Journal of Sedimentary Petrology, v. 57, p. 613-629.

Smith, G.A., Manchester, S.R., Ashwill, M., McIntosh, W.C., and Conrey, R.M., 1998, Late Eocene-early Oligocene tectonism, volcanism, and floristic change near Gray Butte, central Oregon: Geological Society of America Bulletin, v. 110, p. 759-778.

Smith, G.A., Snee, L.W., and Taylor, E.M., 1987, Stratigraphic, sedimentologic, and petrologic record of late Miocene subsidence of the central Oregon High Cascades: Geology, v. 15 , p. 389-392.

Smith, G.A., and Taylor, E.M., 1983, The central Oregon High Cascade graben-What? Where? When?: Geothermal Resources Council Transactions, v. 7, p. 275-279.

Spence, W., 1989, Stress origins and earthquake potentials in Cascadia: Journal of Geophysical Research, v. 94, p. 3,076-3,088.

Taggart, J.E., Jr., Lindsay, J.R., Scott, B.A., Vivit, D.V., Bartel, A.J., and Stewart, K.C., 1987, Analysis of geologic materials by wavelength-dispersive $\mathrm{x}$-ray fluorescence spectrometry, in Baedecker, P.A., ed., Methods for geochemical analysis: U.S. Geological Survey Bulletin 1770, p. E1-E19.

Taylor, E.M., 1965, Recent volcanism between Three Fingered Jack and North Sister, Oregon Cascade Range, Part I-History of volcanic activity: The Ore Bin, v. 27, no. 7, p. 121-147.

Taylor, E.M., 1968, Roadside geology, Santiam and McKenzie Pass Highways, Oregon, in Dole, H.M., ed., Andesite Conference Guidebook: Oregon Department of Geology and Mineral Industries Bulletin 62, p. 3-33.

Taylor, E.M., 1978, Field geology of S.W. Broken Top quadrangle, Oregon: Oregon Department of Geology and Mineral Industries Special Paper 2, $50 \mathrm{p}$.

Taylor, E.M., 1981, Central High Cascade roadside geology, in Johnston, D.A., and Donnelly-Nolan, J.M., eds., Guides to some volcanic terranes in Washington, Idaho, Oregon, and northern California: U.S. Geological Survey Circular 838, p. $55-83$.

Taylor, E.M., 1987, Field geology of the northwest quarter of the Broken Top 15' quadrangle, Deschutes County, Oregon: Oregon Department of Geology and Mineral Industries Special Paper 21, 20 p.

Taylor, E.M., 1990, Volcanic history and tectonic development of the central High Cascade Range, Oregon: Journal of Geophysical Research, v. 95, p. 19,611-19,622.

Taylor, E.M., and Ferns, M.L., 1994, Geology and mineral resources map of the Tumalo Dam quadrangle, Deschutes County, Oregon: Oregon Department of Geology and Mineral Industries, Geologic Map Series GMS-87, scale 1:24,000, pamphlet $4 \mathrm{p}$.

Taylor, E.M., and Ferns, M.L., 1995, Geologic map of the Three Creek Butte quadrangle, Deschutes County, Oregon: Oregon Department of Geology and Mineral Industries, Geologic Map Series GMS-81, scale 1:24,000, pamphlet 8 p.

Taylor, E.M., MacLeod, N.S., Sherrod, D.R., and Walker, G.W., 1987, Geologic map of the Three Sisters Wilderness, Deschutes, Lane, and Linn Counties, Oregon: U.S. Geological Survey Miscellaneous Field Studies Map MF-1952, scale 1:63,360.

Walcott, D., 1993, Neogene tectonics and kinematics of western North America: Tectonics, v. 12, p. 326-333.

Walker, G.W., and MacLeod, N.S., 1991, Geologic Map of Oregon: U.S. Geological Survey, scale 1:500,000, 2 sheets.

Walker, M., Johnsen, S., Rasmussen, S.O., Popp, T., Steffensen, J.-P., Gibbard, P., Hoek, W., Andrews, J., Björck, S., Cwynar, L.C., Hughen, K., Kershaw, P., Kromer, B., Litt, T., Lowe, D.J., Nakagawa, T., Newnham, R., and Schwander, J., 2009, Formal definition and dating of the GSSP (Global Stratotype Section and Point) for the base of the Holocene using the Greenland NGRIP ice core and selected auxiliary records: Journal of Quaternary Science, v. 24, p. 3-17.

Webster, J.R., 1992, Petrology of Quaternary volcanics of the Broken Top and Diamond Peak areas, central and southcentral Oregon High Cascades_Evidence for varied 
magmatic processes from two contrasting volcanic centers: Bloomington, Indiana University, Ph.D. dissertation, 412 p.

Wells, R.E., 1990, Paleomagnetic rotations and the Cenozoic tectonics of the Cascade arc, Washington, Oregon, and California: Journal of Geophysical Research, v. 95, p. 19,409-19,417.

Wells, R.E., and Heller, P.L., 1988, The relative contribution of accretion, shear, and extension to Cenozoic tectonic rotation in the Pacific Northwest: Geological Society of America Bulletin, v. 100, p. 325-338.

Wells, R.E., Weaver, C.S., and Blakely, R.J., 1998, Fore-arc migration in Cascadia and its neotectonic significance: Geology, v. 26, p. 759-762.

Wicks, C.W., Jr., Dzurisin, D., Ingebritsen, S., Thatcher, W., Lu, Z., and Iverson, J., 2002, Magmatic activity beneath the quiescent Three Sisters volcanic center, central Oregon Cascade Range, USA: Geophysical Research Letters, v. 29 (7), p. 26-1 to 26-4.

Williams, H., 1944, Volcanoes of the Three Sisters region, Oregon Cascades: University of California Publications, Bulletin of the Department of Geological Sciences, v. 27, no. 3, p. 37-84.

Williams, H., 1957, A geologic map of the Bend quadrangle, Oregon, and a reconnaissance geologic map of the central portion of the High Cascade Mountains: Oregon Department of Geology and Mineral Industries, scales $1: 125,000$ and $1: 250,000$.

Wozniak, K.C., 1982, Geology of the northern part of the Southeast Three Sisters quadrangle, Oregon: Corvallis, Oregon State University, M.S. thesis, 98 p.

Zoback, M.L., 1992, First- and second-order patterns of stress in the lithosphere-The World Stress Map Project: Journal of Geophysical Research, v. 97, p. 11,703-11,728. 
Table 1. Chemical data for Three Sisters volcanic cluster.

[Data are listed numerically by sample number within map units, which are listed alphabetically by unit label: initial letter a indicates andesite; $b$, basalt; $d$, dacite; $\mathrm{m}$, (mafic) basaltic andesite; $r$, rhyolite or rhyodacite. Volcanic group refers to groupings of volcanic rocks in Correlation of Map Units and in List of Map Units: BT, Broken Top and vicinity; MS, Middle Sister and vicinity; NS, North Sister and vicinity; P, peripheral centers and other lavas; s of BT, surficial deposits of Broken Top; SS, South Sister and vicinity. Other abbreviations: LOI, weight loss on ignition at $900^{\circ} \mathrm{C}$; na, not analyzed. Whole-rock major-element analyses are given in weight percent; trace elements, in ppm. Major elements normalized to volatile-free total of $99.6 \%$ (leaving $0.4 \%$ for trace oxides and halogens). Original total is volatile-free weight before normalization. $\mathrm{FeO} *$ is total $\mathrm{Fe}$ calculated as $\mathrm{FeO}$. Determinations by $\mathrm{x}$-ray fluorescence spectrometry at U.S. Geological Survey laboratory in Lakewood, Colo., supervised by J.E. Taggart (Taggart and others, 1987), or at GeoAnalytical Lab, Washington State University, Pullman, Wash., supervised by J.A. Wolff (www.sees.wsu.edu/Geolab/note/xrf.html)]

\begin{tabular}{|c|c|c|c|c|c|c|c|c|c|c|c|c|c|c|}
\hline Sample & $\begin{array}{l}\text { Unit } \\
\text { label }\end{array}$ & $\begin{array}{c}\text { Volcanic } \\
\text { group }\end{array}$ & $\mathrm{SiO}_{2}$ & $\mathrm{TiO}_{2}$ & $\mathrm{Al}_{2} \mathrm{O}_{3}$ & $\mathrm{Fe}$ 0* & MnO & MgO & $\mathrm{CaO}$ & $\mathrm{Na}_{2} \mathrm{O}$ & $\mathrm{K}_{2} \mathbf{O}$ & $\mathbf{P}_{2} \mathbf{O}_{5}$ & LOI & $\begin{array}{c}\text { Original } \\
\text { total }\end{array}$ \\
\hline \multicolumn{15}{|c|}{ Andesite and dacite of Broken Top } \\
\hline TS-324 & abt & $\mathrm{BT}$ & 63.60 & 1.20 & 15.57 & 6.03 & 0.13 & 1.61 & 3.87 & 5.38 & 1.84 & 0.38 & 0.02 & 99.13 \\
\hline TS-325 & $a b t$ & BT & 59.91 & 1.22 & 16.96 & 6.67 & 0.13 & 2.42 & 5.86 & 4.70 & 1.39 & 0.33 & $<0.01$ & 99.25 \\
\hline TS-326 & $a b t$ & BT & 64.95 & 0.99 & 15.58 & 5.26 & 0.11 & 1.46 & 3.68 & 4.87 & 2.35 & 0.35 & 0.21 & 99.06 \\
\hline TS-331 & $a b t$ & BT & 59.52 & 1.26 & 16.74 & 6.99 & 0.14 & 2.71 & 5.95 & 4.61 & 1.35 & 0.33 & 0.02 & 99.39 \\
\hline TS-332 & $a b t$ & BT & 59.95 & 1.21 & 16.81 & 6.72 & 0.13 & 2.54 & 5.84 & 4.68 & 1.38 & 0.33 & $<0.01$ & 99.52 \\
\hline TS-335 & $a b t$ & $\mathrm{BT}$ & 63.03 & 1.24 & 15.78 & 5.94 & 0.14 & 1.73 & 4.15 & 5.40 & 1.81 & 0.39 & na & 99.17 \\
\hline TS-343 & $a b t$ & $\mathrm{BT}$ & 68.64 & 0.63 & 15.29 & 3.67 & 0.11 & 0.69 & 2.18 & 5.95 & 2.23 & 0.22 & 0.04 & 99.69 \\
\hline TS-344 & $a b t$ & $\mathrm{BT}$ & 63.58 & 1.21 & 15.62 & 6.01 & 0.13 & 1.60 & 3.95 & 5.28 & 1.80 & 0.41 & 0.09 & 99.47 \\
\hline TS-716 & $a b t$ & $\mathrm{BT}$ & 63.62 & 1.20 & 15.88 & 5.79 & 0.14 & 1.51 & 3.78 & 5.45 & 1.90 & 0.34 & na & 99.41 \\
\hline \multicolumn{15}{|c|}{ Andesite of Pole Creek scoria cone } \\
\hline TS-250 & acp & $\mathrm{P}$ & 57.73 & 1.60 & 16.57 & 8.60 & 0.15 & 3.17 & 6.53 & 3.78 & 1.03 & 0.44 & -0.03 & 99.20 \\
\hline TS-614 & acp & $\mathrm{P}$ & 56.38 & 1.64 & 16.81 & 8.54 & 0.16 & 3.35 & 6.70 & 4.57 & 1.05 & 0.41 & na & 99.67 \\
\hline \multicolumn{15}{|c|}{ Andesite dome of Lewis Glacier headwall } \\
\hline TS-690 & adh & $\mathrm{SS}$ & 62.57 & 1.09 & 16.23 & 5.78 & 0.12 & 2.00 & 4.62 & 5.06 & 1.86 & 0.27 & na & 99.83 \\
\hline \multicolumn{15}{|c|}{ Andesite of Demaris Lake } \\
\hline TS-187 & adl & MS & 62.86 & 1.03 & 16.52 & 5.49 & 0.10 & 1.89 & 4.81 & 4.65 & 1.97 & 0.27 & 0.19 & 98.87 \\
\hline TS-447 & adl & MS & 61.07 & 1.16 & 16.99 & 6.27 & 0.11 & 2.16 & 5.40 & 4.36 & 1.75 & 0.33 & 0.09 & 99.65 \\
\hline TS-462 & adl & MS & 62.26 & 1.11 & 16.81 & 5.83 & 0.11 & 2.01 & 5.11 & 4.17 & 1.85 & 0.34 & 0.15 & 100.14 \\
\hline TS-562 & adl & MS & 61.30 & 1.16 & 16.94 & 6.05 & 0.11 & 2.09 & 5.32 & 4.52 & 1.85 & 0.27 & $<0.01$ & 98.79 \\
\hline TS-679 & adl & MS & 61.99 & 1.10 & 16.82 & 5.78 & 0.11 & 1.98 & 4.99 & 4.70 & 1.88 & 0.26 & na & 100.28 \\
\hline TS-681 & adl & MS & 61.95 & 1.09 & 16.77 & 5.72 & 0.11 & 1.97 & 5.14 & 4.72 & 1.87 & 0.26 & na & 99.68 \\
\hline \multicolumn{15}{|c|}{ Andesite tephra fall at base of east face of Middle Sister } \\
\hline TS-475A & aef & MS & 62.58 & 1.25 & 16.25 & 6.37 & 0.14 & 1.83 & 4.41 & 4.75 & 1.58 & 0.44 & 0.83 & 99.32 \\
\hline TS-475B & aef & MS & 62.66 & 1.25 & 16.22 & 6.36 & 0.14 & 1.78 & 4.41 & 4.77 & 1.57 & 0.43 & 0.94 & 98.87 \\
\hline TS-476A & aef & MS & 62.57 & 1.25 & 16.35 & 6.51 & 0.14 & 1.68 & 4.40 & 4.78 & 1.48 & 0.43 & 1.25 & 98.69 \\
\hline TS-476B & aef & MS & 63.07 & 1.26 & 16.40 & 6.07 & 0.13 & 1.55 & 4.31 & 4.64 & 1.73 & 0.44 & 1.76 & 98.38 \\
\hline \multicolumn{15}{|c|}{ Andesite of Eugene Glacier } \\
\hline TS-45A & aeg & SS & 60.28 & 1.21 & 17.24 & 6.23 & 0.11 & 2.63 & 5.93 & 4.38 & 1.30 & 0.29 & 0.41 & 98.80 \\
\hline TS-45B & aeg & SS & 56.61 & 1.16 & 17.45 & 8.74 & 0.11 & 3.49 & 6.71 & 4.08 & 0.93 & 0.33 & 1.31 & 98.18 \\
\hline TS-46 & aeg & SS & 58.24 & 1.17 & 17.18 & 7.07 & 0.13 & 3.45 & 6.30 & 4.44 & 1.31 & 0.32 & $<0.01$ & 99.70 \\
\hline TS-49 & aeg & SS & 60.43 & 1.11 & 16.66 & 6.83 & 0.11 & 2.65 & 5.38 & 4.45 & 1.70 & 0.28 & 0.85 & 99.22 \\
\hline TS-195 & aeg & SS & 57.09 & 1.24 & 17.36 & 7.59 & 0.13 & 3.68 & 6.77 & 4.30 & 1.13 & 0.29 & -0.09 & 99.26 \\
\hline TS-196 & aeg & SS & 57.16 & 1.24 & 17.38 & 7.58 & 0.13 & 3.64 & 6.77 & 4.28 & 1.15 & 0.28 & -0.05 & 99.15 \\
\hline TS-197 & aeg & SS & 56.55 & 1.25 & 17.38 & 7.70 & 0.13 & 3.96 & 7.11 & 4.19 & 1.05 & 0.29 & 0.03 & 99.17 \\
\hline TS-198 & aeg & SS & 57.41 & 1.24 & 17.12 & 7.53 & 0.13 & 3.66 & 6.75 & 4.29 & 1.19 & 0.28 & 0.27 & 98.89 \\
\hline TS-200 & aeg & SS & 57.56 & 1.27 & 17.18 & 7.54 & 0.13 & 3.44 & 6.70 & 4.32 & 1.19 & 0.29 & 0.16 & 99.16 \\
\hline TS-202 & aeg & SS & 56.52 & 1.25 & 17.46 & 7.77 & 0.13 & 3.86 & 7.10 & 4.18 & 1.05 & 0.29 & -0.05 & 98.68 \\
\hline TS-203 & aeg & SS & 57.54 & 1.26 & 17.09 & 7.59 & 0.13 & 3.51 & 6.67 & 4.31 & 1.19 & 0.29 & 0.40 & 98.49 \\
\hline TS-229 & aeg & SS & 56.73 & 1.26 & 17.45 & 7.74 & 0.13 & 3.79 & 6.94 & 4.22 & 1.07 & 0.29 & -0.21 & 99.90 \\
\hline TS-230 & aeg & SS & 56.49 & 1.27 & 17.47 & 7.76 & 0.14 & 3.90 & 7.02 & 4.21 & 1.05 & 0.30 & -0.17 & 99.80 \\
\hline TS-232 & aeg & SS & 56.39 & 1.32 & 17.10 & 8.85 & 0.14 & 3.35 & 6.88 & 4.30 & 1.00 & 0.28 & -0.19 & 99.62 \\
\hline TS-259 & aeg & SS & 56.65 & 1.25 & 17.48 & 7.64 & 0.13 & 3.87 & 7.03 & 4.20 & 1.08 & 0.28 & 0.28 & 99.16 \\
\hline
\end{tabular}




\begin{tabular}{|c|c|c|c|c|c|c|c|c|c|c|c|c|c|c|}
\hline $\mathrm{Ba}$ & Ce & $\mathrm{Cr}$ & $\mathrm{Cu}$ & Ga & La & $\mathbf{N b}$ & Nd & $\mathrm{Ni}$ & $\mathbf{R b}$ & $\mathrm{Sr}$ & $\mathbf{V}$ & $\mathbf{Y}$ & Zn & $\mathrm{Zr}$ \\
\hline \multicolumn{15}{|c|}{ Andesite and dacite of Broken Top } \\
\hline 564 & 41 & na & 23 & 25 & 18 & 14 & 24 & na & 38 & 355 & 114 & 50 & 82 & 276 \\
\hline 468 & 34 & 6 & 41 & 15 & 8 & 8 & 15 & 3 & 26 & 427 & 139 & 27 & 72 & 170 \\
\hline 750 & 55 & $<5$ & 14 & 16 & 33 & 13 & 47 & 3 & 53 & 292 & 76 & 40 & 55 & 293 \\
\hline 457 & 34 & 6 & 37 & 16 & 11 & 8 & 13 & 3 & 24 & 423 & 152 & 26 & 71 & 170 \\
\hline 465 & 33 & $<5$ & 34 & 17 & 10 & 8 & $<10$ & 3 & 26 & 426 & 137 & 27 & 64 & 171 \\
\hline 525 & 42 & 0 & 19 & 20 & 20 & 10 & 26 & 0 & 34 & 366 & 79 & 37 & 90 & 202 \\
\hline 712 & 49 & $<5$ & $<2$ & 16 & 22 & 10 & 30 & 3 & 39 & 241 & 8 & 39 & 62 & 257 \\
\hline 581 & 41 & $<5$ & 19 & 15 & 18 & 11 & 43 & 3 & 36 & 347 & 80 & 39 & 78 & 222 \\
\hline 545 & 40 & 1 & 30 & 19 & 20 & 11 & 26 & 0 & 38 & 330 & 76 & 37 & 88 & 219 \\
\hline \multicolumn{15}{|c|}{ Andesite of Pole Creek scoria cone } \\
\hline 334 & 26 & 6 & 33 & 20 & 12 & 7 & 13 & 14 & 17 & 517 & 216 & 28 & 93 & 128 \\
\hline 358 & 29 & 7 & 67 & 21 & 11 & 5 & 20 & 3 & 16 & 531 & 226 & 27 & 88 & 125 \\
\hline \multicolumn{15}{|c|}{ Andesite dome of Lewis Glacier headwall } \\
\hline 552 & 38 & 7 & 39 & 19 & 19 & 8 & 22 & 1 & 33 & 403 & 123 & 27 & 78 & 197 \\
\hline \multicolumn{15}{|c|}{ Andesite of Demaris Lake } \\
\hline 588 & 33 & 9 & 26 & 20 & 19 & 12 & 26 & 10 & 41 & 388 & 107 & 27 & 69 & 212 \\
\hline 570 & 36 & $<5$ & 25 & 16 & 13 & 8 & 30 & 3 & 32 & 421 & 142 & 22 & 68 & 195 \\
\hline 605 & 38 & $<5$ & 23 & 15 & 17 & 8 & $<10$ & 3 & 36 & 406 & 127 & 22 & 63 & 202 \\
\hline 597 & 34 & $<5$ & 25 & 16 & 14 & 8 & 20 & 8 & 32 & 420 & 127 & 23 & 58 & 193 \\
\hline 568 & 38 & 12 & 26 & 18 & 19 & 8 & 22 & 7 & 35 & 400 & 125 & 25 & 73 & 196 \\
\hline 552 & 33 & 12 & 30 & 19 & 17 & 9 & 17 & 8 & 36 & 406 & 130 & 25 & 69 & 191 \\
\hline \multicolumn{15}{|c|}{ Andesite tephra fall at base of east face of Middle Sister } \\
\hline 627 & 45 & $<5$ & 12 & 16 & 15 & 8 & 42 & 3 & 25 & 415 & 93 & 29 & 105 & 211 \\
\hline 637 & 43 & $<5$ & 22 & 16 & 13 & 9 & 29 & 3 & 25 & 419 & 90 & 30 & 116 & 212 \\
\hline 646 & 42 & $<5$ & 2 & 16 & 18 & 8 & 29 & 3 & 27 & 418 & 84 & 29 & 79 & 212 \\
\hline 620 & 40 & 39 & 4 & 17 & 13 & 9 & 35 & 3 & 27 & 415 & 102 & 31 & 89 & 213 \\
\hline \multicolumn{15}{|c|}{ Andesite of Eugene Glacier } \\
\hline 456 & 29 & 25 & 25 & 21 & 12 & 9 & 11 & 9 & 22 & 469 & 144 & 23 & 68 & 173 \\
\hline 370 & 26 & 60 & 28 & 22 & 12 & 7 & 17 & 34 & 15 & 478 & 159 & 23 & 65 & 151 \\
\hline 417 & 27 & 34 & 42 & 21 & 14 & 8 & 17 & 18 & 21 & 466 & 151 & 23 & 79 & 168 \\
\hline 511 & 30 & 13 & 37 & 22 & 16 & 8 & 8 & 17 & 31 & 423 & 144 & 29 & 72 & 180 \\
\hline 378 & 23 & 38 & 57 & 21 & 11 & 8 & $<10$ & 23 & 18 & 497 & 168 & 24 & 79 & 154 \\
\hline 381 & 24 & 33 & 66 & 21 & 10 & 7 & $<10$ & 24 & 19 & 500 & 175 & 23 & 77 & 153 \\
\hline 361 & 30 & 46 & 65 & 20 & 12 & 7 & 16 & 24 & 16 & 506 & 174 & 22 & 80 & 147 \\
\hline 383 & 27 & 36 & 54 & 20 & 13 & 8 & 17 & 22 & 20 & 487 & 170 & 23 & 78 & 156 \\
\hline 390 & 29 & 31 & 61 & 20 & 15 & 8 & $<10$ & 21 & 21 & 485 & 183 & 24 & 83 & 156 \\
\hline 353 & 29 & 39 & 50 & 19 & 12 & 7 & 15 & 26 & 16 & 513 & 168 & 23 & 76 & 146 \\
\hline 387 & 28 & 27 & 68 & 20 & 12 & 8 & 22 & 18 & 21 & 487 & 177 & 24 & 84 & 155 \\
\hline 367 & 30 & 37 & 64 & 19 & 15 & 7 & 17 & 24 & 17 & 510 & 174 & 23 & 85 & 151 \\
\hline 362 & 29 & 41 & 75 & 20 & 14 & 7 & 12 & 25 & 16 & 513 & 171 & 22 & 85 & 145 \\
\hline 381 & 30 & 9 & 94 & 19 & 14 & 8 & 17 & 16 & 16 & 556 & 234 & 23 & 87 & 134 \\
\hline 370 & 27 & 47 & 68 & 22 & 11 & 9 & 16 & 30 & 18 & 505 & 172 & 24 & 81 & 153 \\
\hline
\end{tabular}


Table 1. Chemical data for Three Sisters volcanic cluster.-Continued

\begin{tabular}{|c|c|c|c|c|c|c|c|c|c|c|c|c|c|c|}
\hline Sample & $\begin{array}{l}\text { Unit } \\
\text { label }\end{array}$ & $\begin{array}{c}\text { Volcanic } \\
\text { group }\end{array}$ & $\mathrm{SiO}_{2}$ & $\mathrm{TiO}_{2}$ & $\mathrm{Al}_{2} \mathrm{O}_{3}$ & $\mathrm{FeO*}$ & $\mathrm{MnO}$ & MgO & $\mathrm{CaO}$ & $\mathrm{Na}_{2} \mathrm{O}$ & $\mathrm{K}_{2} \mathrm{O}$ & $\mathrm{P}_{2} \mathbf{O}_{5}$ & LOI & $\begin{array}{c}\text { Original } \\
\text { total }\end{array}$ \\
\hline \multicolumn{15}{|c|}{ Andesite of Eugene Glacier-Continued } \\
\hline TS-274 & aeg & SS & 59.81 & 1.21 & 16.69 & 6.87 & 0.12 & 2.84 & 5.77 & 4.53 & 1.48 & 0.29 & 0.13 & 99.09 \\
\hline TS-275 & aeg & SS & 58.12 & 1.26 & 16.97 & 7.42 & 0.13 & 3.33 & 6.37 & 4.44 & 1.26 & 0.29 & 0.08 & 99.22 \\
\hline TS-276 & aeg & SS & 58.27 & 1.27 & 16.94 & 7.40 & 0.13 & 3.23 & 6.34 & 4.46 & 1.28 & 0.29 & 0.09 & 98.80 \\
\hline TS-277 & aeg & SS & 58.27 & 1.26 & 16.91 & 7.39 & 0.13 & 3.26 & 6.41 & 4.41 & 1.27 & 0.29 & -0.23 & 98.96 \\
\hline TS-278 & aeg & SS & 57.29 & 1.25 & 17.25 & 7.63 & 0.13 & 3.58 & 6.77 & 4.29 & 1.14 & 0.28 & -0.07 & 98.75 \\
\hline TS-279 & aeg & $\mathrm{SS}$ & 56.84 & 1.24 & 17.34 & 7.62 & 0.13 & 3.84 & 6.97 & 4.23 & 1.10 & 0.28 & 0.04 & 99.35 \\
\hline TS-485 & aeg & $\mathrm{SS}$ & 57.55 & 1.18 & 17.45 & 7.31 & 0.13 & 3.86 & 6.80 & 3.84 & 1.16 & 0.32 & $<0.01$ & 99.86 \\
\hline TS-513 & aeg & $\mathrm{SS}$ & 57.44 & 1.22 & 17.20 & 7.59 & 0.13 & 3.70 & 6.87 & 4.00 & 1.13 & 0.32 & $<0.01$ & 99.02 \\
\hline TS-546 & aeg & SS & 56.33 & 1.28 & 17.53 & 7.78 & 0.14 & 4.00 & 7.08 & 4.16 & 1.03 & 0.26 & $<0.01$ & 98.84 \\
\hline TS-547 & aeg & SS & 56.04 & 1.32 & 17.61 & 7.85 & 0.15 & 3.96 & 7.10 & 4.28 & 1.02 & 0.26 & $<0.01$ & 99.53 \\
\hline TS-573 & aeg & SS & 56.39 & 1.29 & 17.59 & 7.75 & 0.13 & 3.88 & 7.00 & 4.25 & 1.06 & 0.26 & $<0.01$ & 99.08 \\
\hline TS-577 & aeg & SS & 59.15 & 1.19 & 16.83 & 6.99 & 0.13 & 3.07 & 6.01 & 4.49 & 1.40 & 0.34 & $<0.01$ & 100.03 \\
\hline TS-585 & aeg & SS & 57.07 & 1.17 & 17.48 & 7.33 & 0.13 & 3.89 & 6.85 & 4.21 & 1.14 & 0.33 & 0.36 & 99.13 \\
\hline TS-586 & aeg & $\mathrm{SS}$ & 56.21 & 1.19 & 17.73 & 7.58 & 0.13 & 4.15 & 7.28 & 4.02 & 0.99 & 0.31 & 0.31 & 99.40 \\
\hline TS-583 & aeg & SS & 57.03 & 1.17 & 17.44 & 7.35 & 0.13 & 3.89 & 6.87 & 4.23 & 1.15 & 0.34 & 0.17 & 99.37 \\
\hline TS-584 & aeg & SS & 56.69 & 1.18 & 17.50 & 7.43 & 0.13 & 4.06 & 7.02 & 4.18 & 1.07 & 0.33 & $<0.01$ & 100.14 \\
\hline TS-721 & aeg & SS & 57.11 & 1.25 & 17.42 & 7.38 & 0.13 & 3.68 & 6.82 & 4.40 & 1.15 & 0.27 & na & 99.60 \\
\hline \multicolumn{15}{|c|}{ Andesite tephra fall of Hodge Crest } \\
\hline TS-713A & ahc & $\mathrm{SS}$ & 61.85 & 1.18 & 16.39 & 6.05 & 0.12 & 2.06 & 4.89 & 4.98 & 1.79 & 0.28 & na & 99.18 \\
\hline TS-713D & ahc & SS & 61.68 & 1.20 & 16.31 & 6.06 & 0.13 & 2.20 & 4.95 & 4.70 & 2.09 & 0.28 & na & 98.57 \\
\hline TS-713E & ahc & SS & 61.65 & 1.19 & 16.40 & 6.08 & 0.12 & 2.25 & 5.06 & 4.67 & 1.90 & 0.28 & na & 98.77 \\
\hline \multicolumn{15}{|c|}{ Andesite intrusive complex of Hodge Crest } \\
\hline TS-44 & ahi & $\mathrm{SS}$ & 60.52 & 1.19 & 16.64 & 6.76 & 0.11 & 2.42 & 5.35 & 4.65 & 1.62 & 0.33 & 0.82 & 98.74 \\
\hline TS-689 & ahi & SS & 56.56 & 1.19 & 17.62 & 7.24 & 0.13 & 4.03 & 7.24 & 4.24 & 1.10 & 0.25 & na & 99.24 \\
\hline TS-714 & ahi & $\mathrm{SS}$ & 61.95 & 1.30 & 15.96 & 6.39 & 0.11 & 2.21 & 4.50 & 4.94 & 1.89 & 0.34 & na & 98.92 \\
\hline \multicolumn{15}{|c|}{ Andesite of headwaters of Linton Creek } \\
\hline TS-269 & ahl & MS & 57.92 & 1.33 & 16.85 & 8.20 & 0.14 & 2.90 & 6.12 & 4.60 & 1.22 & 0.31 & 0.37 & 98.71 \\
\hline TS-281 & ahl & MS & 57.76 & 1.33 & 16.98 & 8.25 & 0.15 & 2.90 & 6.11 & 4.64 & 1.17 & 0.31 & 0.03 & 99.14 \\
\hline TS-282 & ahl & MS & 57.73 & 1.33 & 16.96 & 8.25 & 0.14 & 2.90 & 6.16 & 4.63 & 1.18 & 0.32 & 0.39 & 98.69 \\
\hline TS-283 & ahl & MS & 57.86 & 1.32 & 16.85 & 8.25 & 0.14 & 2.88 & 6.11 & 4.68 & 1.18 & 0.32 & -0.24 & 99.32 \\
\hline TS-285 & ahl & MS & 57.14 & 1.33 & 17.01 & 8.49 & 0.14 & 3.08 & 6.42 & 4.56 & 1.12 & 0.30 & -0.26 & 99.53 \\
\hline \multicolumn{15}{|c|}{ Andesite of Linton Creek } \\
\hline TS-267 & alc & MS & 61.77 & 1.22 & 16.39 & 6.35 & 0.13 & 1.98 & 4.65 & 5.06 & 1.72 & 0.34 & 0.01 & 99.65 \\
\hline TS-284 & alc & MS & 61.60 & 1.21 & 16.56 & 6.37 & 0.13 & 2.00 & 4.63 & 5.08 & 1.69 & 0.33 & 0.64 & 98.63 \\
\hline TS-286 & alc & MS & 61.74 & 1.22 & 16.34 & 6.39 & 0.13 & 1.98 & 4.61 & 5.12 & 1.73 & 0.33 & -0.10 & 99.38 \\
\hline TS-293 & alc & MS & 61.84 & 1.23 & 16.19 & 6.39 & 0.13 & 1.99 & 4.67 & 5.05 & 1.78 & 0.32 & 0.84 & 98.41 \\
\hline TS-298A & alc & MS & 61.90 & 1.22 & 16.35 & 6.37 & 0.13 & 1.91 & 4.62 & 5.02 & 1.75 & 0.33 & 0.00 & 99.28 \\
\hline TS-298B & alc & MS & 61.86 & 1.22 & 16.29 & 6.39 & 0.13 & 2.01 & 4.64 & 4.99 & 1.75 & 0.32 & -0.03 & 99.02 \\
\hline TS-299 & alc & MS & 61.89 & 1.21 & 16.35 & 6.38 & 0.13 & 2.01 & 4.62 & 4.95 & 1.74 & 0.32 & -0.04 & 99.30 \\
\hline TS-300 & alc & MS & 62.16 & 1.20 & 16.34 & 6.28 & 0.13 & 1.89 & 4.50 & 4.98 & 1.78 & 0.32 & 0.06 & 99.35 \\
\hline TS-301 & alc & MS & 62.08 & 1.20 & 16.20 & 6.30 & 0.13 & 1.97 & 4.62 & 5.00 & 1.78 & 0.32 & 0.42 & 98.99 \\
\hline TS-548 & alc & MS & 61.73 & 1.26 & 16.31 & 6.42 & 0.13 & 2.03 & 4.70 & 4.95 & 1.78 & 0.29 & $<0.01$ & 99.55 \\
\hline TS-549 & alc & MS & 62.99 & 1.14 & 16.15 & 5.84 & 0.12 & 1.88 & 4.40 & 4.89 & 1.94 & 0.26 & 0.86 & 98.67 \\
\hline TS-557 & alc & MS & 61.88 & 1.24 & 16.43 & 6.34 & 0.14 & 1.99 & 4.67 & 4.89 & 1.74 & 0.29 & 0.05 & 98.83 \\
\hline \multicolumn{15}{|c|}{ Andesite west of Lost Creek Glacier } \\
\hline TS-256 & alg & SS & 62.20 & 1.17 & 16.40 & 6.06 & 0.12 & 2.01 & 4.62 & 4.84 & 1.85 & 0.33 & -0.03 & 99.60 \\
\hline TS-258 & alg & SS & 62.28 & 1.16 & 16.32 & 6.04 & 0.12 & 2.00 & 4.64 & 4.88 & 1.84 & 0.32 & -0.09 & 99.47 \\
\hline TS-260 & alg & SS & 61.67 & 1.18 & 16.36 & 6.25 & 0.12 & 2.18 & 4.91 & 4.86 & 1.76 & 0.32 & -0.18 & 99.82 \\
\hline TS-261 & alg & SS & 61.45 & 1.19 & 16.41 & 6.37 & 0.12 & 2.26 & 4.97 & 4.78 & 1.72 & 0.31 & -0.08 & 99.52 \\
\hline
\end{tabular}




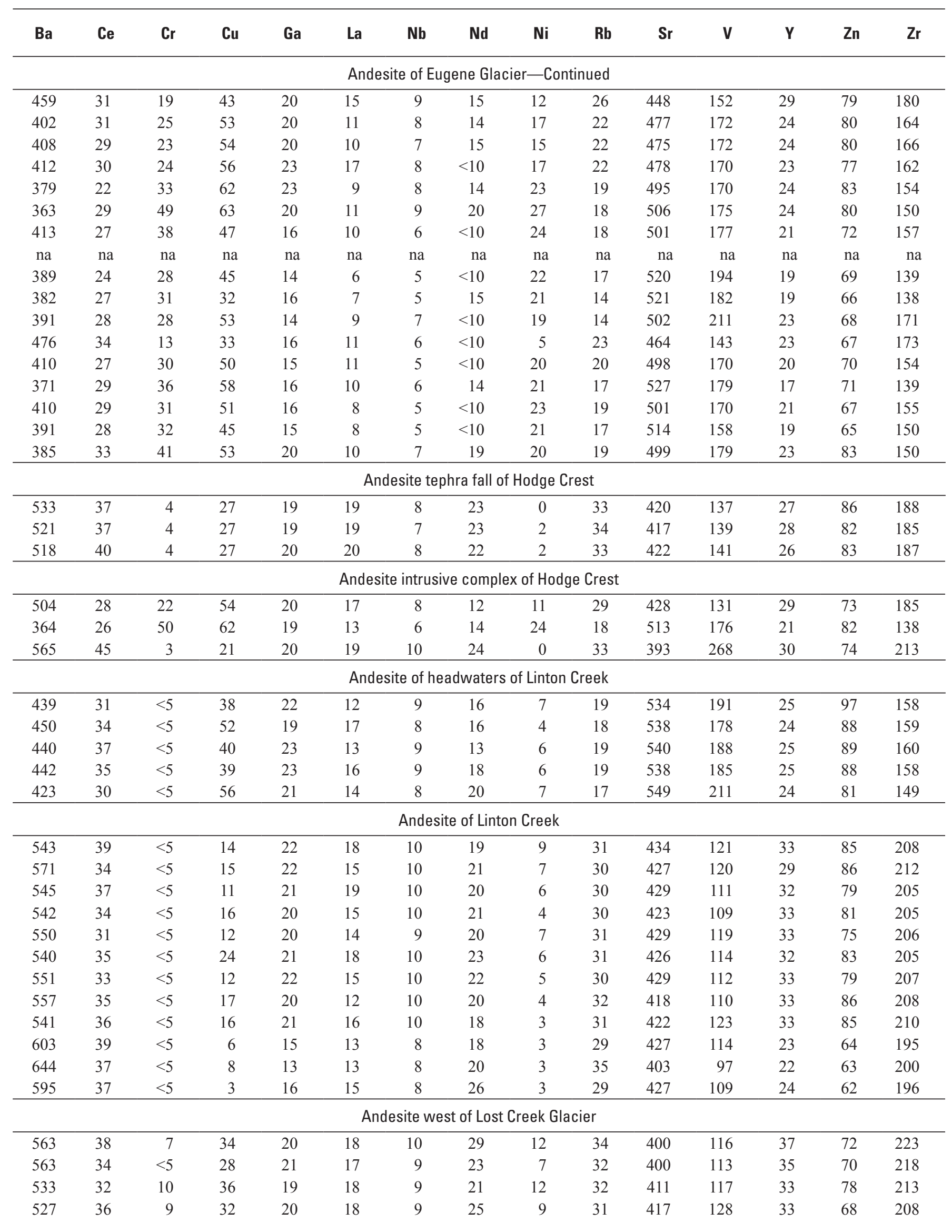


Table 1. Chemical data for Three Sisters volcanic cluster--Continued

\begin{tabular}{|c|c|c|c|c|c|c|c|c|c|c|c|c|c|c|}
\hline Sample & $\begin{array}{l}\text { Unit } \\
\text { label }\end{array}$ & $\begin{array}{c}\text { Volcanic } \\
\text { group }\end{array}$ & $\mathrm{SiO}_{2}$ & $\mathrm{TiO}_{2}$ & $\mathrm{Al}_{2} \mathrm{O}_{3}$ & $\mathrm{FeO}$ * & MnO & MgO & $\mathrm{CaO}$ & $\mathrm{Na}_{2} \mathrm{O}$ & $\mathrm{K}_{2} \mathrm{O}$ & $\mathrm{P}_{2} \mathrm{O}_{5}$ & LOI & $\begin{array}{c}\text { Original } \\
\text { total }\end{array}$ \\
\hline \multicolumn{15}{|c|}{ Andesite west of Lost Creek Glacier-Continued } \\
\hline TS-262 & alg & SS & 62.11 & 1.17 & 16.40 & 6.12 & 0.12 & 2.00 & 4.63 & 4.90 & 1.83 & 0.32 & -0.04 & 99.59 \\
\hline TS-263 & alg & SS & 62.16 & 1.16 & 16.39 & 6.05 & 0.12 & 2.04 & 4.66 & 4.87 & 1.84 & 0.32 & -0.10 & 99.66 \\
\hline TS-264 & alg & SS & 62.29 & 1.17 & 16.30 & 6.06 & 0.12 & 1.98 & 4.61 & 4.89 & 1.86 & 0.32 & -0.14 & 99.61 \\
\hline TS-265 & alg & SS & 62.05 & 1.15 & 16.44 & 6.10 & 0.12 & 2.05 & 4.68 & 4.86 & 1.82 & 0.32 & -0.06 & 99.36 \\
\hline TS-272 & alg & SS & 62.08 & 1.17 & 16.12 & 6.41 & 0.12 & 2.11 & 4.79 & 4.70 & 1.81 & 0.28 & 0.05 & 99.47 \\
\hline TS-312 & alg & SS & 62.25 & 1.16 & 16.37 & 6.03 & 0.11 & 1.96 & 4.61 & 4.94 & 1.86 & 0.31 & -0.10 & 99.20 \\
\hline TS-313 & alg & SS & 62.12 & 1.16 & 16.36 & 6.10 & 0.12 & 2.04 & 4.64 & 4.91 & 1.84 & 0.31 & -0.16 & 99.24 \\
\hline TS-314 & alg & SS & 62.11 & 1.17 & 16.23 & 6.14 & 0.12 & 2.04 & 4.71 & 4.94 & 1.82 & 0.32 & -0.06 & 99.43 \\
\hline TS-316 & alg & SS & 62.01 & 1.17 & 16.36 & 6.19 & 0.12 & 2.05 & 4.68 & 4.90 & 1.81 & 0.32 & -0.06 & 99.26 \\
\hline TS-317 & alg & SS & 62.07 & 1.17 & 16.42 & 6.10 & 0.12 & 1.99 & 4.65 & 4.94 & 1.83 & 0.32 & -0.09 & 99.49 \\
\hline TS-318 & alg & SS & 61.90 & 1.17 & 16.40 & 6.17 & 0.12 & 2.07 & 4.65 & 4.97 & 1.82 & 0.33 & -0.03 & 99.60 \\
\hline TS-319 & alg & SS & 62.19 & 1.17 & 16.32 & 6.07 & 0.12 & 2.02 & 4.55 & 4.99 & 1.84 & 0.32 & -0.04 & 99.45 \\
\hline TS-273 & alg & SS & 63.46 & 1.04 & 16.17 & 5.62 & 0.11 & 1.75 & 4.29 & 4.94 & 1.96 & 0.27 & 0.15 & 99.20 \\
\hline \multicolumn{15}{|c|}{ Andesite of Lewis Glacier headwall } \\
\hline TS-580 & alh & $\mathrm{SS}$ & 62.03 & 1.13 & 16.20 & 6.10 & 0.12 & 1.98 & 4.65 & 5.20 & 1.82 & 0.36 & 0.16 & 100.19 \\
\hline TS-687 & alh & SS & 62.93 & 1.10 & 16.17 & 5.79 & 0.11 & 1.87 & 4.44 & 4.99 & 1.93 & 0.27 & na & 99.80 \\
\hline TS-688 & alh & SS & 62.61 & 1.10 & 16.19 & 5.76 & 0.12 & 1.99 & 4.65 & 5.05 & 1.86 & 0.27 & na & 99.32 \\
\hline TS-688R & alh & SS & 62.58 & 1.10 & 16.17 & 5.81 & 0.12 & 2.00 & 4.64 & 5.05 & 1.86 & 0.27 & na & 99.57 \\
\hline
\end{tabular}

Andesite south of Lewis Glacier

\begin{tabular}{|c|c|c|c|c|c|c|c|c|c|c|c|c|c|c|}
\hline TS-479 & als & $\mathrm{SS}$ & 62.35 & 1.04 & 16.18 & 6.11 & 0.11 & 2.48 & 5.21 & 4.08 & 1.76 & 0.28 & $<0.01$ & 100.33 \\
\hline \multicolumn{15}{|c|}{ Andesite agglutinate north of Hayden Glacier } \\
\hline TS-182 & anh & NS & 57.86 & 1.42 & 16.85 & 8.11 & 0.14 & 2.86 & 6.04 & 4.73 & 1.23 & 0.36 & -0.24 & 99.32 \\
\hline TS-472 & anh & NS & 58.04 & 1.42 & 16.90 & 8.20 & 0.15 & 2.93 & 6.13 & 4.23 & 1.20 & 0.39 & $<0.01$ & 100.21 \\
\hline \multicolumn{15}{|c|}{ Andesite of Obsidian Creek } \\
\hline TS-104 & aoc & MS & 61.53 & 0.77 & 16.40 & 5.52 & 0.10 & 3.89 & 5.73 & 3.89 & 1.60 & 0.19 & 0.09 & 100.20 \\
\hline TS-294 & aoc & MS & 59.91 & 0.83 & 16.60 & 6.02 & 0.11 & 4.36 & 6.38 & 3.83 & 1.41 & 0.14 & 0.10 & 99.58 \\
\hline TS-295 & aoc & MS & 60.04 & 0.82 & 16.61 & 5.95 & 0.11 & 4.32 & 6.31 & 3.87 & 1.42 & 0.14 & 0.05 & 99.54 \\
\hline TS-296 & aoc & MS & 62.18 & 0.74 & 16.07 & 5.37 & 0.10 & 3.70 & 5.72 & 3.93 & 1.66 & 0.14 & 0.39 & 99.16 \\
\hline TS-386 & aoc & MS & 58.60 & 0.89 & 16.71 & 6.38 & 0.11 & 4.73 & 6.95 & 3.81 & 1.25 & 0.17 & $<0.01$ & 98.92 \\
\hline TS-426 & aoc & MS & 61.78 & 0.75 & 16.17 & 5.48 & 0.10 & 3.82 & 5.82 & 3.92 & 1.61 & 0.15 & 0.14 & 99.14 \\
\hline TS-427 & aoc & MS & 61.73 & 0.79 & 16.41 & 5.54 & 0.10 & 3.74 & 5.90 & 3.60 & 1.60 & 0.19 & 0.79 & 98.91 \\
\hline TS-553 & aoc & MS & 60.81 & 0.79 & 16.46 & 5.75 & 0.11 & 4.12 & 6.08 & 3.84 & 1.52 & 0.11 & 0.10 & 99.25 \\
\hline TS-559 & aoc & MS & 60.12 & 0.83 & 16.61 & 5.95 & 0.12 & 4.32 & 6.35 & 3.75 & 1.43 & 0.11 & $<0.01$ & 99.56 \\
\hline TS-560 & aoc & MS & 62.39 & 0.74 & 16.00 & 5.29 & 0.12 & 3.68 & 5.62 & 3.96 & 1.67 & 0.13 & 0.21 & 99.61 \\
\hline TS-610 & aoc & MS & 63.15 & 0.71 & 15.91 & 4.92 & 0.10 & 3.51 & 5.40 & 4.05 & 1.75 & 0.11 & na & 100.64 \\
\hline \multicolumn{15}{|c|}{ Andesite of Park Creek } \\
\hline TS-498 & apc & $\mathrm{SS}$ & 61.44 & 1.20 & 16.26 & 6.68 & 0.12 & 2.45 & 5.33 & 4.08 & 1.73 & 0.32 & 0.02 & 99.86 \\
\hline TS-621 & apc & SS & 60.96 & 1.20 & 16.20 & 6.57 & 0.12 & 2.49 & 5.39 & 4.67 & 1.74 & 0.27 & na & 97.43 \\
\hline TS-622 & apc & SS & 61.60 & 1.13 & 16.16 & 6.27 & 0.12 & 2.39 & 5.20 & 4.68 & 1.79 & 0.25 & na & 98.58 \\
\hline \multicolumn{15}{|c|}{ Andesite of Prouty Glacier headwall } \\
\hline TS-708 & aph & SS & 61.40 & 1.28 & 16.17 & 6.42 & 0.13 & 2.23 & 5.08 & 4.81 & 1.75 & 0.32 & na & 99.09 \\
\hline TS-712 & aph & SS & 61.61 & 1.28 & 16.11 & 6.31 & 0.09 & 2.31 & 4.90 & 4.82 & 1.84 & 0.32 & na & 98.26 \\
\hline \multicolumn{15}{|c|}{ Andesite tephra fall near base of Prouty Glacier headwall } \\
\hline TS-709 & aph' & SS & 59.29 & 1.31 & 16.66 & 7.05 & 0.13 & 2.81 & 6.05 & 4.62 & 1.39 & 0.29 & na & 98.52 \\
\hline TS-710 & $\begin{array}{l}\text { aph' } \\
\text { [lithic] }\end{array}$ & SS & 61.81 & 1.28 & 16.08 & 6.49 & 0.11 & 1.84 & 5.04 & 4.83 & 1.80 & 0.32 & na & 98.83 \\
\hline TS-711 & aph' & $\mathrm{SS}$ & 63.74 & 1.10 & 15.95 & 5.50 & 0.12 & 1.66 & 4.21 & 5.12 & 1.89 & 0.30 & na & 99.10 \\
\hline
\end{tabular}




\begin{tabular}{|c|c|c|c|c|c|c|c|c|c|c|c|c|c|c|}
\hline $\mathbf{B a}$ & Ce & Cr & $\mathrm{Cu}$ & $\mathbf{G a}$ & La & Nb & Nd & $\mathbf{N i}$ & $\mathbf{R b}$ & $\mathrm{Sr}$ & $\mathbf{V}$ & $\mathbf{Y}$ & Zn & $\mathrm{Zr}$ \\
\hline \multicolumn{15}{|c|}{ Andesite west of Lost Creek Glacier-Continued } \\
\hline 565 & 36 & 6 & 36 & 21 & 19 & 10 & 24 & 8 & 33 & 400 & 111 & 36 & 74 & 222 \\
\hline 558 & 38 & 7 & 31 & 22 & 21 & 11 & 21 & 11 & 34 & 401 & 104 & 37 & 77 & 222 \\
\hline 556 & 34 & 6 & 35 & 21 & 16 & 10 & 32 & 9 & 34 & 401 & 109 & 35 & 71 & 222 \\
\hline 556 & 36 & 7 & 31 & 21 & 19 & 10 & 17 & 8 & 32 & 398 & 114 & 32 & 74 & 219 \\
\hline 548 & 37 & $<5$ & 30 & 20 & 16 & 11 & 28 & 7 & 34 & 409 & 145 & 25 & 78 & 201 \\
\hline 562 & 37 & $<5$ & 34 & 22 & 15 & 10 & 23 & 8 & 33 & 395 & 110 & 34 & 74 & 221 \\
\hline 565 & 36 & 7 & 33 & 20 & 17 & 9 & 23 & 7 & 33 & 399 & 111 & 34 & 69 & 221 \\
\hline 559 & 37 & $<5$ & 27 & 22 & 19 & 10 & 17 & 8 & 33 & 399 & 118 & 32 & 74 & 216 \\
\hline 551 & 33 & 6 & 35 & 22 & 14 & 10 & 24 & 11 & 31 & 397 & 122 & 32 & 72 & 216 \\
\hline 559 & 34 & 8 & 31 & 20 & 16 & 10 & 19 & 9 & 33 & 397 & 108 & 34 & 74 & 218 \\
\hline 557 & 42 & 6 & 34 & 21 & 18 & 9 & 31 & 7 & 33 & 398 & 109 & 33 & 78 & 220 \\
\hline 567 & 35 & 11 & 34 & 20 & 20 & 9 & 22 & 9 & 33 & 394 & 117 & 30 & 75 & 218 \\
\hline 589 & 36 & 6 & 18 & 20 & 17 & 10 & $<10$ & 7 & 38 & 391 & 101 & 26 & 72 & 213 \\
\hline \multicolumn{15}{|c|}{ Andesite of Lewis Glacier headwall } \\
\hline 606 & 37 & $<5$ & 16 & 16 & 9 & 8 & 28 & 3 & 31 & 415 & 123 & 23 & 62 & 201 \\
\hline 574 & 36 & 4 & 23 & 20 & 20 & 9 & 19 & 0 & 36 & 399 & 120 & 26 & 81 & 194 \\
\hline 552 & 39 & 5 & 24 & 21 & 19 & 8 & 22 & 0 & 34 & 404 & 121 & 26 & 81 & 190 \\
\hline 556 & 36 & 6 & 23 & 20 & 20 & 8 & 19 & 0 & 34 & 407 & 120 & 27 & 80 & 192 \\
\hline \multicolumn{15}{|c|}{ Andesite south of Lewis Glacier } \\
\hline 566 & 30 & $<5$ & 20 & 13 & 10 & 8 & $<10$ & 3 & 31 & 404 & 147 & 21 & 59 & 187 \\
\hline \multicolumn{15}{|c|}{ Andesite agglutinate north of Hayden Glacier } \\
\hline 434 & 34 & $<5$ & 45 & 23 & 15 & 9 & 22 & 9 & 18 & 516 & 194 & 27 & 89 & 177 \\
\hline 516 & 64 & $<5$ & 42 & 22 & 72 & 15 & 44 & 25 & 25 & 540 & 282 & 43 & 114 & 198 \\
\hline \multicolumn{15}{|c|}{ Andesite of Obsidian Creek } \\
\hline 483 & 25 & 63 & 33 & 18 & 10 & 5 & 10 & 49 & 33 & 352 & 107 & 16 & 60 & 111 \\
\hline 422 & 20 & 75 & 47 & 17 & 9 & 5 & 15 & 48 & 28 & 384 & 125 & 17 & 64 & 106 \\
\hline 436 & 23 & 77 & 34 & 18 & 11 & 6 & 12 & 53 & 29 & 381 & 128 & 17 & 56 & 107 \\
\hline 487 & 21 & 69 & 35 & 16 & 11 & 6 & 15 & 40 & 34 & 351 & 116 & 17 & 56 & 111 \\
\hline 378 & 23 & 81 & 33 & 19 & 11 & 7 & 12 & na & 26 & 436 & 161 & 23 & 62 & 130 \\
\hline 486 & 23 & 67 & 43 & 22 & 13 & 8 & 12 & na & 35 & 374 & 149 & 22 & 63 & 137 \\
\hline 520 & 27 & 56 & 30 & 12 & 11 & 3 & $<10$ & 27 & 31 & 357 & 131 & 15 & 52 & 107 \\
\hline 518 & 22 & 54 & 32 & 11 & 11 & 4 & 18 & 44 & 28 & 369 & 133 & 15 & 48 & 104 \\
\hline 486 & 21 & 59 & 20 & 13 & 8 & 4 & $<10$ & 48 & 27 & 383 & 130 & 15 & 48 & 103 \\
\hline 557 & 26 & 51 & 28 & 11 & 10 & 5 & $<10$ & 39 & 33 & 348 & 118 & 14 & 48 & 109 \\
\hline 514 & 23 & 63 & 34 & 16 & 12 & 5 & 12 & 39 & 37 & 349 & 115 & 18 & 55 & 110 \\
\hline \multicolumn{15}{|c|}{ Andesite of Park Creek } \\
\hline 573 & 37 & $<5$ & 34 & 15 & 12 & 8 & 15 & 3 & 29 & 406 & 147 & 20 & 59 & 189 \\
\hline 518 & 35 & 14 & 36 & 18 & 16 & 8 & 19 & 8 & 32 & 404 & 165 & 24 & 75 & 183 \\
\hline 522 & 34 & 14 & 36 & 19 & 17 & 8 & 19 & 8 & 34 & 399 & 158 & 24 & 70 & 185 \\
\hline \multicolumn{15}{|c|}{ Andesite of Prouty Glacier headwall } \\
\hline 543 & 40 & 8 & 27 & 21 & 19 & 9 & 23 & 1 & 32 & 412 & 139 & 29 & 87 & 200 \\
\hline 537 & 39 & 5 & 23 & 19 & 18 & 9 & 23 & 1 & 32 & 397 & 133 & 29 & 88 & 204 \\
\hline \multicolumn{15}{|c|}{ Andesite tephra fall near base of Prouty Glacier headwall } \\
\hline 469 & 36 & 21 & 42 & 20 & 19 & 8 & 21 & 12 & 28 & 451 & 175 & 26 & 84 & 176 \\
\hline 538 & 38 & 8 & 25 & 21 & 17 & 10 & 21 & 3 & 30 & 408 & 154 & 28 & 81 & 199 \\
\hline 615 & 42 & 3 & 21 & 19 & 19 & 10 & 23 & 0 & 38 & 371 & 139 & 29 & 80 & 218 \\
\hline
\end{tabular}


Table 1. Chemical data for Three Sisters volcanic cluster.-Continued

\begin{tabular}{|c|c|c|c|c|c|c|c|c|c|c|c|c|c|c|}
\hline Sample & $\begin{array}{l}\text { Unit } \\
\text { label }\end{array}$ & $\begin{array}{c}\text { Volcanic } \\
\text { group }\end{array}$ & $\mathrm{SiO}_{2}$ & $\mathrm{TiO}_{2}$ & $\mathrm{Al}_{2} \mathrm{O}_{3}$ & $\mathrm{Fe} 0^{*}$ & Mno & Mg0 & $\mathrm{CaO}$ & $\mathrm{Na}_{2} \mathrm{O}$ & $\mathbf{K}_{\mathbf{2}} \mathbf{O}$ & $\mathbf{P}_{2} \mathbf{O}_{5}$ & LOI & $\begin{array}{c}\text { Original } \\
\text { total }\end{array}$ \\
\hline \multicolumn{15}{|c|}{ Andesite south of Newberry flow } \\
\hline TS-589 & asn & $\mathrm{SS}$ & 61.72 & 1.25 & 16.51 & 6.27 & 0.12 & 1.83 & 4.72 & 4.89 & 1.85 & 0.44 & 0.25 & 99.57 \\
\hline \multicolumn{15}{|c|}{ Andesite of southwest slope of Middle Sister } \\
\hline TS-225 & asw & MS & 61.53 & 1.13 & 16.99 & 6.22 & 0.14 & 1.93 & 4.61 & 5.24 & 1.45 & 0.36 & -0.01 & 99.06 \\
\hline TS-280 & asw & MS & 61.56 & 1.14 & 16.84 & 6.18 & 0.14 & 1.93 & 4.65 & 5.33 & 1.45 & 0.36 & -0.11 & 99.33 \\
\hline \multicolumn{15}{|c|}{ Hornblende-bearing andesite southeast of Yapoah Crater } \\
\hline TS-764 & asy & NS & 58.68 & 1.07 & 17.96 & 6.82 & 0.15 & 2.50 & 5.75 & 5.16 & 1.14 & 0.38 & na & 99.62 \\
\hline \multicolumn{15}{|c|}{ Avalanche blocks (in the debris-avalanche deposit unit) } \\
\hline TS-517 & av & s of BT & 57.99 & 1.05 & 17.36 & 7.15 & 0.11 & 3.80 & 6.87 & 3.78 & 1.20 & 0.29 & 1.75 & 97.56 \\
\hline TS-618 & av & $\mathrm{s}$ of BT & 57.24 & 1.09 & 17.62 & 7.15 & 0.12 & 3.70 & 6.94 & 4.28 & 1.21 & 0.24 & na & 97.63 \\
\hline \multicolumn{15}{|c|}{ Andesite west of upper Alder Creek } \\
\hline TS-655 & awa & NS & 57.53 & 1.53 & 16.80 & 8.14 & 0.14 & 2.97 & 6.15 & 4.76 & 1.26 & 0.33 & na & 99.26 \\
\hline TS-754 & awa & NS & 57.60 & 1.53 & 16.73 & 8.21 & 0.14 & 2.96 & 6.12 & 4.73 & 1.25 & 0.33 & na & 99.23 \\
\hline \multicolumn{15}{|c|}{ Andesite west of Collier Glacier } \\
\hline TS-367 & awc & MS & 62.17 & 1.27 & 16.12 & 6.45 & 0.14 & 1.78 & 4.46 & 5.18 & 1.58 & 0.45 & $<0.01$ & 99.48 \\
\hline TS-369 & awc & MS & 62.07 & 1.26 & 16.09 & 6.47 & 0.14 & 1.81 & 4.50 & 5.24 & 1.58 & 0.44 & $<0.01$ & 99.64 \\
\hline TS-371 & awc & MS & 62.00 & 1.26 & 16.20 & 6.43 & 0.14 & 1.81 & 4.41 & 5.31 & 1.60 & 0.43 & $<0.01$ & 99.59 \\
\hline TS-372 & awc & MS & 62.06 & 1.25 & 16.17 & 6.43 & 0.14 & 1.80 & 4.42 & 5.30 & 1.61 & 0.42 & $<0.01$ & 99.18 \\
\hline TS-374 & awc & MS & 62.25 & 1.26 & 16.01 & 6.42 & 0.14 & 1.81 & 4.43 & 5.22 & 1.59 & 0.45 & $<0.01$ & 99.51 \\
\hline TS-376 & awc & MS & 62.11 & 1.27 & 16.08 & 6.44 & 0.14 & 1.80 & 4.49 & 5.23 & 1.58 & 0.46 & $<0.01$ & 99.74 \\
\hline TS-377 & awc & MS & 61.63 & 1.33 & 16.16 & 6.56 & 0.14 & 1.90 & 4.51 & 5.30 & 1.62 & 0.45 & $<0.01$ & 98.59 \\
\hline TS-380 & awc & MS & 62.25 & 1.21 & 16.24 & 6.31 & 0.14 & 1.77 & 4.38 & 5.27 & 1.57 & 0.44 & $<0.01$ & 99.35 \\
\hline TS-392 & awc & MS & 62.12 & 1.25 & 16.10 & 6.41 & 0.14 & 1.79 & 4.44 & 5.32 & 1.59 & 0.44 & $<0.01$ & 99.58 \\
\hline TS-393 & awc & MS & 62.19 & 1.27 & 16.00 & 6.44 & 0.14 & 1.81 & 4.45 & 5.26 & 1.60 & 0.45 & 0.15 & 99.62 \\
\hline TS-394 & awc & MS & 62.18 & 1.27 & 16.07 & 6.42 & 0.14 & 1.80 & 4.43 & 5.24 & 1.62 & 0.44 & 0.55 & 99.16 \\
\hline TS-396 & awc & MS & 62.18 & 1.27 & 16.02 & 6.43 & 0.14 & 1.80 & 4.44 & 5.24 & 1.60 & 0.46 & 0.10 & 98.83 \\
\hline TS-399 & awc & MS & 62.00 & 1.26 & 16.08 & 6.44 & 0.14 & 1.85 & 4.48 & 5.35 & 1.59 & 0.43 & $<0.01$ & 99.13 \\
\hline \multicolumn{15}{|c|}{ Andesite of West Fork Park Creek } \\
\hline TS-506 & awf & SS & 59.58 & 1.22 & 16.84 & 6.98 & 0.13 & 3.05 & 5.94 & 4.11 & 1.42 & 0.33 & $<0.01$ & 99.97 \\
\hline TS-510 & awf & SS & 59.96 & 1.21 & 16.42 & 7.06 & 0.13 & 2.86 & 5.99 & 4.13 & 1.52 & 0.32 & $<0.01$ & 99.50 \\
\hline TS-518 & awf & SS & 59.66 & 1.23 & 16.67 & 7.06 & 0.12 & 2.76 & 6.21 & 4.10 & 1.48 & 0.32 & $<0.01$ & 99.17 \\
\hline TS-574 & awf & SS & 60.71 & 1.30 & 16.28 & 7.00 & 0.14 & 2.33 & 5.32 & 4.63 & 1.60 & 0.29 & $<0.01$ & 99.09 \\
\hline TS-576 & awf & SS & 60.26 & 1.19 & 16.39 & 6.81 & 0.12 & 2.76 & 5.75 & 4.39 & 1.61 & 0.33 & $<0.01$ & 99.66 \\
\hline TS-718 & awf & SS & 59.20 & 1.24 & 16.79 & 6.96 & 0.13 & 2.83 & 6.12 & 4.55 & 1.50 & 0.27 & na & 99.82 \\
\hline \multicolumn{15}{|c|}{ Andesite west of Middle Sister } \\
\hline TS-302 & awm & MS & 59.72 & 1.47 & 16.30 & 7.58 & 0.15 & 2.40 & 5.23 & 5.00 & 1.37 & 0.38 & -0.15 & 99.57 \\
\hline TS-303 & awm & MS & 60.21 & 1.44 & 16.36 & 7.23 & 0.15 & 2.25 & 5.02 & 5.14 & 1.42 & 0.39 & -0.19 & 99.25 \\
\hline TS-305 & awm & MS & 60.17 & 1.44 & 16.29 & 7.29 & 0.15 & 2.24 & 5.07 & 5.14 & 1.42 & 0.39 & -0.10 & 99.65 \\
\hline TS-306 & awm & MS & 60.28 & 1.43 & 16.27 & 7.22 & 0.15 & 2.27 & 5.05 & 5.14 & 1.42 & 0.39 & -0.16 & 99.80 \\
\hline TS-307 & awm & MS & 59.11 & 1.50 & 16.52 & 7.76 & 0.15 & 2.46 & 5.46 & 4.94 & 1.31 & 0.39 & 0.58 & 98.90 \\
\hline TS-416 & awm & MS & 59.23 & 1.52 & 16.49 & 7.89 & 0.15 & 2.51 & 5.52 & 4.57 & 1.32 & 0.41 & 0.40 & 99.05 \\
\hline TS-418 & awm & MS & 60.62 & 1.42 & 16.33 & 7.21 & 0.15 & 2.21 & 4.97 & 4.81 & 1.45 & 0.42 & $<0.01$ & 99.40 \\
\hline TS-420 & awm & MS & 60.54 & 1.43 & 16.39 & 7.18 & 0.15 & 2.21 & 5.05 & 4.81 & 1.43 & 0.42 & 1.49 & 99.05 \\
\hline TS-425 & awm & MS & 59.76 & 1.48 & 16.40 & 7.58 & 0.15 & 2.42 & 5.33 & 4.71 & 1.36 & 0.41 & $<0.01$ & 99.01 \\
\hline \multicolumn{15}{|c|}{ Andesite west of Renfrew Glacier } \\
\hline TS-400 & awr & MS & 60.94 & 1.37 & 16.13 & 6.99 & 0.14 & 2.12 & 4.92 & 5.09 & 1.45 & 0.44 & $<0.01$ & 100.02 \\
\hline TS-401 & awr & MS & 60.83 & 1.41 & 16.16 & 7.04 & 0.14 & 2.13 & 4.98 & 5.04 & 1.45 & 0.43 & $<0.01$ & 99.87 \\
\hline TS-408 & awr & MS & 61.48 & 1.33 & 16.37 & 6.73 & 0.14 & 2.00 & 4.70 & 4.89 & 1.53 & 0.44 & $<0.01$ & 99.79 \\
\hline TS-413 & awr & MS & 61.39 & 1.32 & 16.40 & 6.78 & 0.14 & 2.03 & 4.69 & 4.90 & 1.52 & 0.44 & $<0.01$ & 99.62 \\
\hline
\end{tabular}




\begin{tabular}{|c|c|c|c|c|c|c|c|c|c|c|c|c|c|c|}
\hline $\mathrm{Ba}$ & $\mathrm{Ce}$ & $\mathrm{Cr}$ & $\mathrm{Cu}$ & Ga & La & $\mathrm{Nb}$ & Nd & $\mathbf{N i}$ & $\mathbf{R b}$ & Sr & $\mathbf{V}$ & $\mathbf{Y}$ & Zn & $\mathrm{Zr}$ \\
\hline \multicolumn{15}{|c|}{ Andesite south of Newberry flow } \\
\hline \multicolumn{15}{|c|}{ Andesite of southwest slope of Middle Sister } \\
\hline 548 & 37 & $<5$ & 19 & 21 & 15 & 10 & 23 & 6 & 22 & 488 & 77 & 32 & 90 & 191 \\
\hline 431 & 38 & 1 & 22 & 21 & 17 & 10 & 22 & 5 & 13 & 557 & 110 & 28 & 96 & 175 \\
\hline \multicolumn{15}{|c|}{ Avalanche blocks (in the debris-avalanche deposit unit) } \\
\hline na & na & na & na & na & na & na & na & na & na & na & na & na & na & na \\
\hline 400 & 34 & 37 & 77 & 20 & 17 & 7 & 19 & 20 & 22 & 577 & 184 & 24 & 79 & 143 \\
\hline \multicolumn{15}{|c|}{ Andesite west of Collier Glacier } \\
\hline 614 & 43 & $<5$ & 9 & 15 & 16 & 8 & 19 & 3 & 26 & 422 & $<5$ & 29 & 82 & 211 \\
\hline 603 & 41 & $<5$ & 9 & 16 & 16 & 9 & 21 & 3 & 27 & 429 & 96 & 30 & 83 & 213 \\
\hline 630 & 62 & na & 22 & 32 & 35 & 13 & 34 & na & 31 & 481 & 119 & 40 & 120 & 279 \\
\hline 577 & 39 & na & 19 & 24 & 16 & 13 & 28 & na & 27 & 450 & 131 & 45 & 100 & 271 \\
\hline 623 & 42 & $<5$ & 8 & 17 & 17 & 9 & 30 & 3 & 25 & 419 & 97 & 31 & 84 & 214 \\
\hline 610 & 41 & $<5$ & 3 & 17 & 14 & 8 & 37 & 3 & 26 & 434 & 96 & 30 & 81 & 209 \\
\hline 574 & 39 & na & 18 & 23 & 20 & 13 & 22 & na & 29 & 446 & 129 & 45 & 99 & 271 \\
\hline 617 & 42 & $<5$ & 6 & 16 & 14 & 9 & 23 & 3 & 25 & 432 & 77 & 29 & 86 & 206 \\
\hline 575 & 39 & na & 20 & 24 & 22 & 13 & 25 & na & 27 & 453 & 124 & 45 & 89 & 268 \\
\hline na & na & na & na & na & na & na & na & na & na & na & na & na & na & na \\
\hline na & na & na & na & na & na & na & na & na & na & na & na & na & na & na \\
\hline 542 & 36 & $<5$ & 3 & 14 & 12 & 11 & 13 & 3 & 28 & 432 & 185 & 28 & 64 & 227 \\
\hline 542 & 35 & $<5$ & 32 & 15 & 11 & 8 & $<10$ & 4 & 27 & 427 & 153 & 21 & 66 & 186 \\
\hline 476 & 30 & 21 & 37 & 20 & 18 & 8 & 18 & 13 & 26 & 448 & 179 & 26 & 78 & 173 \\
\hline \multicolumn{15}{|c|}{ Andesite west of Middle Sister } \\
\hline 495 & 33 & $<5$ & 30 & 22 & 15 & 10 & 24 & 8 & 23 & 453 & 143 & 35 & 88 & 191 \\
\hline 511 & 38 & $<5$ & 24 & 22 & 17 & 9 & 23 & 7 & 23 & 446 & 120 & 36 & 92 & 199 \\
\hline 506 & 36 & $<5$ & 24 & 22 & 15 & 10 & 26 & 8 & 23 & 448 & 130 & 35 & 89 & 192 \\
\hline 512 & 36 & $<5$ & 29 & 23 & 16 & 11 & 14 & 7 & 23 & 453 & 131 & 35 & 93 & 196 \\
\hline 477 & 36 & $<5$ & 44 & 22 & 16 & 10 & 23 & 6 & 21 & 456 & 154 & 33 & 95 & 189 \\
\hline 512 & 39 & $<5$ & 30 & 17 & 12 & 8 & $<10$ & 3 & 21 & 459 & 156 & 28 & 83 & 187 \\
\hline 562 & 41 & $<5$ & 11 & 17 & 12 & 8 & 22 & 3 & 25 & 450 & 126 & 29 & 82 & 200 \\
\hline 565 & 42 & $<5$ & 17 & 17 & 15 & 8 & 17 & 3 & 23 & 451 & 128 & 29 & 79 & 199 \\
\hline 546 & 39 & $<5$ & 25 & 17 & 12 & 7 & 29 & 3 & 23 & 451 & 149 & 27 & 81 & 187 \\
\hline \multicolumn{15}{|c|}{ Andesite west of Renfrew Glacier } \\
\hline 572 & 43 & $<5$ & 15 & 16 & 15 & 8 & $<10$ & 3 & 24 & 439 & 123 & 29 & 81 & 197 \\
\hline 567 & 38 & $<5$ & 11 & 16 & 14 & 8 & 31 & 3 & 24 & 449 & 119 & 28 & 80 & 197 \\
\hline 595 & 40 & $<5$ & 11 & 16 & 13 & 8 & 29 & 3 & 24 & 433 & 100 & 31 & 82 & 206 \\
\hline 589 & 39 & $<5$ & 15 & 17 & 15 & 8 & 31 & 3 & 25 & 436 & 105 & 30 & 81 & 206 \\
\hline
\end{tabular}


Table 1. Chemical data for Three Sisters volcanic cluster.-Continued

\begin{tabular}{|c|c|c|c|c|c|c|c|c|c|c|c|c|c|c|}
\hline Sample & $\begin{array}{l}\text { Unit } \\
\text { label }\end{array}$ & $\begin{array}{c}\text { Volcanic } \\
\text { group }\end{array}$ & $\mathrm{SiO}_{2}$ & $\mathrm{TiO}_{2}$ & $\mathrm{Al}_{2} \mathrm{O}_{3}$ & $\mathrm{Fe} 0 *$ & MnO & MgO & $\mathrm{CaO}$ & $\mathrm{Na}_{2} \mathrm{O}$ & $\mathrm{K}_{2} \mathrm{O}$ & $\mathrm{P}_{2} \mathrm{O}_{5}$ & LOI & $\begin{array}{c}\text { Original } \\
\text { total }\end{array}$ \\
\hline \multicolumn{15}{|c|}{ Andesite west of Renfrew Glacier-Continued } \\
\hline TS-414 & awr & MS & 61.58 & 1.33 & 16.37 & 6.70 & 0.14 & 1.98 & 4.61 & 4.92 & 1.55 & 0.42 & 0.06 & 99.15 \\
\hline TS-415 & awr & MS & 61.27 & 1.34 & 16.39 & 6.86 & 0.15 & 2.02 & 4.68 & 4.93 & 1.53 & 0.44 & $<0.01$ & 99.65 \\
\hline \multicolumn{15}{|c|}{ Andesite of Whychus Creek } \\
\hline TS-439 & awy & $\mathrm{BT}$ & 61.68 & 1.11 & 16.81 & 6.01 & 0.09 & 2.13 & 5.29 & 4.27 & 1.79 & 0.43 & 0.03 & 11.67 \\
\hline TS-452 & awy & BT & 62.03 & 1.11 & 16.69 & 5.94 & 0.11 & 2.08 & 5.15 & 4.30 & 1.87 & 0.32 & 0.34 & 99.06 \\
\hline TS-453 & awy & $\mathrm{BT}$ & 61.30 & 1.08 & 17.13 & 6.04 & 0.13 & 1.97 & 4.98 & 5.06 & 1.56 & 0.34 & 0.17 & 99.43 \\
\hline \multicolumn{15}{|c|}{ Basalt of Alder Creek } \\
\hline TS-601 & bac & NS & 51.23 & 1.44 & 17.23 & 9.13 & 0.16 & 7.49 & 8.39 & 3.61 & 0.61 & 0.30 & na & 98.38 \\
\hline TS-652 & bac & NS & 53.11 & 1.32 & 18.09 & 8.13 & 0.15 & 5.28 & 8.58 & 3.78 & 0.81 & 0.35 & na & 97.56 \\
\hline \multicolumn{15}{|c|}{ Basalt of Brush Draw } \\
\hline TS-528 & bbd & NS & 51.06 & 1.34 & 18.73 & 8.11 & 0.14 & 5.48 & 10.37 & 3.36 & 0.65 & 0.34 & 0.20 & 98.90 \\
\hline TS-615 & bbd & NS & 51.44 & 1.29 & 18.39 & 7.94 & 0.14 & 5.53 & 10.39 & 3.38 & 0.76 & 0.34 & na & 100.16 \\
\hline TS-615R & bbd & NS & 51.41 & 1.30 & 18.40 & 7.89 & 0.14 & 5.58 & 10.40 & 3.37 & 0.76 & 0.34 & na & 99.66 \\
\hline \multicolumn{15}{|c|}{ Basalt of Sparks Lake boat ramp } \\
\hline TS-672 & bbr & $\mathrm{P}$ & 50.75 & 1.36 & 17.52 & 8.64 & 0.15 & 7.93 & 9.07 & 3.31 & 0.61 & 0.26 & na & 99.50 \\
\hline TS-673 & $\mathrm{bbr}$ & $\mathrm{P}$ & 51.02 & 1.30 & 17.24 & 8.38 & 0.16 & 8.06 & 9.17 & 3.34 & 0.65 & 0.27 & na & 100.34 \\
\hline TS-674 & bbr & $\mathrm{P}$ & 51.46 & 1.21 & 17.47 & 8.19 & 0.15 & 7.45 & 9.43 & 3.34 & 0.64 & 0.25 & na & 99.40 \\
\hline TS-771 & bbr & $\mathrm{P}$ & 51.20 & 1.31 & 17.03 & 8.50 & 0.15 & 7.98 & 9.10 & 3.39 & 0.66 & 0.27 & na & 99.76 \\
\hline TS-772 & bbr & $\mathrm{P}$ & 51.49 & 1.22 & 17.52 & 8.30 & 0.15 & 7.30 & 9.45 & 3.32 & 0.59 & 0.25 & na & 99.81 \\
\hline TS-773 & $\mathrm{bbr}$ & $\mathrm{P}$ & 51.39 & 1.28 & 17.27 & 8.33 & 0.15 & 7.68 & 9.23 & 3.36 & 0.65 & 0.27 & na & 99.53 \\
\hline
\end{tabular}

\begin{tabular}{|c|c|c|c|c|c|c|c|c|c|c|c|c|c|c|}
\hline \multicolumn{15}{|c|}{ Basalt of Cayuse Crater } \\
\hline TS-625 & bcc & $\mathrm{P}$ & 51.72 & 1.07 & 16.57 & 8.42 & 0.15 & 8.65 & 9.07 & 3.11 & 0.61 & 0.22 & na & 99.99 \\
\hline TS-626 & bcc & $\mathrm{P}$ & 51.79 & 1.06 & 16.47 & 8.36 & 0.15 & 8.69 & 9.11 & 3.12 & 0.64 & 0.21 & na & 100.21 \\
\hline TS-627 & bcc & $\mathrm{P}$ & 51.90 & 1.05 & 16.40 & 8.39 & 0.15 & 8.66 & 9.06 & 3.12 & 0.65 & 0.21 & na & 100.63 \\
\hline CR-42 & bcc & $\mathrm{P}$ & 51.48 & 1.04 & 16.26 & 8.70 & 0.15 & 8.74 & 9.40 & 2.97 & 0.65 & 0.21 & na & 99.83 \\
\hline \multicolumn{15}{|c|}{ Basalt east of Sparks Lake } \\
\hline TS-671 & bes & $\mathrm{P}$ & 49.77 & 1.49 & 17.89 & 9.58 & 0.16 & 7.32 & 9.17 & 3.63 & 0.38 & 0.22 & na & 100.17 \\
\hline TS-770 & bes & $\mathrm{P}$ & 49.72 & 1.50 & 17.50 & 9.70 & 0.16 & 7.75 & 9.12 & 3.49 & 0.41 & 0.24 & na & 100.28 \\
\hline CR-40 & bes & $\mathrm{P}$ & 49.33 & 1.48 & 17.74 & 10.16 & 0.16 & 7.40 & 9.30 & 3.46 & 0.35 & 0.22 & na & 99.95 \\
\hline \multicolumn{15}{|c|}{ Basalt south of The Husband } \\
\hline TS-121 & bhs & $\mathrm{P}$ & 52.97 & 1.40 & 17.76 & 8.34 & 0.14 & 5.02 & 8.57 & 3.87 & 0.99 & 0.54 & -0.26 & 99.29 \\
\hline TS-122 & bhs & $\mathrm{P}$ & 51.11 & 1.39 & 17.20 & 8.85 & 0.15 & 6.91 & 9.52 & 3.37 & 0.72 & 0.37 & -0.26 & 99.57 \\
\hline TS-123 & bhs & $\mathrm{P}$ & 52.89 & 1.20 & 18.00 & 8.18 & 0.14 & 5.80 & 8.62 & 3.53 & 0.89 & 0.35 & 0.00 & 99.06 \\
\hline TS-124 & bhs & $\mathrm{P}$ & 51.38 & 1.50 & 17.53 & 8.56 & 0.15 & 6.61 & 9.34 & 3.39 & 0.80 & 0.34 & -0.04 & 99.44 \\
\hline TS-126 & bhs & $\mathrm{P}$ & 52.50 & 1.40 & 17.33 & 8.62 & 0.15 & 5.99 & 8.50 & 3.67 & 0.98 & 0.47 & -0.35 & 99.99 \\
\hline TS-152 & bhs & $\mathrm{P}$ & 52.49 & 1.22 & 18.06 & 8.21 & 0.14 & 6.08 & 8.72 & 3.47 & 0.84 & 0.35 & 0.20 & 99.25 \\
\hline TS-153 & bhs & $\mathrm{P}$ & 52.68 & 1.41 & 17.93 & 8.40 & 0.14 & 5.14 & 8.60 & 3.83 & 0.94 & 0.53 & 0.01 & 99.45 \\
\hline \multicolumn{15}{|c|}{ Basalt of James Creek } \\
\hline TS-110 & bjc & $\mathrm{P}$ & 51.78 & 1.37 & 17.36 & 8.50 & 0.15 & 6.81 & 9.15 & 3.40 & 0.75 & 0.32 & -0.21 & 99.26 \\
\hline TS-116 & bjc & $\mathrm{P}$ & 51.54 & 1.28 & 17.45 & 8.70 & 0.15 & 7.14 & 8.93 & 3.41 & 0.68 & 0.32 & -0.14 & 99.34 \\
\hline TS-119 & bjc & $\mathrm{P}$ & 51.62 & 1.42 & 17.47 & 8.52 & 0.15 & 6.79 & 9.26 & 3.32 & 0.73 & 0.32 & 0.07 & 99.18 \\
\hline \multicolumn{15}{|c|}{ Basalt of North Fork Whychus Creek } \\
\hline TS-434 & bnf & $\mathrm{P}$ & 51.09 & 0.98 & 21.99 & 6.67 & 0.11 & 4.35 & 10.80 & 2.98 & 0.41 & 0.22 & 0.06 & 99.62 \\
\hline TS-503 & bnf & $\mathrm{P}$ & 52.51 & 1.25 & 20.15 & 7.71 & 0.13 & 4.15 & 9.69 & 3.17 & 0.57 & 0.28 & 0.01 & 100.34 \\
\hline TS-526 & bnf & $\mathrm{P}$ & 50.92 & 1.03 & 21.80 & 6.86 & 0.13 & 4.29 & 10.65 & 3.30 & 0.44 & 0.17 & 0.01 & 99.16 \\
\hline
\end{tabular}

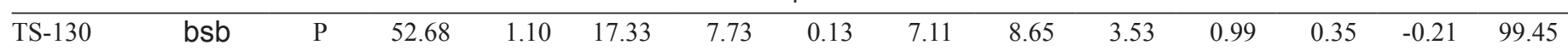




\begin{tabular}{|c|c|c|c|c|c|c|c|c|c|c|c|c|c|c|}
\hline $\mathrm{Ba}$ & $\mathrm{Ce}$ & $\mathrm{Cr}$ & $\mathrm{Cu}$ & Ga & La & $\mathbf{N b}$ & Nd & $\mathrm{Ni}$ & $\mathbf{R b}$ & $\mathrm{Sr}$ & v & $\mathbf{Y}$ & Zn & $\mathrm{Zr}$ \\
\hline \multicolumn{15}{|c|}{ Andesite west of Renfrew Glacier-Continued } \\
\hline 596 & 40 & $<5$ & 13 & 16 & 18 & 9 & $<10$ & 3 & 23 & 427 & $<5$ & 29 & 82 & 208 \\
\hline 593 & 41 & $<5$ & 11 & 17 & 17 & 9 & 20 & 3 & 25 & 437 & 113 & 31 & 83 & 208 \\
\hline \multicolumn{15}{|c|}{ Andesite of Whychus Creek } \\
\hline 590 & 38 & $<5$ & 21 & 16 & 12 & 7 & 29 & 3 & 34 & 414 & 136 & 22 & 62 & 200 \\
\hline 607 & 34 & $<5$ & 20 & 16 & 13 & 8 & 31 & 3 & 35 & 404 & 117 & 23 & 63 & 200 \\
\hline 567 & 40 & $<5$ & 12 & 17 & 13 & 8 & 19 & 3 & 26 & 529 & 107 & 27 & 60 & 194 \\
\hline \multicolumn{15}{|c|}{ Basalt of Alder Creek } \\
\hline 265 & 26 & 256 & 60 & 18 & 8 & 6 & 17 & 151 & 8 & 476 & 200 & 24 & 85 & 117 \\
\hline 323 & 28 & 84 & 65 & 19 & 14 & 9 & 20 & 57 & 11 & 504 & 192 & 25 & 84 & 150 \\
\hline \multicolumn{15}{|c|}{ Basalt of Brush Draw } \\
\hline 402 & 39 & 96 & 78 & 15 & 10 & 7 & 20 & 38 & 3 & 726 & 212 & 19 & 63 & 123 \\
\hline 363 & 37 & 126 & 86 & 18 & 15 & 8 & 21 & 41 & 10 & 720 & 216 & 23 & 74 & 124 \\
\hline 366 & 39 & 126 & 84 & 18 & 17 & 8 & 23 & 41 & 9 & 714 & 213 & 23 & 75 & 123 \\
\hline \multicolumn{15}{|c|}{ Basalt of Sparks Lake boat ramp } \\
\hline 215 & 27 & 269 & 67 & 17 & 9 & 9 & 16 & 155 & 10 & 450 & 190 & 24 & 78 & 128 \\
\hline 222 & 24 & 292 & 67 & 17 & 10 & 7 & 16 & 159 & 11 & 427 & 200 & 25 & 78 & 131 \\
\hline 225 & 27 & 221 & 74 & 17 & 11 & 7 & 17 & 127 & 11 & 419 & 202 & 25 & 77 & 121 \\
\hline 220 & 24 & 281 & 70 & 17 & 11 & 8 & 17 & 159 & 12 & 434 & 198 & 26 & 77 & 130 \\
\hline 237 & 31 & 216 & 73 & 18 & 12 & 8 & 17 & 125 & 12 & 433 & 195 & 27 & 74 & 122 \\
\hline 227 & 26 & 248 & 74 & 18 & 13 & 9 & 17 & 145 & 12 & 438 & 201 & 27 & 74 & 126 \\
\hline \multicolumn{15}{|c|}{ Basalt of Cayuse Crater } \\
\hline 230 & 23 & 434 & 65 & 17 & 10 & 6 & 14 & 158 & 10 & 454 & 199 & 20 & 79 & 101 \\
\hline 231 & 23 & 445 & 65 & 18 & 14 & 6 & 12 & 157 & 11 & 454 & 200 & 20 & 77 & 99 \\
\hline 225 & 23 & 447 & 62 & 16 & 11 & 6 & 14 & 155 & 12 & 451 & 200 & 19 & 76 & 99 \\
\hline na & na & na & na & na & na & na & na & na & na & na & na & na & na & na \\
\hline \multicolumn{15}{|c|}{ Basalt east of Sparks Lake } \\
\hline 152 & 18 & 152 & 70 & 18 & 8 & 3 & 14 & 117 & 5 & 413 & 203 & 24 & 85 & 106 \\
\hline 158 & 26 & 207 & 65 & 17 & 7 & 7 & 16 & 140 & 6 & 417 & 205 & 27 & 80 & 113 \\
\hline na & na & na & na & na & na & na & na & na & na & na & na & na & na & na \\
\hline
\end{tabular}

\begin{tabular}{|c|c|c|c|c|c|c|c|c|c|c|c|c|c|c|}
\hline na & na & na & na & na & na & na & na & na & na & na & na & na & na & na \\
\hline \multicolumn{15}{|c|}{ Basalt south of The Husband } \\
\hline na & na & na & na & na & na & na & na & na & na & na & na & na & na & na \\
\hline na & na & na & na & na & na & na & na & na & na & na & na & na & na & na \\
\hline na & na & na & na & na & na & na & na & na & na & na & na & na & na & na \\
\hline na & na & na & na & na & na & na & na & na & na & na & na & na & na & na \\
\hline na & na & na & na & na & na & na & na & na & na & na & na & na & na & na \\
\hline na & na & na & na & na & na & na & na & na & na & na & na & na & na & na \\
\hline na & na & na & na & na & na & na & na & na & na & na & na & na & na & na \\
\hline \multicolumn{15}{|c|}{ Basalt of James Creek } \\
\hline na & na & na & na & na & na & na & na & na & na & na & na & na & na & na \\
\hline na & na & na & na & na & na & na & na & na & na & na & na & na & na & na \\
\hline na & na & na & na & na & na & na & na & na & na & na & na & na & na & na \\
\hline
\end{tabular}

\section{Basalt of North Fork Whychus Creek}

\begin{tabular}{|c|c|c|c|c|c|c|c|c|c|c|c|c|c|c|}
\hline 187 & 12 & 74 & 35 & 15 & 7 & 3 & $<10$ & 13 & 3 & 642 & 157 & 12 & 51 & 70 \\
\hline 226 & 17 & 34 & 46 & 15 & 9 & 5 & $<10$ & 11 & 7 & 581 & 174 & 18 & 58 & 91 \\
\hline 187 & 14 & 72 & 42 & 15 & 5 & 3 & $<10$ & 28 & 4 & 627 & 161 & 12 & 47 & 71 \\
\hline \multicolumn{15}{|c|}{ Basalt of Sphinx Butte } \\
\hline na & na & na & na & na & na & na & na & na & na & na & na & na & na & na \\
\hline
\end{tabular}


Table 1. Chemical data for Three Sisters volcanic cluster.-Continued

\begin{tabular}{|c|c|c|c|c|c|c|c|c|c|c|c|c|c|c|}
\hline Sample & $\begin{array}{l}\text { Unit } \\
\text { label }\end{array}$ & $\begin{array}{c}\text { Volcanic } \\
\text { group }\end{array}$ & $\mathrm{SiO}_{2}$ & $\mathrm{TiO}_{2}$ & $\mathrm{Al}_{2} \mathrm{O}_{3}$ & $\mathrm{FeO}$ * & MnO & MgO & $\mathrm{CaO}$ & $\mathrm{Na}_{2} \mathrm{O}$ & $\mathrm{K}_{2} \mathbf{O}$ & $\mathbf{P}_{2} \mathbf{O}_{5}$ & LOI & $\begin{array}{c}\text { Original } \\
\text { total }\end{array}$ \\
\hline \multicolumn{15}{|c|}{ Basalt of Sphinx Butte-Continued } \\
\hline TS-131 & bsb & $\mathrm{P}$ & 51.52 & 1.10 & 16.94 & 8.22 & 0.14 & 8.02 & 9.27 & 3.32 & 0.77 & 0.30 & 0.43 & 98.80 \\
\hline TS-132 & bsb & $\mathrm{P}$ & 51.25 & 1.43 & 17.15 & 8.90 & 0.15 & 6.71 & 9.45 & 3.42 & 0.76 & 0.38 & 0.23 & 98.74 \\
\hline \multicolumn{15}{|c|}{ Basalt southeast of Sparks Lake } \\
\hline TS-769 & bsl & $\mathrm{P}$ & 51.10 & 1.21 & 17.74 & 8.28 & 0.14 & 7.88 & 9.09 & 3.38 & 0.56 & 0.22 & na & 99.98 \\
\hline \multicolumn{15}{|c|}{ Basalt of Spruce Spring } \\
\hline CR-116 & bss & $\mathrm{P}$ & 50.11 & 1.56 & 17.34 & 9.33 & 0.15 & 7.41 & 9.24 & 3.39 & 0.68 & 0.40 & na & 99.97 \\
\hline TS-527 & bss & $\mathrm{P}$ & 50.35 & 1.64 & 17.45 & 9.26 & 0.17 & 7.15 & 9.07 & 3.39 & 0.72 & 0.40 & $<0.01$ & 99.31 \\
\hline TS-592 & bss & $\mathrm{P}$ & 50.00 & 1.49 & 17.77 & 8.89 & 0.16 & 7.75 & 9.08 & 3.45 & 0.62 & 0.37 & na & 98.29 \\
\hline TS-592R & bss & $\mathrm{P}$ & 50.07 & 1.49 & 17.77 & 8.87 & 0.16 & 7.75 & 9.06 & 3.45 & 0.62 & 0.37 & na & 98.89 \\
\hline \multicolumn{15}{|c|}{ Basalt and basaltic andesite of Talapus and Katsuk Buttes } \\
\hline TS-346 & btk & $\mathrm{P}$ & 53.44 & 1.31 & 17.81 & 8.94 & 0.15 & 5.10 & 8.05 & 3.74 & 0.69 & 0.36 & $<0.01$ & 99.53 \\
\hline TS-347 & btk & $\mathrm{P}$ & 51.66 & 1.31 & 16.85 & 8.75 & 0.15 & 7.42 & 9.10 & 3.30 & 0.66 & 0.38 & $<0.01$ & 99.28 \\
\hline TS-642 & btk & $\mathrm{P}$ & 51.66 & 1.37 & 16.93 & 8.64 & 0.16 & 7.38 & 9.02 & 3.43 & 0.68 & 0.33 & na & 99.85 \\
\hline \multicolumn{15}{|c|}{ Basalt of lower Whychus Creek } \\
\hline TS-617 & bwl & $\mathrm{P}$ & 50.77 & 1.49 & 17.44 & 8.99 & 0.16 & 7.32 & 8.85 & 3.56 & 0.65 & 0.37 & na & 100.65 \\
\hline \multicolumn{15}{|c|}{ Basalt west of Millican Crater } \\
\hline TS-727 & bwm & $\mathrm{P}$ & 50.56 & 1.67 & 17.70 & 8.97 & 0.16 & 6.44 & 9.43 & 3.62 & 0.71 & 0.35 & na & 100.37 \\
\hline TS-729 & bwm & $\mathrm{P}$ & 49.84 & 1.55 & 16.81 & 9.28 & 0.16 & 8.63 & 8.98 & 3.37 & 0.65 & 0.33 & na & 100.55 \\
\hline TS-730 & bwm & $\mathrm{P}$ & 49.53 & 1.53 & 16.72 & 9.43 & 0.16 & 9.13 & 8.80 & 3.35 & 0.63 & 0.33 & na & 100.08 \\
\hline TS-734 & bwm & $\mathrm{P}$ & 50.26 & 1.58 & 17.17 & 9.20 & 0.16 & 7.64 & 9.11 & 3.50 & 0.64 & 0.34 & na & 99.72 \\
\hline TS-743 & bwm & $\mathrm{P}$ & 50.13 & 1.56 & 17.14 & 9.27 & 0.16 & 7.84 & 9.14 & 3.42 & 0.60 & 0.34 & na & 99.88 \\
\hline TS-744 & bwm & $\mathrm{P}$ & 50.52 & 1.64 & 17.61 & 9.13 & 0.16 & 6.55 & 9.37 & 3.60 & 0.67 & 0.35 & na & 100.21 \\
\hline NS-07-198 & bwm & $\mathrm{P}$ & 49.82 & 1.55 & 16.57 & 9.40 & 0.16 & 8.92 & 8.84 & 3.38 & 0.63 & 0.33 & na & 100.69 \\
\hline NS-07-206 & bwm & $\mathrm{P}$ & 49.48 & 1.49 & 16.21 & 9.54 & 0.16 & 9.85 & 8.63 & 3.29 & 0.62 & 0.32 & na & 100.64 \\
\hline \multicolumn{15}{|c|}{ Basalt of Whychus Creek } \\
\hline TS-458 & bwy & BT & 51.11 & 1.23 & 17.14 & 8.93 & 0.15 & 7.92 & 9.18 & 2.94 & 0.70 & 0.31 & $<0.01$ & 99.39 \\
\hline TS-500 & bwy & BT & 51.71 & 1.35 & 18.63 & 8.99 & 0.15 & 5.95 & 8.72 & 3.31 & 0.49 & 0.31 & $<0.01$ & 99.97 \\
\hline TS-676 & bwy & BT & 51.83 & 1.39 & 18.56 & 8.65 & 0.15 & 5.76 & 8.60 & 3.86 & 0.54 & 0.26 & na & 100.19 \\
\hline \multicolumn{15}{|c|}{ Dacite of "Black Hump" } \\
\hline TS-100 & $\mathrm{dbh}$ & MS & 64.04 & 0.91 & 16.41 & 5.44 & 0.14 & 1.23 & 3.42 & 5.93 & 1.70 & 0.38 & $<0.01$ & 99.54 \\
\hline TS-215 & $\mathrm{dbh}$ & MS & 64.47 & 0.93 & 16.04 & 5.51 & 0.14 & 1.27 & 3.35 & 5.79 & 1.73 & 0.36 & -0.11 & 99.34 \\
\hline TS-215A & $\mathrm{dbh}$ & MS & 64.24 & 0.95 & 16.09 & 5.52 & 0.14 & 1.32 & 3.41 & 5.84 & 1.74 & 0.36 & 0.43 & 99.07 \\
\hline TS-216 & $\mathrm{dbh}$ & MS & 64.35 & 0.92 & 16.16 & 5.50 & 0.14 & 1.29 & 3.40 & 5.75 & 1.72 & 0.36 & -0.13 & 99.21 \\
\hline TS-368 & $\mathrm{dbh}$ & MS & 64.47 & 0.93 & 15.94 & 5.54 & 0.14 & 1.23 & 3.38 & 5.83 & 1.73 & 0.40 & 0.21 & 99.33 \\
\hline TS-370 & $\mathrm{dbh}$ & MS & 64.36 & 0.95 & 15.97 & 5.56 & 0.14 & 1.29 & 3.44 & 5.76 & 1.72 & 0.42 & 0.07 & 99.81 \\
\hline TS-397 & $\mathrm{dbh}$ & MS & 64.38 & 0.93 & 15.94 & 5.52 & 0.14 & 1.27 & 3.45 & 5.84 & 1.71 & 0.41 & 0.26 & 99.33 \\
\hline TS-405 & $\mathrm{dbh}$ & MS & 64.05 & 0.98 & 16.31 & 5.62 & 0.14 & 1.38 & 3.63 & 5.40 & 1.67 & 0.40 & $<0.01$ & 99.52 \\
\hline \multicolumn{15}{|c|}{ Dacite breccia of Lewis Glacier headwall } \\
\hline TS-582 & $\mathrm{dbl}$ & SS & 62.83 & 1.09 & 16.39 & 5.92 & 0.12 & 2.00 & 4.58 & 4.30 & 1.99 & 0.36 & 2.06 & 98.44 \\
\hline TS-582-2 & $\mathrm{dbl}$ & SS & 62.62 & 1.08 & 16.25 & 5.88 & 0.12 & 2.05 & 4.63 & 4.62 & 2.08 & 0.27 & n.d. & 97.39 \\
\hline TS-691 & $\mathrm{dbl}$ & $\mathrm{SS}$ & 62.60 & 1.10 & 16.22 & 5.86 & 0.12 & 2.07 & 4.69 & 4.64 & 2.01 & 0.27 & na & 97.80 \\
\hline \multicolumn{15}{|c|}{ Dacite southwest of Clark Glacier } \\
\hline TS-71 & dcg & SS & 63.23 & 1.08 & 16.33 & 5.57 & 0.11 & 1.71 & 4.30 & 4.94 & 1.98 & 0.36 & $<0.01$ & 100.03 \\
\hline TS-117 & dcg & SS & 63.31 & 1.10 & 16.18 & 5.66 & 0.11 & 1.72 & 4.24 & 4.94 & 2.00 & 0.34 & -0.01 & 99.12 \\
\hline TS-120 & dcg & $\mathrm{SS}$ & 63.36 & 1.11 & 16.09 & 5.61 & 0.11 & 1.74 & 4.29 & 4.96 & 1.98 & 0.34 & -0.06 & 99.03 \\
\hline TS-133 & dcg & SS & 63.19 & 1.09 & 16.17 & 5.64 & 0.11 & 1.80 & 4.31 & 4.96 & 1.98 & 0.34 & -0.56 & 99.15 \\
\hline TS-134 & dcg & SS & 63.22 & 1.10 & 16.18 & 5.64 & 0.11 & 1.76 & 4.30 & 4.96 & 1.99 & 0.34 & 0.06 & 99.09 \\
\hline
\end{tabular}




\begin{tabular}{|c|c|c|c|c|c|c|c|c|c|c|c|c|c|c|}
\hline $\mathrm{Ba}$ & Ce & $\mathrm{Cr}$ & $\mathrm{Cu}$ & $\mathbf{G a}$ & La & $\mathbf{N b}$ & Nd & $\mathrm{Ni}$ & $\mathbf{R b}$ & Sr & $\mathbf{V}$ & $\mathbf{Y}$ & $\mathrm{Zn}$ & $\mathrm{Zr}$ \\
\hline \multicolumn{15}{|c|}{ Basalt of Sphinx Butte-Continued } \\
\hline na & na & na & na & na & na & na & na & na & na & na & na & na & na & na \\
\hline na & na & na & na & na & na & na & na & na & na & na & na & na & na & na \\
\hline \multicolumn{15}{|c|}{ Basalt southeast of Sparks Lake } \\
\hline 201 & 22 & 251 & 63 & 18 & 7 & 8 & 14 & 160 & 9 & 480 & 193 & 22 & 74 & 102 \\
\hline \multicolumn{15}{|c|}{ Basalt of Spruce Spring } \\
\hline na & na & na & na & na & na & na & na & na & na & na & na & na & na & na \\
\hline 306 & 34 & 162 & 58 & 13 & 12 & 11 & 20 & 122 & 8 & 496 & 203 & 23 & 67 & 151 \\
\hline 268 & 30 & 210 & 50 & 18 & 13 & 12 & 18 & 141 & 8 & 496 & 193 & 24 & 80 & 139 \\
\hline 265 & 30 & 214 & 52 & 18 & 16 & 11 & 19 & 143 & 8 & 497 & 194 & 24 & 79 & 141 \\
\hline \multicolumn{15}{|c|}{ Basalt and basaltic andesite of Talapus and Katsuk Buttes } \\
\hline 330 & 25 & 77 & 56 & 16 & 9 & 5 & $<10$ & 69 & 8 & 605 & 223 & 18 & 88 & 97 \\
\hline 267 & 28 & 286 & 54 & 16 & 11 & 8 & $<10$ & 115 & 9 & 497 & 188 & 22 & 72 & 127 \\
\hline 274 & 25 & 285 & 68 & 18 & 13 & 8 & 18 & 127 & 10 & 478 & 202 & 25 & 80 & 127 \\
\hline \multicolumn{15}{|c|}{ Basalt of lower Whychus Creek } \\
\hline 288 & 31 & 214 & 62 & 19 & 14 & 9 & 20 & 153 & 8 & 505 & 203 & 26 & 84 & 136 \\
\hline \multicolumn{15}{|c|}{ Basalt west of Millican Crater } \\
\hline 246 & 28 & 142 & 65 & 17 & 14 & 12 & 18 & 84 & 9 & 468 & 214 & 25 & 79 & 145 \\
\hline 225 & 27 & 310 & 70 & 16 & 12 & 11 & 19 & 190 & 9 & 445 & 197 & 23 & 82 & 133 \\
\hline 222 & 23 & 356 & 70 & 16 & 12 & 12 & 18 & 213 & 8 & 437 & 197 & 23 & 81 & 131 \\
\hline 246 & 25 & 238 & 75 & 17 & 10 & 10 & 15 & 145 & 7 & 454 & 210 & 24 & 82 & 136 \\
\hline 242 & 28 & 253 & 73 & 17 & 13 & 10 & 17 & 153 & 8 & 456 & 205 & 24 & 82 & 135 \\
\hline 242 & 33 & 147 & 72 & 18 & 15 & 14 & 20 & 91 & 8 & 481 & 203 & 27 & 79 & 142 \\
\hline 232 & 23 & 343 & 74 & 16 & 13 & 12 & 16 & 204 & 8 & 453 & 202 & 24 & 79 & 134 \\
\hline 218 & 25 & 425 & 71 & 17 & 11 & 14 & 18 & 266 & 8 & 441 & 198 & 25 & 82 & 130 \\
\hline \multicolumn{15}{|c|}{ Basalt of Whychus Creek } \\
\hline 266 & 19 & 267 & 58 & 13 & 8 & 8 & $<10$ & 129 & 8 & 476 & 184 & 21 & 65 & 120 \\
\hline 252 & 13 & 57 & 51 & 15 & 10 & 4 & $<10$ & 78 & 3 & 560 & 251 & 18 & 69 & 99 \\
\hline 237 & 16 & 85 & 77 & 18 & 9 & 5 & 13 & 97 & 6 & 553 & 198 & 22 & 85 & 104 \\
\hline \multicolumn{15}{|c|}{ Dacite of "Black Hump" } \\
\hline 593 & 38 & $<3$ & 3 & 24 & 17 & 12 & 30 & 3 & 25 & 363 & 33 & 41 & 90 & 250 \\
\hline 603 & 46 & $<5$ & 5 & 23 & 23 & 11 & 34 & 6 & 25 & 341 & 43 & 42 & 98 & 254 \\
\hline 586 & 43 & $<5$ & 6 & 22 & 17 & 11 & 24 & 6 & 27 & 351 & 41 & 44 & 96 & 255 \\
\hline 588 & 43 & $<5$ & $<2$ & 21 & 20 & 11 & 34 & 7 & 25 & 350 & 44 & 43 & 87 & 251 \\
\hline 635 & 47 & $<5$ & 2 & 17 & 16 & 10 & 43 & 3 & 26 & 343 & 29 & 35 & 85 & 254 \\
\hline 637 & 42 & $<5$ & 2 & 19 & 15 & 10 & 43 & 3 & 24 & 349 & 31 & 34 & 85 & 248 \\
\hline 642 & 47 & $<5$ & 2 & 17 & 21 & 10 & 38 & 3 & 25 & 354 & 17 & 34 & 89 & 249 \\
\hline 627 & 44 & $<5$ & 2 & 17 & 16 & 10 & 39 & 3 & 24 & 370 & 19 & 33 & 81 & 243 \\
\hline \multicolumn{15}{|c|}{ Dacite breccia of Lewis Glacier headwall } \\
\hline 627 & 35 & $<5$ & 17 & 15 & 9 & 8 & 31 & 3 & 36 & 396 & 103 & 24 & 65 & 208 \\
\hline 556 & 36 & 8 & 20 & 17 & 19 & 8 & 21 & 0 & 41 & 393 & 117 & 27 & 76 & 193 \\
\hline 557 & 33 & 7 & 17 & 20 & 20 & 8 & 21 & 1 & 42 & 396 & 118 & 27 & 80 & 195 \\
\hline \multicolumn{15}{|c|}{ Dacite southwest of Clark Glacier } \\
\hline 616 & 40 & $<3$ & 18 & 21 & 21 & 10 & 33 & 8 & 38 & 410 & 96 & 28 & 74 & 217 \\
\hline na & na & na & na & na & na & na & na & na & na & na & na & na & na & na \\
\hline na & na & na & na & na & na & na & na & na & na & na & na & na & na & na \\
\hline na & na & na & na & na & na & na & na & na & na & na & na & na & na & na \\
\hline na & na & na & na & na & na & na & na & na & na & na & na & na & na & na \\
\hline
\end{tabular}


Table 1. Chemical data for Three Sisters volcanic cluster.-Continued

\begin{tabular}{|c|c|c|c|c|c|c|c|c|c|c|c|c|c|c|}
\hline Sample & $\begin{array}{l}\text { Unit } \\
\text { label }\end{array}$ & $\begin{array}{c}\text { Volcanic } \\
\text { group }\end{array}$ & $\mathrm{SiO}_{2}$ & $\mathrm{TiO}_{2}$ & $\mathrm{Al}_{2} \mathrm{O}_{3}$ & $\mathrm{FeO} *$ & MnO & MgO & $\mathrm{CaO}$ & $\mathrm{Na}_{2} \mathrm{O}$ & $\mathrm{K}_{2} \mathrm{O}$ & $\mathbf{P}_{2} \mathbf{O}_{5}$ & LOI & $\begin{array}{c}\text { Original } \\
\text { total }\end{array}$ \\
\hline \multicolumn{15}{|c|}{ Dacite southwest of Clark Glacier-Continued } \\
\hline TS-139 & dcg & SS & 63.21 & 1.10 & 16.15 & 5.66 & 0.11 & 1.80 & 4.30 & 4.95 & 1.99 & 0.33 & -0.18 & 99.27 \\
\hline TS-140 & dcg & SS & 63.20 & 1.10 & 16.35 & 5.63 & 0.11 & 1.73 & 4.24 & 4.92 & 1.99 & 0.34 & 0.01 & 99.29 \\
\hline TS-142 & dcg & SS & 63.24 & 1.11 & 16.16 & 5.69 & 0.11 & 1.78 & 4.27 & 4.91 & 2.00 & 0.34 & 0.11 & 99.22 \\
\hline TS-143 & dcg & SS & 63.16 & 1.10 & 16.17 & 5.65 & 0.11 & 1.80 & 4.32 & 4.97 & 1.99 & 0.33 & 0.01 & 99.19 \\
\hline TS-145 & dcg & SS & 63.24 & 1.09 & 16.14 & 5.67 & 0.11 & 1.78 & 4.31 & 4.94 & 1.97 & 0.34 & 0.11 & 99.37 \\
\hline TS-146 & dcg & SS & 63.12 & 1.11 & 16.18 & 5.69 & 0.11 & 1.80 & 4.34 & 4.93 & 1.98 & 0.34 & 0.26 & 99.09 \\
\hline TS-154 & dcg & $\mathrm{SS}$ & 63.14 & 1.11 & 16.24 & 5.67 & 0.11 & 1.80 & 4.34 & 4.90 & 1.96 & 0.33 & -0.11 & 99.38 \\
\hline TS-155 & dcg & SS & 63.11 & 1.11 & 16.28 & 5.65 & 0.11 & 1.77 & 4.30 & 4.94 & 2.00 & 0.33 & -0.19 & 99.12 \\
\hline TS-158 & dcg & SS & 63.14 & 1.11 & 16.24 & 5.70 & 0.11 & 1.77 & 4.29 & 4.91 & 1.98 & 0.34 & -0.08 & 99.38 \\
\hline TS-530 & dcg & SS & 63.08 & 1.13 & 16.27 & 5.66 & 0.13 & 1.76 & 4.31 & 4.96 & 2.00 & 0.30 & 0.13 & 99.16 \\
\hline TS-531 & dcg & SS & 63.28 & 1.12 & 16.29 & 5.64 & 0.12 & 1.76 & 4.30 & 4.78 & 2.01 & 0.30 & 0.09 & 99.64 \\
\hline TS-532 & dcg & SS & 63.08 & 1.12 & 16.27 & 5.66 & 0.13 & 1.78 & 4.31 & 4.98 & 2.01 & 0.27 & 0.02 & 99.79 \\
\hline TS-533 & dcg & SS & 63.05 & 1.11 & 16.34 & 5.66 & 0.11 & 1.76 & 4.35 & 4.99 & 1.90 & 0.31 & 0.01 & 99.36 \\
\hline TS-534 & dcg & SS & 63.00 & 1.12 & 16.40 & 5.68 & 0.11 & 1.80 & 4.29 & 4.92 & 2.00 & 0.28 & $<0.01$ & 99.60 \\
\hline TS-535 & dcg & SS & 62.95 & 1.12 & 16.27 & 5.72 & 0.13 & 1.81 & 4.37 & 4.91 & 2.01 & 0.30 & 0.60 & 98.56 \\
\hline TS-538 & dcg & SS & 63.16 & 1.12 & 16.49 & 5.62 & 0.12 & 1.73 & 4.28 & 4.86 & 1.94 & 0.29 & 0.01 & 99.67 \\
\hline TS-539 & dcg & SS & 63.07 & 1.12 & 16.50 & 5.66 & 0.11 & 1.75 & 4.25 & 4.92 & 1.93 & 0.29 & $<0.01$ & 99.02 \\
\hline TS-540 & dcg & SS & 63.13 & 1.12 & 16.26 & 5.70 & 0.13 & 1.79 & 4.27 & 4.93 & 1.98 & 0.30 & 0.03 & 99.87 \\
\hline TS-541 & dcg & SS & 63.20 & 1.12 & 16.23 & 5.63 & 0.12 & 1.71 & 4.36 & 4.93 & 2.00 & 0.30 & 0.01 & 99.44 \\
\hline TS-543 & dcg & SS & 63.46 & 1.13 & 16.22 & 5.58 & 0.11 & 1.67 & 4.21 & 4.92 & 1.98 & 0.31 & $<0.01$ & 98.87 \\
\hline TS-544 & dcg & $\mathrm{SS}$ & 63.15 & 1.12 & 16.36 & 5.58 & 0.11 & 1.72 & 4.31 & 4.97 & 1.99 & 0.29 & $<0.01$ & 99.21 \\
\hline
\end{tabular}

\begin{tabular}{|c|c|c|c|c|c|c|c|c|c|c|c|c|c|c|}
\hline \multicolumn{15}{|c|}{ Dacite of Chambers Lakes } \\
\hline TS-6 & $\mathrm{dcl}$ & SS & 65.22 & 0.95 & 15.85 & 4.75 & 0.10 & 1.39 & 3.63 & 5.04 & 2.31 & 0.35 & 0.06 & 99.27 \\
\hline TS-7 & dcl & SS & 65.01 & 0.97 & 16.23 & 4.82 & 0.10 & 1.38 & 3.63 & 4.88 & 2.24 & 0.35 & 1.15 & 98.82 \\
\hline TS-19 & dcl & SS & 65.41 & 0.95 & 15.80 & 4.71 & 0.10 & 1.35 & 3.56 & 5.09 & 2.30 & 0.33 & 0.11 & 98.98 \\
\hline TS-20 & dcl & SS & 65.70 & 0.94 & 15.70 & 4.65 & 0.10 & 1.36 & 3.58 & 4.96 & 2.28 & 0.32 & 0.06 & 99.59 \\
\hline TS-21 & dcl & SS & 65.65 & 0.94 & 15.74 & 4.68 & 0.10 & 1.35 & 3.56 & 4.98 & 2.28 & 0.32 & 0.29 & 99.37 \\
\hline TS-170 & dcl & SS & 65.93 & 0.92 & 15.73 & 4.62 & 0.10 & 1.31 & 3.50 & 4.88 & 2.32 & 0.29 & 0.00 & 99.41 \\
\hline TS-171 & dcl & SS & 65.36 & 0.94 & 15.66 & 5.05 & 0.10 & 1.52 & 3.78 & 4.71 & 2.23 & 0.25 & -0.04 & 99.20 \\
\hline TS-208 & dcl & SS & 65.44 & 0.97 & 15.83 & 4.80 & 0.10 & 1.39 & 3.65 & 4.88 & 2.25 & 0.29 & 0.32 & 98.78 \\
\hline TS-211 & dcl & SS & 65.43 & 0.96 & 15.76 & 4.80 & 0.10 & 1.38 & 3.67 & 4.93 & 2.27 & 0.29 & 0.10 & 99.24 \\
\hline TS-212 & dcl & SS & 65.18 & 0.99 & 15.87 & 4.92 & 0.10 & 1.40 & 3.73 & 4.89 & 2.24 & 0.29 & 0.04 & 99.17 \\
\hline TS-213 & dcl & SS & 65.36 & 0.96 & 15.84 & 4.79 & 0.10 & 1.44 & 3.68 & 4.88 & 2.26 & 0.29 & -0.02 & 99.36 \\
\hline TS-214 & dcl & SS & 65.74 & 0.93 & 15.78 & 4.63 & 0.10 & 1.32 & 3.58 & 4.92 & 2.31 & 0.29 & 0.11 & 99.09 \\
\hline TS-239 & dcl & $\mathrm{SS}$ & 64.78 & 1.01 & 15.92 & 5.07 & 0.10 & 1.50 & 3.89 & 4.87 & 2.15 & 0.31 & 0.20 & 99.47 \\
\hline \multicolumn{15}{|c|}{ Dacite north of Carver Lake } \\
\hline TS-10 & dcn & SS & 66.89 & 0.70 & 15.65 & 3.98 & 0.08 & 1.45 & 3.63 & 4.54 & 2.45 & 0.24 & 0.35 & 99.92 \\
\hline TS-11 & den & SS & 67.39 & 0.64 & 15.57 & 3.78 & 0.08 & 1.43 & 3.54 & 4.44 & 2.50 & 0.23 & 0.21 & 99.76 \\
\hline TS-12 & dcn & $\mathrm{SS}$ & 67.12 & 0.67 & 15.56 & 3.94 & 0.08 & 1.49 & 3.60 & 4.46 & 2.46 & 0.23 & 0.36 & 99.87 \\
\hline \multicolumn{15}{|c|}{ Dacite of Dew Lake } \\
\hline TS-68 & ddl & $\mathrm{SS}$ & 64.10 & 1.06 & 16.00 & 5.34 & 0.12 & 1.48 & 3.82 & 5.21 & 2.08 & 0.39 & $<0.01$ & 99.60 \\
\hline TS-115 & ddl & $\mathrm{SS}$ & 64.26 & 1.04 & 16.09 & 5.30 & 0.11 & 1.43 & 3.69 & 5.19 & 2.11 & 0.38 & 0.08 & 99.04 \\
\hline TS-118 & ddl & $\mathrm{SS}$ & 64.43 & 1.04 & 15.98 & 5.26 & 0.11 & 1.46 & 3.80 & 5.08 & 2.10 & 0.35 & 0.14 & 99.09 \\
\hline TS-151 & ddl & SS & 64.12 & 1.07 & 15.88 & 5.39 & 0.12 & 1.56 & 3.86 & 5.18 & 2.06 & 0.37 & 0.07 & 99.11 \\
\hline \multicolumn{15}{|c|}{ Dacite ejecta of South Sister summit } \\
\hline TS-480 & des & $\mathrm{SS}$ & 62.87 & 0.98 & 16.22 & 5.80 & 0.11 & 2.43 & 5.02 & 3.69 & 2.19 & 0.27 & 1.86 & 98.22 \\
\hline TS-481A & des & SS & 62.82 & 0.98 & 16.13 & 5.80 & 0.11 & 2.40 & 4.97 & 3.24 & 2.88 & 0.27 & 1.75 & 98.78 \\
\hline TS-481B & des & SS & 62.76 & 0.98 & 16.32 & 5.72 & 0.11 & 2.31 & 4.92 & 3.51 & 2.72 & 0.26 & 1.36 & 98.86 \\
\hline TS-484 & des & SS & 63.86 & 0.96 & 15.99 & 5.60 & 0.11 & 2.15 & 4.60 & 3.97 & 2.08 & 0.27 & 1.79 & 98.41 \\
\hline TS-630B-1 & des & SS & 64.08 & 0.97 & 16.44 & 5.43 & 0.09 & 1.72 & 4.27 & 4.15 & 2.26 & 0.19 & na & 96.25 \\
\hline
\end{tabular}




\begin{tabular}{|c|c|c|c|c|c|c|c|c|c|c|c|c|c|c|}
\hline $\mathbf{B a}$ & Ce & $\mathrm{Cr}$ & Cu & Ga & La & Nb & Nd & $\mathbf{N i}$ & $\mathbf{R b}$ & $\mathrm{Sr}$ & $\mathbf{V}$ & $\mathbf{Y}$ & Zn & $\mathrm{Zr}$ \\
\hline \multicolumn{15}{|c|}{ Dacite southwest of Clark Glacier-Continued } \\
\hline na & na & na & na & na & na & na & na & na & na & na & na & na & na & na \\
\hline na & na & na & na & na & na & na & na & na & na & na & na & na & na & na \\
\hline na & na & na & na & na & na & na & na & na & na & na & na & na & na & na \\
\hline na & na & na & na & na & na & na & na & na & na & na & na & na & na & na \\
\hline na & na & na & na & na & na & na & na & na & na & na & na & na & na & na \\
\hline na & na & na & na & na & na & na & na & na & na & na & na & na & na & na \\
\hline na & na & na & na & na & na & na & na & na & na & na & na & na & na & na \\
\hline 682 & 39 & $<5$ & 14 & 14 & 18 & 9 & 34 & 3 & 36 & 405 & 87 & 25 & 59 & 214 \\
\hline 673 & 42 & $<5$ & 12 & 15 & 14 & 9 & 35 & 4 & 35 & 398 & 85 & 24 & 64 & 213 \\
\hline 668 & 40 & $<5$ & 15 & 13 & 13 & 9 & 31 & 3 & 39 & 402 & 101 & 26 & 62 & 217 \\
\hline 690 & 43 & $<5$ & 13 & 15 & 20 & 9 & 30 & 3 & 36 & 395 & 90 & 26 & 58 & 215 \\
\hline 688 & 42 & $<5$ & 14 & 14 & 19 & 9 & 23 & 3 & 37 & 403 & 98 & 26 & 64 & 215 \\
\hline 679 & 45 & $<5$ & 16 & 14 & 19 & 9 & 26 & 3 & 37 & 398 & 95 & 24 & 64 & 213 \\
\hline 679 & 43 & $<5$ & 15 & 16 & 18 & 9 & 27 & 3 & 37 & 386 & 95 & 24 & 60 & 214 \\
\hline 689 & 42 & $<5$ & 11 & 14 & 19 & 9 & 27 & 3 & 37 & 395 & 88 & 26 & 57 & 215 \\
\hline
\end{tabular}

\begin{tabular}{|c|c|c|c|c|c|c|c|c|c|c|c|c|c|c|}
\hline \multicolumn{15}{|c|}{ Dacite of Chambers Lakes } \\
\hline 671 & 43 & $<3$ & 19 & 20 & 22 & 11 & 22 & 8 & 43 & 337 & 71 & 26 & 72 & 237 \\
\hline 678 & 40 & 4 & 11 & 20 & 21 & 11 & 22 & 5 & 46 & 335 & 70 & 25 & 64 & 236 \\
\hline 680 & 40 & 4 & 12 & 19 & 21 & 11 & 23 & 4 & 45 & 332 & 68 & 26 & 73 & 234 \\
\hline 692 & 41 & $<5$ & 22 & 17 & 19 & 11 & 23 & 6 & 46 & 332 & 78 & 27 & 65 & 234 \\
\hline 668 & 40 & $<5$ & 19 & 20 & 19 & 12 & 26 & 6 & 46 & 352 & 79 & 27 & 73 & 242 \\
\hline 674 & 40 & $<5$ & 12 & 21 & 19 & 12 & 20 & 3 & 45 & 341 & 84 & 27 & 67 & 237 \\
\hline 672 & 39 & $<5$ & 18 & 19 & 18 & 11 & 20 & 6 & 43 & 349 & 72 & 26 & 65 & 234 \\
\hline 680 & 42 & $<5$ & 16 & 20 & 24 & 11 & 25 & 3 & 43 & 342 & 75 & 26 & 65 & 233 \\
\hline 678 & 41 & $<5$ & 17 & 18 & 21 & 11 & 29 & 6 & 46 & 340 & 73 & 27 & 68 & 237 \\
\hline 655 & 43 & $<5$ & 18 & 19 & 23 & 11 & 25 & 6 & 42 & 358 & 85 & 27 & 70 & 232 \\
\hline 698 & 41 & 14 & 30 & 19 & 25 & 9 & 29 & 14 & 55 & 308 & 65 & 18 & 51 & 205 \\
\hline \multicolumn{15}{|c|}{ Dacite of Dew Lake } \\
\hline 629 & 41 & 4 & 8 & 22 & 21 & 13 & 24 & 4 & 39 & 371 & 62 & 31 & 82 & 246 \\
\hline na & na & na & na & na & na & na & na & na & na & na & na & na & na & na \\
\hline na & na & na & na & na & na & na & na & na & na & na & na & na & na & na \\
\hline na & na & na & na & na & na & na & na & na & na & na & na & na & na & na \\
\hline
\end{tabular}

Dacite ejecta of South Sister summit

\begin{tabular}{rrrrrrrrrrrrrrr}
\hline 616 & 34 & $<5$ & 44 & 14 & 11 & 6 & $<10$ & 3 & 43 & 388 & 124 & 21 & 59 & 187 \\
964 & 32 & $<5$ & 51 & 14 & 13 & 7 & $<10$ & 3 & 44 & 379 & 118 & 22 & 60 & 187 \\
845 & 33 & 6 & 45 & 16 & 13 & 7 & 12 & 3 & 42 & 383 & 126 & 22 & 60 & 189 \\
642 & 36 & $<5$ & 19 & 15 & 13 & 8 & $<10$ & 3 & 38 & 368 & 109 & 22 & 56 & 201 \\
573 & 34 & 13 & 11 & 19 & 16 & 8 & 19 & 3 & 44 & 375 & 121 & 24 & 59 & 188
\end{tabular}


Table 1. Chemical data for Three Sisters volcanic cluster--Continued

\begin{tabular}{|c|c|c|c|c|c|c|c|c|c|c|c|c|c|c|}
\hline Sample & $\begin{array}{l}\text { Unit } \\
\text { label }\end{array}$ & $\begin{array}{c}\text { Volcanic } \\
\text { group }\end{array}$ & $\mathrm{SiO}_{2}$ & $\mathrm{TiO}_{2}$ & $\mathrm{Al}_{2} \mathrm{O}_{3}$ & $\mathrm{Fe} 0 *$ & $\mathrm{MnO}$ & MgO & $\mathrm{CaO}$ & $\mathrm{Na}_{2} \mathrm{O}$ & $\mathrm{K}_{2} \mathbf{O}$ & $\mathrm{P}_{2} \mathrm{O}_{5}$ & LOI & $\begin{array}{c}\text { Original } \\
\text { total }\end{array}$ \\
\hline \multicolumn{15}{|c|}{ Dacite ejecta of South Sister summit—Continued } \\
\hline TS-630B-2 & des & SS & 64.20 & 0.98 & 16.20 & 5.57 & 0.09 & 1.75 & 4.26 & 4.05 & 2.31 & 0.20 & na & 97.56 \\
\hline TS-632A & des & SS & 63.98 & 0.96 & 15.69 & 5.48 & 0.16 & 2.13 & 4.52 & 4.28 & 2.19 & 0.22 & na & 96.66 \\
\hline TS-632B & des & SS & 63.47 & 0.94 & 16.12 & 5.40 & 0.10 & 2.08 & 4.61 & 4.46 & 2.19 & 0.21 & na & 97.71 \\
\hline TS-632C & des & SS & 63.12 & 1.00 & 16.14 & 5.62 & 0.11 & 2.20 & 4.69 & 4.35 & 2.15 & 0.22 & na & 96.14 \\
\hline TS-695 & $\begin{array}{l}\text { des } \\
\text { [lithic] }\end{array}$ & SS & 63.84 & 1.10 & 16.26 & 5.05 & 0.07 & 1.66 & 4.19 & 5.02 & 2.10 & 0.31 & na & 98.72 \\
\hline TS-696A & des & SS & 63.52 & 1.10 & 16.16 & 5.51 & 0.12 & 1.80 & 4.40 & 4.55 & 2.14 & 0.30 & na & 96.86 \\
\hline TS-696B & des & SS & 63.73 & 1.10 & 16.26 & 5.48 & 0.12 & 1.99 & 4.42 & 4.04 & 2.17 & 0.30 & na & 95.85 \\
\hline TS-696D & des & SS & 63.41 & 1.07 & 16.47 & 5.55 & 0.12 & 2.03 & 4.48 & 3.99 & 2.17 & 0.30 & na & 95.55 \\
\hline TS-696DR & des & $\mathrm{SS}$ & 63.41 & 1.08 & 16.42 & 5.56 & 0.12 & 2.08 & 4.48 & 3.99 & 2.17 & 0.30 & na & 95.79 \\
\hline \multicolumn{15}{|c|}{ Dacite of Goose Creek } \\
\hline TS-92 & dgc & SS & 64.81 & 0.99 & 16.03 & 4.94 & 0.10 & 1.46 & 3.84 & 4.88 & 2.19 & 0.36 & 0.02 & 100.04 \\
\hline TS-323 & dgc & $\mathrm{SS}$ & 65.13 & 0.99 & 15.94 & 4.76 & 0.10 & 1.43 & 3.78 & 4.95 & 2.23 & 0.28 & na & 99.68 \\
\hline TS-336 & dgc & SS & 65.28 & 0.99 & 15.84 & 4.86 & 0.10 & 1.34 & 3.76 & 4.83 & 2.24 & 0.35 & $<0.01$ & 99.33 \\
\hline TS-340 & $\mathrm{dgc}$ & SS & 65.15 & 0.99 & 15.73 & 4.89 & 0.10 & 1.45 & 3.83 & 4.86 & 2.24 & 0.35 & 0.32 & 98.76 \\
\hline TS-706 & dgc & $\mathrm{SS}$ & 65.17 & 0.96 & 16.09 & 4.72 & 0.10 & 1.35 & 3.66 & 5.01 & 2.27 & 0.27 & na & 99.25 \\
\hline \multicolumn{15}{|c|}{ Dacite of Green Lakes } \\
\hline TS-508 & dgl & $\mathrm{SS}$ & 64.17 & 1.10 & 15.89 & 5.63 & 0.11 & 1.67 & 4.17 & 4.42 & 2.08 & 0.36 & 0.50 & 99.65 \\
\hline TS-509 & $\mathrm{dgl}$ & SS & 64.19 & 1.09 & 15.77 & 5.65 & 0.11 & 1.65 & 4.17 & 4.55 & 2.07 & 0.34 & $<0.01$ & 99.15 \\
\hline TS-519 & $\mathrm{dgl}$ & SS & 64.22 & 1.07 & 15.83 & 5.60 & 0.11 & 1.63 & 4.25 & 4.51 & 2.04 & 0.34 & $<0.01$ & 99.42 \\
\hline TS-520 & dgl & SS & 64.20 & 1.09 & 15.77 & 5.63 & 0.11 & 1.67 & 4.26 & 4.51 & 2.03 & 0.34 & $<0.01$ & 99.14 \\
\hline TS-578 & $\mathrm{dgl}$ & SS & 62.85 & 1.11 & 16.13 & 5.92 & 0.12 & 1.87 & 4.49 & 4.91 & 1.86 & 0.34 & $<0.01$ & 100.00 \\
\hline TS-579 & $\mathrm{dgl}$ & $\mathrm{SS}$ & 63.56 & 1.01 & 15.99 & 5.60 & 0.11 & 1.89 & 4.30 & 4.87 & 1.97 & 0.31 & $<0.01$ & 100.29 \\
\hline \multicolumn{15}{|c|}{ Dacite of Hayden Glacier-Renfrew Glacier col } \\
\hline TS-410 & dhr & MS & 64.05 & 0.95 & 16.19 & 5.42 & 0.15 & 1.32 & 3.55 & 5.86 & 1.75 & 0.35 & na & 99.31 \\
\hline TS-411 & dhr & MS & 64.31 & 0.93 & 16.35 & 5.60 & 0.14 & 1.27 & 3.45 & 5.49 & 1.67 & 0.39 & $<0.01$ & 99.28 \\
\hline TS-412 & dhr & MS & 63.58 & 1.01 & 15.94 & 5.91 & 0.14 & 1.51 & 3.71 & 5.71 & 1.66 & 0.42 & $<0.01$ & 99.33 \\
\hline \multicolumn{15}{|c|}{ Dacite of Irving Glacier } \\
\hline TS-5 & dig & MS & 64.23 & 0.92 & 16.16 & 5.53 & 0.14 & 1.26 & 3.33 & 5.90 & 1.73 & 0.39 & $<0.01$ & 99.24 \\
\hline TS-5A & dig & MS & 64.11 & 0.92 & 16.23 & 5.56 & 0.14 & 1.27 & 3.31 & 5.92 & 1.73 & 0.41 & 0.05 & 100.05 \\
\hline TS-238 & dig & MS & 64.21 & 0.91 & 16.23 & 5.50 & 0.14 & 1.27 & 3.42 & 5.85 & 1.70 & 0.37 & 0.22 & 99.43 \\
\hline \multicolumn{15}{|c|}{ Dacite of Kokostick Butte } \\
\hline TS-63 & $\mathrm{dkb}$ & SS & 63.05 & 0.99 & 16.29 & 5.57 & 0.11 & 2.03 & 4.62 & 4.77 & 1.91 & 0.27 & 0.10 & 99.04 \\
\hline TS-246 & $\mathrm{dkb}$ & SS & 62.54 & 1.02 & 16.46 & 5.83 & 0.11 & 2.07 & 4.85 & 4.63 & 1.84 & 0.26 & 0.01 & 99.22 \\
\hline TS-348 & $d k b$ & SS & 62.45 & 1.04 & 16.37 & 5.79 & 0.11 & 2.05 & 5.01 & 4.64 & 1.84 & 0.30 & 0.96 & 98.57 \\
\hline TS-349 & $\mathrm{dkb}$ & SS & 62.80 & 1.04 & 16.30 & 5.70 & 0.11 & 1.97 & 4.67 & 4.81 & 1.91 & 0.28 & 0.08 & 98.96 \\
\hline TS-563 & $\mathrm{dkb}$ & SS & 62.49 & 1.05 & 16.41 & 5.76 & 0.12 & 2.07 & 4.81 & 4.69 & 1.94 & 0.25 & 0.97 & 98.34 \\
\hline \multicolumn{15}{|c|}{ Dacite of Linton Creek } \\
\hline TS-268 & dlc & MS & 66.82 & 0.81 & 15.54 & 4.37 & 0.09 & 1.32 & 3.38 & 4.73 & 2.32 & 0.21 & 0.55 & 98.68 \\
\hline \multicolumn{15}{|c|}{ Dacite of Lewis Glacier headwall } \\
\hline TS-14 & dlg & $\mathrm{SS}$ & 64.35 & 1.01 & 15.79 & 5.33 & 0.10 & 1.65 & 4.09 & 4.86 & 2.12 & 0.32 & $<0.01$ & 99.68 \\
\hline TS-43 & dlg & SS & 63.58 & 1.09 & 16.07 & 5.53 & 0.11 & 1.70 & 4.22 & 4.94 & 2.00 & 0.35 & 0.77 & 98.53 \\
\hline TS-205 & dlg & SS & 63.65 & 1.10 & 15.91 & 5.68 & 0.11 & 1.70 & 4.24 & 4.85 & 2.04 & 0.31 & -0.14 & 98.90 \\
\hline TS-581 & dlg & SS & 63.55 & 1.09 & 16.11 & 5.52 & 0.11 & 1.70 & 4.25 & 4.85 & 2.03 & 0.38 & 0.44 & 99.53 \\
\hline TS-631 & dlg & SS & 63.75 & 1.09 & 16.00 & 5.46 & 0.11 & 1.64 & 4.23 & 4.97 & 2.03 & 0.30 & na & 99.38 \\
\hline TS-692 & dlg & SS & 63.67 & 1.09 & 16.10 & 5.35 & 0.11 & 1.68 & 4.24 & 5.02 & 2.04 & 0.30 & na & 98.63 \\
\hline TS-693 & dlg & $\mathrm{SS}$ & 63.82 & 1.09 & 16.12 & 5.13 & 0.11 & 1.69 & 4.22 & 5.08 & 2.04 & 0.31 & na & 99.58 \\
\hline TS-694 & dlg & SS & 63.61 & 1.09 & 16.06 & 5.38 & 0.12 & 1.73 & 4.22 & 5.04 & 2.03 & 0.30 & na & 98.86 \\
\hline
\end{tabular}




\begin{tabular}{|c|c|c|c|c|c|c|c|c|c|c|c|c|c|c|}
\hline $\mathrm{Ba}$ & Ce & $\mathrm{Cr}$ & $\mathrm{Cu}$ & $\mathbf{G a}$ & La & $\mathbf{N b}$ & Nd & $\mathrm{Ni}$ & $\mathbf{R b}$ & Sr & $\mathbf{V}$ & $\mathbf{Y}$ & $\mathrm{Zn}$ & $\mathrm{Zr}$ \\
\hline \multicolumn{15}{|c|}{ Dacite ejecta of South Sister summit-Continued } \\
\hline 586 & 35 & 14 & 12 & 20 & 19 & 8 & 19 & 4 & 45 & 369 & 126 & 26 & 61 & 194 \\
\hline 678 & 34 & 12 & 36 & 17 & 16 & 8 & 21 & 5 & 40 & 359 & 121 & 24 & 66 & 181 \\
\hline 572 & 38 & 12 & 27 & 17 & 20 & 7 & 20 & 4 & 41 & 378 & 117 & 24 & 63 & 187 \\
\hline 560 & 38 & 12 & 26 & 18 & 19 & 7 & 17 & 6 & 40 & 371 & 129 & 24 & 69 & 182 \\
\hline 613 & 44 & 1 & 18 & 19 & 20 & 9 & 25 & 0 & 38 & 394 & 96 & 28 & 80 & 212 \\
\hline 594 & 41 & 1 & 18 & 18 & 23 & 10 & 22 & 0 & 38 & 392 & 93 & 26 & 77 & 206 \\
\hline 585 & 35 & 1 & 20 & 19 & 21 & 8 & 19 & 0 & 37 & 393 & 96 & 28 & 79 & 203 \\
\hline 572 & 40 & 3 & 17 & 18 & 20 & 9 & 24 & 2 & 36 & 395 & 95 & 28 & 75 & 200 \\
\hline 574 & 42 & 3 & 17 & 19 & 21 & 10 & 24 & 3 & 35 & 398 & 91 & 27 & 76 & 201 \\
\hline \multicolumn{15}{|c|}{ Dacite of Goose Creek } \\
\hline 659 & 41 & $<3$ & 22 & 20 & 19 & 11 & 30 & 9 & 44 & 363 & 75 & 27 & 69 & 235 \\
\hline 661 & 42 & 4 & 15 & 19 & 17 & 9 & 23 & 0 & 43 & 357 & 80 & 26 & 66 & 220 \\
\hline 722 & 40 & $<5$ & 14 & 15 & 16 & 9 & 25 & 3 & 42 & 348 & 76 & 23 & 53 & 232 \\
\hline 706 & 38 & $<5$ & 14 & 13 & 13 & 9 & 37 & 3 & 41 & 346 & 76 & 24 & 60 & 232 \\
\hline 659 & 44 & 2 & 12 & 19 & 21 & 9 & 22 & 1 & 43 & 344 & 76 & 27 & 65 & 221 \\
\hline \multicolumn{15}{|c|}{ Dacite of Green Lakes } \\
\hline 668 & 41 & $<5$ & 24 & 15 & 15 & 9 & 25 & 3 & 39 & 360 & 93 & 24 & 63 & 224 \\
\hline na & na & na & na & na & na & na & na & na & na & na & na & na & na & na \\
\hline na & na & na & na & na & na & na & na & na & na & na & na & na & na & na \\
\hline na & na & na & na & na & na & na & na & na & na & na & na & na & na & na \\
\hline 624 & 36 & $<5$ & 14 & 16 & 14 & 8 & 28 & 3 & 34 & 403 & 115 & 23 & 63 & 205 \\
\hline 654 & 37 & $<5$ & 5 & 15 & 14 & 8 & 13 & 2 & 35 & 375 & 95 & 22 & 54 & 206 \\
\hline \multicolumn{15}{|c|}{ Dacite of Hayden Glacier-Renfrew Glacier col } \\
\hline 570 & 47 & 2 & 5 & 22 & 18 & 10 & 28 & 0 & 26 & 360 & 27 & 39 & 101 & 235 \\
\hline 642 & 47 & $<5$ & 2 & 17 & 15 & 9 & 35 & 3 & 23 & 352 & 25 & 34 & 84 & 249 \\
\hline 563 & 38 & na & 8 & 26 & 18 & 14 & 33 & na & 25 & 386 & 77 & 50 & 94 & 302 \\
\hline \multicolumn{15}{|c|}{ Dacite of Irving Glacier } \\
\hline 598 & 46 & $<3$ & 5 & 24 & 22 & 12 & 28 & 5 & 24 & 341 & 33 & 41 & 96 & 254 \\
\hline 595 & 41 & $<3$ & 4 & 25 & 18 & 11 & 28 & 10 & 25 & 336 & 36 & 42 & 98 & 254 \\
\hline 588 & 44 & $<5$ & 7 & 22 & 20 & 12 & 32 & 5 & 24 & 348 & 32 & 42 & 95 & 256 \\
\hline \multicolumn{15}{|c|}{ Dacite of Kokostick Butte } \\
\hline 573 & 36 & 6 & 12 & 18 & 19 & 10 & 15 & 3 & 36 & 404 & 107 & 21 & 64 & 191 \\
\hline 560 & 32 & 11 & 16 & 23 & 18 & 9 & 18 & 12 & 35 & 425 & 113 & 23 & 66 & 190 \\
\hline 584 & 37 & $<5$ & 23 & 15 & 13 & 9 & 28 & 3 & 34 & 432 & 136 & 22 & 57 & 187 \\
\hline 576 & 34 & 5 & 15 & 23 & 18 & 12 & 16 & na & 37 & 441 & 141 & 37 & 66 & 247 \\
\hline 613 & 35 & $<5$ & 6 & 14 & 13 & 8 & 29 & 3 & 34 & 413 & 120 & 21 & 54 & 186 \\
\hline \multicolumn{15}{|c|}{ Dacite of Linton Creek } \\
\hline 697 & 34 & $<5$ & 10 & 20 & 19 & 8 & 16 & 8 & 46 & 332 & 72 & 20 & 62 & 217 \\
\hline \multicolumn{15}{|c|}{ Dacite of Lewis Glacier headwall } \\
\hline 628 & 37 & 5 & 22 & 19 & 20 & 10 & 23 & 3 & 40 & 355 & 93 & 24 & 68 & 216 \\
\hline 618 & 39 & $<3$ & 20 & 20 & 20 & 11 & 24 & 4 & 39 & 392 & 95 & 27 & 78 & 227 \\
\hline 614 & 36 & $<5$ & 21 & 23 & 17 & 11 & 24 & 6 & 39 & 369 & 91 & 27 & 71 & 226 \\
\hline 685 & 38 & $<5$ & 10 & 14 & 16 & 9 & 33 & 3 & 37 & 385 & 99 & 26 & 62 & 218 \\
\hline 603 & 43 & 1 & 20 & 18 & 18 & 9 & 23 & 0 & 39 & 398 & 94 & 27 & 74 & 211 \\
\hline 606 & 44 & 1 & 20 & 19 & 20 & 10 & 22 & 0 & 39 & 390 & 94 & 28 & 77 & 209 \\
\hline 609 & 45 & 2 & 19 & 19 & 21 & 9 & 25 & 0 & 38 & 389 & 92 & 28 & 77 & 211 \\
\hline 603 & 42 & 1 & 20 & 20 & 21 & 10 & 22 & 0 & 38 & 390 & 94 & 27 & 78 & 211 \\
\hline
\end{tabular}


Table 1. Chemical data for Three Sisters volcanic cluster--Continued

\begin{tabular}{|c|c|c|c|c|c|c|c|c|c|c|c|c|c|c|}
\hline Sample & $\begin{array}{l}\text { Unit } \\
\text { label }\end{array}$ & $\begin{array}{c}\text { Volcanic } \\
\text { group }\end{array}$ & $\mathrm{SiO}_{2}$ & $\mathrm{TiO}_{2}$ & $\mathrm{Al}_{2} \mathrm{O}_{3}$ & $\mathrm{FeO} *$ & MnO & MgO & $\mathrm{CaO}$ & $\mathrm{Na}_{2} \mathrm{O}$ & $\mathrm{K}_{2} \mathbf{O}$ & $\mathbf{P}_{2} \mathbf{O}_{5}$ & LOI & $\begin{array}{c}\text { Original } \\
\text { total }\end{array}$ \\
\hline \multicolumn{15}{|c|}{ Dacite of Lewis Glacier headwall_-Continued } \\
\hline TS-697 & dlg & $\mathrm{SS}$ & 63.73 & 1.09 & 16.08 & 5.37 & 0.11 & 1.68 & 4.24 & 4.93 & 2.06 & 0.31 & na & 98.66 \\
\hline \multicolumn{15}{|c|}{ Dacite of Lane Plateau } \\
\hline TS-103 & dlp & MS & 65.31 & 0.73 & 16.18 & 5.22 & 0.14 & 0.97 & 2.85 & 6.07 & 1.83 & 0.30 & $<0.01$ & 99.13 \\
\hline TS-287 & dlp & MS & 64.22 & 0.92 & 16.18 & 5.51 & 0.14 & 1.25 & 3.36 & 5.93 & 1.73 & 0.37 & -0.08 & 99.11 \\
\hline TS-308 & dlp & MS & 64.21 & 0.91 & 16.20 & 5.48 & 0.14 & 1.27 & 3.40 & 5.92 & 1.71 & 0.35 & 0.09 & 99.58 \\
\hline TS-419 & dlp & MS & 64.35 & 0.91 & 16.04 & 5.48 & 0.14 & 1.25 & 3.35 & 5.95 & 1.76 & 0.37 & $<0.01$ & 98.74 \\
\hline \multicolumn{15}{|c|}{ Dacite of Mesa Creek } \\
\hline TS-111 & $\mathrm{dmc}$ & $\mathrm{P}$ & 65.08 & 0.87 & 16.52 & 4.74 & 0.10 & 1.37 & 3.82 & 5.00 & 1.87 & 0.23 & 0.36 & 98.87 \\
\hline \multicolumn{15}{|c|}{ Dacite southeast of Moraine Lake } \\
\hline TS-337 & $\mathrm{dml}$ & $\mathrm{SS}$ & 64.43 & 0.99 & 16.01 & 5.07 & 0.11 & 1.57 & 4.11 & 4.92 & 2.05 & 0.33 & 0.22 & 99.55 \\
\hline TS-353 & $\mathrm{dml}$ & SS & 64.64 & 1.00 & 15.88 & 5.05 & 0.10 & 1.51 & 3.96 & 4.93 & 2.19 & 0.34 & 0.44 & 98.47 \\
\hline TS-354 & $\mathrm{dml}$ & $\mathrm{SS}$ & 65.02 & 1.01 & 15.76 & 4.96 & 0.10 & 1.44 & 3.89 & 4.88 & 2.20 & 0.35 & 0.27 & 99.87 \\
\hline TS-355 & $\mathrm{dml}$ & $\mathrm{SS}$ & 65.17 & 0.99 & 15.77 & 4.88 & 0.10 & 1.42 & 3.85 & 4.86 & 2.22 & 0.35 & 0.24 & 99.80 \\
\hline TS-357 & $\mathrm{dml}$ & SS & 64.43 & 1.00 & 16.13 & 5.10 & 0.11 & 1.55 & 4.03 & 4.85 & 2.05 & 0.34 & 0.15 & 100.02 \\
\hline TS-359 & $\mathrm{dml}$ & SS & 64.39 & 1.00 & 16.05 & 5.09 & 0.11 & 1.58 & 4.11 & 4.89 & 2.05 & 0.32 & 0.21 & 99.30 \\
\hline TS-361 & $\mathrm{dml}$ & SS & 65.14 & 1.01 & 15.79 & 5.00 & 0.10 & 1.41 & 3.75 & 4.83 & 2.22 & 0.36 & $<0.01$ & 99.69 \\
\hline TS-362 & $\mathrm{dml}$ & SS & 65.72 & 0.95 & 15.68 & 4.72 & 0.10 & 1.34 & 3.63 & 4.84 & 2.29 & 0.33 & 0.24 & 99.72 \\
\hline TS-440 & $\mathrm{dml}$ & SS & 64.30 & 1.00 & 16.38 & 5.07 & 0.11 & 1.58 & 4.12 & 4.68 & 2.04 & 0.32 & 0.31 & 99.13 \\
\hline TS-441 & $\mathrm{dml}$ & SS & 64.57 & 1.00 & 16.30 & 5.07 & 0.11 & 1.54 & 3.94 & 4.67 & 2.10 & 0.31 & 0.63 & 98.41 \\
\hline TS-442 & $\mathrm{dml}$ & SS & 64.27 & 1.01 & 16.34 & 5.10 & 0.11 & 1.58 & 4.11 & 4.69 & 2.03 & 0.34 & 0.31 & 99.33 \\
\hline TS-704 & $\mathrm{dml}$ & SS & 64.05 & 0.99 & 16.44 & 5.04 & 0.11 & 1.54 & 4.06 & 5.06 & 2.06 & 0.26 & na & 99.34 \\
\hline TS-705 & $\mathrm{dml}$ & SS & 64.01 & 1.00 & 16.59 & 5.07 & 0.11 & 1.48 & 3.97 & 5.04 & 2.07 & 0.26 & na & 99.66 \\
\hline
\end{tabular}

\begin{tabular}{|c|c|c|c|c|c|c|c|c|c|c|c|c|c|c|}
\hline \multicolumn{15}{|c|}{ Dacite north of Moraine Lake } \\
\hline TS-161 & $\mathrm{dmn}$ & SS & 65.14 & 0.93 & 15.98 & 4.79 & 0.10 & 1.44 & 3.78 & 5.02 & 2.13 & 0.28 & -0.06 & 99.07 \\
\hline TS-363 & $\mathrm{dmn}$ & SS & 65.37 & 0.96 & 15.79 & 4.83 & 0.10 & 1.40 & 3.67 & 4.91 & 2.26 & 0.32 & 0.13 & 99.04 \\
\hline TS-363 & $\mathrm{dmn}$ & SS & 65.38 & 0.97 & 15.79 & 4.82 & 0.10 & 1.41 & 3.68 & 4.88 & 2.26 & 0.31 & 0.14 & 99.02 \\
\hline TS-478 & $\mathrm{dmn}$ & SS & 66.25 & 0.94 & 15.74 & 4.62 & 0.10 & 1.33 & 3.57 & 4.44 & 2.30 & 0.32 & $<0.01$ & 99.98 \\
\hline TS-488 & dmn & SS & 66.32 & 0.92 & 15.66 & 4.60 & 0.10 & 1.32 & 3.57 & 4.47 & 2.33 & 0.32 & 0.14 & 99.88 \\
\hline TS-491 & $\mathrm{dmn}$ & SS & 66.14 & 0.93 & 15.88 & 4.61 & 0.10 & 1.29 & 3.57 & 4.43 & 2.33 & 0.33 & 0.06 & 99.70 \\
\hline TS-492 & $\mathrm{dmn}$ & SS & 65.67 & 0.92 & 16.04 & 4.75 & 0.10 & 1.47 & 3.76 & 4.45 & 2.15 & 0.29 & 0.09 & 99.95 \\
\hline TS-495 & $\mathrm{dmn}$ & SS & 65.76 & 0.96 & 15.89 & 4.78 & 0.10 & 1.36 & 3.71 & 4.44 & 2.27 & 0.34 & $<0.01$ & 99.66 \\
\hline TS-496 & $\mathrm{dmn}$ & SS & 66.13 & 0.87 & 15.93 & 4.53 & 0.10 & 1.38 & 3.71 & 4.48 & 2.18 & 0.28 & 0.27 & 99.40 \\
\hline TS-588 & $\mathrm{dmn}$ & SS & 66.06 & 0.86 & 15.54 & 4.64 & 0.09 & 1.50 & 3.63 & 4.69 & 2.31 & 0.29 & 0.22 & 99.37 \\
\hline \multicolumn{15}{|c|}{ Dacite of Middle Sister summit } \\
\hline TS-233 & $\mathrm{dms}$ & MS & 66.73 & 0.77 & 15.39 & 4.27 & 0.08 & 1.48 & 3.43 & 4.28 & 2.94 & 0.22 & 1.04 & 98.36 \\
\hline TS-236 & $\mathrm{dms}$ & MS & 65.92 & 0.84 & 15.42 & 4.57 & 0.08 & 1.64 & 3.64 & 4.39 & 2.85 & 0.24 & 0.78 & 98.81 \\
\hline TS-237A & $\mathrm{dms}$ & MS & 63.88 & 0.99 & 15.95 & 5.31 & 0.09 & 1.93 & 4.24 & 4.40 & 2.52 & 0.29 & 0.34 & 99.31 \\
\hline TS-237B & $\mathrm{dms}$ & MS & 65.70 & 0.83 & 15.77 & 4.57 & 0.08 & 1.63 & 3.64 & 4.35 & 2.78 & 0.24 & 0.61 & 99.14 \\
\hline \multicolumn{15}{|c|}{ Dacite coulee west of Moraine Lake } \\
\hline TS-72 & dmw & $\mathrm{SS}$ & 64.63 & 0.97 & 16.16 & 4.96 & 0.11 & 1.52 & 3.85 & 5.01 & 2.07 & 0.33 & 0.09 & 99.87 \\
\hline TS-162 & dmw & SS & 65.45 & 0.90 & 16.01 & 4.84 & 0.10 & 1.44 & 3.58 & 4.85 & 2.17 & 0.25 & 0.30 & 98.92 \\
\hline TS-163 & dmw & SS & 64.92 & 0.96 & 15.98 & 4.91 & 0.11 & 1.53 & 3.87 & 4.94 & 2.10 & 0.28 & 0.19 & 99.12 \\
\hline TS-356 & dmw & SS & 65.11 & 0.95 & 15.93 & 4.87 & 0.11 & 1.46 & 3.81 & 4.91 & 2.12 & 0.33 & $<0.01$ & 99.44 \\
\hline \multicolumn{15}{|c|}{ Dacite north of Teardrop Pool } \\
\hline TS-629A & dnt & $\mathrm{SS}$ & 63.10 & 0.95 & 16.11 & 5.55 & 0.11 & 2.20 & 4.61 & 4.75 & 2.00 & 0.21 & na & 98.00 \\
\hline TS-629B & dnt & SS & 62.74 & 0.96 & 16.29 & 5.55 & 0.11 & 2.30 & 4.78 & 4.73 & 1.94 & 0.21 & na & 96.88 \\
\hline TS-698 & dnt & SS & 63.12 & 0.95 & 16.35 & 5.41 & 0.10 & 2.18 & 4.71 & 4.44 & 2.10 & 0.23 & na & 98.24 \\
\hline
\end{tabular}




\begin{tabular}{|c|c|c|c|c|c|c|c|c|c|c|c|c|c|c|}
\hline \multicolumn{15}{|c|}{ Dacite of Lewis Glacier headwall—Continued } \\
\hline \multicolumn{15}{|c|}{ Dacite of Lane Plateau } \\
\hline 662 & 49 & 4 & 5 & 24 & 29 & 11 & 36 & 2 & 27 & 297 & 23 & 51 & 96 & 274 \\
\hline 608 & 43 & na & 8 & 27 & 20 & 14 & 34 & na & 26 & 370 & 67 & 53 & 100 & 319 \\
\hline
\end{tabular}

\begin{tabular}{|c|c|c|c|c|c|c|c|c|c|c|c|c|c|c|}
\hline \multicolumn{15}{|c|}{ Dacite of Mesa Creek } \\
\hline na & na & na & na & na & na & na & na & na & na & na & na & na & na & na \\
\hline \multicolumn{15}{|c|}{ Dacite southeast of Moraine Lake } \\
\hline 653 & 36 & $<5$ & 5 & 14 & 16 & 10 & 24 & 3 & 38 & 390 & 92 & 22 & 59 & 216 \\
\hline 666 & 38 & na & 12 & 22 & 18 & 13 & 24 & na & 44 & 383 & 116 & 32 & 71 & 292 \\
\hline 690 & 36 & $<5$ & 10 & 14 & 13 & 10 & 35 & 3 & 42 & 360 & 73 & 25 & 59 & 234 \\
\hline 700 & 42 & $<5$ & 10 & 15 & 16 & 9 & 33 & 3 & 42 & 356 & 77 & 24 & 63 & 234 \\
\hline 671 & 41 & $<5$ & 3 & 14 & 19 & 9 & 28 & 3 & 37 & 394 & 87 & 23 & 60 & 218 \\
\hline 667 & 39 & $<5$ & 4 & 16 & 18 & 10 & 24 & 3 & 37 & 395 & 90 & 24 & 67 & 219 \\
\hline 720 & 40 & $<5$ & 10 & 15 & 19 & 9 & 30 & 3 & 41 & 351 & 75 & 25 & 70 & 234 \\
\hline 738 & 42 & $<5$ & 7 & 13 & 18 & 9 & 33 & 3 & 43 & 343 & 60 & 24 & 57 & 234 \\
\hline 675 & 42 & $<5$ & 2 & 14 & 13 & 10 & $<10$ & 3 & 37 & 393 & 89 & 22 & 61 & 214 \\
\hline 698 & 38 & $<5$ & 2 & 13 & 16 & 10 & 24 & 3 & 37 & 383 & 69 & 23 & 56 & 222 \\
\hline 664 & 39 & $<5$ & 7 & 15 & 15 & 10 & 36 & 3 & 36 & 397 & 85 & 24 & 62 & 217 \\
\hline 612 & 42 & 3 & 11 & 19 & 18 & 10 & 22 & 0 & 37 & 396 & 90 & 26 & 67 & 207 \\
\hline 616 & 44 & 3 & 9 & 20 & 20 & 10 & 20 & 0 & 38 & 398 & 91 & 25 & 69 & 209 \\
\hline
\end{tabular}

Dacite north of Moraine Lake

\begin{tabular}{|c|c|c|c|c|c|c|c|c|c|c|c|c|c|c|}
\hline na & na & na & na & na & na & na & na & na & na & na & na & na & na & na \\
\hline 680 & 37 & na & 23 & 22 & 21 & 14 & 20 & na & 49 & 370 & 108 & 38 & 70 & 296 \\
\hline na & na & na & na & na & na & na & na & na & na & na & na & na & na & na \\
\hline 753 & 42 & $<5$ & 10 & 15 & 18 & 10 & 31 & 3 & 45 & 339 & 58 & 25 & 57 & 237 \\
\hline 737 & 43 & $<5$ & 6 & 13 & 17 & 9 & 25 & 3 & 45 & 336 & 68 & 23 & 58 & 231 \\
\hline 753 & 40 & $<5$ & 15 & 14 & 15 & 9 & 25 & 3 & 44 & 333 & 62 & 23 & 56 & 231 \\
\hline 698 & 38 & $<5$ & $<2$ & 13 & 14 & 10 & 41 & 3 & 38 & 364 & 73 & 21 & 52 & 221 \\
\hline 738 & 44 & $<5$ & 10 & 14 & 19 & 9 & 30 & 3 & 44 & 347 & 60 & 25 & 51 & 232 \\
\hline 711 & 42 & $<5$ & 2 & 13 & 15 & 9 & 24 & 3 & 41 & 364 & 75 & 20 & 55 & 215 \\
\hline 742 & 36 & $<5$ & 7 & 14 & 13 & 9 & 21 & 3 & 45 & 323 & 80 & 20 & 52 & 224 \\
\hline \multicolumn{15}{|c|}{ Dacite of Middle Sister summit } \\
\hline 717 & 45 & 12 & 30 & 19 & 20 & 12 & 22 & 12 & 65 & 291 & 67 & 28 & 54 & 275 \\
\hline 696 & 45 & 14 & 36 & 19 & 22 & 12 & 26 & 14 & 62 & 307 & 76 & 30 & 55 & 273 \\
\hline 654 & 47 & 15 & 46 & 20 & 22 & 12 & 27 & 18 & 54 & 339 & 107 & 31 & 64 & 265 \\
\hline 696 & 45 & 12 & 32 & 19 & 20 & 12 & 30 & 13 & 60 & 312 & 77 & 28 & 57 & 272 \\
\hline \multicolumn{15}{|c|}{ Dacite coulee west of Moraine Lake } \\
\hline 632 & 37 & $<3$ & 9 & 21 & 17 & 12 & 18 & 7 & 40 & 383 & 83 & 25 & 70 & 226 \\
\hline na & na & na & na & na & na & na & na & na & na & na & na & na & na & na \\
\hline 637 & 40 & 6 & 7 & 19 & 20 & 12 & 24 & 7 & 40 & 382 & 81 & 24 & 75 & 226 \\
\hline 687 & 37 & $<5$ & 2 & 15 & 15 & 10 & 32 & 3 & 39 & 380 & 73 & 22 & 60 & 225 \\
\hline \multicolumn{15}{|c|}{ Dacite north of Teardrop Pool } \\
\hline 565 & 33 & 16 & 47 & 19 & 18 & 7 & 20 & 7 & 40 & 373 & 120 & 24 & 67 & 186 \\
\hline 552 & 32 & 15 & 72 & 19 & 15 & 6 & 17 & 7 & 38 & 378 & 122 & 24 & 68 & 180 \\
\hline 567 & 31 & 16 & 64 & 19 & 18 & 7 & 16 & 8 & 41 & 378 & 136 & 24 & 78 & 185 \\
\hline
\end{tabular}


Table 1. Chemical data for Three Sisters volcanic cluster.-Continued

\begin{tabular}{|c|c|c|c|c|c|c|c|c|c|c|c|c|c|c|}
\hline Sample & $\begin{array}{l}\text { Unit } \\
\text { label }\end{array}$ & $\begin{array}{c}\text { Volcanic } \\
\text { group }\end{array}$ & $\mathrm{SiO}_{2}$ & $\mathrm{TiO}_{2}$ & $\mathrm{Al}_{2} \mathrm{O}_{3}$ & $\mathrm{FeO} *$ & MnO & MgO & $\mathrm{CaO}$ & $\mathrm{Na}_{2} \mathrm{O}$ & $\mathrm{K}_{2} \mathrm{O}$ & $\mathbf{P}_{2} \mathbf{O}_{5}$ & LOI & $\begin{array}{c}\text { Original } \\
\text { total }\end{array}$ \\
\hline \multicolumn{15}{|c|}{ Silicic dacite north of Teardrop Pool } \\
\hline TS-483 & $\mathrm{dnt}^{\prime}$ & $\mathrm{SS}$ & 67.08 & 0.70 & 15.34 & 4.18 & 0.09 & 1.71 & 3.63 & 3.61 & 3.03 & 0.22 & 1.26 & 99.33 \\
\hline \multicolumn{15}{|c|}{ Dacite pumice fall of Prouty Glacier headwall } \\
\hline TS-204 & $\mathrm{dpg}$ & $\mathrm{SS}$ & 64.56 & 1.01 & 15.99 & 5.27 & 0.11 & 1.44 & 3.72 & 4.99 & 2.15 & 0.36 & 2.60 & 96.58 \\
\hline \multicolumn{15}{|c|}{ Dacite of Red Meadow } \\
\hline TS-189 & drm & $\mathrm{SS}$ & 63.86 & 1.03 & 16.12 & 5.40 & 0.11 & 1.69 & 4.17 & 4.90 & 2.03 & 0.29 & 0.76 & 98.26 \\
\hline TS-431 & drm & SS & 63.73 & 1.04 & 16.38 & 5.42 & 0.11 & 1.78 & 4.21 & 4.62 & 1.98 & 0.32 & 0.41 & 99.09 \\
\hline TS-432 & drm & SS & 65.30 & 0.86 & 16.23 & 4.72 & 0.09 & 1.60 & 4.05 & 4.21 & 2.28 & 0.26 & 0.24 & 98.83 \\
\hline TS-460 & drm & SS & 63.57 & 1.05 & 16.30 & 5.52 & 0.11 & 1.82 & 4.34 & 4.55 & 2.01 & 0.32 & 1.05 & 98.39 \\
\hline TS-461 & drm & SS & 63.97 & 1.04 & 16.32 & 5.44 & 0.11 & 1.72 & 4.22 & 4.45 & 2.00 & 0.33 & $<0.01$ & 100.11 \\
\hline TS-497 & $\mathrm{drm}$ & SS & 64.49 & 1.01 & 16.32 & 5.21 & 0.11 & 1.60 & 4.09 & 4.46 & 1.98 & 0.33 & 0.40 & 99.46 \\
\hline TS-511 & drm & SS & 64.30 & 1.01 & 16.05 & 5.40 & 0.11 & 1.64 & 4.21 & 4.55 & 2.01 & 0.32 & 0.30 & 98.67 \\
\hline TS-570 & drm & SS & 63.70 & 1.05 & 16.18 & 5.34 & 0.11 & 1.65 & 4.20 & 5.08 & 2.03 & 0.26 & 0.23 & 98.50 \\
\hline TS-571 & $\mathrm{drm}$ & SS & 63.04 & 1.11 & 16.41 & 5.61 & 0.12 & 1.80 & 4.39 & 4.91 & 1.91 & 0.29 & 0.23 & 99.54 \\
\hline TS-575 & drm & SS & 64.25 & 1.02 & 16.16 & 5.18 & 0.11 & 1.59 & 4.04 & 4.91 & 2.07 & 0.28 & 0.18 & 99.83 \\
\hline TS-619 & drm & SS & 63.40 & 1.06 & 16.21 & 5.45 & 0.12 & 1.77 & 4.28 & 5.04 & 1.99 & 0.27 & na & 97.48 \\
\hline TS-620 & drm & SS & 63.87 & 1.05 & 16.06 & 5.35 & 0.12 & 1.70 & 4.12 & 5.06 & 1.99 & 0.28 & na & 99.38 \\
\hline TS-623 & $\mathrm{drm}$ & SS & 64.27 & 1.00 & 16.10 & 5.10 & 0.12 & 1.61 & 4.07 & 5.05 & 2.03 & 0.26 & na & 99.90 \\
\hline TS-635 & $\mathrm{drm}$ & SS & 64.05 & 1.01 & 16.08 & 5.24 & 0.11 & 1.66 & 4.15 & 5.00 & 2.04 & 0.26 & na & 98.90 \\
\hline TS-677 & drm & SS & 64.08 & 1.01 & 16.16 & 5.12 & 0.11 & 1.62 & 4.10 & 5.10 & 2.04 & 0.26 & na & 98.73 \\
\hline TS-678 & drm & SS & 63.92 & 1.02 & 16.27 & 5.21 & 0.11 & 1.63 & 4.11 & 5.04 & 2.02 & 0.27 & na & 99.23 \\
\hline TS-680 & drm & SS & 66.34 & 0.75 & 15.80 & 4.13 & 0.08 & 1.47 & 3.80 & 4.66 & 2.40 & 0.18 & na & 98.23 \\
\hline TS-719 & drm & SS & 63.77 & 1.04 & 16.24 & 5.22 & 0.12 & 1.64 & 4.17 & 5.11 & 2.00 & 0.27 & na & 99.47 \\
\hline TS-720 & drm & SS & 63.08 & 1.09 & 16.31 & 5.61 & 0.12 & 1.76 & 4.44 & 5.00 & 1.92 & 0.27 & na & 99.04 \\
\hline TS-723 & drm & SS & 62.64 & 1.12 & 16.22 & 5.73 & 0.12 & 1.97 & 4.58 & 4.98 & 1.94 & 0.30 & na & 100.28 \\
\hline
\end{tabular}

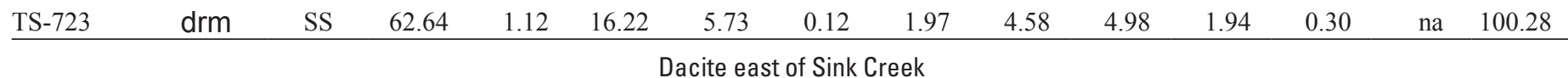

\begin{tabular}{|c|c|c|c|c|c|c|c|c|c|c|c|c|c|c|}
\hline$\underline{\text { TS-641 }}$ & dse & $\mathrm{P}$ & 66.20 & 0.63 & 16.47 & 4.02 & 0.09 & 1.24 & 3.65 & 5.04 & 2.05 & 0.20 & na & 97.32 \\
\hline \multicolumn{15}{|c|}{ Dacite north of Separation Creek } \\
\hline TS-228 & dsn & MS & 64.31 & 0.97 & 16.05 & 5.65 & 0.14 & 1.32 & 3.46 & 5.53 & 1.80 & 0.37 & -0.02 & 99.28 \\
\hline$\underline{\text { TS-257 }}$ & dsn & MS & 64.40 & 0.97 & 16.00 & 5.64 & 0.14 & 1.28 & 3.41 & 5.59 & 1.81 & 0.37 & 0.06 & 99.61 \\
\hline \multicolumn{15}{|c|}{ Dacite of Sister Spring } \\
\hline TS-101 & dss & MS & 63.58 & 1.01 & 16.32 & 5.69 & 0.14 & 1.43 & 3.71 & 5.56 & 1.69 & 0.46 & $<0.01$ & 100.10 \\
\hline TS-387 & dss & MS & 63.74 & 1.02 & 15.99 & 5.73 & 0.14 & 1.49 & 3.80 & 5.58 & 1.70 & 0.42 & $<0.01$ & 99.69 \\
\hline \multicolumn{15}{|c|}{ Dacite domes southwest of Middle Sister } \\
\hline TS-222 & dsw & MS & 65.45 & 0.72 & 16.19 & 5.15 & 0.14 & 0.93 & 2.79 & 6.13 & 1.85 & 0.26 & -0.10 & 99.67 \\
\hline TS-222A & dsw & MS & 65.47 & 0.71 & 16.14 & 5.18 & 0.14 & 0.92 & 2.83 & 6.12 & 1.83 & 0.26 & -0.01 & 99.34 \\
\hline TS-223 & dsw & MS & 65.42 & 0.70 & 16.33 & 5.14 & 0.14 & 0.88 & 2.79 & 6.10 & 1.84 & 0.26 & -0.08 & 99.42 \\
\hline TS-224 & dsw & MS & 65.48 & 0.71 & 16.12 & 5.22 & 0.14 & 0.95 & 2.77 & 6.10 & 1.84 & 0.27 & 0.08 & 99.48 \\
\hline \multicolumn{15}{|c|}{ Dacite of Todd Lake } \\
\hline TS-700 & $\mathrm{dtl}$ & $\mathrm{P}$ & 62.62 & 1.08 & 16.50 & 5.80 & 0.12 & 1.83 & 4.33 & 4.85 & 2.17 & 0.31 & na & 98.65 \\
\hline TS-782 & $\mathrm{dtl}$ & $\mathrm{P}$ & 63.49 & 0.99 & 16.10 & 5.64 & 0.11 & 1.83 & 4.25 & 4.68 & 2.22 & 0.28 & na & 99.64 \\
\hline TS-783 & $\mathrm{dtl}$ & $\mathrm{P}$ & 62.75 & 1.15 & 15.83 & 6.26 & 0.14 & 1.84 & 4.33 & 4.89 & 2.07 & 0.35 & na & 99.92 \\
\hline \multicolumn{15}{|c|}{ Dacite west of Lost Creek Glacier } \\
\hline TS-315 & $d w l$ & $\mathrm{SS}$ & 63.10 & 1.07 & 16.15 & 5.78 & 0.12 & 1.82 & 4.34 & 5.03 & 1.90 & 0.29 & 0.01 & 99.29 \\
\hline TS-545 & $d w l$ & SS & 64.60 & 0.92 & 15.85 & 5.19 & 0.10 & 1.85 & 3.99 & 4.68 & 2.21 & 0.21 & 0.14 & 99.29 \\
\hline \multicolumn{15}{|c|}{ Dacite of Wickiup Plain } \\
\hline TS-64 & dwp & $\mathrm{SS}$ & 64.05 & 0.99 & 16.29 & 5.06 & 0.11 & 1.61 & 4.08 & 5.06 & 2.04 & 0.32 & 0.06 & 99.67 \\
\hline TS-135 & dwp & SS & 64.16 & 0.99 & 16.27 & 5.08 & 0.11 & 1.58 & 4.08 & 4.98 & 2.05 & 0.30 & 0.00 & 99.19 \\
\hline
\end{tabular}




\begin{tabular}{|c|c|c|c|c|c|c|c|c|c|c|c|c|c|c|}
\hline $\mathrm{Ba}$ & Ce & $\mathrm{Cr}$ & Cu & $\mathbf{G a}$ & La & Nb & Nd & $\mathrm{Ni}$ & $\mathbf{R b}$ & $\mathrm{Sr}$ & $\mathbf{V}$ & $\mathbf{Y}$ & Zn & $\mathrm{Zr}$ \\
\hline \multicolumn{15}{|c|}{ Silicic dacite north of Teardrop Pool } \\
\hline 724 & 33 & 5 & 16 & 13 & 12 & 7 & 26 & 3 & 52 & 298 & 81 & 19 & 43 & 178 \\
\hline \multicolumn{15}{|c|}{ Dacite pumice fall of Prouty Glacier headwall } \\
\hline 634 & 41 & $<5$ & 11 & 18 & 21 & 12 & 27 & 5 & 37 & 345 & 69 & 30 & 79 & 241 \\
\hline \multicolumn{15}{|c|}{ Dacite of Red Meadow } \\
\hline 608 & 37 & $<5$ & 8 & 21 & 17 & 11 & 19 & 7 & 38 & 388 & 96 & 25 & 74 & 218 \\
\hline 676 & 40 & $<5$ & 3 & 14 & 17 & 10 & 22 & 3 & 35 & 404 & 87 & 24 & 61 & 225 \\
\hline 721 & 33 & $<5$ & 22 & 14 & 14 & 8 & 26 & 3 & 46 & 342 & 91 & 19 & 51 & 213 \\
\hline 649 & 37 & $<5$ & 4 & 15 & 13 & 10 & 24 & 3 & 36 & 399 & 93 & 23 & 60 & 211 \\
\hline 674 & 40 & $<5$ & 5 & 14 & 15 & 10 & 23 & 3 & 36 & 402 & 93 & 23 & 64 & 218 \\
\hline 695 & 42 & $<5$ & 4 & 13 & 20 & 10 & 30 & 3 & 32 & 391 & 83 & 25 & 63 & 222 \\
\hline na & na & na & na & na & na & na & na & na & na & na & na & na & na & na \\
\hline 684 & 37 & $<5$ & 2 & 14 & 16 & 12 & 30 & 3 & 35 & 387 & 102 & 27 & 53 & 259 \\
\hline 643 & 40 & $<5$ & 4 & 15 & 16 & 13 & 23 & 3 & 33 & 400 & 113 & 28 & 59 & 253 \\
\hline 659 & 37 & $<5$ & $<2$ & 15 & 13 & 12 & 32 & 3 & 37 & 388 & 121 & 27 & 52 & 256 \\
\hline 589 & 41 & 2 & 12 & 20 & 17 & 10 & 22 & 0 & 36 & 398 & 105 & 26 & 73 & 202 \\
\hline 600 & 40 & 2 & 9 & 18 & 19 & 10 & 21 & 0 & 37 & 398 & 96 & 26 & 73 & 207 \\
\hline 623 & 39 & 1 & 9 & 19 & 22 & 11 & 21 & 0 & 38 & 401 & 95 & 26 & 72 & 211 \\
\hline 602 & 36 & 2 & 10 & 18 & 18 & 11 & 18 & 0 & 38 & 401 & 96 & 26 & 72 & 206 \\
\hline 592 & 42 & 2 & 8 & 18 & 19 & 11 & 20 & 0 & 37 & 390 & 89 & 25 & 74 & 207 \\
\hline 621 & 34 & 3 & 8 & 19 & 20 & 10 & 17 & 0 & 36 & 394 & 96 & 25 & 76 & 209 \\
\hline 649 & 35 & 12 & 20 & 17 & 17 & 8 & 16 & 5 & 50 & 319 & 76 & 20 & 56 & 195 \\
\hline 600 & 44 & 3 & 7 & 19 & 20 & 11 & 22 & 0 & 37 & 401 & 95 & 27 & 75 & 208 \\
\hline 567 & 39 & 2 & 11 & 18 & 18 & 10 & 22 & 0 & 34 & 412 & 111 & 26 & 73 & 200 \\
\hline 610 & 42 & 6 & 11 & 19 & 23 & 12 & 24 & 2 & 36 & 444 & 111 & 28 & 80 & 209 \\
\hline
\end{tabular}

Dacite east of Sink Creek

\begin{tabular}{|c|c|c|c|c|c|c|c|c|c|c|c|c|c|c|}
\hline 617 & 33 & 1 & 8 & 20 & 15 & 8 & 17 & 0 & 38 & 401 & 53 & 19 & 58 & 181 \\
\hline \multicolumn{15}{|c|}{ Dacite north of Separation Creek } \\
\hline 660 & 49 & $<5$ & 19 & 21 & 22 & 12 & 25 & 7 & 30 & 382 & 47 & 43 & 91 & 238 \\
\hline 664 & 47 & 5 & 24 & 22 & 21 & 11 & 26 & 8 & 29 & 373 & 50 & 37 & 88 & 237 \\
\hline \multicolumn{15}{|c|}{ Dacite of Sister Spring } \\
\hline 636 & 44 & $<3$ & 9 & 22 & 21 & 11 & 27 & 9 & 26 & 405 & 53 & 36 & 91 & 222 \\
\hline 626 & 42 & na & 16 & 26 & 20 & 12 & 26 & na & 28 & 433 & 84 & 46 & 99 & 275 \\
\hline \multicolumn{15}{|c|}{ Dacite domes southwest of Middle Sister } \\
\hline 638 & 41 & $<5$ & 6 & 24 & 18 & 12 & 31 & 8 & 27 & 293 & 21 & 41 & 95 & 281 \\
\hline 644 & 40 & $<5$ & 4 & 23 & 17 & 11 & 24 & 7 & 26 & 297 & 25 & 37 & 93 & 271 \\
\hline 645 & 41 & $<5$ & 7 & 24 & 16 & 12 & 29 & 9 & 26 & 297 & 21 & 37 & 96 & 275 \\
\hline 639 & 38 & 6 & 6 & 23 & 17 & 11 & 26 & 8 & 27 & 292 & 19 & 40 & 93 & 277 \\
\hline \multicolumn{15}{|c|}{ Dacite of Todd Lake } \\
\hline 682 & 55 & 5 & 25 & 20 & 26 & 14 & 28 & 2 & 44 & 329 & 106 & 38 & 85 & 276 \\
\hline 633 & 55 & 10 & 29 & 19 & 26 & 13 & 31 & 7 & 58 & 360 & 113 & 38 & 76 & 257 \\
\hline 683 & 66 & 7 & 29 & 21 & 26 & 14 & 34 & 6 & 47 & 344 & 121 & 44 & 91 & 267 \\
\hline \multicolumn{15}{|c|}{ Dacite west of Lost Creek Glacier } \\
\hline 592 & 34 & $<5$ & 22 & 21 & 17 & 10 & 19 & 7 & 37 & 394 & 96 & 28 & 69 & 214 \\
\hline na & na & na & na & na & na & na & na & na & na & na & na & na & na & na \\
\hline \multicolumn{15}{|c|}{ Dacite of Wickiup Plain } \\
\hline 612 & 37 & $<3$ & 12 & 20 & 18 & 12 & 22 & $<2$ & 39 & 401 & 91 & 25 & 71 & 219 \\
\hline na & na & na & na & na & na & na & na & na & na & na & na & na & na & na \\
\hline
\end{tabular}


Table 1. Chemical data for Three Sisters volcanic cluster.-Continued

\begin{tabular}{|c|c|c|c|c|c|c|c|c|c|c|c|c|c|c|}
\hline Sample & $\begin{array}{l}\text { Unit } \\
\text { label }\end{array}$ & $\begin{array}{l}\text { Volcanic } \\
\text { group }\end{array}$ & $\mathrm{SiO}_{2}$ & $\mathrm{TiO}_{2}$ & $\mathrm{Al}_{2} \mathrm{O}_{3}$ & $\mathrm{FeO} *$ & MnO & MgO & $\mathrm{CaO}$ & $\mathrm{Na}_{2} \mathrm{O}$ & $\mathrm{K}_{2} \mathrm{O}$ & $\mathrm{P}_{2} \mathrm{O}_{5}$ & LOI & $\begin{array}{c}\text { Original } \\
\text { total }\end{array}$ \\
\hline \multicolumn{15}{|c|}{ Dacite of Wickiup Plain-Continued } \\
\hline TS-136 & dwp & SS & 64.00 & 1.00 & 16.48 & 5.12 & 0.11 & 1.58 & 4.01 & 4.96 & 2.04 & 0.30 & 0.26 & 99.14 \\
\hline TS-137 & dwp & SS & 64.21 & 0.99 & 16.25 & 5.02 & 0.11 & 1.58 & 4.10 & 5.00 & 2.04 & 0.30 & 0.16 & 98.66 \\
\hline TS-345 & dwp & SS & 64.49 & 0.98 & 16.17 & 5.03 & 0.11 & 1.50 & 3.84 & 5.06 & 2.10 & 0.32 & 0.11 & 99.16 \\
\hline \multicolumn{15}{|c|}{ Basaltic andesite of Black Crater } \\
\hline TS-746 & $\mathrm{mbc}$ & $\mathrm{P}$ & 56.22 & 1.02 & 17.67 & 7.06 & 0.13 & 4.57 & 7.72 & 3.75 & 1.12 & 0.34 & na & 98.93 \\
\hline NS-07-197 & $\mathrm{mbc}$ & $\mathrm{P}$ & 55.11 & 1.00 & 18.50 & 6.98 & 0.12 & 4.52 & 8.27 & 3.85 & 0.96 & 0.27 & na & 100.03 \\
\hline NS-07-199 & $\mathrm{mbc}$ & $\mathrm{P}$ & 55.85 & 1.33 & 17.27 & 8.22 & 0.15 & 3.93 & 7.29 & 4.35 & 0.95 & 0.28 & na & 100.19 \\
\hline \multicolumn{15}{|c|}{ Basaltic andesite of Bare Lake } \\
\hline TS-785 & $\mathrm{mbl}$ & $\mathrm{P}$ & 55.79 & 1.67 & 16.22 & 9.53 & 0.16 & 3.32 & 7.01 & 4.50 & 1.02 & 0.36 & na & 99.89 \\
\hline \multicolumn{15}{|c|}{ Basaltic andesite of Broken Top } \\
\hline TS-165 & $\mathrm{mbt}$ & BT & 54.15 & 0.98 & 18.25 & 7.28 & 0.12 & 5.77 & 8.41 & 3.49 & 0.86 & 0.29 & 1.55 & 97.67 \\
\hline TS-322 & $\mathrm{mbt}$ & BT & 55.98 & 1.47 & 16.68 & 9.07 & 0.15 & 3.39 & 7.24 & 4.45 & 0.91 & 0.25 & $<0.01$ & 99.10 \\
\hline TS-327 & $\mathrm{mbt}$ & BT & 54.69 & 0.97 & 18.70 & 6.93 & 0.12 & 4.99 & 8.42 & 3.82 & 0.73 & 0.23 & 0.30 & 99.07 \\
\hline TS-328 & $\mathrm{mbt}$ & BT & 56.02 & 1.53 & 16.40 & 9.37 & 0.15 & 3.37 & 7.15 & 4.43 & 0.90 & 0.28 & $<0.01$ & 99.57 \\
\hline TS-329 & $\mathrm{mbt}$ & BT & 56.08 & 1.46 & 16.77 & 8.89 & 0.15 & 3.36 & 7.15 & 4.38 & 0.98 & 0.37 & $<0.01$ & 98.57 \\
\hline TS-330 & $\mathrm{mbt}$ & BT & 56.71 & 1.19 & 18.20 & 6.91 & 0.13 & 3.30 & 7.58 & 4.24 & 0.99 & 0.34 & $<0.01$ & 99.58 \\
\hline TS-333 & $\mathrm{mbt}$ & BT & 55.68 & 1.78 & 16.02 & 9.56 & 0.16 & 3.43 & 7.05 & 4.57 & 0.97 & 0.37 & $<0.01$ & 99.45 \\
\hline TS-334 & $\mathrm{mbt}$ & BT & 56.30 & 1.44 & 16.95 & 8.00 & 0.15 & 3.50 & 7.61 & 4.42 & 0.96 & 0.27 & na & 100.09 \\
\hline TS-334R & $\mathrm{mbt}$ & BT & 56.22 & 1.44 & 16.95 & 8.14 & 0.15 & 3.51 & 7.58 & 4.39 & 0.96 & 0.27 & na & 100.29 \\
\hline TS-341 & $\mathrm{mbt}$ & BT & 52.83 & 1.32 & 19.66 & 7.84 & 0.13 & 3.47 & 9.74 & 3.66 & 0.67 & 0.29 & 0.45 & 98.80 \\
\hline TS-342 & $\mathrm{mbt}$ & BT & 55.77 & 1.57 & 17.16 & 8.69 & 0.14 & 3.00 & 7.55 & 4.34 & 1.03 & 0.34 & $<0.01$ & 99.82 \\
\hline TS-450 & $\mathrm{mbt}$ & BT & 52.54 & 1.16 & 20.51 & 7.40 & 0.12 & 3.62 & 9.98 & 3.39 & 0.62 & 0.25 & 0.06 & 99.53 \\
\hline TS-451 & $\mathrm{mbt}$ & BT & 57.79 & 1.68 & 16.03 & 8.75 & 0.16 & 2.87 & 6.06 & 4.56 & 1.29 & 0.41 & $<0.01$ & 99.44 \\
\hline TS-454 & $\mathrm{mbt}$ & BT & 54.24 & 1.16 & 18.58 & 8.27 & 0.14 & 4.38 & 8.21 & 3.61 & 0.75 & 0.26 & 0.36 & 99.15 \\
\hline TS-501 & $\mathrm{mbt}$ & BT & 56.07 & 1.50 & 17.17 & 8.47 & 0.15 & 3.44 & 7.25 & 4.05 & 1.10 & 0.40 & $<0.01$ & 100.37 \\
\hline TS-515 & $\mathrm{mbt}$ & BT & 56.49 & 1.42 & 16.85 & 9.12 & 0.15 & 3.39 & 7.01 & 4.03 & 0.90 & 0.24 & 0.32 & 98.74 \\
\hline TS-524 & $\mathrm{mbt}$ & BT & 54.11 & 1.31 & 18.47 & 8.64 & 0.14 & 4.33 & 7.80 & 3.84 & 0.67 & 0.29 & 0.14 & 98.67 \\
\hline TS-529 & $\mathrm{mbt}$ & BT & 57.28 & 1.80 & 15.92 & 8.91 & 0.18 & 2.95 & 6.19 & 4.80 & 1.24 & 0.33 & $<0.01$ & 99.47 \\
\hline TS-568 & $\mathrm{mbt}$ & BT & 55.89 & 1.56 & 16.53 & 9.24 & 0.16 & 3.42 & 6.99 & 4.39 & 1.10 & 0.32 & $<0.01$ & 99.43 \\
\hline TS-675 & $\mathrm{mbt}$ & BT & 55.50 & 1.51 & 17.42 & 8.26 & 0.15 & 3.44 & 7.39 & 4.53 & 1.07 & 0.34 & na & 99.25 \\
\hline TS-682 & $\mathrm{mbt}$ & BT & 55.82 & 1.74 & 16.40 & 9.06 & 0.16 & 3.40 & 6.94 & 4.51 & 1.13 & 0.44 & na & 100.20 \\
\hline TS-683 & $\mathrm{mbt}$ & BT & 55.72 & 1.74 & 16.51 & 9.10 & 0.16 & 3.41 & 6.96 & 4.44 & 1.12 & 0.44 & na & 100.20 \\
\hline TS-683R & $\mathrm{mbt}$ & BT & 55.72 & 1.73 & 16.51 & 9.10 & 0.16 & 3.41 & 6.93 & 4.46 & 1.13 & 0.44 & na & 99.73 \\
\hline TS-684 & $\mathrm{mbt}$ & BT & 57.70 & 1.68 & 16.16 & 8.45 & 0.17 & 2.81 & 6.05 & 4.93 & 1.30 & 0.36 & na & 99.62 \\
\hline TS-685 & $\mathrm{mbt}$ & BT & 54.61 & 1.92 & 16.22 & 9.73 & 0.17 & 3.59 & 7.46 & 4.53 & 0.98 & 0.36 & na & 100.38 \\
\hline TS-686 & $\mathrm{mbt}$ & BT & 54.80 & 1.65 & 17.16 & 9.35 & 0.17 & 3.33 & 7.35 & 4.60 & 0.92 & 0.28 & na & 99.24 \\
\hline TS-715 & $\mathrm{mbt}$ & BT & 55.39 & 1.80 & 16.43 & 9.26 & 0.16 & 3.37 & 7.23 & 4.68 & 0.96 & 0.33 & na & 99.63 \\
\hline TS-717 & $\mathrm{mbt}$ & BT & 53.68 & 1.53 & 17.65 & 8.78 & 0.15 & 3.88 & 8.44 & 4.19 & 0.90 & 0.38 & na & 100.07 \\
\hline \multicolumn{15}{|c|}{ Basaltic andesite of Whychus Creek bridge } \\
\hline TS-448 & mbw & BT & 52.90 & 1.32 & 18.00 & 8.62 & 0.14 & 5.34 & 8.68 & 3.51 & 0.78 & 0.31 & 0.11 & 99.60 \\
\hline TS-456 & mbw & BT & 52.93 & 1.32 & 18.14 & 8.49 & 0.14 & 5.28 & 8.74 & 3.43 & 0.80 & 0.32 & 0.07 & 99.36 \\
\hline TS-659 & mbw & BT & 52.91 & 1.35 & 17.99 & 8.17 & 0.15 & 5.39 & 8.72 & 3.85 & 0.80 & 0.27 & na & 99.96 \\
\hline \multicolumn{15}{|c|}{ Basaltic andesite of Camp Lake } \\
\hline TS-1 & $\mathrm{mcl}$ & MS & 56.31 & 1.33 & 17.00 & 8.86 & 0.14 & 3.37 & 6.80 & 4.46 & 1.01 & 0.31 & $<0.01$ & 99.58 \\
\hline TS-2 & $\mathrm{mcl}$ & MS & 56.78 & 1.32 & 17.06 & 8.60 & 0.14 & 3.24 & 6.63 & 4.48 & 1.04 & 0.31 & $<0.01$ & 99.81 \\
\hline TS-22 & $\mathrm{mcl}$ & MS & 56.45 & 1.33 & 17.09 & 8.83 & 0.14 & 3.33 & 6.81 & 4.33 & 0.99 & 0.31 & $<0.01$ & 99.68 \\
\hline TS-169 & $\mathrm{mcl}$ & MS & 56.34 & 1.34 & 17.10 & 8.90 & 0.14 & 3.33 & 6.88 & 4.27 & 1.02 & 0.28 & 0.01 & 98.99 \\
\hline TS-186 & $\mathrm{mcl}$ & MS & 56.79 & 1.31 & 16.99 & 8.64 & 0.14 & 3.28 & 6.79 & 4.36 & 1.04 & 0.27 & 0.12 & 99.09 \\
\hline TS-446 & $\mathrm{mcl}$ & MS & 56.59 & 1.32 & 17.14 & 8.73 & 0.14 & 3.42 & 6.79 & 4.14 & 1.03 & 0.31 & $<0.01$ & 99.97 \\
\hline
\end{tabular}




\begin{tabular}{|c|c|c|c|c|c|c|c|c|c|c|c|c|c|c|}
\hline $\mathrm{Ba}$ & $\mathrm{Ce}$ & $\mathrm{Cr}$ & $\mathrm{Cu}$ & $\mathbf{G a}$ & La & $\mathbf{N b}$ & Nd & $\mathrm{Ni}$ & $\mathbf{R b}$ & Sr & V & $\mathbf{Y}$ & $\mathrm{Zn}$ & $\mathrm{Zr}$ \\
\hline \multicolumn{15}{|c|}{ Dacite of Wickiup Plain-Continued } \\
\hline na & na & na & na & na & na & na & na & na & na & na & na & na & na & na \\
\hline na & na & na & na & na & na & na & na & na & na & na & na & na & na & na \\
\hline 650 & 39 & na & 9 & 23 & 18 & 15 & 22 & na & 40 & 406 & 112 & 38 & 76 & 286 \\
\hline \multicolumn{15}{|c|}{ Basaltic andesite of Black Crater } \\
\hline 492 & 49 & 84 & 50 & 20 & 23 & 12 & 28 & 62 & 18 & 533 & 163 & 26 & 84 & 192 \\
\hline 416 & 36 & 59 & 54 & 20 & 18 & 6 & 20 & 41 & 14 & 853 & 184 & 17 & 80 & 120 \\
\hline 373 & 30 & 16 & 72 & 19 & 13 & 6 & 20 & 8 & 14 & 570 & 217 & 23 & 85 & 137 \\
\hline \multicolumn{15}{|c|}{ Basaltic andesite of Bare Lake } \\
\hline 407 & 32 & 4 & 62 & 21 & 13 & 10 & 22 & 6 & 18 & 498 & 282 & 30 & 96 & 144 \\
\hline \multicolumn{15}{|c|}{ Basaltic andesite of Broken Top } \\
\hline 289 & 28 & 111 & 91 & 21 & 13 & 7 & 17 & 100 & 11 & 735 & 155 & 18 & 73 & 123 \\
\hline 318 & 29 & na & 71 & 23 & 10 & 8 & 13 & na & 16 & 527 & 321 & 31 & 85 & 150 \\
\hline 288 & 22 & 63 & 68 & 15 & 8 & 4 & $<10$ & 42 & 9 & 686 & 221 & 14 & 65 & 94 \\
\hline 339 & 27 & $<5$ & 77 & 17 & 8 & 5 & $<10$ & 3 & 12 & 489 & 297 & 22 & 77 & 118 \\
\hline 415 & 35 & $<5$ & 74 & 16 & 11 & 7 & 15 & 3 & 14 & 530 & 228 & 24 & 81 & 140 \\
\hline 357 & 25 & 25 & 49 & 16 & 7 & 6 & 22 & 3 & 17 & 510 & 198 & 23 & 66 & 130 \\
\hline 325 & 30 & na & 76 & 22 & 11 & 12 & 19 & na & 15 & 486 & 325 & 37 & 96 & 187 \\
\hline 337 & 25 & 38 & 64 & 19 & 14 & 7 & 19 & 6 & 16 & 472 & 239 & 26 & 84 & 135 \\
\hline 333 & 29 & 38 & 63 & 20 & 14 & 6 & 17 & 5 & 16 & 473 & 239 & 27 & 86 & 136 \\
\hline 263 & 22 & 19 & 54 & 16 & 9 & 6 & $<10$ & 3 & 8 & 626 & 275 & 20 & 62 & 104 \\
\hline 352 & 30 & $<5$ & 41 & 16 & 12 & 6 & $<10$ & 3 & 18 & 534 & 279 & 25 & 80 & 136 \\
\hline 242 & 12 & 6 & 53 & 15 & 10 & 3 & $<10$ & 3 & 8 & 745 & 204 & 13 & 49 & 76 \\
\hline 437 & 40 & $<5$ & 20 & 16 & 13 & 12 & 23 & 3 & 22 & 394 & 208 & 35 & 83 & 218 \\
\hline 285 & 23 & 50 & 71 & 15 & 9 & 5 & 10 & 23 & 15 & 568 & 207 & 17 & 65 & 109 \\
\hline 418 & 42 & $<5$ & 22 & 17 & 12 & 9 & 11 & 3 & 14 & 583 & 196 & 26 & 74 & 163 \\
\hline na & na & na & na & na & na & na & na & na & na & na & na & na & na & na \\
\hline na & na & na & na & na & na & na & na & na & na & na & na & na & na & na \\
\hline 427 & 40 & $<5$ & 19 & 15 & 11 & 11 & 13 & 10 & 21 & 399 & 217 & 35 & 84 & 212 \\
\hline 412 & 30 & $<5$ & 38 & 15 & 8 & 7 & $<10$ & 3 & 18 & 519 & 309 & 27 & 71 & 165 \\
\hline 391 & 35 & 23 & 71 & 20 & 17 & 9 & 22 & 9 & 14 & 577 & 221 & 28 & 92 & 156 \\
\hline 397 & 37 & 10 & 64 & 19 & 17 & 7 & 23 & 5 & 21 & 509 & 261 & 29 & 96 & 148 \\
\hline 408 & 37 & 9 & 49 & 20 & 18 & 8 & 23 & 4 & 21 & 513 & 266 & 29 & 98 & 148 \\
\hline 406 & 38 & 7 & 49 & 20 & 18 & 8 & 25 & 6 & 21 & 510 & 262 & 29 & 95 & 147 \\
\hline 431 & 46 & 9 & 25 & 20 & 20 & 12 & 29 & 1 & 21 & 384 & 222 & 38 & 97 & 216 \\
\hline 343 & 32 & 16 & 42 & 21 & 14 & 10 & 22 & 5 & 15 & 430 & 314 & 33 & 100 & 171 \\
\hline 354 & 26 & 2 & 50 & 21 & 13 & 7 & 19 & 4 & 15 & 487 & 266 & 27 & 99 & 127 \\
\hline 337 & 30 & 5 & 51 & 19 & 14 & 8 & 20 & 4 & 15 & 458 & 290 & 30 & 97 & 145 \\
\hline 361 & 37 & 19 & 41 & 20 & 16 & 8 & 23 & 11 & 13 & 636 & 257 & 25 & 87 & 135 \\
\hline \multicolumn{15}{|c|}{ Basaltic andesite of Whychus Creek bridge } \\
\hline 315 & 25 & 42 & 71 & 16 & 8 & 5 & $<10$ & 62 & 13 & 549 & 195 & 21 & 67 & 117 \\
\hline 321 & 25 & 41 & 79 & 16 & 10 & 6 & $<10$ & 53 & 13 & 549 & 203 & 21 & 72 & 120 \\
\hline 313 & 27 & 69 & 80 & 18 & 14 & 6 & 19 & 78 & 14 & 532 & 215 & 24 & 88 & 120 \\
\hline \multicolumn{15}{|c|}{ Basaltic andesite of Camp Lake } \\
\hline 383 & 29 & 5 & 81 & 22 & 13 & 8 & 11 & 9 & 15 & 546 & 253 & 21 & 93 & 135 \\
\hline 401 & 27 & 4 & 86 & 22 & 12 & 8 & $<7$ & 6 & 16 & 540 & 220 & 22 & 88 & 139 \\
\hline 386 & 28 & $<3$ & 66 & 20 & 13 & 8 & 12 & 2 & 15 & 552 & 231 & 21 & 87 & 136 \\
\hline 388 & 28 & $<5$ & 89 & 20 & 11 & 8 & $<10$ & 13 & 15 & 557 & 242 & 22 & 87 & 139 \\
\hline 391 & 29 & $<5$ & 89 & 19 & 14 & 8 & 11 & 6 & 17 & 550 & 223 & 22 & 88 & 137 \\
\hline 419 & 35 & $<5$ & 78 & 17 & 8 & 6 & $<10$ & 3 & 15 & 558 & 226 & 20 & 76 & 134 \\
\hline
\end{tabular}


Table 1. Chemical data for Three Sisters volcanic cluster.-Continued

\begin{tabular}{|c|c|c|c|c|c|c|c|c|c|c|c|c|c|c|}
\hline Sample & $\begin{array}{l}\text { Unit } \\
\text { label }\end{array}$ & $\begin{array}{c}\text { Volcanic } \\
\text { group }\end{array}$ & $\mathrm{SiO}_{2}$ & $\mathrm{TiO}_{2}$ & $\mathrm{Al}_{2} \mathrm{O}_{3}$ & $\mathrm{FeO}$ * & MnO & $\mathrm{MgO}$ & $\mathrm{CaO}$ & $\mathrm{Na}_{2} \mathrm{O}$ & $\mathbf{K}_{2} \mathbf{O}$ & $\mathbf{P}_{2} \mathbf{O}_{5}$ & LOI & $\begin{array}{c}\text { Original } \\
\text { total }\end{array}$ \\
\hline \multicolumn{15}{|c|}{ Basaltic andesite north and south of Demaris Lake } \\
\hline TS-188 & mdl & $\mathrm{P}$ & 52.96 & 1.30 & 18.56 & 8.07 & 0.14 & 4.30 & 9.45 & 3.68 & 0.79 & 0.34 & 0.04 & 98.73 \\
\hline TS-463 & $\mathrm{mdl}$ & $\mathrm{P}$ & 53.63 & 1.19 & 17.61 & 8.02 & 0.14 & 6.26 & 8.43 & 3.11 & 0.88 & 0.33 & $<0.01$ & 100.10 \\
\hline \multicolumn{15}{|c|}{ Basaltic andesite and basalt of "Egan Cone" } \\
\hline TS-350 & mec & $\mathrm{P}$ & 54.08 & 1.31 & 17.98 & 8.62 & 0.15 & 4.63 & 7.94 & 3.83 & 0.74 & 0.31 & na & 99.54 \\
\hline TS-699 & mec & $\mathrm{P}$ & 53.58 & 1.36 & 18.11 & 8.75 & 0.16 & 4.77 & 8.06 & 3.75 & 0.72 & 0.35 & na & 99.59 \\
\hline TS-707 & mec & $\mathrm{P}$ & 52.91 & 1.51 & 17.83 & 9.18 & 0.16 & 4.93 & 8.09 & 3.81 & 0.73 & 0.45 & na & 99.76 \\
\hline TS-778 & mec & $\mathrm{P}$ & 51.94 & 1.72 & 17.37 & 10.11 & 0.17 & 5.15 & 8.17 & 3.68 & 0.72 & 0.57 & na & 99.59 \\
\hline TS-779 & mec & $\mathrm{P}$ & 51.59 & 1.70 & 17.45 & 10.04 & 0.17 & 5.39 & 8.32 & 3.72 & 0.68 & 0.53 & na & 100.25 \\
\hline TS-780 & mec & $\mathrm{P}$ & 52.17 & 1.70 & 17.49 & 9.99 & 0.18 & 5.11 & 8.03 & 3.66 & 0.71 & 0.56 & na & 99.38 \\
\hline \multicolumn{15}{|c|}{ Basaltic andesite east of Yapoah Lake } \\
\hline TS-593 & mey & NS & 52.80 & 1.28 & 17.61 & 7.98 & 0.14 & 6.41 & 8.58 & 3.65 & 0.85 & 0.30 & na & 98.70 \\
\hline TS-599 & mey & NS & 52.94 & 1.28 & 17.67 & 7.80 & 0.14 & 6.40 & 8.54 & 3.67 & 0.86 & 0.30 & na & 98.37 \\
\hline NS-02-61 & mey & NS & 53.06 & 1.30 & 17.57 & 8.19 & 0.14 & 6.22 & 8.74 & 3.66 & 0.82 & 0.30 & na & 97.60 \\
\hline NS-02-96 & mey & NS & 53.21 & 1.30 & 17.91 & 7.96 & 0.14 & 5.84 & 8.81 & 3.68 & 0.85 & 0.30 & na & 98.96 \\
\hline \multicolumn{15}{|c|}{ Basaltic andesite of fissure vent south of Yapoah Lake } \\
\hline TS-649 & mfy & NS & 57.49 & 1.55 & 16.68 & 8.20 & 0.14 & 3.03 & 6.21 & 4.71 & 1.25 & 0.32 & na & 99.96 \\
\hline TS-758 & mfy & NS & 56.62 & 1.48 & 16.93 & 8.70 & 0.15 & 3.20 & 6.50 & 4.59 & 1.12 & 0.32 & na & 98.61 \\
\hline \multicolumn{15}{|c|}{ Basaltic andesite of Hayden Glacier-Diller Glacier cleaver } \\
\hline TS-178 & mhd & MS & 54.77 & 1.73 & 16.52 & 9.84 & 0.16 & 3.69 & 7.46 & 4.24 & 0.86 & 0.32 & -0.35 & 99.47 \\
\hline TS-179 & mhd & MS & 54.66 & 1.73 & 16.58 & 9.87 & 0.16 & 3.73 & 7.45 & 4.23 & 0.87 & 0.32 & -0.11 & 99.13 \\
\hline TS-180 & mhd & MS & 54.53 & 1.74 & 16.60 & 9.89 & 0.16 & 3.77 & 7.50 & 4.24 & 0.86 & 0.32 & 0.27 & 99.00 \\
\hline TS-477 & mhd & MS & 56.24 & 1.63 & 16.71 & 8.80 & 0.15 & 3.58 & 7.06 & 3.77 & 1.25 & 0.40 & 0.12 & 99.54 \\
\hline \multicolumn{15}{|c|}{ Basaltic andesite of headwaters of Linton Creek } \\
\hline TS-270 & $\mathrm{mhl}$ & MS & 54.55 & 1.72 & 16.62 & 9.84 & 0.16 & 3.77 & 7.54 & 4.23 & 0.84 & 0.33 & -0.21 & 99.51 \\
\hline TS-271 & $\mathrm{mhl}$ & MS & 55.68 & 1.71 & 16.46 & 9.53 & 0.16 & 3.36 & 6.99 & 4.39 & 0.98 & 0.34 & -0.31 & 99.82 \\
\hline \multicolumn{15}{|c|}{ Basaltic andesite of The House Rock } \\
\hline TS-150 & $\mathrm{mhr}$ & $\mathrm{P}$ & 53.36 & 1.08 & 18.52 & 7.81 & 0.13 & 5.57 & 8.45 & 3.66 & 0.72 & 0.30 & -0.13 & 99.50 \\
\hline TS-702 & $\mathrm{mhr}$ & $\mathrm{P}$ & 53.44 & 1.10 & 18.52 & 7.62 & 0.13 & 5.50 & 8.57 & 3.66 & 0.77 & 0.27 & na & 100.05 \\
\hline TS-703 & $\mathrm{mhr}$ & $\mathrm{P}$ & 53.37 & 1.09 & 18.71 & 7.56 & 0.14 & 5.43 & 8.57 & 3.75 & 0.72 & 0.26 & na & 100.09 \\
\hline \multicolumn{15}{|c|}{ Basaltic andesite of Koosah Mountain } \\
\hline TS-351 & $\mathrm{mkm}$ & $\mathrm{P}$ & 54.75 & 1.64 & 17.10 & 8.77 & 0.16 & 4.01 & 7.55 & 4.31 & 0.98 & 0.35 & na & 99.80 \\
\hline TS-352 & $\mathrm{mkm}$ & $\mathrm{P}$ & 53.86 & 1.23 & 17.87 & 7.88 & 0.14 & 5.17 & 8.24 & 3.85 & 0.94 & 0.43 & na & 100.13 \\
\hline TS-564 & $\mathrm{mkm}$ & $\mathrm{P}$ & 52.57 & 1.26 & 17.73 & 8.28 & 0.14 & 6.36 & 8.62 & 3.48 & 0.83 & 0.33 & 0.07 & 98.89 \\
\hline TS-701 & $\mathrm{mkm}$ & $\mathrm{P}$ & 52.80 & 1.22 & 17.53 & 8.06 & 0.14 & 6.51 & 8.63 & 3.53 & 0.85 & 0.32 & na & 99.79 \\
\hline TS-774 & $\mathrm{mkm}$ & $\mathrm{P}$ & 53.33 & 1.23 & 17.69 & 8.07 & 0.14 & 6.36 & 8.12 & 3.53 & 0.80 & 0.32 & na & 98.44 \\
\hline$\underline{\text { TS-775 }}$ & $\mathrm{mkm}$ & $\mathrm{P}$ & 53.08 & 1.19 & 17.35 & 7.95 & 0.14 & 6.75 & 8.54 & 3.45 & 0.83 & 0.31 & na & 99.48 \\
\hline \multicolumn{15}{|c|}{ Basaltic andesite of Little Brother } \\
\hline TS-79 & $\mathrm{mlb}$ & $\mathrm{P}$ & 52.63 & 1.41 & 17.74 & 8.52 & 0.15 & 5.38 & 8.56 & 3.71 & 0.92 & 0.56 & $<0.01$ & 99.35 \\
\hline TS-80 & $\mathrm{mlb}$ & $\mathrm{P}$ & 52.48 & 1.42 & 17.56 & 8.64 & 0.15 & 5.63 & 8.53 & 3.66 & 0.98 & 0.53 & 0.15 & 99.25 \\
\hline TS-81 & $\mathrm{mlb}$ & $\mathrm{P}$ & 52.89 & 1.41 & 17.56 & 8.49 & 0.15 & 5.26 & 8.48 & 3.77 & 1.01 & 0.57 & $<0.01$ & 99.80 \\
\hline TS-383 & $\mathrm{mlb}$ & $\mathrm{P}$ & 53.05 & 1.41 & 17.48 & 8.45 & 0.15 & 5.09 & 8.59 & 3.82 & 1.00 & 0.55 & $<0.01$ & 99.13 \\
\hline TS-385 & $\mathrm{mlb}$ & $\mathrm{P}$ & 52.74 & 1.41 & 17.45 & 8.62 & 0.15 & 5.49 & 8.56 & 3.71 & 0.95 & 0.51 & 0.08 & 99.33 \\
\hline TS-395 & $\mathrm{mlb}$ & $\mathrm{P}$ & 52.97 & 1.40 & 17.46 & 8.45 & 0.15 & 5.23 & 8.61 & 3.77 & 1.01 & 0.54 & $<0.01$ & 99.28 \\
\hline TS-554 & $\mathrm{mlb}$ & $\mathrm{P}$ & 52.60 & 1.43 & 17.10 & 8.63 & 0.15 & 6.15 & 8.49 & 3.63 & 0.99 & 0.43 & $<0.01$ & 99.60 \\
\hline TS-555 & $\mathrm{mlb}$ & $\mathrm{P}$ & 52.24 & 1.46 & 17.38 & 8.77 & 0.16 & 6.03 & 8.54 & 3.60 & 0.94 & 0.48 & $<0.01$ & 99.14 \\
\hline TS-611 & $\mathrm{mlb}$ & $\mathrm{P}$ & 52.30 & 1.42 & 17.86 & 8.50 & 0.15 & 5.66 & 8.55 & 3.76 & 0.92 & 0.48 & na & 98.11 \\
\hline TS-612 & $\mathrm{mlb}$ & $\mathrm{P}$ & 52.89 & 1.42 & 17.52 & 8.39 & 0.15 & 5.48 & 8.54 & 3.79 & 0.96 & 0.47 & na & 100.42 \\
\hline
\end{tabular}




\begin{tabular}{|c|c|c|c|c|c|c|c|c|c|c|c|c|c|c|}
\hline $\mathrm{Ba}$ & Ce & $\mathrm{Cr}$ & Cu & $\mathbf{G a}$ & La & Nb & Nd & $\mathbf{N i}$ & $\mathbf{R b}$ & Sr & $\mathbf{V}$ & $\mathbf{Y}$ & $\mathrm{Zn}$ & $\mathrm{Zr}$ \\
\hline \multicolumn{15}{|c|}{ Basaltic andesite north and south of Demaris Lake } \\
\hline 322 & 36 & 36 & 130 & 19 & 16 & 9 & $<10$ & 21 & 12 & 671 & 208 & 24 & 74 & 127 \\
\hline 350 & 35 & 122 & 59 & 15 & 12 & 8 & $<10$ & 109 & 11 & 614 & 180 & 19 & 67 & 135 \\
\hline \multicolumn{15}{|c|}{ Basaltic andesite and basalt of "Egan Cone" } \\
\hline 346 & 30 & 41 & 53 & 20 & 15 & 6 & 20 & 48 & 11 & 537 & 183 & 25 & 95 & 121 \\
\hline 341 & 31 & 47 & 51 & 20 & 13 & 6 & 20 & 52 & 10 & 535 & 180 & 26 & 99 & 124 \\
\hline 353 & 33 & 54 & 51 & 19 & 14 & 8 & 20 & 56 & 11 & 527 & 187 & 28 & 101 & 133 \\
\hline 359 & 43 & 58 & 48 & 20 & 12 & 10 & 26 & 58 & 11 & 520 & 194 & 34 & 108 & 144 \\
\hline 338 & 38 & 59 & 47 & 20 & 17 & 10 & 25 & 62 & 10 & 505 & 199 & 34 & 104 & 141 \\
\hline 358 & 40 & 59 & 49 & 20 & 15 & 10 & 25 & 57 & 10 & 515 & 189 & 34 & 106 & 147 \\
\hline \multicolumn{15}{|c|}{ Basaltic andesite east of Yapoah Lake } \\
\hline 329 & 32 & 151 & 58 & 19 & 16 & 8 & 20 & 121 & 11 & 546 & 188 & 22 & 80 & 136 \\
\hline 330 & 30 & 151 & 64 & 19 & 13 & 9 & 18 & 120 & 11 & 541 & 190 & 22 & 79 & 137 \\
\hline na & na & na & na & na & na & na & na & na & na & na & na & na & na & na \\
\hline na & na & na & na & na & na & na & na & na & na & na & na & na & na & na \\
\hline \multicolumn{15}{|c|}{ Basaltic andesite of fissure vent south of Yapoah Lake } \\
\hline 436 & 41 & 3 & 50 & 20 & 15 & 8 & 24 & 5 & 20 & 465 & 224 & 27 & 93 & 181 \\
\hline 411 & 39 & 1 & 47 & 21 & 15 & 8 & 21 & 5 & 18 & 536 & 233 & 27 & 93 & 154 \\
\hline \multicolumn{15}{|c|}{ Basaltic andesite of Hayden Glacier-Diller Glacier cleaver } \\
\hline 326 & 26 & 5 & 171 & 21 & 12 & 8 & 20 & 13 & 14 & 513 & 289 & 25 & 93 & 132 \\
\hline 319 & 24 & 8 & 104 & 19 & 9 & 8 & 20 & 16 & 14 & 512 & 289 & 28 & 97 & 137 \\
\hline 339 & 33 & 6 & 107 & 22 & 13 & 7 & $<10$ & 16 & 13 & 516 & 282 & 26 & 93 & 132 \\
\hline 429 & 34 & 26 & 89 & 17 & 9 & 8 & $<10$ & 16 & 22 & 490 & 222 & 27 & 74 & 185 \\
\hline \multicolumn{15}{|c|}{ Basaltic andesite of headwaters of Linton Creek } \\
\hline 321 & 25 & 13 & 108 & 23 & 9 & 7 & 11 & 22 & 12 & 516 & 288 & 25 & 94 & 135 \\
\hline 357 & 28 & $<5$ & 71 & 22 & 13 & 8 & 19 & 20 & 16 & 503 & 260 & 27 & 91 & 146 \\
\hline \multicolumn{15}{|c|}{ Basaltic andesite of The House Rock } \\
\hline na & na & na & na & na & na & na & na & na & na & na & na & na & na & na \\
\hline 321 & 26 & 94 & 48 & 18 & 12 & 7 & 18 & 93 & 12 & 597 & 186 & 20 & 80 & 118 \\
\hline 323 & 29 & 94 & 72 & 18 & 12 & 7 & 18 & 87 & 11 & 598 & 193 & 20 & 82 & 118 \\
\hline \multicolumn{15}{|c|}{ Basaltic andesite of Koosah Mountain } \\
\hline 365 & 31 & 42 & 89 & 21 & 16 & 8 & 21 & 23 & 13 & 511 & 233 & 27 & 90 & 140 \\
\hline 400 & 48 & 98 & 72 & 19 & 22 & 12 & 26 & 68 & 11 & 764 & 168 & 24 & 88 & 179 \\
\hline 368 & 33 & 152 & 59 & 13 & 10 & 9 & 26 & 99 & 12 & 529 & 197 & 20 & 70 & 146 \\
\hline 336 & 33 & 206 & 63 & 18 & 15 & 11 & 20 & 121 & 12 & 518 & 195 & 23 & 81 & 143 \\
\hline 343 & 34 & 204 & 66 & 18 & 12 & 11 & 19 & 120 & 12 & 507 & 168 & 25 & 84 & 141 \\
\hline 339 & 34 & 234 & 62 & 19 & 17 & 11 & 20 & 136 & 12 & 526 & 193 & 25 & 81 & 137 \\
\hline \multicolumn{15}{|c|}{ Basaltic andesite of Little Brother } \\
\hline 414 & 40 & 99 & 49 & 20 & 16 & 16 & 25 & 63 & 13 & 676 & 199 & 28 & 93 & 191 \\
\hline 405 & 37 & 122 & 58 & 21 & 16 & 15 & 19 & 83 & 14 & 664 & 208 & 26 & 99 & 178 \\
\hline 413 & 45 & 97 & 98 & 20 & 20 & 15 & 19 & 62 & 14 & 662 & 203 & 27 & 98 & 190 \\
\hline 420 & 43 & 86 & 58 & 22 & 18 & 20 & 34 & na & 15 & 711 & 242 & 35 & 98 & 239 \\
\hline 408 & 40 & 89 & 51 & 25 & 20 & 19 & 24 & na & 15 & 711 & 217 & 33 & 94 & 224 \\
\hline 411 & 42 & 86 & 72 & 24 & 17 & 19 & 27 & na & 16 & 706 & 232 & 33 & 98 & 236 \\
\hline na & na & na & na & na & na & na & na & na & na & na & na & na & na & na \\
\hline 457 & 45 & 100 & 44 & 16 & 14 & 11 & 15 & 84 & 11 & 671 & 192 & 22 & 79 & 164 \\
\hline 443 & 44 & 96 & 63 & 18 & 23 & 12 & 27 & 66 & 12 & 686 & 194 & 26 & 91 & 170 \\
\hline 434 & 46 & 96 & 50 & 19 & 22 & 12 & 27 & 65 & 13 & 662 & 194 & 27 & 91 & 170 \\
\hline
\end{tabular}


Table 1. Chemical data for Three Sisters volcanic cluster.-Continued

\begin{tabular}{|c|c|c|c|c|c|c|c|c|c|c|c|c|c|c|}
\hline Sample & $\begin{array}{l}\text { Unit } \\
\text { label }\end{array}$ & $\begin{array}{l}\text { Volcanic } \\
\text { group }\end{array}$ & $\mathrm{SiO}_{2}$ & $\mathrm{TiO}_{2}$ & $\mathrm{Al}_{2} \mathrm{O}_{3}$ & $\mathrm{FeO*}$ & MnO & $\mathrm{MgO}$ & $\mathrm{CaO}$ & $\mathrm{Na}_{2} \mathrm{O}$ & $\mathrm{K}_{2} \mathbf{O}$ & $\mathrm{P}_{2} \mathrm{O}_{5}$ & LOI & $\begin{array}{c}\text { Original } \\
\text { total }\end{array}$ \\
\hline \multicolumn{15}{|c|}{ Basaltic andesite of Le Conte Crater } \\
\hline TS-67 & mlc & $\mathrm{P}$ & 54.46 & 1.32 & 16.69 & 8.06 & 0.14 & 6.30 & 7.48 & 3.59 & 1.17 & 0.40 & 0.31 & 99.67 \\
\hline TS-247 & mlc & $\mathrm{P}$ & 54.50 & 1.31 & 16.46 & 8.12 & 0.14 & 6.39 & 7.53 & 3.61 & 1.17 & 0.36 & 0.17 & 99.24 \\
\hline TS-565 & $\mathrm{mlc}$ & $\mathrm{P}$ & 55.85 & 1.30 & 16.29 & 7.69 & 0.14 & 5.79 & 7.15 & 3.70 & 1.39 & 0.30 & 0.44 & 98.44 \\
\hline TS-628 & $\mathrm{mlc}$ & $\mathrm{P}$ & 54.48 & 1.33 & 16.51 & 7.96 & 0.14 & 6.40 & 7.55 & 3.74 & 1.16 & 0.33 & na & 100.50 \\
\hline \multicolumn{15}{|c|}{ Basaltic andesite of Linton Spring } \\
\hline TS-292 & $\mathrm{mls}$ & MS & 55.09 & 1.43 & 17.02 & 9.23 & 0.15 & 3.81 & 7.34 & 4.25 & 0.98 & 0.29 & 0.24 & 98.89 \\
\hline \multicolumn{15}{|c|}{ Basaltic andesite of Millican Crater } \\
\hline TS-745 & $\mathrm{mmc}$ & $\mathrm{P}$ & 53.59 & 1.10 & 18.52 & 7.64 & 0.13 & 5.40 & 8.50 & 3.73 & 0.73 & 0.24 & na & 99.60 \\
\hline$\underline{\mathrm{TS}-745 \mathrm{R}}$ & $\mathrm{mmc}$ & $\mathrm{P}$ & 53.54 & 1.10 & 18.51 & 7.76 & 0.13 & 5.40 & 8.47 & 3.72 & 0.74 & 0.24 & na & 100.60 \\
\hline \multicolumn{15}{|c|}{ Basaltic andesite intrusion of Middle Sister } \\
\hline TS-181 & $\mathrm{mmi}$ & MS & 52.79 & 1.52 & 17.33 & 9.30 & 0.15 & 5.42 & 8.38 & 3.60 & 0.79 & 0.32 & 0.81 & 98.30 \\
\hline TS-474 & $\mathrm{mmi}$ & MS & 53.25 & 1.40 & 17.88 & 8.82 & 0.16 & 5.20 & 8.59 & 3.28 & 0.71 & 0.32 & $<0.01$ & 99.70 \\
\hline \multicolumn{15}{|c|}{ Basaltic andesite of South Matthieu Lake } \\
\hline TS-638 & $\mathrm{mml}$ & NS & 54.82 & 1.51 & 17.09 & 9.31 & 0.16 & 3.84 & 7.39 & 4.22 & 0.97 & 0.28 & na & 99.81 \\
\hline TS-731 & $\mathrm{mml}$ & NS & 54.42 & 1.48 & 17.26 & 9.26 & 0.15 & 3.96 & 7.68 & 4.14 & 0.97 & 0.27 & na & 99.48 \\
\hline TS-737 & $\mathrm{mml}$ & NS & 55.64 & 1.24 & 17.53 & 8.14 & 0.15 & 3.87 & 7.63 & 4.21 & 0.96 & 0.25 & na & 99.53 \\
\hline \multicolumn{15}{|c|}{ Basaltic andesite of Montague Memorial } \\
\hline TS-106 & $\mathrm{mmm}$ & MS & 56.28 & 1.32 & 17.77 & 7.74 & 0.13 & 3.57 & 7.12 & 4.22 & 1.12 & 0.33 & 0.05 & 100.34 \\
\hline TS-384 & $\mathrm{mmm}$ & MS & 56.43 & 1.32 & 17.60 & 7.78 & 0.13 & 3.53 & 7.23 & 4.14 & 1.12 & 0.32 & 0.44 & 98.49 \\
\hline TS-428 & $\mathrm{mmm}$ & MS & 57.27 & 1.32 & 17.73 & 7.61 & 0.13 & 3.10 & 6.79 & 4.07 & 1.26 & 0.32 & $<0.01$ & 100.01 \\
\hline TS-429 & $\mathrm{mmm}$ & MS & 56.62 & 1.34 & 17.43 & 7.79 & 0.13 & 3.42 & 7.08 & 4.33 & 1.16 & 0.30 & 0.11 & 98.86 \\
\hline \multicolumn{15}{|c|}{ Basaltic andesite of North Matthieu Lake } \\
\hline TS-724 & $\mathrm{mmn}$ & NS & 54.58 & 1.51 & 17.08 & 9.33 & 0.15 & 3.89 & 7.59 & 4.25 & 0.94 & 0.28 & na & 100.34 \\
\hline TS-724R & $\mathrm{mmn}$ & NS & 54.60 & 1.51 & 17.10 & 9.29 & 0.15 & 3.90 & 7.57 & 4.26 & 0.93 & 0.27 & na & 100.10 \\
\hline \multicolumn{15}{|c|}{ Basaltic andesite of Middle Sister } \\
\hline TS-3 & $\mathrm{mms}$ & MS & 52.47 & 1.31 & 18.39 & 8.60 & 0.14 & 5.48 & 8.57 & 3.73 & 0.65 & 0.27 & 0.03 & 99.66 \\
\hline TS-4 & $\mathrm{mms}$ & MS & 52.16 & 1.35 & 18.42 & 8.79 & 0.14 & 5.52 & 8.69 & 3.59 & 0.62 & 0.31 & 0.09 & 100.05 \\
\hline TS-8 & $\mathrm{mms}$ & MS & 52.40 & 1.34 & 18.33 & 8.79 & 0.14 & 5.32 & 8.58 & 3.70 & 0.70 & 0.31 & $<0.01$ & 99.99 \\
\hline TS-172 & $\mathrm{mms}$ & MS & 52.54 & 1.30 & 18.15 & 8.74 & 0.14 & 5.66 & 8.66 & 3.56 & 0.62 & 0.23 & -0.25 & 99.34 \\
\hline TS-173 & $\mathrm{mms}$ & MS & 52.49 & 1.32 & 18.20 & 8.79 & 0.14 & 5.66 & 8.64 & 3.48 & 0.63 & 0.24 & -0.04 & 99.04 \\
\hline TS-174 & $\mathrm{mms}$ & MS & 52.91 & 1.37 & 18.01 & 8.75 & 0.14 & 5.28 & 8.44 & 3.70 & 0.72 & 0.28 & -0.23 & 99.02 \\
\hline TS-175 & $\mathrm{mms}$ & MS & 52.70 & 1.37 & 17.87 & 8.87 & 0.14 & 5.56 & 8.53 & 3.59 & 0.68 & 0.28 & -0.05 & 99.21 \\
\hline TS-183 & $\mathrm{mms}$ & MS & 52.65 & 1.31 & 18.05 & 8.76 & 0.14 & 5.74 & 8.54 & 3.51 & 0.66 & 0.24 & 0.09 & 98.76 \\
\hline TS-184 & $\mathrm{mms}$ & MS & 52.62 & 1.32 & 18.01 & 8.83 & 0.14 & 5.65 & 8.60 & 3.55 & 0.64 & 0.24 & -0.35 & 99.57 \\
\hline TS-192 & $\mathrm{mms}$ & MS & 52.76 & 1.37 & 18.42 & 8.57 & 0.14 & 4.92 & 8.77 & 3.67 & 0.70 & 0.28 & -0.15 & 99.50 \\
\hline TS-218 & $\mathrm{mms}$ & MS & 52.50 & 1.33 & 18.06 & 8.83 & 0.14 & 5.68 & 8.61 & 3.57 & 0.64 & 0.24 & -0.33 & 99.79 \\
\hline TS-226 & $\mathrm{mms}$ & MS & 52.52 & 1.38 & 18.14 & 8.79 & 0.14 & 5.41 & 8.69 & 3.58 & 0.68 & 0.27 & 0.03 & 99.38 \\
\hline TS-227 & $\mathrm{mms}$ & MS & 52.62 & 1.34 & 18.34 & 8.62 & 0.14 & 5.31 & 8.69 & 3.57 & 0.70 & 0.26 & -0.04 & 99.37 \\
\hline TS-235 & $\mathrm{mms}$ & MS & 53.44 & 1.42 & 18.41 & 8.40 & 0.14 & 4.26 & 8.73 & 3.73 & 0.79 & 0.27 & -0.11 & 99.53 \\
\hline TS-297 & $\mathrm{mms}$ & MS & 52.23 & 1.41 & 17.84 & 9.16 & 0.15 & 5.73 & 8.58 & 3.58 & 0.64 & 0.26 & -0.04 & 99.35 \\
\hline TS-304B & $\mathrm{mms}$ & MS & 52.56 & 1.88 & 16.85 & 10.32 & 0.17 & 4.61 & 8.07 & 3.84 & 0.89 & 0.40 & 0.03 & 99.30 \\
\hline TS-375 & $\mathrm{mms}$ & MS & 52.75 & 1.30 & 17.95 & 8.75 & 0.14 & 5.67 & 8.59 & 3.54 & 0.64 & 0.28 & $<0.01$ & 99.89 \\
\hline TS-378 & $\mathrm{mms}$ & MS & 52.55 & 1.55 & 17.48 & 9.35 & 0.16 & 5.35 & 8.39 & 3.67 & 0.75 & 0.35 & 0.04 & 99.70 \\
\hline TS-382 & $\mathrm{mms}$ & MS & 52.64 & 1.54 & 17.28 & 9.35 & 0.15 & 5.44 & 8.45 & 3.68 & 0.75 & 0.33 & $<0.01$ & 99.72 \\
\hline TS-398 & $\mathrm{mms}$ & MS & 52.75 & 1.29 & 17.95 & 8.69 & 0.14 & 5.73 & 8.62 & 3.52 & 0.63 & 0.27 & $<0.01$ & 99.31 \\
\hline TS-403 & $\mathrm{mms}$ & MS & 52.60 & 1.28 & 18.20 & 8.46 & 0.14 & 5.50 & 8.92 & 3.58 & 0.62 & 0.29 & $<0.01$ & 99.59 \\
\hline TS-404 & $\mathrm{mms}$ & MS & 52.41 & 1.27 & 18.37 & 8.52 & 0.14 & 5.76 & 8.90 & 3.34 & 0.61 & 0.28 & $<0.01$ & 99.77 \\
\hline TS-406 & $\mathrm{mms}$ & MS & 52.51 & 1.28 & 18.40 & 8.52 & 0.14 & 5.66 & 8.87 & 3.32 & 0.62 & 0.28 & 0.16 & 99.59 \\
\hline
\end{tabular}




\begin{tabular}{|c|c|c|c|c|c|c|c|c|c|c|c|c|c|c|}
\hline $\mathrm{Ba}$ & $\mathrm{Ce}$ & $\mathrm{Cr}$ & $\mathrm{Cu}$ & $\mathbf{G a}$ & La & $\mathrm{Nb}$ & Nd & $\mathbf{N i}$ & $\mathbf{R b}$ & Sr & V & $\mathbf{Y}$ & $\mathrm{Zn}$ & $\mathrm{Zr}$ \\
\hline \multicolumn{15}{|c|}{ Basaltic andesite of Le Conte Crater } \\
\hline 375 & 33 & 204 & 55 & 17 & 16 & 14 & 15 & 128 & 20 & 444 & 180 & 24 & 77 & 165 \\
\hline 374 & 34 & 193 & 56 & 17 & 16 & 13 & 16 & 110 & 21 & 448 & 171 & 23 & 70 & 165 \\
\hline 441 & 33 & 150 & 43 & 13 & 11 & 11 & 28 & 102 & 26 & 417 & 163 & 22 & 62 & 165 \\
\hline 389 & 30 & 205 & 63 & 16 & 18 & 11 & 19 & 124 & 21 & 453 & 172 & 24 & 74 & 159 \\
\hline \multicolumn{15}{|c|}{ Basaltic andesite of Linton Spring } \\
\hline 357 & 29 & 20 & 71 & 20 & 11 & 8 & 19 & 11 & 15 & 552 & 247 & 22 & 94 & 137 \\
\hline \multicolumn{15}{|c|}{ Basaltic andesite of Millican Crater } \\
\hline 312 & 23 & 85 & 65 & 17 & 12 & 7 & 15 & 90 & 12 & 599 & 184 & 20 & 82 & 108 \\
\hline 323 & 26 & 87 & 65 & 19 & 11 & 7 & 14 & 91 & 13 & 605 & 188 & 20 & 80 & 109 \\
\hline \multicolumn{15}{|c|}{ Basaltic andesite intrusion of Middle Sister } \\
\hline 279 & 27 & 88 & 93 & 19 & 10 & 7 & $<10$ & 73 & 12 & 515 & 216 & 25 & 82 & 131 \\
\hline 292 & 26 & 78 & 36 & 16 & 13 & 4 & $<10$ & 55 & 10 & 547 & 210 & 19 & 69 & 110 \\
\hline \multicolumn{15}{|c|}{ Basaltic andesite of South Matthieu Lake } \\
\hline 368 & 32 & 16 & 57 & 21 & 18 & 7 & 19 & 7 & 14 & 547 & 281 & 23 & 91 & 141 \\
\hline 352 & 29 & 23 & 64 & 19 & 11 & 7 & 19 & 11 & 14 & 544 & 280 & 22 & 92 & 134 \\
\hline 362 & 30 & 25 & 102 & 21 & 13 & 6 & 18 & 12 & 14 & 571 & 225 & 22 & 88 & 124 \\
\hline \multicolumn{15}{|c|}{ Basaltic andesite of Montague Memorial } \\
\hline 379 & 31 & 27 & 72 & 20 & 19 & 8 & 18 & 24 & 19 & 492 & 188 & 23 & 73 & 158 \\
\hline 399 & 31 & 15 & 70 & 15 & 13 & 7 & $<10$ & 13 & 17 & 496 & 206 & 22 & 69 & 158 \\
\hline 452 & 34 & 8 & 65 & 17 & 13 & 7 & 11 & 6 & 21 & 492 & 194 & 22 & 66 & 167 \\
\hline 383 & 29 & 22 & 78 & 24 & 12 & 11 & 18 & na & 20 & 521 & 252 & 30 & 76 & 203 \\
\hline \multicolumn{15}{|c|}{ Basaltic andesite of North Matthieu Lake } \\
\hline 358 & 33 & 17 & 60 & 21 & 16 & 8 & 21 & 9 & 14 & 548 & 293 & 22 & 92 & 138 \\
\hline 352 & 30 & 18 & 60 & 20 & 13 & 7 & 18 & 9 & 13 & 539 & 290 & 22 & 93 & 137 \\
\hline \multicolumn{15}{|c|}{ Basaltic andesite of Middle Sister } \\
\hline 242 & 20 & 91 & 85 & 21 & 10 & 6 & $<7$ & 72 & 10 & 550 & 208 & 21 & 83 & 100 \\
\hline 248 & 21 & 100 & 85 & 19 & 10 & 6 & 8 & 76 & 10 & 552 & 208 & 23 & 84 & 110 \\
\hline 252 & 23 & 93 & 87 & 20 & 7 & 6 & 12 & 70 & 10 & 544 & 204 & 22 & 81 & 111 \\
\hline 234 & 19 & 98 & 97 & 19 & 6 & 5 & 11 & 80 & 10 & 577 & 203 & 20 & 77 & 94 \\
\hline 244 & 17 & 103 & 96 & 19 & 7 & 5 & 13 & 82 & 9 & 566 & 208 & 20 & 82 & 97 \\
\hline 266 & 20 & 77 & 88 & 19 & 7 & 7 & $<10$ & 66 & 11 & 557 & 187 & 22 & 74 & 116 \\
\hline 253 & 21 & 96 & 88 & 19 & 9 & 8 & $<10$ & 75 & 12 & 548 & 214 & 24 & 82 & 112 \\
\hline 245 & 21 & 100 & 95 & 21 & 10 & 6 & $<10$ & 76 & 10 & 564 & 207 & 21 & 77 & 97 \\
\hline 239 & 18 & 92 & 98 & 19 & 5 & 5 & 13 & 81 & 9 & 572 & 203 & 20 & 81 & 96 \\
\hline 263 & 26 & 81 & 86 & 20 & 11 & 7 & $<10$ & 59 & 11 & 552 & 196 & 22 & 73 & 114 \\
\hline 237 & 25 & 95 & 102 & 22 & 8 & 5 & $<10$ & 79 & 9 & 572 & 205 & 20 & 79 & 96 \\
\hline 242 & 21 & 92 & 88 & 19 & 6 & 7 & $<10$ & 69 & 11 & 546 & 194 & 23 & 76 & 114 \\
\hline 243 & 22 & 90 & 73 & 19 & 7 & 7 & $<10$ & 69 & 11 & 551 & 193 & 22 & 73 & 110 \\
\hline 275 & 25 & 81 & 99 & 20 & 10 & 7 & $<10$ & 40 & 13 & 551 & 217 & 24 & 73 & 119 \\
\hline 244 & 21 & 84 & 120 & 20 & 9 & 6 & 11 & 77 & 10 & 565 & 212 & 22 & 77 & 105 \\
\hline 338 & 29 & 67 & 115 & 21 & 12 & 10 & 21 & 42 & 14 & 489 & 277 & 34 & 103 & 173 \\
\hline 250 & 22 & 86 & 78 & 13 & 7 & 4 & $<10$ & 69 & 9 & 566 & 237 & 17 & 70 & 95 \\
\hline 284 & 24 & 71 & 82 & 14 & 8 & 5 & $<10$ & 53 & 13 & 526 & 242 & 22 & 74 & 135 \\
\hline 289 & 25 & 71 & 91 & 16 & 10 & 5 & $<10$ & 57 & 11 & 522 & 234 & 23 & 76 & 132 \\
\hline 255 & 13 & 93 & 87 & 17 & 6 & 3 & 12 & 75 & 9 & 576 & 224 & 18 & 122 & 92 \\
\hline 245 & 19 & 89 & 76 & 15 & 9 & 3 & $<10$ & 58 & 10 & 574 & 217 & 17 & 73 & 94 \\
\hline 242 & 13 & 81 & 76 & 16 & $<5$ & 4 & $<10$ & 62 & 8 & 578 & 207 & 17 & 61 & 94 \\
\hline 249 & 23 & 90 & 75 & 14 & 10 & 4 & $<10$ & 64 & 10 & 571 & 215 & 17 & 68 & 95 \\
\hline
\end{tabular}


Table 1. Chemical data for Three Sisters volcanic cluster--Continued

\begin{tabular}{|c|c|c|c|c|c|c|c|c|c|c|c|c|c|c|}
\hline Sample & $\begin{array}{l}\text { Unit } \\
\text { label }\end{array}$ & $\begin{array}{l}\text { Volcanic } \\
\text { group }\end{array}$ & $\mathrm{SiO}_{2}$ & $\mathrm{TiO}_{2}$ & $\mathrm{Al}_{2} \mathrm{O}_{3}$ & $\mathrm{FeO} *$ & MnO & MgO & $\mathrm{CaO}$ & $\mathrm{Na}_{2} \mathrm{O}$ & $\mathrm{K}_{2} \mathrm{O}$ & $\mathrm{P}_{2} \mathrm{O}_{5}$ & LOI & $\begin{array}{c}\text { Original } \\
\text { total }\end{array}$ \\
\hline \multicolumn{15}{|c|}{ Basaltic andesite of Middle Sister-Continued } \\
\hline TS-407 & $\mathrm{mms}$ & MS & 54.10 & 1.40 & 18.17 & 8.34 & 0.14 & 4.23 & 8.49 & 3.55 & 0.87 & 0.31 & $<0.01$ & 99.23 \\
\hline TS-409 & $\mathrm{mms}$ & MS & 53.59 & 1.42 & 18.30 & 8.48 & 0.14 & 4.45 & 8.65 & 3.45 & 0.81 & 0.31 & 0.73 & 98.51 \\
\hline TS-422 & $\mathrm{mms}$ & MS & 52.76 & 1.73 & 17.25 & 9.76 & 0.16 & 4.81 & 8.32 & 3.54 & 0.86 & 0.40 & $<0.01$ & 99.30 \\
\hline TS-465 & $\mathrm{mms}$ & MS & 52.50 & 1.33 & 18.24 & 8.94 & 0.14 & 5.79 & 8.69 & 3.12 & 0.58 & 0.27 & $<0.01$ & 99.41 \\
\hline TS-469 & $\mathrm{mms}$ & MS & 52.77 & 1.32 & 18.09 & 8.85 & 0.14 & 5.70 & 8.64 & 3.18 & 0.64 & 0.28 & $<0.01$ & 99.66 \\
\hline TS-551 & $\mathrm{mms}$ & MS & 52.30 & 1.46 & 17.37 & 8.73 & 0.16 & 5.96 & 8.50 & 3.72 & 0.95 & 0.45 & $<0.01$ & 99.23 \\
\hline TS-304A & $\begin{array}{l}\text { mms } \\
\text { [dike] }\end{array}$ & MS & 53.34 & 1.39 & 18.64 & 8.23 & 0.14 & 4.26 & 8.64 & 3.88 & 0.81 & 0.28 & -0.09 & 99.90 \\
\hline
\end{tabular}

\begin{tabular}{|c|c|c|c|c|c|c|c|c|c|c|c|c|c|c|}
\hline \multicolumn{15}{|c|}{ Pyroxene-bearing variant of the basaltic andesite of Middle Sister } \\
\hline TS-193 & $\mathrm{mms}^{\prime}$ & MS & 54.53 & 1.76 & 16.63 & 9.91 & 0.16 & 3.71 & 7.51 & 4.19 & 0.88 & 0.31 & 0.19 & 98.81 \\
\hline TS-421 & $\mathrm{mms}^{\prime}$ & MS & 54.56 & 1.73 & 16.51 & 9.89 & 0.16 & 3.73 & 7.50 & 4.32 & 0.85 & 0.34 & $<0.01$ & 98.94 \\
\hline TS-423 & mms' & MS & 54.78 & 1.75 & 16.52 & 9.93 & 0.16 & 3.71 & 7.45 & 4.08 & 0.87 & 0.35 & 0.10 & 99.46 \\
\hline TS-424 & $\mathrm{mms}^{\prime}$ & MS & 54.68 & 1.72 & 16.49 & 9.88 & 0.16 & 3.67 & 7.49 & 4.30 & 0.87 & 0.34 & $<0.01$ & 99.09 \\
\hline TS-464 & $\mathrm{mms}^{\prime}$ & MS & 54.91 & 1.74 & 16.63 & 9.94 & 0.16 & 3.73 & 7.41 & 3.85 & 0.87 & 0.35 & $<0.01$ & 99.40 \\
\hline \multicolumn{15}{|c|}{ Basaltic andesite tuff of Middle Sister } \\
\hline TS-266 & $\mathrm{mmt}$ & MS & 51.74 & 1.33 & 19.80 & 8.69 & 0.14 & 5.30 & 8.39 & 3.40 & 0.56 & 0.26 & 2.26 & 97.60 \\
\hline TS-288 & $\mathrm{mmt}$ & MS & 51.98 & 1.49 & 18.93 & 9.26 & 0.15 & 5.07 & 8.21 & 3.55 & 0.68 & 0.29 & 1.71 & 97.35 \\
\hline TS-289 & $\mathrm{mmt}$ & MS & 55.21 & 1.20 & 18.44 & 7.79 & 0.14 & 4.20 & 7.30 & 4.15 & 0.91 & 0.26 & 1.26 & 97.78 \\
\hline \multicolumn{15}{|c|}{ Basaltic andesite of North Fork Whychus Creek } \\
\hline TS-185 & mnf & MS & 53.64 & 1.04 & 18.48 & 7.64 & 0.13 & 5.44 & 8.75 & 3.60 & 0.67 & 0.21 & -0.13 & 99.16 \\
\hline TS-194 & $\mathrm{mnf}$ & MS & 54.35 & 1.03 & 19.09 & 7.23 & 0.12 & 4.62 & 8.52 & 3.73 & 0.70 & 0.21 & 0.23 & 99.14 \\
\hline TS-444 & mnf & MS & 54.23 & 1.07 & 18.58 & 7.45 & 0.13 & 5.03 & 8.58 & 3.48 & 0.76 & 0.29 & 0.17 & 99.72 \\
\hline TS-445 & mnf & MS & 53.78 & 1.10 & 18.26 & 7.64 & 0.13 & 5.56 & 8.71 & 3.35 & 0.76 & 0.30 & 0.11 & 99.26 \\
\hline TS-473 & $\mathrm{mnf}$ & MS & 54.38 & 0.99 & 19.15 & 7.18 & 0.12 & 5.03 & 8.61 & 3.20 & 0.68 & 0.26 & 0.01 & 100.37 \\
\hline \multicolumn{15}{|c|}{ Basaltic andesite north of Hayden Glacier } \\
\hline TS-217 & $\mathrm{mnh}$ & MS & 57.13 & 1.30 & 17.02 & 8.60 & 0.14 & 3.06 & 6.51 & 4.49 & 1.07 & 0.28 & -0.30 & 100.07 \\
\hline TS-470 & $\mathrm{mnh}$ & MS & 54.41 & 1.08 & 18.37 & 7.58 & 0.13 & 5.03 & 8.69 & 3.28 & 0.76 & 0.27 & 0.11 & 99.77 \\
\hline TS-471 & $\mathrm{mnh}$ & MS & 53.44 & 1.06 & 18.84 & 7.62 & 0.13 & 5.37 & 8.98 & 3.27 & 0.63 & 0.25 & 0.06 & 99.90 \\
\hline \multicolumn{15}{|c|}{ Basaltic andesite of North Sister } \\
\hline $\mathrm{TS}-28 \mathrm{~A}$ & $\mathrm{mns}$ & NS & 54.25 & 1.07 & 18.52 & 7.40 & 0.13 & 4.90 & 8.49 & 3.77 & 0.77 & 0.29 & 0.36 & 99.51 \\
\hline TS-28B & $\mathrm{mns}$ & NS & 53.46 & 1.06 & 18.75 & 7.43 & 0.13 & 5.01 & 8.87 & 3.86 & 0.77 & 0.27 & 0.10 & 99.86 \\
\hline TS-29 & $\mathrm{mns}$ & NS & 53.54 & 1.04 & 18.55 & 7.48 & 0.13 & 5.48 & 8.80 & 3.66 & 0.68 & 0.24 & $<0.01$ & 99.89 \\
\hline TS-219 & $\mathrm{mns}$ & NS & 54.32 & 1.04 & 18.85 & 7.26 & 0.12 & 4.77 & 8.65 & 3.64 & 0.74 & 0.23 & 0.57 & 98.83 \\
\hline TS-220 & mns & NS & 53.42 & 1.08 & 18.04 & 7.74 & 0.13 & 6.39 & 8.71 & 3.32 & 0.51 & 0.25 & 1.54 & 97.70 \\
\hline TS-248 & $\mathrm{mns}$ & NS & 54.06 & 1.06 & 18.22 & 7.42 & 0.13 & 5.39 & 8.50 & 3.60 & 0.94 & 0.28 & 0.49 & 98.93 \\
\hline TS-249 & $\mathrm{mns}$ & NS & 54.00 & 1.05 & 18.37 & 7.42 & 0.13 & 5.41 & 8.55 & 3.55 & 0.83 & 0.28 & 0.29 & 99.24 \\
\hline TS-373 & $\mathrm{mns}$ & NS & 53.89 & 1.16 & 19.33 & 7.45 & 0.13 & 3.89 & 8.89 & 3.92 & 0.67 & 0.27 & $<0.01$ & 99.42 \\
\hline TS-388 & $\mathrm{mns}$ & NS & 53.77 & 1.10 & 18.22 & 7.68 & 0.13 & 5.25 & 8.69 & 3.82 & 0.70 & 0.24 & $<0.01$ & 98.92 \\
\hline TS-389 & $\mathrm{mns}$ & NS & 54.00 & 1.16 & 18.58 & 7.46 & 0.13 & 4.64 & 8.71 & 3.98 & 0.73 & 0.21 & na & 99.92 \\
\hline TS-390 & $\mathrm{mns}$ & NS & 53.61 & 1.11 & 19.00 & 7.38 & 0.13 & 4.72 & 8.94 & 3.85 & 0.67 & 0.19 & na & 100.55 \\
\hline TS-391 & $\mathrm{mns}$ & NS & 53.92 & 1.16 & 19.34 & 7.48 & 0.12 & 3.86 & 8.89 & 3.90 & 0.66 & 0.26 & 0.49 & 99.37 \\
\hline TS-594 & $\mathrm{mns}$ & NS & 53.61 & 1.11 & 18.56 & 7.70 & 0.13 & 5.17 & 8.52 & 3.86 & 0.72 & 0.23 & na & 98.59 \\
\hline TS-595 & $\mathrm{mns}$ & NS & 54.13 & 1.08 & 18.26 & 7.28 & 0.13 & 5.36 & 8.66 & 3.71 & 0.76 & 0.23 & na & 99.94 \\
\hline TS-596 & $\mathrm{mns}$ & NS & 53.41 & 1.03 & 18.58 & 7.27 & 0.13 & 5.83 & 8.87 & 3.64 & 0.66 & 0.19 & na & 100.35 \\
\hline TS-600 & $\mathrm{mns}$ & NS & 53.52 & 1.04 & 18.60 & 7.30 & 0.13 & 5.60 & 8.85 & 3.69 & 0.68 & 0.19 & na & 100.04 \\
\hline TS-602 & $\mathrm{mns}$ & NS & 52.51 & 1.21 & 18.44 & 7.96 & 0.14 & 5.78 & 8.85 & 3.81 & 0.65 & 0.26 & na & 100.15 \\
\hline TS-653 & $\mathrm{mns}$ & NS & 54.63 & 0.99 & 18.51 & 7.06 & 0.12 & 5.39 & 8.21 & 3.73 & 0.75 & 0.20 & na & 100.37 \\
\hline TS-654 & mns & NS & 54.39 & 0.98 & 18.36 & 7.19 & 0.12 & 5.69 & 8.19 & 3.74 & 0.74 & 0.21 & na & 99.00 \\
\hline TS-656 & mns & NS & 54.47 & 1.01 & 18.67 & 7.04 & 0.12 & 5.11 & 8.33 & 3.84 & 0.78 & 0.21 & na & 98.41 \\
\hline
\end{tabular}




\begin{tabular}{|c|c|c|c|c|c|c|c|c|c|c|c|c|c|c|}
\hline $\mathrm{Ba}$ & Ce & $\mathrm{Cr}$ & $\mathrm{Cu}$ & $\mathbf{G a}$ & La & $\mathbf{N b}$ & Nd & $\mathbf{N i}$ & $\mathbf{R b}$ & $\mathrm{Sr}$ & $\mathbf{V}$ & $\mathbf{Y}$ & Zn & $\mathrm{Zr}$ \\
\hline \multicolumn{15}{|c|}{ Basaltic andesite of Middle Sister-Continued } \\
\hline 312 & 27 & 62 & 68 & 16 & 12 & 5 & $<10$ & 26 & 14 & 545 & 228 & 20 & 67 & 122 \\
\hline 289 & 24 & $<5$ & 73 & 15 & 8 & 4 & $<10$ & 31 & 12 & 547 & $<5$ & 20 & 67 & 116 \\
\hline 335 & 31 & 46 & 91 & 16 & 11 & 8 & $<10$ & 35 & 13 & 510 & 264 & 26 & 89 & 154 \\
\hline 264 & 17 & 71 & 82 & 14 & 6 & 4 & $<10$ & 75 & 6 & 580 & 210 & 17 & 67 & 93 \\
\hline 254 & 25 & 85 & 86 & 16 & 6 & 4 & $<10$ & 77 & 9 & 571 & 229 & 17 & 78 & 90 \\
\hline 447 & 44 & 104 & 51 & 14 & 11 & 11 & 26 & 74 & 12 & 679 & 179 & 22 & 73 & 163 \\
\hline 286 & 25 & 82 & 92 & 21 & 12 & 6 & 17 & 41 & 13 & 555 & 211 & 24 & 82 & 126 \\
\hline \multicolumn{15}{|c|}{ Pyroxene-bearing variant of the basaltic andesite of Middle Sister } \\
\hline 329 & 30 & 6 & 103 & 20 & 10 & 7 & 13 & 16 & 13 & 511 & 287 & 25 & 98 & 134 \\
\hline 344 & 29 & na & 108 & 23 & 9 & 10 & 21 & na & 13 & 544 & 357 & 31 & 96 & 170 \\
\hline 345 & 25 & $<5$ & 86 & 17 & 9 & 6 & $<10$ & 3 & 15 & 517 & 5 & 9 & 88 & 9 \\
\hline 332 & 27 & $<5$ & 104 & 19 & 9 & 8 & 18 & na & 14 & 540 & 361 & 32 & 107 & 171 \\
\hline 356 & 29 & $<5$ & 148 & 15 & 12 & 4 & 11 & 4 & 13 & 519 & 44 & 22 & 82 & 128 \\
\hline \multicolumn{15}{|c|}{ Basaltic andesite tuff of Middle Sister } \\
\hline 243 & 21 & 98 & 95 & 19 & 8 & 6 & 17 & 70 & 8 & 550 & 192 & 20 & 75 & 99 \\
\hline 404 & 25 & 97 & 92 & 18 & 10 & 8 & 19 & 58 & 11 & 515 & 210 & 24 & 85 & 126 \\
\hline 390 & 25 & 77 & 71 & 17 & 10 & 8 & 12 & 49 & 14 & 506 & 155 & 24 & 86 & 142 \\
\hline \multicolumn{15}{|c|}{ Basaltic andesite of North Fork Whychus Creek } \\
\hline 270 & 25 & 75 & 78 & 20 & 8 & 6 & 15 & 65 & 8 & 578 & 153 & 18 & 68 & 101 \\
\hline 267 & 27 & 45 & 70 & 20 & 11 & 7 & 13 & 60 & 9 & 603 & 147 & 19 & 75 & 114 \\
\hline 309 & 28 & 57 & 67 & 14 & 7 & 5 & $<10$ & 45 & 9 & 582 & 192 & 15 & 64 & 117 \\
\hline 329 & 29 & 73 & 64 & 14 & 7 & 6 & 12 & 58 & 11 & 568 & 179 & 17 & 66 & 124 \\
\hline 280 & 18 & 35 & 52 & 15 & 7 & 4 & $<10$ & 81 & 9 & 614 & 173 & 15 & 59 & 104 \\
\hline \multicolumn{15}{|c|}{ Basaltic andesite north of Hayden Glacier } \\
\hline 408 & 32 & 10 & 65 & 22 & 13 & 8 & 19 & 10 & 17 & 549 & 209 & 23 & 92 & 144 \\
\hline 325 & 27 & 60 & 64 & 14 & 11 & 5 & 19 & 41 & 9 & 566 & 185 & 17 & 62 & 112 \\
\hline 288 & 26 & 33 & 88 & 21 & 30 & 9 & 17 & 94 & 11 & 616 & 228 & 27 & 75 & 106 \\
\hline \multicolumn{15}{|c|}{ Basaltic andesite of North Sister } \\
\hline 287 & 29 & 78 & 70 & 20 & 13 & 8 & 10 & 62 & 10 & 570 & 175 & 18 & 79 & 120 \\
\hline 295 & 26 & 79 & 66 & 20 & 12 & 7 & $<7$ & 54 & 9 & 588 & 176 & 19 & 74 & 119 \\
\hline 268 & 22 & 91 & 76 & 20 & 10 & 6 & 7 & 67 & 8 & 577 & 176 & 18 & 72 & 104 \\
\hline 274 & 25 & 63 & 74 & 20 & 10 & 7 & $<10$ & 64 & 10 & 595 & 159 & 19 & 71 & 117 \\
\hline 289 & 30 & 152 & 55 & 19 & 11 & 8 & 16 & 148 & 6 & 537 & 134 & 20 & 74 & 123 \\
\hline 342 & 31 & 90 & 80 & 19 & 11 & 8 & 17 & 71 & 13 & 614 & 178 & 20 & 76 & 134 \\
\hline 333 & 29 & 89 & 73 & 19 & 11 & 8 & 16 & 80 & 12 & 620 & 171 & 21 & 76 & 135 \\
\hline 262 & 24 & 7 & 68 & 14 & 8 & 4 & $<10$ & 22 & 6 & 623 & 213 & 17 & 62 & 103 \\
\hline 268 & 24 & 69 & 94 & 21 & 7 & 8 & $<10$ & na & 9 & 618 & 237 & 24 & 82 & 138 \\
\hline 280 & 23 & 38 & 89 & 20 & 11 & 6 & 15 & 48 & 9 & 592 & 210 & 20 & 78 & 106 \\
\hline 256 & 19 & 43 & 87 & 19 & 11 & 4 & 13 & 53 & 8 & 609 & 207 & 19 & 74 & 98 \\
\hline 269 & 24 & 5 & 81 & 17 & 8 & 4 & $<10$ & 23 & 6 & 624 & 209 & 16 & 67 & 99 \\
\hline 319 & 21 & 42 & 68 & 19 & 11 & 5 & 16 & 74 & 11 & 595 & 190 & 19 & 78 & 99 \\
\hline 321 & 31 & 98 & 55 & 17 & 13 & 6 & 16 & 66 & 11 & 567 & 190 & 20 & 75 & 119 \\
\hline 274 & 19 & 104 & 70 & 19 & 13 & 5 & 13 & 97 & 8 & 580 & 192 & 18 & 72 & 99 \\
\hline 280 & 22 & 97 & 79 & 19 & 10 & 5 & 17 & 85 & 8 & 583 & 194 & 19 & 73 & 101 \\
\hline 285 & 26 & 46 & 84 & 20 & 12 & 6 & 17 & 92 & 8 & 594 & 199 & 20 & 77 & 117 \\
\hline 299 & 25 & 100 & 33 & 19 & 15 & 6 & 16 & 95 & 9 & 618 & 176 & 18 & 73 & 111 \\
\hline 288 & 32 & 122 & 62 & 18 & 13 & 5 & 17 & 102 & 9 & 607 & 170 & 17 & 70 & 107 \\
\hline 299 & 25 & 68 & 59 & 18 & 13 & 4 & 14 & 83 & 10 & 617 & 176 & 17 & 73 & 109 \\
\hline
\end{tabular}


Table 1. Chemical data for Three Sisters volcanic cluster.-Continued

\begin{tabular}{|c|c|c|c|c|c|c|c|c|c|c|c|c|c|c|}
\hline Sample & $\begin{array}{l}\text { Unit } \\
\text { label }\end{array}$ & $\begin{array}{l}\text { Volcanic } \\
\text { group }\end{array}$ & $\mathrm{SiO}_{2}$ & $\mathrm{TiO}_{2}$ & $\mathrm{Al}_{2} \mathrm{O}_{3}$ & $\mathrm{Fe} 0 *$ & MnO & MgO & $\mathrm{CaO}$ & $\mathrm{Na}_{2} \mathrm{O}$ & $\mathrm{K}_{2} \mathrm{O}$ & $\mathbf{P}_{2} \mathbf{O}_{5}$ & LOI & $\begin{array}{c}\text { Original } \\
\text { total }\end{array}$ \\
\hline \multicolumn{15}{|c|}{ Basaltic andesite of North Sister-Continued } \\
\hline TS-657 & $\mathrm{mns}$ & NS & 54.86 & 1.02 & 18.47 & 7.04 & 0.12 & 4.98 & 8.29 & 3.82 & 0.79 & 0.22 & na & 100.42 \\
\hline TS-658 & mns & NS & 54.17 & 1.03 & 18.49 & 7.14 & 0.13 & 5.42 & 8.54 & 3.63 & 0.81 & 0.24 & na & 99.68 \\
\hline TS-752 & mns & NS & 54.44 & 0.99 & 18.58 & 7.09 & 0.12 & 5.28 & 8.40 & 3.76 & 0.73 & 0.20 & na & 99.29 \\
\hline TS-753 & $\mathrm{mns}$ & NS & 54.51 & 1.01 & 18.68 & 7.09 & 0.12 & 5.05 & 8.40 & 3.78 & 0.74 & 0.21 & na & 98.89 \\
\hline TS-755 & $\mathrm{mns}$ & NS & 54.51 & 0.97 & 18.34 & 7.22 & 0.12 & 5.65 & 8.20 & 3.65 & 0.73 & 0.20 & na & 99.06 \\
\hline TS-761 & $\mathrm{mns}$ & NS & 54.46 & 1.00 & 18.56 & 7.16 & 0.12 & 5.24 & 8.36 & 3.75 & 0.74 & 0.21 & na & 98.91 \\
\hline TS-768 & $\mathrm{mns}$ & NS & 54.45 & 1.01 & 18.46 & 7.06 & 0.12 & 5.35 & 8.40 & 3.71 & 0.80 & 0.22 & na & 99.68 \\
\hline TS-768R & $\mathrm{mns}$ & NS & 54.35 & 1.00 & 18.40 & 7.29 & 0.12 & 5.32 & 8.38 & 3.71 & 0.80 & 0.22 & na & 100.59 \\
\hline NS-07-201 & $\mathrm{mns}$ & NS & 54.10 & 1.10 & 18.36 & 7.51 & 0.13 & 5.35 & 8.27 & 3.72 & 0.80 & 0.25 & na & 99.97 \\
\hline NS-07-203 & $\mathrm{mns}$ & NS & 54.67 & 1.00 & 18.55 & 7.02 & 0.12 & 5.12 & 8.37 & 3.78 & 0.76 & 0.20 & na & 100.38 \\
\hline NS-07-204 & $\mathrm{mns}$ & NS & 53.73 & 1.11 & 18.53 & 7.69 & 0.13 & 5.16 & 8.50 & 3.84 & 0.68 & 0.22 & na & 100.71 \\
\hline TS-433 & $\mathrm{mns}^{\prime}$ & NS & 54.75 & 1.31 & 17.48 & 7.52 & 0.13 & 5.45 & 8.05 & 3.48 & 1.07 & 0.36 & 0.26 & 99.15 \\
\hline TS-435 & $\mathrm{mns}^{\prime}$ & NS & 54.40 & 1.27 & 17.73 & 7.64 & 0.13 & 5.37 & 8.26 & 3.49 & 0.99 & 0.33 & 0.05 & 99.97 \\
\hline TS-436 & $\mathrm{mns}^{\prime}$ & NS & 54.61 & 1.32 & 17.30 & 7.56 & 0.13 & 5.45 & 8.32 & 3.50 & 1.06 & 0.35 & $<0.01$ & 99.59 \\
\hline TS-437 & mns' & NS & 54.53 & 1.32 & 17.47 & 7.55 & 0.13 & 5.55 & 8.19 & 3.43 & 1.06 & 0.36 & 0.14 & 99.19 \\
\hline TS-443 & mns' & NS & 53.07 & 1.20 & 17.72 & 8.11 & 0.14 & 6.48 & 8.48 & 3.25 & 0.80 & 0.33 & $<0.01$ & 99.46 \\
\hline TS-467 & $\mathrm{mns}$ & NS & 53.31 & 1.00 & 18.83 & 7.49 & 0.13 & 5.83 & 9.01 & 3.16 & 0.61 & 0.24 & $<0.01$ & 99.96 \\
\hline TS-468 & $\mathrm{mns}$ & NS & 53.35 & 1.01 & 18.81 & 7.52 & 0.13 & 5.76 & 8.98 & 3.15 & 0.64 & 0.26 & $<0.01$ & 100.08 \\
\hline TS-505 & $\mathrm{mns}^{\prime}$ & NS & 55.09 & 1.31 & 17.14 & 7.46 & 0.13 & 5.50 & 8.20 & 3.31 & 1.10 & 0.37 & $<0.01$ & 100.53 \\
\hline TS-561 & $\mathrm{mns}^{\prime}$ & NS & 55.02 & 1.32 & 17.04 & 7.46 & 0.14 & 5.33 & 7.99 & 3.83 & 1.15 & 0.31 & 0.02 & 99.37 \\
\hline
\end{tabular}

Basaltic andesite north of Trout Creek

\begin{tabular}{lllllllllllllll}
\hline TS-637 & mnt & NS & 56.85 & 1.59 & 16.63 & 8.53 & 0.15 & 3.23 & 6.43 & 4.59 & 1.27 & 0.33 & na & 98.43 \\
TS-663 & mnt & NS & 55.51 & 1.43 & 17.19 & 8.40 & 0.15 & 3.97 & 7.36 & 4.19 & 1.11 & 0.28 & na & 98.97 \\
TS-664 & mnt & NS & 55.66 & 1.42 & 17.13 & 8.26 & 0.15 & 3.98 & 7.37 & 4.32 & 1.02 & 0.28 & na & 99.10 \\
TS-670 & mnt & NS & 55.31 & 1.37 & 17.28 & 8.17 & 0.15 & 4.26 & 7.63 & 4.26 & 0.91 & 0.27 & na & 100.66 \\
NS-07-200 & mnt & NS & 54.94 & 1.41 & 17.43 & 8.42 & 0.15 & 4.26 & 7.61 & 4.21 & 0.88 & 0.28 & na & 98.19 \\
\hline
\end{tabular}

Basaltic andesite of Park Meadow

\begin{tabular}{lllllllllllrrrrr}
\hline TS-516 & $\mathrm{mpm}$ & $\mathrm{P}$ & 55.90 & 0.93 & 17.93 & 7.21 & 0.12 & 4.93 & 8.02 & 3.41 & 0.89 & 0.26 & 0.28 & 99.42 \\
EMT-363 & $\mathrm{mpm}$ & $\mathrm{P}$ & 56.00 & 0.90 & 17.60 & 7.20 & na & 4.70 & 7.90 & 4.20 & 0.80 & na & na & 99.30 \\
EMT-364 & $\mathrm{mpm}$ & $\mathrm{P}$ & 55.50 & 0.95 & 17.30 & 7.30 & na & 5.70 & 8.40 & 3.80 & 0.80 & na & na & 99.75 \\
\hline
\end{tabular}

\begin{tabular}{|c|c|c|c|c|c|c|c|c|c|c|c|c|c|c|}
\hline \multicolumn{15}{|c|}{ Basaltic andesite north of Scott Pass } \\
\hline TS-639 & mpn & NS & 54.56 & 1.48 & 17.18 & 9.25 & 0.15 & 3.98 & 7.66 & 4.16 & 0.91 & 0.27 & na & 99.84 \\
\hline TS-725 & mpn & NS & 54.80 & 1.52 & 17.13 & 9.32 & 0.16 & 3.80 & 7.34 & 4.27 & 0.98 & 0.28 & na & 99.51 \\
\hline TS-726 & mpn & NS & 55.22 & 1.54 & 17.07 & 9.20 & 0.16 & 3.63 & 7.15 & 4.32 & 1.00 & 0.30 & na & 99.57 \\
\hline TS-728 & $\mathrm{mpn}$ & NS & 55.08 & 1.54 & 16.93 & 9.42 & 0.16 & 3.71 & 7.22 & 4.27 & 1.00 & 0.29 & na & 99.19 \\
\hline \multicolumn{15}{|c|}{ Basaltic andesite south of Scott Pass } \\
\hline $\mathrm{TS}-82$ & mps & NS & 55.97 & 1.25 & 17.29 & 8.35 & 0.14 & 3.76 & 7.33 & 4.24 & 0.96 & 0.33 & $<0.01$ & 99.66 \\
\hline TS-83 & mps & NS & 57.59 & 1.42 & 17.03 & 8.08 & 0.14 & 2.94 & 6.05 & 4.71 & 1.23 & 0.41 & 0.10 & 99.44 \\
\hline TS-84A & mps & NS & 58.69 & 1.37 & 16.91 & 7.56 & 0.14 & 2.68 & 5.64 & 4.86 & 1.32 & 0.42 & $<0.01$ & 100.12 \\
\hline TS-84B & mps & NS & 57.65 & 1.42 & 16.92 & 8.14 & 0.15 & 2.95 & 6.08 & 4.66 & 1.23 & 0.40 & $<0.01$ & 99.51 \\
\hline TS-85 & $\mathrm{mps}$ & NS & 56.57 & 1.46 & 16.89 & 8.83 & 0.15 & 3.22 & 6.42 & 4.52 & 1.16 & 0.39 & 0.10 & 99.65 \\
\hline TS-86 & $\mathrm{mps}$ & NS & 56.14 & 1.49 & 16.98 & 9.01 & 0.15 & 3.33 & 6.59 & 4.43 & 1.10 & 0.38 & $<0.01$ & 99.70 \\
\hline TS-87 & $\mathrm{mps}$ & NS & 56.44 & 1.47 & 16.95 & 8.87 & 0.15 & 3.25 & 6.50 & 4.49 & 1.11 & 0.38 & $<0.01$ & 99.89 \\
\hline TS-88 & $\mathrm{mps}$ & NS & 56.37 & 1.48 & 16.99 & 8.89 & 0.15 & 3.26 & 6.47 & 4.50 & 1.11 & 0.38 & $<0.01$ & 99.65 \\
\hline TS-640 & $\mathrm{mps}$ & NS & 56.25 & 1.50 & 16.85 & 8.88 & 0.15 & 3.34 & 6.69 & 4.54 & 1.09 & 0.31 & na & 99.83 \\
\hline TS-648 & mps & NS & 57.41 & 1.63 & 16.39 & 8.56 & 0.15 & 2.96 & 6.13 & 4.67 & 1.36 & 0.34 & na & 99.84 \\
\hline TS-732 & $\mathrm{mps}$ & NS & 56.06 & 1.49 & 16.99 & 8.87 & 0.15 & 3.34 & 6.73 & 4.58 & 1.09 & 0.30 & na & 99.71 \\
\hline TS-733 & $\mathrm{mps}$ & NS & 55.95 & 1.49 & 17.05 & 8.94 & 0.15 & 3.34 & 6.79 & 4.50 & 1.08 & 0.30 & na & 99.10 \\
\hline TS-738 & $\mathrm{mps}$ & NS & 56.29 & 1.54 & 16.88 & 8.59 & 0.15 & 3.43 & 6.74 & 4.51 & 1.16 & 0.32 & na & 99.84 \\
\hline TS-740 & $\mathrm{mps}$ & NS & 57.13 & 1.63 & 16.58 & 8.62 & 0.15 & 2.99 & 6.10 & 4.71 & 1.34 & 0.34 & na & 99.78 \\
\hline
\end{tabular}




\begin{tabular}{|c|c|c|c|c|c|c|c|c|c|c|c|c|c|c|}
\hline $\mathrm{Ba}$ & $\mathrm{Ce}$ & $\mathrm{Cr}$ & $\mathrm{Cu}$ & $\mathbf{G a}$ & La & Nb & Nd & $\mathbf{N i}$ & $\mathbf{R b}$ & Sr & $\mathbf{V}$ & $Y$ & $\mathrm{Zn}$ & $\mathrm{Zr}$ \\
\hline \multicolumn{15}{|c|}{ Basaltic andesite of North Sister-Continued } \\
\hline 311 & 26 & 67 & 46 & 18 & 13 & 5 & 16 & 80 & 11 & 627 & 179 & 17 & 75 & 115 \\
\hline 344 & 30 & 94 & 63 & 18 & 14 & 6 & 19 & 75 & 11 & 619 & 175 & 20 & 76 & 126 \\
\hline 289 & 27 & 81 & 63 & 18 & 13 & 6 & 15 & 99 & 11 & 627 & 172 & 17 & 74 & 106 \\
\hline 304 & 30 & 71 & 63 & 20 & 14 & 6 & 16 & 82 & 11 & 631 & 173 & 18 & 73 & 111 \\
\hline 283 & 29 & 123 & 43 & 18 & 12 & 6 & 16 & 106 & 9 & 613 & 169 & 18 & 74 & 107 \\
\hline 290 & 24 & 78 & 63 & 19 & 11 & 6 & 13 & 96 & 9 & 625 & 171 & 19 & 73 & 107 \\
\hline 310 & 33 & 80 & 70 & 20 & 11 & 7 & 17 & 102 & 11 & 632 & 176 & 19 & 74 & 112 \\
\hline 311 & 31 & 79 & 69 & 20 & 13 & 7 & 17 & 101 & 12 & 634 & 176 & 19 & 76 & 114 \\
\hline 342 & 25 & 93 & 50 & 17 & 15 & 7 & 15 & 84 & 14 & 578 & 185 & 19 & 80 & 121 \\
\hline 305 & 28 & 72 & 41 & 17 & 14 & 6 & 16 & 85 & 9 & 631 & 177 & 17 & 74 & 112 \\
\hline 313 & 20 & 41 & 66 & 20 & 10 & 5 & 13 & 76 & 11 & 608 & 191 & 19 & 79 & 101 \\
\hline 423 & 38 & 104 & 59 & 15 & 9 & 10 & 17 & 40 & 15 & 688 & 180 & 19 & 63 & 151 \\
\hline 387 & 32 & 83 & 47 & 16 & 14 & 9 & $<10$ & 43 & 14 & 679 & 179 & 17 & 63 & 127 \\
\hline 414 & 33 & 86 & 26 & 15 & 10 & 10 & 22 & 37 & 16 & 684 & 187 & 17 & 59 & 135 \\
\hline 419 & 36 & 97 & 42 & 14 & 12 & 10 & $<10$ & 45 & 15 & 685 & 179 & 18 & 65 & 146 \\
\hline 341 & 30 & 116 & 58 & 14 & 9 & 6 & $<10$ & 107 & 10 & 604 & 169 & 17 & 65 & 128 \\
\hline 271 & 22 & 74 & 65 & 15 & 7 & 3 & $<10$ & 89 & 5 & 607 & 163 & 14 & 57 & 90 \\
\hline 269 & 25 & 79 & 64 & 16 & 8 & 4 & $<10$ & 90 & 7 & 598 & 195 & 14 & 62 & 92 \\
\hline 408 & 40 & 92 & 44 & 14 & 16 & 11 & $<10$ & 44 & 15 & 684 & 172 & 18 & 63 & 146 \\
\hline 422 & 38 & 89 & 47 & 15 & 15 & 11 & 10 & 51 & 18 & 663 & 179 & 17 & 64 & 142 \\
\hline \multicolumn{15}{|c|}{ Basaltic andesite north of Trout Creek } \\
\hline 421 & 34 & 4 & 54 & 21 & 18 & 8 & 22 & 8 & 21 & 447 & 232 & 28 & 93 & 181 \\
\hline 345 & 35 & 17 & 68 & 20 & 14 & 8 & 20 & 14 & 15 & 486 & 219 & 25 & 89 & 150 \\
\hline 340 & 28 & 17 & 70 & 19 & 15 & 7 & 17 & 14 & 15 & 487 & 220 & 25 & 87 & 149 \\
\hline 326 & 33 & 28 & 68 & 19 & 12 & 7 & 20 & 18 & 13 & 504 & 220 & 23 & 85 & 142 \\
\hline 345 & 26 & 21 & 80 & 20 & 14 & 8 & 15 & 16 & 12 & 505 & 220 & 25 & 84 & 144 \\
\hline \multicolumn{15}{|c|}{ Basaltic andesite of Park Meadow } \\
\hline na & na & na & na & na & na & na & na & na & na & na & na & na & na & na \\
\hline na & na & na & na & na & na & na & na & na & na & na & na & na & na & na \\
\hline na & na & na & na & na & na & na & na & na & na & na & na & na & na & na \\
\hline \multicolumn{15}{|c|}{ Basaltic andesite north of Scott Pass } \\
\hline 350 & 31 & 23 & 64 & 20 & 13 & 7 & 21 & 8 & 14 & 554 & 287 & 22 & 90 & 133 \\
\hline 370 & 30 & 16 & 59 & 19 & 16 & 8 & 21 & 8 & 14 & 536 & 284 & 24 & 93 & 140 \\
\hline 389 & 36 & 11 & 46 & 20 & 14 & 8 & 21 & 4 & 15 & 529 & 258 & 24 & 97 & 149 \\
\hline 375 & 35 & 11 & 50 & 20 & 12 & 7 & 19 & 5 & 14 & 528 & 258 & 23 & 98 & 145 \\
\hline \multicolumn{15}{|c|}{ Basaltic andesite south of Scott Pass } \\
\hline 367 & 25 & 21 & 88 & 19 & 11 & 7 & 15 & 18 & 15 & 569 & 223 & 21 & 88 & 134 \\
\hline 435 & 34 & $<3$ & 33 & 18 & 15 & 8 & 17 & 11 & 19 & 527 & 191 & 26 & 98 & 178 \\
\hline 456 & 33 & $<3$ & 32 & 21 & 15 & 10 & 23 & 10 & 20 & 507 & 149 & 28 & 92 & 193 \\
\hline 430 & 37 & $<3$ & 36 & 25 & 17 & 9 & 22 & 12 & 18 & 527 & 184 & 26 & 97 & 179 \\
\hline 406 & 33 & $<3$ & 53 & 21 & 13 & 9 & 23 & 12 & 17 & 538 & 216 & 26 & 97 & 166 \\
\hline 401 & 34 & $<3$ & 68 & 22 & 16 & 9 & 17 & 12 & 17 & 544 & 232 & 25 & 95 & 159 \\
\hline 399 & 30 & $<3$ & 50 & 21 & 14 & 9 & 13 & 12 & 17 & 541 & 233 & 26 & 99 & 162 \\
\hline 403 & 33 & $<3$ & 52 & 24 & 14 & 9 & 20 & 12 & 17 & 538 & 241 & 26 & 93 & 159 \\
\hline 415 & 34 & 2 & 56 & 21 & 17 & 7 & 19 & 2 & 16 & 539 & 261 & 24 & 91 & 150 \\
\hline 457 & 40 & 1 & 54 & 21 & 18 & 9 & 24 & 5 & 23 & 440 & 230 & 30 & 94 & 195 \\
\hline 402 & 29 & 2 & 54 & 20 & 14 & 7 & 19 & 3 & 15 & 533 & 257 & 24 & 94 & 150 \\
\hline 401 & 39 & 3 & 61 & 20 & 15 & 7 & 22 & 4 & 16 & 533 & 259 & 24 & 93 & 148 \\
\hline 399 & 35 & 7 & 52 & 20 & 16 & 9 & 22 & 12 & 18 & 465 & 228 & 28 & 93 & 174 \\
\hline 450 & 38 & 1 & 49 & 21 & 18 & 10 & 25 & 8 & 21 & 431 & 227 & 29 & 101 & 196 \\
\hline
\end{tabular}


Table 1. Chemical data for Three Sisters volcanic cluster.-Continued

\begin{tabular}{|c|c|c|c|c|c|c|c|c|c|c|c|c|c|c|}
\hline Sample & $\begin{array}{l}\text { Unit } \\
\text { label }\end{array}$ & $\begin{array}{l}\text { Volcanic } \\
\text { group }\end{array}$ & $\mathrm{SiO}_{2}$ & $\mathrm{TiO}_{2}$ & $\mathrm{Al}_{2} \mathrm{O}_{3}$ & $\mathrm{FeO} *$ & MnO & MgO & $\mathrm{CaO}$ & $\mathrm{Na}_{2} \mathrm{O}$ & $\mathrm{K}_{2} \mathrm{O}$ & $\mathrm{P}_{2} \mathrm{O}_{5}$ & LOI & $\begin{array}{c}\text { Original } \\
\text { total }\end{array}$ \\
\hline \multicolumn{15}{|c|}{ Basaltic andesite south of Scott Pass - Continued } \\
\hline TS-742 & mps & NS & 56.15 & 1.49 & 16.98 & 8.80 & 0.15 & 3.30 & 6.67 & 4.65 & 1.11 & 0.31 & na & 100.77 \\
\hline TS-762 & $\mathrm{mps}$ & NS & 57.34 & 1.64 & 16.55 & 8.50 & 0.15 & 2.97 & 6.11 & 4.67 & 1.32 & 0.35 & na & 99.35 \\
\hline \multicolumn{15}{|c|}{ Basaltic andesite of Renfrew Glacier } \\
\hline TS-105 & $\mathrm{mrg}$ & MS & 54.55 & 1.73 & 16.69 & 9.82 & 0.16 & 3.75 & 7.40 & 4.27 & 0.86 & 0.38 & $<0.01$ & 99.69 \\
\hline TS-379 & $\mathrm{mrg}$ & MS & 54.56 & 1.77 & 16.58 & 9.97 & 0.16 & 3.70 & 7.53 & 4.17 & 0.81 & 0.36 & 0.10 & 99.13 \\
\hline TS-381 & $\mathrm{mrg}$ & MS & 54.64 & 1.73 & 16.47 & 9.87 & 0.16 & 3.75 & 7.45 & 4.32 & 0.87 & 0.34 & $<0.01$ & 99.17 \\
\hline TS-402 & $\mathrm{mrg}$ & MS & 54.71 & 1.72 & 16.36 & 9.86 & 0.16 & 3.83 & 7.49 & 4.24 & 0.87 & 0.36 & $<0.01$ & 99.23 \\
\hline TS-417 & $\mathrm{mrg}$ & MS & 54.83 & 1.73 & 16.61 & 9.92 & 0.17 & 3.61 & 7.37 & 4.11 & 0.88 & 0.35 & $<0.01$ & 99.54 \\
\hline \multicolumn{15}{|c|}{ Basaltic andesite of Sims Butte } \\
\hline TS-634 & $\mathrm{msb}$ & $\mathrm{P}$ & 52.80 & 1.30 & 17.29 & 8.29 & 0.14 & 6.87 & 8.33 & 3.54 & 0.78 & 0.26 & na & 99.94 \\
\hline TS-667 & $\mathrm{msb}$ & $\mathrm{P}$ & 54.66 & 1.20 & 17.23 & 7.54 & 0.14 & 6.13 & 7.71 & 3.73 & 1.03 & 0.23 & na & 99.06 \\
\hline TS-747 & $\mathrm{msb}$ & $\mathrm{P}$ & 56.59 & 1.09 & 16.83 & 7.14 & 0.13 & 5.52 & 7.11 & 3.69 & 1.29 & 0.21 & na & 98.72 \\
\hline TS-748 & $\mathrm{msb}$ & $\mathrm{P}$ & 54.28 & 1.21 & 17.08 & 7.88 & 0.14 & 6.43 & 7.76 & 3.59 & 0.97 & 0.25 & na & 98.70 \\
\hline TS-749 & msb & $\mathrm{P}$ & 54.24 & 1.24 & 17.06 & 8.06 & 0.14 & 6.40 & 7.69 & 3.57 & 0.96 & 0.24 & na & 98.84 \\
\hline TS-750 & msb & $\mathrm{P}$ & 52.74 & 1.30 & 17.26 & 8.37 & 0.14 & 6.87 & 8.28 & 3.60 & 0.79 & 0.26 & na & 99.10 \\
\hline TS-751 & $\mathrm{msb}$ & $\mathrm{P}$ & 52.35 & 1.31 & 17.52 & 8.41 & 0.15 & 6.98 & 8.44 & 3.48 & 0.70 & 0.26 & na & 98.35 \\
\hline CR-111 & $\mathrm{msb}$ & $\mathrm{P}$ & 54.02 & 1.22 & 16.81 & 8.19 & 0.13 & 6.51 & 7.93 & 3.58 & 0.96 & 0.25 & 0.00 & 100.12 \\
\hline \multicolumn{15}{|c|}{ Basaltic andesite of Separation Creek } \\
\hline TS-113 & $\mathrm{msc}$ & $\mathrm{P}$ & 57.10 & 1.22 & 17.36 & 7.47 & 0.13 & 3.80 & 6.73 & 4.34 & 1.15 & 0.29 & -0.16 & 99.25 \\
\hline TS-114 & $\mathrm{msc}$ & $\mathrm{P}$ & 56.76 & 1.22 & 17.48 & 7.52 & 0.13 & 3.91 & 6.86 & 4.31 & 1.12 & 0.30 & -0.17 & 99.15 \\
\hline TS-127 & $\mathrm{msc}$ & $\mathrm{P}$ & 57.05 & 1.26 & 17.23 & 7.58 & 0.13 & 3.78 & 6.82 & 4.30 & 1.16 & 0.30 & 0.33 & 98.29 \\
\hline TS-255 & $\mathrm{msc}$ & $\mathrm{P}$ & 57.27 & 1.23 & 17.58 & 7.50 & 0.13 & 3.66 & 6.68 & 4.17 & 1.10 & 0.28 & 0.41 & 99.12 \\
\hline TS-290 & $\mathrm{msc}$ & $\mathrm{P}$ & 56.92 & 1.22 & 17.43 & 7.55 & 0.13 & 3.81 & 6.78 & 4.35 & 1.14 & 0.28 & 0.47 & 98.87 \\
\hline TS-309 & $\mathrm{msc}$ & $\mathrm{P}$ & 57.16 & 1.21 & 17.39 & 7.44 & 0.13 & 3.73 & 6.77 & 4.35 & 1.15 & 0.28 & -0.11 & 99.66 \\
\hline TS-310 & $\mathrm{msc}$ & $\mathrm{P}$ & 56.81 & 1.19 & 17.57 & 7.49 & 0.13 & 3.92 & 6.87 & 4.25 & 1.09 & 0.28 & -0.07 & 99.76 \\
\hline TS-311 & $\mathrm{msc}$ & $\mathrm{P}$ & 56.74 & 1.19 & 17.61 & 7.48 & 0.13 & 3.96 & 6.89 & 4.23 & 1.09 & 0.28 & 0.56 & 98.99 \\
\hline TS-320 & msc & $\mathrm{P}$ & 56.91 & 1.22 & 17.53 & 7.60 & 0.13 & 3.74 & 6.78 & 4.27 & 1.12 & 0.29 & 0.20 & 99.40 \\
\hline TS-537 & $\mathrm{msc}$ & $\mathrm{P}$ & 57.09 & 1.23 & 17.38 & 7.48 & 0.13 & 3.76 & 6.82 & 4.26 & 1.17 & 0.27 & 0.42 & 98.58 \\
\hline \multicolumn{15}{|c|}{ Basaltic andesite of South Fork Whychus Creek } \\
\hline TS-190 & $m s f$ & $\mathrm{P}$ & 53.69 & 0.99 & 18.74 & 7.69 & 0.13 & 5.39 & 8.57 & 3.67 & 0.58 & 0.15 & 0.45 & 98.88 \\
\hline TS-191 & msf & $\mathrm{P}$ & 53.97 & 1.02 & 18.63 & 7.66 & 0.13 & 5.10 & 8.56 & 3.78 & 0.60 & 0.15 & -0.03 & 98.91 \\
\hline TS-459 & msf & $\mathrm{P}$ & 53.94 & 1.01 & 18.65 & 7.70 & 0.13 & 5.28 & 8.57 & 3.52 & 0.60 & 0.20 & 0.08 & 99.35 \\
\hline \multicolumn{15}{|c|}{ Basaltic andesite of Soap Creek-North Fork Whychus Creek confluence } \\
\hline TS-466 & $\mathrm{msp}$ & $\mathrm{P}$ & 54.18 & 1.32 & 17.59 & 7.58 & 0.13 & 5.60 & 8.69 & 3.15 & 1.03 & 0.33 & $<0.01$ & 99.09 \\
\hline TS-502 & $\mathrm{msp}$ & $\mathrm{P}$ & 54.77 & 1.26 & 17.60 & 7.56 & 0.13 & 5.30 & 8.29 & 3.37 & 0.99 & 0.33 & $<0.01$ & 100.19 \\
\hline TS-504 & $\mathrm{msp}$ & $\mathrm{P}$ & 54.56 & 1.30 & 17.46 & 7.58 & 0.13 & 5.44 & 8.46 & 3.34 & 1.00 & 0.34 & $<0.01$ & 99.85 \\
\hline \multicolumn{15}{|c|}{ Basaltic andesite of Middle Sister summit } \\
\hline TS-234 & $\mathrm{mss}$ & MS & 56.11 & 1.32 & 17.60 & 7.76 & 0.13 & 3.75 & 7.60 & 3.73 & 1.33 & 0.27 & 0.44 & 99.04 \\
\hline \multicolumn{15}{|c|}{ Basaltic andesite south of Trout Creek } \\
\hline NS-07-202 & mst & NS & 53.34 & 1.16 & 19.86 & 7.49 & 0.13 & 3.99 & 8.59 & 4.09 & 0.72 & 0.23 & na & 99.19 \\
\hline \multicolumn{15}{|c|}{ Basaltic andesite and basalt of Trout Creek Butte } \\
\hline TS-660 & mtb & $\mathrm{P}$ & 51.94 & 1.14 & 17.65 & 8.21 & 0.15 & 6.01 & 10.57 & 3.15 & 0.57 & 0.21 & na & 100.09 \\
\hline TS-660R & $\mathrm{mtb}$ & $\mathrm{P}$ & 51.89 & 1.14 & 17.65 & 8.30 & 0.15 & 5.99 & 10.55 & 3.15 & 0.56 & 0.21 & na & 100.38 \\
\hline TS-661 & $\mathrm{mtb}$ & $\mathrm{P}$ & 51.82 & 1.23 & 17.75 & 8.45 & 0.16 & 5.84 & 10.47 & 3.18 & 0.47 & 0.23 & na & 99.33 \\
\hline TS-662 & $\mathrm{mtb}$ & $\mathrm{P}$ & 52.14 & 1.29 & 17.51 & 8.45 & 0.16 & 5.65 & 10.32 & 3.27 & 0.57 & 0.25 & na & 100.46 \\
\hline CR-115 & mtb & $\mathrm{P}$ & 52.72 & 1.31 & 17.61 & 8.29 & 0.14 & 5.91 & 8.77 & 3.67 & 0.85 & 0.32 & $<0.01$ & 99.56 \\
\hline
\end{tabular}




\begin{tabular}{|c|c|c|c|c|c|c|c|c|c|c|c|c|c|c|}
\hline $\mathbf{B a}$ & Ce & $\mathrm{Cr}$ & Cu & Ga & La & $\mathbf{N b}$ & Nd & $\mathbf{N i}$ & $\mathbf{R b}$ & $\mathrm{Sr}$ & $\mathbf{V}$ & $\mathbf{Y}$ & Zn & $\mathrm{Zr}$ \\
\hline \multicolumn{15}{|c|}{ Basaltic andesite south of Scott Pass_-Continued } \\
\hline 413 & 35 & 3 & 59 & 20 & 15 & 7 & 21 & 4 & 16 & 540 & 256 & 25 & 94 & 152 \\
\hline 450 & 46 & 3 & 52 & 21 & 19 & 11 & 25 & 11 & 22 & 443 & 228 & 32 & 96 & 196 \\
\hline \multicolumn{15}{|c|}{ Basaltic andesite of Renfrew Glacier } \\
\hline 324 & 28 & 7 & 87 & 23 & 13 & 8 & 19 & 19 & 13 & 515 & 257 & 26 & 90 & 133 \\
\hline 363 & 26 & $<5$ & 98 & 18 & 7 & 5 & $<10$ & 3 & 11 & 526 & 303 & 23 & 86 & 136 \\
\hline 324 & 28 & na & 91 & 20 & 13 & 11 & 12 & na & 15 & 545 & 371 & 35 & 97 & 173 \\
\hline 345 & 29 & $<5$ & 88 & 17 & 10 & 5 & 19 & 4 & 13 & 518 & 309 & 23 & 89 & 129 \\
\hline 356 & 26 & $<5$ & 97 & 17 & 11 & 6 & $<10$ & 3 & 12 & 513 & 296 & 23 & 84 & 132 \\
\hline \multicolumn{15}{|c|}{ Basaltic andesite of Sims Butte } \\
\hline 272 & 29 & 215 & 59 & 18 & 16 & 6 & 16 & 121 & 14 & 459 & 188 & 23 & 76 & 128 \\
\hline 315 & 26 & 156 & 45 & 16 & 14 & 6 & 15 & 106 & 19 & 423 & 168 & 22 & 75 & 131 \\
\hline 351 & 29 & 131 & 44 & 17 & 12 & 6 & 16 & 95 & 27 & 403 & 152 & 23 & 67 & 128 \\
\hline 305 & 28 & 190 & 52 & 18 & 10 & 8 & 16 & 120 & 18 & 435 & 170 & 24 & 75 & 131 \\
\hline 307 & 23 & 188 & 55 & 17 & 13 & 8 & 13 & 121 & 18 & 430 & 170 & 24 & 74 & 132 \\
\hline 268 & 26 & 209 & 64 & 18 & 10 & 7 & 15 & 128 & 13 & 456 & 191 & 23 & 78 & 124 \\
\hline 261 & 29 & 212 & 59 & 16 & 8 & 8 & 17 & 130 & 11 & 462 & 189 & 24 & 78 & 125 \\
\hline na & na & na & na & na & na & na & na & na & na & na & na & na & na & na \\
\hline \multicolumn{15}{|c|}{ Basaltic andesite of Separation Creek } \\
\hline na & na & na & na & na & na & na & na & na & na & na & na & na & na & na \\
\hline na & na & na & na & na & na & na & na & na & na & na & na & na & na & na \\
\hline na & na & na & na & na & na & na & na & na & na & na & na & na & na & na \\
\hline 397 & 29 & 42 & 63 & 22 & 12 & 7 & 24 & 31 & 16 & 491 & 164 & 23 & 79 & 162 \\
\hline 375 & 26 & 43 & 58 & 20 & 11 & 7 & 17 & 27 & 19 & 498 & 165 & 23 & 76 & 155 \\
\hline 376 & 26 & 39 & 62 & 19 & 10 & 7 & 17 & 23 & 19 & 501 & 163 & 21 & 79 & 153 \\
\hline 369 & 27 & 47 & 62 & 20 & 15 & 8 & 18 & 24 & 18 & 503 & 160 & 22 & 79 & 146 \\
\hline 359 & 28 & 43 & 42 & 21 & 11 & 7 & 16 & 31 & 18 & 508 & 163 & 21 & 75 & 145 \\
\hline 372 & 27 & 42 & 64 & 22 & 11 & 7 & 20 & 27 & 19 & 504 & 171 & 22 & 86 & 153 \\
\hline 422 & 26 & 27 & 52 & 14 & 13 & 6 & $<10$ & 23 & 18 & 498 & 179 & 20 & 71 & 149 \\
\hline \multicolumn{15}{|c|}{ Basaltic andesite of South Fork Whychus Creek } \\
\hline 217 & 18 & 76 & 89 & 18 & 6 & 4 & $<10$ & 40 & 8 & 589 & 176 & 16 & 75 & 73 \\
\hline 209 & 16 & 68 & 79 & 17 & $<5$ & 5 & 16 & 30 & 7 & 582 & 178 & 18 & 69 & 76 \\
\hline 225 & 11 & 53 & 76 & 15 & 6 & $<2$ & $<10$ & 27 & 5 & 592 & 170 & 13 & 57 & 69 \\
\hline \multicolumn{15}{|c|}{ Basaltic andesite of Soap Creek-North Fork Whychus Creek confluence } \\
\hline 362 & 36 & 92 & 5 & 14 & 14 & 10 & $<10$ & 44 & 17 & 702 & 196 & 17 & 65 & 128 \\
\hline 382 & 33 & 82 & 40 & 14 & 13 & 7 & $<10$ & 41 & 14 & 666 & 170 & 15 & 65 & 123 \\
\hline 372 & 35 & 82 & 43 & 15 & 12 & 9 & $<10$ & 38 & 15 & 687 & 190 & 16 & 61 & 128 \\
\hline \multicolumn{15}{|c|}{ Basaltic andesite of Middle Sister summit } \\
\hline 356 & 29 & 67 & 64 & 21 & 12 & 8 & 18 & 41 & 24 & 496 & 197 & 25 & 77 & 151 \\
\hline \multicolumn{15}{|c|}{ Basaltic andesite south of Trout Creek } \\
\hline 271 & 20 & 15 & 44 & 20 & 11 & 4 & 15 & 41 & 8 & 641 & 190 & 19 & 76 & 105 \\
\hline \multicolumn{15}{|c|}{ Basaltic andesite and basalt of Trout Creek Butte } \\
\hline 231 & 28 & 152 & 44 & 19 & 11 & 5 & 19 & 28 & 6 & 594 & 215 & 22 & 79 & 108 \\
\hline 234 & 24 & 151 & 43 & 18 & 9 & 4 & 16 & 29 & 6 & 598 & 219 & 23 & 78 & 108 \\
\hline 234 & 26 & 146 & 46 & 19 & 13 & 5 & 18 & 28 & 4 & 570 & 212 & 24 & 80 & 118 \\
\hline 247 & 31 & 137 & 40 & 18 & 13 & 6 & 20 & 28 & 5 & 595 & 227 & 24 & 84 & 129 \\
\hline na & na & na & na & na & na & na & na & na & na & na & na & na & na & na \\
\hline
\end{tabular}


Table 1. Chemical data for Three Sisters volcanic cluster--Continued

\begin{tabular}{|c|c|c|c|c|c|c|c|c|c|c|c|c|c|c|}
\hline Sample & $\begin{array}{l}\text { Unit } \\
\text { label }\end{array}$ & $\begin{array}{c}\text { Volcanic } \\
\text { group }\end{array}$ & $\mathrm{SiO}_{2}$ & $\mathrm{TiO}_{2}$ & $\mathrm{Al}_{2} \mathrm{O}_{3}$ & $\mathrm{FeO} *$ & $\mathrm{MnO}$ & $\mathrm{MgO}$ & $\mathrm{CaO}$ & $\mathrm{Na}_{2} \mathrm{O}$ & $\mathrm{K}_{2} \mathrm{O}$ & $\mathrm{P}_{2} \mathrm{O}_{5}$ & LOI & $\begin{array}{c}\text { Original } \\
\text { total }\end{array}$ \\
\hline \multicolumn{15}{|c|}{ Basaltic andesite of The Husband } \\
\hline TS-112 & mth & $\mathrm{P}$ & 52.77 & 1.18 & 17.82 & 8.21 & 0.14 & 6.20 & 8.66 & 3.69 & 0.67 & 0.25 & -0.25 & 99.47 \\
\hline TS-125 & mth & $\mathrm{P}$ & 55.87 & 0.95 & 17.72 & 7.04 & 0.12 & 5.09 & 7.75 & 3.59 & 1.14 & 0.33 & 0.51 & 98.94 \\
\hline TS-291 & mth & $\mathrm{P}$ & 55.77 & 0.90 & 18.19 & 6.79 & 0.12 & 4.87 & 8.06 & 3.71 & 0.94 & 0.26 & -0.08 & 99.65 \\
\hline TS-536 & mth & $\mathrm{P}$ & 56.15 & 0.91 & 17.95 & 6.72 & 0.11 & 5.17 & 7.86 & 3.50 & 0.99 & 0.23 & 0.35 & 99.33 \\
\hline TS-550 & mth & $\mathrm{P}$ & 55.41 & 1.05 & 17.53 & 7.43 & 0.14 & 5.14 & 7.60 & 3.71 & 1.22 & 0.37 & 0.39 & 98.86 \\
\hline TS-558 & mth & $\mathrm{P}$ & 56.99 & 0.92 & 15.88 & 6.43 & 0.13 & 5.52 & 8.33 & 3.31 & 1.71 & 0.38 & 0.12 & 99.10 \\
\hline TS-633 & mth & $\mathrm{P}$ & 52.03 & 1.70 & 16.93 & 9.55 & 0.17 & 5.52 & 8.25 & 3.95 & 0.99 & 0.51 & na & 100.41 \\
\hline \multicolumn{15}{|c|}{ Basaltic andesite of Teardrop Pool } \\
\hline TS-47 & $\mathrm{mtp}$ & $\mathrm{SS}$ & 53.82 & 1.33 & 18.08 & 8.65 & 0.14 & 4.56 & 8.13 & 3.97 & 0.67 & 0.25 & 0.70 & 98.64 \\
\hline TS-48 & mtp & SS & 56.13 & 1.28 & 17.31 & 8.02 & 0.14 & 3.90 & 7.24 & 4.26 & 1.04 & 0.26 & $<0.01$ & 99.54 \\
\hline TS-50 & mtp & SS & 55.83 & 1.20 & 17.84 & 7.61 & 0.13 & 4.20 & 7.29 & 4.20 & 0.99 & 0.31 & $<0.01$ & 99.37 \\
\hline TS-587 & mtp & SS & 54.23 & 1.32 & 17.94 & 8.45 & 0.14 & 4.35 & 8.14 & 3.98 & 0.78 & 0.26 & 0.40 & 98.81 \\
\hline \multicolumn{15}{|c|}{ Basaltic andesite southeast of "Todd Creek" } \\
\hline TS-784 & $\mathrm{mts}$ & $\mathrm{P}$ & 56.10 & 1.27 & 17.32 & 8.37 & 0.15 & 3.60 & 7.04 & 4.47 & 0.99 & 0.29 & na & 99.26 \\
\hline \multicolumn{15}{|c|}{ Basaltic andesite of The Wife } \\
\hline TS-66 & $\mathrm{mtw}$ & $\mathrm{P}$ & 53.03 & 1.09 & 18.28 & 7.81 & 0.13 & 5.87 & 8.76 & 3.53 & 0.77 & 0.33 & 0.06 & 99.72 \\
\hline TS-109 & $\mathrm{mtw}$ & $\mathrm{P}$ & 52.96 & 1.19 & 17.89 & 8.15 & 0.14 & 5.86 & 8.63 & 3.56 & 0.86 & 0.36 & 0.02 & 99.11 \\
\hline TS-128 & $\mathrm{mtw}$ & $\mathrm{P}$ & 52.42 & 1.21 & 18.04 & 8.22 & 0.14 & 6.12 & 8.85 & 3.49 & 0.77 & 0.34 & 0.24 & 98.81 \\
\hline TS-129 & $\mathrm{mtw}$ & $\mathrm{P}$ & 52.08 & 1.24 & 17.86 & 8.37 & 0.14 & 6.32 & 9.00 & 3.48 & 0.75 & 0.34 & 0.04 & 99.25 \\
\hline TS-147 & $\mathrm{mtw}$ & $\mathrm{P}$ & 53.59 & 1.07 & 18.20 & 7.60 & 0.13 & 5.46 & 8.83 & 3.53 & 0.92 & 0.28 & 0.34 & 99.06 \\
\hline TS-148 & $\mathrm{mtw}$ & $\mathrm{P}$ & 52.82 & 1.10 & 18.21 & 7.90 & 0.13 & 6.06 & 8.84 & 3.44 & 0.79 & 0.30 & 0.09 & 99.56 \\
\hline$\underline{\text { TS-149 }}$ & $\mathrm{mtw}$ & $\mathrm{P}$ & 53.46 & 1.09 & 18.35 & 7.89 & 0.13 & 5.55 & 8.43 & 3.63 & 0.75 & 0.31 & 0.19 & 99.31 \\
\hline \multicolumn{15}{|c|}{ Basaltic andesite west of upper Alder Creek } \\
\hline TS-756 & mwa & NS & 53.25 & 1.14 & 19.99 & 7.46 & 0.13 & 4.13 & 8.60 & 3.99 & 0.69 & 0.22 & na & 99.03 \\
\hline TS-759 & mwa & NS & 53.60 & 1.38 & 18.34 & 7.70 & 0.14 & 4.59 & 8.85 & 3.83 & 0.86 & 0.30 & na & 98.00 \\
\hline TS-760 & mwa & NS & 54.96 & 1.54 & 17.70 & 8.71 & 0.15 & 3.51 & 7.31 & 4.61 & 0.84 & 0.27 & na & 99.34 \\
\hline TS-763 & mwa & NS & 55.42 & 1.29 & 18.43 & 7.88 & 0.14 & 3.67 & 6.92 & 4.63 & 0.91 & 0.32 & na & 99.90 \\
\hline TS-765 & mwa & NS & 54.21 & 1.18 & 19.21 & 7.32 & 0.13 & 3.95 & 8.60 & 4.05 & 0.73 & 0.22 & na & 100.06 \\
\hline TS-766 & mwa & NS & 56.12 & 1.24 & 18.37 & 7.60 & 0.14 & 3.36 & 6.72 & 4.76 & 0.96 & 0.33 & na & 100.26 \\
\hline \multicolumn{15}{|c|}{ Basaltic andesite of Whychus Creek } \\
\hline TS-252 & mwh & $\mathrm{P}$ & 53.16 & 1.52 & 18.72 & 8.79 & 0.14 & 3.57 & 8.61 & 4.02 & 0.73 & 0.32 & -0.12 & 99.48 \\
\hline TS-438 & mwh & $\mathrm{P}$ & 54.89 & 1.64 & 17.13 & 9.66 & 0.16 & 3.40 & 7.26 & 4.20 & 0.92 & 0.34 & $<0.01$ & 99.43 \\
\hline TS-449 & mwh & $\mathrm{P}$ & 55.10 & 1.62 & 17.10 & 9.45 & 0.16 & 3.39 & 7.29 & 4.21 & 0.94 & 0.34 & $<0.01$ & 99.61 \\
\hline TS-455 & mwh & $\mathrm{P}$ & 53.38 & 1.63 & 18.33 & 9.24 & 0.15 & 3.55 & 8.26 & 3.92 & 0.78 & 0.37 & 0.09 & 99.45 \\
\hline TS-457 & mwh & $\mathrm{P}$ & 53.73 & 1.65 & 17.91 & 9.37 & 0.16 & 3.54 & 8.05 & 3.98 & 0.83 & 0.38 & $<0.01$ & 99.55 \\
\hline TS-613 & mwh & $\mathrm{P}$ & 55.08 & 1.63 & 17.06 & 9.31 & 0.17 & 3.28 & 7.31 & 4.56 & 0.92 & 0.28 & na & 100.05 \\
\hline TS-616 & mwh & $\mathrm{P}$ & 55.17 & 1.62 & 16.95 & 9.27 & 0.16 & 3.30 & 7.32 & 4.58 & 0.94 & 0.28 & na & 99.86 \\
\hline \multicolumn{15}{|c|}{ Basaltic andesite west of Snow Creek } \\
\hline TS-254 & mws & BT & 54.61 & 1.93 & 16.06 & 10.14 & 0.17 & 3.63 & 7.36 & 4.35 & 0.95 & 0.39 & -0.15 & 99.21 \\
\hline TS-525 & mws & BT & 53.74 & 1.92 & 16.11 & 10.39 & 0.18 & 3.90 & 7.90 & 4.25 & 0.88 & 0.33 & $<0.01$ & 99.53 \\
\hline TS-567 & mws & BT & 53.56 & 1.99 & 16.25 & 10.41 & 0.17 & 3.97 & 7.84 & 4.25 & 0.81 & 0.34 & $<0.01$ & 99.30 \\
\hline TS-669 & mws & BT & 54.97 & 1.89 & 16.17 & 9.60 & 0.17 & 3.54 & 7.34 & 4.55 & 1.02 & 0.36 & na & 99.57 \\
\hline \multicolumn{15}{|c|}{ Basaltic andesite scoria cone west of Yapoah Lake } \\
\hline TS-643 & mwy & NS & 56.44 & 1.58 & 16.95 & 8.48 & 0.15 & 3.31 & 6.47 & 4.71 & 1.17 & 0.34 & na & 98.52 \\
\hline TS-643R & mwy & NS & 56.48 & 1.58 & 16.98 & 8.44 & 0.15 & 3.29 & 6.49 & 4.69 & 1.16 & 0.34 & na & 98.75 \\
\hline TS-645 & mwy & NS & 56.56 & 1.59 & 16.90 & 8.49 & 0.15 & 3.29 & 6.46 & 4.65 & 1.16 & 0.33 & na & 99.75 \\
\hline \multicolumn{15}{|c|}{ Basaltic andesite of Yapoah Lake } \\
\hline TS-597 & myl & NS & 54.16 & 1.10 & 18.29 & 7.51 & 0.13 & 5.34 & 8.25 & 3.76 & 0.80 & 0.25 & na & 100.67 \\
\hline
\end{tabular}




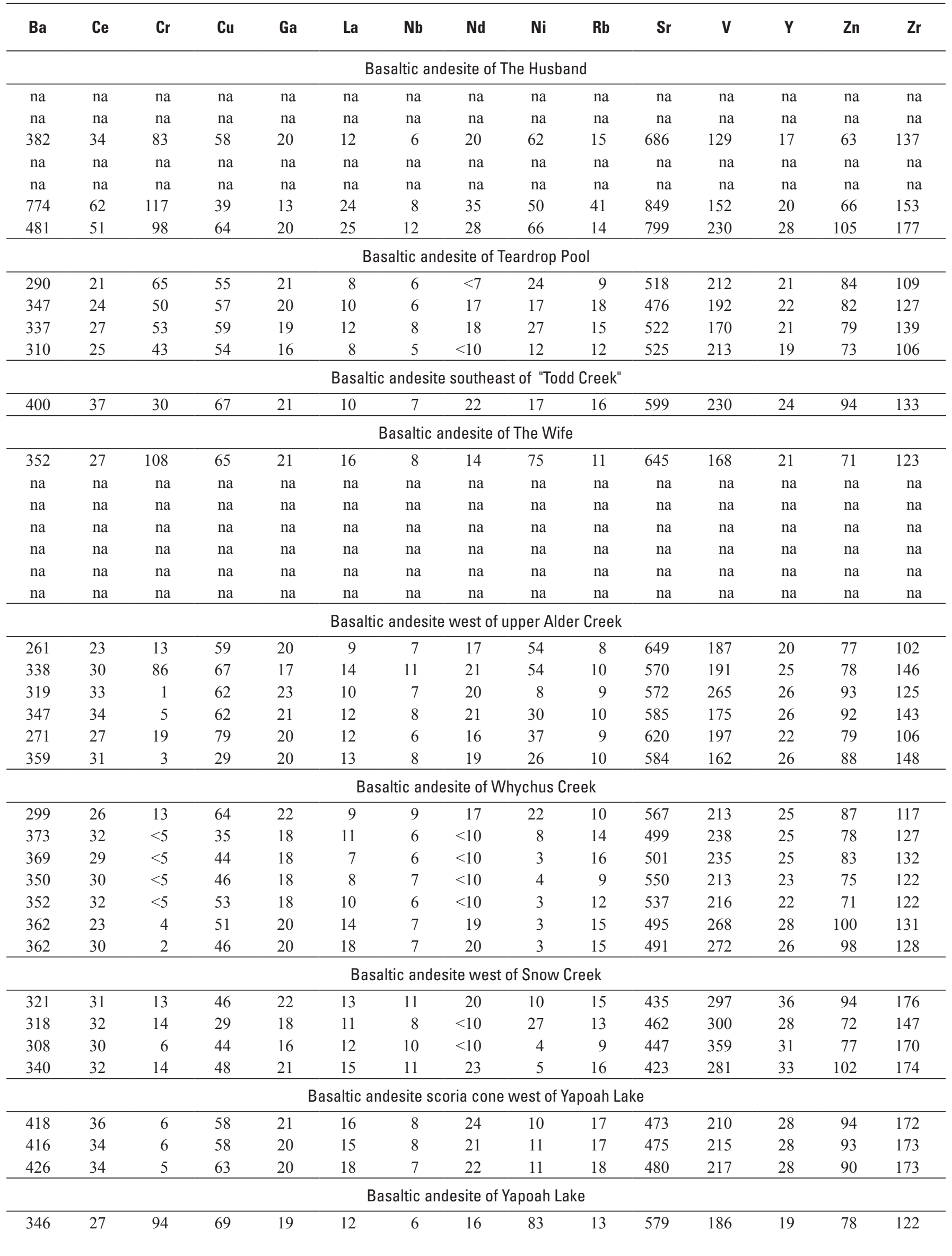


Table 1. Chemical data for Three Sisters volcanic cluster.-Continued

\begin{tabular}{|c|c|c|c|c|c|c|c|c|c|c|c|c|c|c|}
\hline Sample & $\begin{array}{l}\text { Unit } \\
\text { label }\end{array}$ & $\begin{array}{l}\text { Volcanic } \\
\text { group }\end{array}$ & $\mathrm{SiO}_{2}$ & $\mathrm{TiO}_{2}$ & $\mathrm{Al}_{2} \mathrm{O}_{3}$ & $\mathrm{FeO}^{*}$ & MnO & MgO & $\mathrm{CaO}$ & $\mathrm{Na}_{2} \mathrm{O}$ & $\mathrm{K}_{2} \mathrm{O}$ & $\mathbf{P}_{2} \mathbf{O}_{5}$ & LOI & $\begin{array}{c}\text { Original } \\
\text { total }\end{array}$ \\
\hline \multicolumn{15}{|c|}{ Basaltic andesite of Yapoah Lake-Continued } \\
\hline TS-598 & myl & NS & 53.48 & 1.11 & 18.58 & 7.75 & 0.13 & 5.19 & 8.54 & 3.87 & 0.71 & 0.23 & na & 98.54 \\
\hline TS-636 & myl & NS & 53.42 & 1.10 & 18.70 & 7.72 & 0.13 & 5.27 & 8.51 & 3.86 & 0.67 & 0.22 & na & 98.82 \\
\hline TS-650 & myl & NS & 53.62 & 1.09 & 18.68 & 7.66 & 0.13 & 5.20 & 8.44 & 3.86 & 0.69 & 0.22 & na & 98.85 \\
\hline TS-651 & myl & NS & 53.56 & 1.10 & 18.63 & 7.71 & 0.13 & 5.20 & 8.49 & 3.86 & 0.69 & 0.22 & na & 99.04 \\
\hline TS-665 & myl & NS & 53.49 & 1.10 & 18.72 & 7.55 & 0.14 & 5.35 & 8.53 & 3.73 & 0.75 & 0.24 & na & 99.93 \\
\hline TS-666 & myl & NS & 53.65 & 1.11 & 18.68 & 7.58 & 0.13 & 5.12 & 8.54 & 3.86 & 0.71 & 0.23 & na & 100.28 \\
\hline TS-757 & myl & NS & 53.73 & 1.09 & 18.54 & 7.62 & 0.13 & 5.24 & 8.51 & 3.84 & 0.67 & 0.22 & na & 99.51 \\
\hline TS-767 & myl & NS & 53.61 & 1.10 & 18.64 & 7.77 & 0.13 & 5.18 & 8.45 & 3.82 & 0.67 & 0.22 & na & 99.85 \\
\hline NS-07-205 & myl & NS & 53.78 & 1.10 & 18.56 & 7.70 & 0.13 & 5.42 & 8.22 & 3.68 & 0.76 & 0.24 & na & 99.78 \\
\hline \multicolumn{15}{|c|}{ Basaltic andesite southwest of Yapoah Lake } \\
\hline TS-646 & mys & NS & 53.08 & 1.49 & 18.07 & 9.35 & 0.16 & 4.50 & 7.60 & 4.33 & 0.76 & 0.26 & na & 100.70 \\
\hline TS-647 & mys & NS & 52.50 & 1.43 & 17.88 & 9.57 & 0.16 & 5.37 & 7.57 & 4.17 & 0.70 & 0.25 & na & 100.48 \\
\hline TS-647R & mys & NS & 52.49 & 1.42 & 17.86 & 9.56 & 0.16 & 5.37 & 7.60 & 4.18 & 0.70 & 0.25 & na & 100.36 \\
\hline TS-739 & mys & NS & 53.21 & 1.48 & 18.19 & 9.09 & 0.16 & 4.40 & 7.68 & 4.39 & 0.76 & 0.26 & na & 100.00 \\
\hline TS-741 & mys & NS & 53.11 & 1.48 & 18.23 & 9.27 & 0.16 & 4.34 & 7.64 & 4.36 & 0.77 & 0.26 & na & 100.11 \\
\hline TS-776 & mys & NS & 53.13 & 1.47 & 18.06 & 9.19 & 0.15 & 4.60 & 7.66 & 4.33 & 0.74 & 0.26 & na & 99.71 \\
\hline
\end{tabular}

Basaltic andesite window west of Yapoah Lake

\begin{tabular}{|c|c|c|c|c|c|c|c|c|c|c|c|c|c|c|}
\hline TS-644 & myw & NS & 53.04 & 1.03 & 19.21 & 7.25 & 0.13 & 5.37 & 9.07 & 3.69 & 0.63 & 0.19 & na & 100.11 \\
\hline \multicolumn{15}{|c|}{ Rhyolite of South Sister climbers trail } \\
\hline TS-51 & ret & SS & 72.87 & 0.31 & 14.33 & 2.03 & 0.06 & 0.41 & 1.59 & 4.74 & 3.14 & 0.12 & 0.21 & 99.37 \\
\hline TS-52 & ret & SS & 72.94 & 0.30 & 14.29 & 2.00 & 0.05 & 0.40 & 1.60 & 4.75 & 3.15 & 0.13 & 0.36 & 99.00 \\
\hline TS-157 & ret & SS & 72.79 & 0.31 & 14.38 & 1.99 & 0.06 & 0.42 & 1.63 & 4.79 & 3.14 & 0.10 & 0.14 & 99.06 \\
\hline TS-157A & ret & SS & 72.70 & 0.30 & 14.40 & 1.97 & 0.05 & 0.41 & 1.62 & 4.43 & 3.61 & 0.10 & 0.46 & 98.92 \\
\hline TS-164 & ret & SS & 73.05 & 0.30 & 14.27 & 1.98 & 0.06 & 0.40 & 1.63 & 4.67 & 3.15 & 0.09 & 0.44 & 98.45 \\
\hline TS-489 & ret & SS & 73.41 & 0.31 & 14.22 & 2.01 & 0.06 & 0.40 & 1.66 & 4.24 & 3.15 & 0.14 & 0.60 & 100.13 \\
\hline \multicolumn{15}{|c|}{ Rhyolite of "Devils chain" } \\
\hline TS-13 & rdc & SS & 72.46 & 0.33 & 14.31 & 2.13 & 0.05 & 0.58 & 1.91 & 4.52 & 3.17 & 0.13 & 0.24 & 99.52 \\
\hline TS-95 & rdc & SS & 72.43 & 0.34 & 14.41 & 2.12 & 0.05 & 0.57 & 1.93 & 4.45 & 3.14 & 0.16 & 0.46 & 99.56 \\
\hline TS-199 & rdc & SS & 72.56 & 0.34 & 14.35 & 2.14 & 0.05 & 0.56 & 1.94 & 4.40 & 3.16 & 0.10 & 0.50 & 98.55 \\
\hline TS-206 & rdc & SS & 72.57 & 0.34 & 14.31 & 2.16 & 0.06 & 0.56 & 1.93 & 4.40 & 3.16 & 0.10 & 0.61 & 98.82 \\
\hline TS-207 & rdc & SS & 72.63 & 0.33 & 14.32 & 2.14 & 0.05 & 0.55 & 1.94 & 4.37 & 3.16 & 0.10 & 0.82 & 98.73 \\
\hline TS-240 & rdc & SS & 72.61 & 0.34 & 14.36 & 2.13 & 0.05 & 0.53 & 1.95 & 4.36 & 3.15 & 0.11 & 0.35 & 99.17 \\
\hline TS-241 & rdc & SS & 72.55 & 0.33 & 14.31 & 2.14 & 0.05 & 0.59 & 1.93 & 4.40 & 3.17 & 0.11 & 0.53 & 98.84 \\
\hline TS-245 & rdc & SS & 72.57 & 0.34 & 14.35 & 2.16 & 0.05 & 0.57 & 1.95 & 4.36 & 3.14 & 0.10 & 0.74 & 98.54 \\
\hline TS-358 & rdc & SS & 72.63 & 0.33 & 14.27 & 2.08 & 0.05 & 0.54 & 1.95 & 4.53 & 3.14 & 0.08 & na & 99.44 \\
\hline TS-365 & $\mathrm{rdc}$ & SS & 72.65 & 0.33 & 14.19 & 2.12 & 0.05 & 0.53 & 1.92 & 4.50 & 3.19 & 0.12 & 0.32 & 98.98 \\
\hline TS-591 & rdc & SS & 72.54 & 0.34 & 14.31 & 2.13 & 0.05 & 0.52 & 1.94 & 4.44 & 3.14 & 0.18 & 0.35 & 99.54 \\
\hline TS-590 & rdc & SS & 72.49 & 0.34 & 14.34 & 2.14 & 0.06 & 0.52 & 1.96 & 4.46 & 3.12 & 0.18 & 0.24 & 100.03 \\
\hline \multicolumn{15}{|c|}{ Rhyolite of Devils Hill } \\
\hline TS-93 & rdh & SS & 73.35 & 0.28 & 14.21 & 1.86 & 0.05 & 0.38 & 1.49 & 4.66 & 3.17 & 0.14 & 0.46 & 99.53 \\
\hline TS-242 & rdh & SS & 73.66 & 0.27 & 14.05 & 1.85 & 0.05 & 0.37 & 1.48 & 4.62 & 3.18 & 0.08 & 0.51 & 99.25 \\
\hline TS-243 & rdh & SS & 73.69 & 0.28 & 14.04 & 1.84 & 0.05 & 0.36 & 1.46 & 4.63 & 3.17 & 0.08 & 0.13 & 99.35 \\
\hline TS-244 & rdh & SS & 73.67 & 0.27 & 14.03 & 1.85 & 0.05 & 0.37 & 1.46 & 4.63 & 3.18 & 0.08 & 0.25 & 98.70 \\
\hline TS-338 & rdh & SS & 74.05 & 0.26 & 13.85 & 1.73 & 0.05 & 0.30 & 1.40 & 4.58 & 3.24 & 0.14 & 0.40 & 99.26 \\
\hline TS-339 & rdh & $\mathrm{SS}$ & 74.01 & 0.26 & 13.91 & 1.74 & 0.05 & 0.31 & 1.36 & 4.61 & 3.26 & 0.09 & 0.26 & 98.78 \\
\hline
\end{tabular}

\begin{tabular}{lllllllllllllll}
\multicolumn{10}{c}{ Rhyolite of Green Lakes } \\
\hline TS-507 & rgl & SS & 72.92 & 0.33 & 14.46 & 2.09 & 0.06 & 0.44 & 1.73 & 4.31 & 3.11 & 0.15 & 0.79 & 99.85 \\
TS-569 & rgl & SS & 72.18 & 0.33 & 14.54 & 2.12 & 0.06 & 0.47 & 1.73 & 4.72 & 3.38 & 0.09 & 0.41 & 97.98
\end{tabular}




\begin{tabular}{|c|c|c|c|c|c|c|c|c|c|c|c|c|c|c|}
\hline $\mathbf{B a}$ & Ce & $\mathrm{Cr}$ & $\mathrm{Cu}$ & $\mathbf{G a}$ & La & $\mathbf{N b}$ & Nd & $\mathbf{N i}$ & $\mathbf{R b}$ & Sr & $\mathbf{V}$ & $\mathbf{Y}$ & Zn & $\mathrm{Zr}$ \\
\hline \multicolumn{15}{|c|}{ Basaltic andesite of Yapoah Lake-Continued } \\
\hline 303 & 18 & 39 & 72 & 20 & 11 & 5 & 13 & 74 & 10 & 595 & 192 & 19 & 78 & 99 \\
\hline 306 & 22 & 41 & 59 & 18 & 11 & 5 & 15 & 76 & 10 & 593 & 190 & 18 & 78 & 96 \\
\hline 311 & 26 & 39 & 60 & 20 & 11 & 5 & 15 & 74 & 9 & 592 & 183 & 18 & 77 & 100 \\
\hline 309 & 16 & 40 & 71 & 19 & 13 & 5 & 13 & 74 & 10 & 596 & 186 & 18 & 79 & 98 \\
\hline 324 & 28 & 86 & 60 & 19 & 15 & 5 & 15 & 86 & 11 & 588 & 187 & 19 & 82 & 112 \\
\hline 308 & 24 & 41 & 78 & 18 & 10 & 5 & 14 & 77 & 11 & 596 & 187 & 19 & 80 & 102 \\
\hline 301 & 23 & 39 & 71 & 20 & 10 & 6 & 13 & 85 & 10 & 604 & 188 & 20 & 77 & 97 \\
\hline 305 & 25 & 41 & 48 & 19 & 8 & 6 & 15 & 81 & 10 & 603 & 191 & 20 & 79 & 97 \\
\hline 338 & 27 & 95 & 70 & 19 & 12 & 6 & 17 & 84 & 12 & 573 & 176 & 20 & 80 & 121 \\
\hline \multicolumn{15}{|c|}{ Basaltic andesite southwest of Yapoah Lake } \\
\hline 335 & 26 & 3 & 56 & 20 & 14 & 5 & 16 & 42 & 8 & 608 & 232 & 21 & 96 & 102 \\
\hline 312 & 25 & 4 & 39 & 20 & 12 & 5 & 18 & 72 & 7 & 601 & 221 & 20 & 95 & 95 \\
\hline 311 & 25 & 5 & 40 & 19 & 14 & 4 & 17 & 72 & 6 & 602 & 220 & 21 & 94 & 94 \\
\hline 324 & 23 & 3 & 56 & 20 & 11 & 5 & 15 & 42 & 7 & 594 & 227 & 22 & 94 & 102 \\
\hline 335 & 29 & 4 & 63 & 21 & 13 & 5 & 20 & 40 & 8 & 591 & 220 & 22 & 96 & 103 \\
\hline 321 & 27 & 5 & 67 & 20 & 10 & 6 & 17 & 50 & 7 & 607 & 227 & 24 & 95 & 99 \\
\hline
\end{tabular}

Basaltic andesite window west of Yapoah Lake

\begin{tabular}{|c|c|c|c|c|c|c|c|c|c|c|c|c|c|c|}
\hline 267 & 21 & 51 & 79 & 19 & 10 & 4 & 16 & 94 & 6 & 614 & 190 & 18 & 72 & 96 \\
\hline \multicolumn{15}{|c|}{ Rhyolite of South Sister climbers trail } \\
\hline 901 & 45 & 5 & 6 & 18 & 28 & 10 & 24 & 3 & 66 & 188 & 16 & 15 & 35 & 236 \\
\hline 913 & 45 & 6 & 3 & 17 & 30 & 10 & 20 & 3 & 68 & 184 & 17 & 16 & 40 & 237 \\
\hline na & na & na & na & na & na & na & na & na & na & na & na & na & na & na \\
\hline na & na & na & na & na & na & na & na & na & na & na & na & na & na & na \\
\hline 915 & 50 & 7 & 5 & 17 & 29 & 10 & 30 & 5 & 67 & 188 & 19 & 16 & 45 & 238 \\
\hline 977 & 40 & $<5$ & $<2$ & 11 & 20 & 9 & 11 & 2 & 65 & 189 & 6 & 14 & 31 & 233 \\
\hline \multicolumn{15}{|c|}{ Rhyolite of "Devils chain" } \\
\hline 855 & 46 & 5 & 6 & 17 & 33 & 11 & 27 & 4 & 73 & 221 & 21 & 16 & 39 & 194 \\
\hline 847 & 42 & 5 & 7 & 17 & 26 & 10 & 27 & 9 & 75 & 225 & 23 & 16 & 37 & 198 \\
\hline 853 & 44 & 7 & 9 & 17 & 28 & 10 & 23 & 3 & 74 & 226 & 26 & 16 & 40 & 196 \\
\hline 851 & 44 & 6 & 9 & 17 & 28 & 10 & 31 & $<2$ & 73 & 222 & 22 & 16 & 39 & 195 \\
\hline 852 & 45 & 6 & 6 & 17 & 29 & 9 & 29 & 3 & 73 & 221 & 23 & 16 & 39 & 195 \\
\hline 864 & 42 & 8 & 8 & 17 & 27 & 11 & 21 & 8 & 74 & 225 & 21 & 17 & 40 & 196 \\
\hline 861 & 47 & 8 & 9 & 17 & 28 & 10 & 25 & 9 & 74 & 226 & 24 & 17 & 39 & 196 \\
\hline 850 & 45 & 7 & 7 & 17 & 28 & 10 & 25 & 7 & 74 & 225 & 25 & 16 & 38 & 197 \\
\hline 794 & 40 & 3 & 5 & 16 & 23 & 8 & 16 & 0 & 72 & 233 & 20 & 18 & 40 & 181 \\
\hline 852 & 43 & $<5$ & 9 & 19 & 24 & 13 & 26 & na & 79 & 234 & 31 & 22 & 41 & 247 \\
\hline 938 & 36 & $<5$ & $<2$ & 10 & 16 & 9 & 11 & 2 & 71 & 223 & 6 & 15 & 31 & 196 \\
\hline 926 & 37 & $<5$ & $<2$ & 10 & 18 & 8 & 28 & 2 & 68 & 226 & 6 & 14 & 30 & 194 \\
\hline \multicolumn{15}{|c|}{ Rhyolite of Devils Hill } \\
\hline 900 & 51 & 6 & 5 & 16 & 33 & 10 & 18 & 7 & 69 & 174 & 16 & 15 & 42 & 229 \\
\hline 899 & 45 & 7 & 5 & 16 & 28 & 9 & 25 & 6 & 67 & 171 & 16 & 16 & 37 & 225 \\
\hline 912 & 48 & 7 & 6 & 17 & 30 & 10 & 24 & 6 & 68 & 173 & 13 & 15 & 39 & 225 \\
\hline 905 & 43 & 7 & 6 & 16 & 27 & 11 & 17 & 5 & 71 & 172 & 17 & 15 & 40 & 228 \\
\hline 976 & 39 & $<5$ & $<2$ & 10 & 20 & 8 & 14 & 2 & 67 & 156 & 6 & 13 & 29 & 212 \\
\hline 913 & 39 & 7 & 5 & 19 & 25 & 13 & 18 & na & 73 & 164 & 22 & 18 & 38 & 264 \\
\hline \multicolumn{15}{|c|}{ Rhyolite of Green Lakes } \\
\hline 960 & 39 & $<5$ & $<2$ & 12 & 19 & 9 & 19 & 2 & 62 & 191 & 6 & 17 & 34 & 252 \\
\hline 939 & 39 & $<5$ & $<2$ & 11 & 19 & 13 & 14 & 2 & 60 & 193 & 7 & 20 & 27 & 301 \\
\hline
\end{tabular}


Table 1. Chemical data for Three Sisters volcanic cluster--Continued

\begin{tabular}{|c|c|c|c|c|c|c|c|c|c|c|c|c|c|c|}
\hline Sample & $\begin{array}{l}\text { Unit } \\
\text { label }\end{array}$ & $\begin{array}{c}\text { Volcanic } \\
\text { group }\end{array}$ & $\mathrm{SiO}_{2}$ & $\mathrm{TiO}_{2}$ & $\mathrm{Al}_{2} \mathrm{O}_{3}$ & $\mathrm{FeO} *$ & MnO & MgO & $\mathrm{CaO}$ & $\mathrm{Na}_{2} \mathrm{O}$ & $\mathrm{K}_{2} \mathrm{O}$ & $\mathrm{P}_{2} \mathrm{O}_{5}$ & LOI & $\begin{array}{c}\text { Original } \\
\text { total }\end{array}$ \\
\hline \multicolumn{15}{|c|}{ Rhyolite of Kaleetan Butte } \\
\hline TS-73A & rkb & SS & 73.53 & 0.28 & 14.04 & 1.89 & 0.05 & 0.36 & 1.49 & 4.59 & 3.24 & 0.12 & 0.39 & 99.29 \\
\hline TS-94 & rkb & SS & 73.60 & 0.28 & 14.06 & 1.89 & 0.05 & 0.37 & 1.50 & 4.63 & 3.10 & 0.13 & 0.30 & 99.87 \\
\hline TS-138 & rkb & SS & 73.52 & 0.27 & 14.12 & 1.83 & 0.05 & 0.38 & 1.46 & 4.68 & 3.20 & 0.09 & 1.27 & 98.08 \\
\hline \multicolumn{15}{|c|}{ Rhyolite of Mesa Creek } \\
\hline TS-69 & rmc & SS & 72.32 & 0.33 & 14.56 & 2.13 & 0.06 & 0.44 & 1.71 & 4.84 & 3.06 & 0.14 & 0.40 & 99.16 \\
\hline TS-70 & rmc & SS & 72.38 & 0.33 & 14.64 & 2.09 & 0.06 & 0.43 & 1.68 & 4.77 & 3.08 & 0.14 & 0.25 & 99.36 \\
\hline TS-141 & $\mathrm{rmc}$ & SS & 72.59 & 0.32 & 14.46 & 2.05 & 0.06 & 0.43 & 1.67 & 4.80 & 3.10 & 0.10 & 0.91 & 98.51 \\
\hline
\end{tabular}

\begin{tabular}{|c|c|c|c|c|c|c|c|c|c|c|c|c|c|c|}
\hline \multicolumn{15}{|c|}{ Rhyolite of Obsidian Cliffs } \\
\hline TS-102A & roc & MS & 76.54 & 0.11 & 13.04 & 1.00 & 0.04 & 0.15 & 0.86 & 4.34 & 3.42 & 0.11 & 0.38 & 100.07 \\
\hline TS-107 & roc & MS & 76.37 & 0.13 & 13.21 & 1.06 & 0.04 & 0.16 & 0.87 & 4.26 & 3.40 & 0.11 & 0.25 & 100.30 \\
\hline TS-430 & roc & MS & 76.69 & 0.11 & 13.00 & 1.02 & 0.04 & 0.11 & 0.91 & 4.10 & 3.52 & 0.09 & 0.46 & 96.50 \\
\hline
\end{tabular}

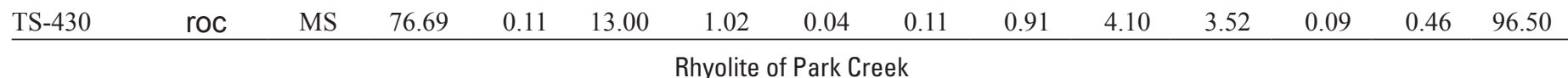

\begin{tabular}{|c|c|c|c|c|c|c|c|c|c|c|c|c|c|c|}
\hline TS-777 & rpc & SS & 72.54 & 0.32 & 14.44 & 2.07 & 0.06 & 0.42 & 1.69 & 4.86 & 3.13 & 0.07 & na & 99.13 \\
\hline EMT-209 & rpc & SS & 72.50 & 0.35 & 14.60 & 2.20 & $<0.1$ & 0.30 & 1.50 & 5.10 & 2.95 & $\sim 0.1$ & na & 99.50 \\
\hline \multicolumn{15}{|c|}{ Rhyodacite of Prouty Glacier } \\
\hline TS-201 & rpg & SS & 68.44 & 0.67 & 15.22 & 3.72 & 0.07 & 1.08 & 3.04 & 4.62 & 2.57 & 0.18 & 0.18 & 98.82 \\
\hline TS-572 & $\mathrm{rpg}$ & SS & 68.11 & 0.65 & 15.17 & 3.85 & 0.08 & 1.35 & 3.16 & 4.66 & 2.43 & 0.14 & 0.25 & 99.15 \\
\hline \multicolumn{15}{|c|}{ Rhyolite of Rock Mesa } \\
\hline TS-65 & rrm & SS & 73.47 & 0.30 & 13.98 & 1.88 & 0.05 & 0.48 & 1.68 & 4.26 & 3.35 & 0.15 & 0.44 & 99.77 \\
\hline TS-159 & $\mathrm{rrm}$ & SS & 73.43 & 0.30 & 14.02 & 1.87 & 0.05 & 0.48 & 1.70 & 4.27 & 3.37 & 0.10 & 0.55 & 98.74 \\
\hline TS- 160 & rrm & SS & 73.53 & 0.29 & 13.94 & 1.85 & 0.05 & 0.47 & 1.70 & 4.27 & 3.39 & 0.10 & 0.65 & 98.62 \\
\hline
\end{tabular}

\begin{tabular}{|c|c|c|c|c|c|c|c|c|c|c|c|c|c|c|}
\hline \multicolumn{15}{|c|}{ Rhyolite of Separation Creek } \\
\hline TS-209 & rsc & SS & 73.85 & 0.26 & 13.87 & 1.76 & 0.05 & 0.48 & 1.51 & 4.40 & 3.36 & 0.07 & 0.41 & 99.13 \\
\hline TS-210 & rsc & SS & 69.63 & 0.49 & 15.15 & 3.05 & 0.07 & 1.07 & 2.60 & 4.71 & 2.69 & 0.14 & 0.14 & 99.27 \\
\hline TS-321 & rsc & SS & 73.33 & 0.29 & 14.04 & 1.89 & 0.05 & 0.53 & 1.60 & 4.53 & 3.26 & 0.07 & 0.30 & 99.28 \\
\hline TS-231 & $\mathrm{rsc}^{\prime}$ & SS & 72.30 & 0.34 & 14.48 & 2.19 & 0.06 & 0.65 & 1.86 & 4.51 & 3.12 & 0.09 & 0.20 & 99.74 \\
\hline \multicolumn{15}{|c|}{ Rhyolite southeast of Lewis Glacier } \\
\hline TS-364 & rse & SS & 73.81 & 0.28 & 13.90 & 1.90 & 0.05 & 0.33 & 1.54 & 4.53 & 3.11 & 0.14 & 0.14 & 99.58 \\
\hline TS-366 & rse & SS & 73.68 & 0.28 & 14.01 & 1.91 & 0.05 & 0.36 & 1.49 & 4.55 & 3.17 & 0.10 & 0.29 & 98.81 \\
\hline TS-486 & rse & SS & 73.98 & 0.30 & 14.04 & 1.95 & 0.05 & 0.35 & 1.56 & 4.10 & 3.13 & 0.15 & 0.16 & 100.04 \\
\hline TS-487 & rse & SS & 73.92 & 0.28 & 14.07 & 1.92 & 0.05 & 0.34 & 1.56 & 4.19 & 3.12 & 0.15 & 0.04 & 99.84 \\
\hline TS-490 & rse & $\mathrm{SS}$ & 73.69 & 0.29 & 14.30 & 1.95 & 0.06 & 0.36 & 1.58 & 4.14 & 3.08 & 0.16 & 0.66 & 99.62 \\
\hline TS-521 & rse & SS & 74.02 & 0.28 & 13.94 & 1.91 & 0.05 & 0.37 & 1.55 & 4.22 & 3.13 & 0.12 & 0.34 & 99.30 \\
\hline TS-522A & rse & $\mathrm{SS}$ & 73.59 & 0.28 & 13.99 & 1.88 & 0.05 & 0.38 & 1.57 & 4.69 & 3.10 & 0.07 & na & 98.45 \\
\hline TS-522B & rse & $\mathrm{SS}$ & 73.64 & 0.28 & 13.98 & 1.89 & 0.05 & 0.37 & 1.54 & 4.68 & 3.10 & 0.06 & na & 99.81 \\
\hline TS-522C & rse & $\mathrm{SS}$ & 73.98 & 0.29 & 13.91 & 1.93 & 0.05 & 0.36 & 1.57 & 4.24 & 3.12 & 0.13 & 0.95 & 98.82 \\
\hline TS-523 & rse & SS & 74.01 & 0.29 & 13.90 & 1.93 & 0.05 & 0.35 & 1.54 & 4.26 & 3.14 & 0.13 & 0.14 & 99.59 \\
\hline \multicolumn{15}{|c|}{ Rhyolite of South Fork Whychus Creek } \\
\hline TS-9 & rsf & $\mathrm{SS}$ & 73.97 & 0.26 & 13.83 & 1.77 & 0.05 & 0.34 & 1.42 & 4.65 & 3.18 & 0.12 & 0.15 & 99.37 \\
\hline TS-15 & rsf & SS & 73.94 & 0.26 & 13.89 & 1.77 & 0.05 & 0.35 & 1.42 & 4.65 & 3.16 & 0.12 & 0.16 & 99.68 \\
\hline TS-16 & rsf & SS & 73.85 & 0.26 & 13.92 & 1.85 & 0.06 & 0.36 & 1.43 & 4.58 & 3.14 & 0.15 & 0.24 & 100.20 \\
\hline TS-17 & rsf & SS & 73.84 & 0.26 & 14.05 & 1.79 & 0.05 & 0.35 & 1.40 & 4.56 & 3.16 & 0.14 & 0.25 & 99.95 \\
\hline TS-18 & rsf & SS & 74.00 & 0.25 & 13.92 & 1.79 & 0.05 & 0.32 & 1.41 & 4.60 & 3.15 & 0.11 & 0.16 & 99.47 \\
\hline TS-166 & rsf & SS & 74.03 & 0.26 & 13.94 & 1.79 & 0.05 & 0.33 & 1.43 & 4.50 & 3.17 & 0.08 & 0.38 & 99.29 \\
\hline TS-167 & rsf & SS & 74.00 & 0.26 & 14.03 & 1.79 & 0.05 & 0.33 & 1.41 & 4.46 & 3.18 & 0.08 & 0.26 & 98.66 \\
\hline TS-168 & rsf & $\mathrm{SS}$ & 74.26 & 0.25 & 13.79 & 1.76 & 0.05 & 0.31 & 1.42 & 4.50 & 3.19 & 0.07 & 0.19 & 98.98 \\
\hline TS-512 & rsf & SS & 74.42 & 0.27 & 13.82 & 1.79 & 0.05 & 0.32 & 1.45 & 4.18 & 3.17 & 0.13 & 0.19 & 99.44 \\
\hline TS-722 & rsf & SS & 73.95 & 0.25 & 14.00 & 1.75 & 0.05 & 0.32 & 1.42 & 4.63 & 3.17 & 0.06 & na & 99.61 \\
\hline
\end{tabular}




\begin{tabular}{|c|c|c|c|c|c|c|c|c|c|c|c|c|c|c|}
\hline $\mathrm{Ba}$ & Ce & $\mathrm{Cr}$ & $\mathrm{Cu}$ & $\mathbf{G a}$ & La & $\mathrm{Nb}$ & Nd & $\mathrm{Ni}$ & $\mathbf{R b}$ & Sr & $\mathbf{V}$ & $\mathbf{Y}$ & $\mathrm{Zn}$ & $\mathrm{Zr}$ \\
\hline \multicolumn{15}{|c|}{ Rhyolite of Kaleetan Butte } \\
\hline 902 & 42 & 4 & 4 & 16 & 28 & 10 & 18 & $<2$ & 67 & 171 & 17 & 16 & 44 & 194 \\
\hline 891 & 47 & 5 & 5 & 17 & 30 & 11 & 30 & 8 & 68 & 174 & 19 & 17 & 41 & 201 \\
\hline na & na & na & na & na & na & na & na & na & na & na & na & na & na & na \\
\hline \multicolumn{15}{|c|}{ Rhyolite of Mesa Creek } \\
\hline 901 & 50 & 6 & 4 & 17 & 29 & 12 & 26 & 3 & 63 & 195 & 17 & 18 & 40 & 253 \\
\hline 909 & 46 & 6 & 7 & 18 & 26 & 10 & 18 & 9 & 62 & 201 & 16 & 17 & 38 & 258 \\
\hline na & na & na & na & na & na & na & na & na & na & na & na & na & na & na \\
\hline \multicolumn{15}{|c|}{ Rhyolite of Obsidian Cliffs } \\
\hline 987 & 46 & 6 & 2 & 15 & 31 & 8 & 12 & 7 & 76 & 104 & 8 & 13 & 33 & 92 \\
\hline 1000 & 59 & 6 & 3 & 15 & 41 & 9 & 51 & 7 & 73 & 107 & 9 & 13 & 31 & 96 \\
\hline 1070 & 33 & $<5$ & $<2$ & 10 & 24 & 8 & 12 & 2 & 75 & 104 & 6 & 13 & 25 & 94 \\
\hline \multicolumn{15}{|c|}{ Rhyolite of Park Creek } \\
\hline 835 & 42 & 2 & 5 & 17 & 22 & 10 & 16 & 2 & 63 & 205 & 15 & 19 & 43 & 251 \\
\hline na & na & na & na & na & na & na & na & na & na & na & na & na & na & na \\
\hline \multicolumn{15}{|c|}{ Rhyodacite of Prouty Glacier } \\
\hline 744 & 38 & 6 & 11 & 18 & 20 & 9 & 26 & 4 & 53 & 287 & 60 & 19 & 48 & 227 \\
\hline 758 & 32 & $<5$ & 10 & 10 & 10 & 10 & 22 & 2 & 46 & 281 & 71 & 20 & 41 & 269 \\
\hline \multicolumn{15}{|c|}{ Rhyolite of Rock Mesa } \\
\hline 888 & 43 & 6 & 7 & 16 & 28 & 10 & 21 & 7 & 80 & 190 & 19 & 16 & 35 & 183 \\
\hline na & na & na & na & na & na & na & na & na & na & na & na & na & na & na \\
\hline na & na & na & na & na & na & na & na & na & na & na & na & na & na & na \\
\hline \multicolumn{15}{|c|}{ Rhyolite of Separation Creek } \\
\hline 846 & 49 & 7 & 10 & 17 & 28 & 9 & 29 & 2 & 74 & 162 & 21 & 15 & 37 & 156 \\
\hline 760 & 47 & 12 & 17 & 18 & 33 & 9 & 38 & 9 & 56 & 261 & 43 & 20 & 44 & 216 \\
\hline 849 & 43 & 9 & 7 & 17 & 28 & 9 & 18 & 4 & 71 & 167 & 23 & 16 & 31 & 157 \\
\hline 832 & 48 & 9 & 12 & 17 & 31 & 9 & 23 & 8 & 66 & 197 & 29 & 17 & 41 & 177 \\
\hline \multicolumn{15}{|c|}{ Rhyolite southeast of Lewis Glacier } \\
\hline 898 & 36 & 6 & 7 & 20 & 25 & 13 & 18 & na & 69 & 184 & 28 & 19 & 39 & 247 \\
\hline 927 & 35 & $<5$ & 9 & 19 & 22 & 12 & 20 & na & 73 & 186 & 32 & 16 & 39 & 250 \\
\hline 981 & 44 & $<5$ & 3 & 12 & 24 & 9 & 22 & 2 & 63 & 177 & 7 & 17 & 30 & 199 \\
\hline 981 & 37 & $<5$ & $<2$ & 11 & 18 & 9 & 10 & 2 & 64 & 176 & 6 & 16 & 31 & 196 \\
\hline 994 & 38 & $<5$ & $<2$ & 11 & 20 & 9 & 15 & 2 & 58 & 181 & 6 & 17 & 34 & 197 \\
\hline na & na & na & na & na & na & na & na & na & na & na & na & na & na & na \\
\hline 815 & 40 & 2 & 5 & 16 & 20 & 9 & 16 & 0 & 66 & 183 & 11 & 18 & 39 & 181 \\
\hline 826 & 37 & 3 & 5 & 16 & 20 & 9 & 15 & 0 & 65 & 183 & 10 & 18 & 38 & 182 \\
\hline na & na & na & na & na & na & na & na & na & na & na & na & na & na & na \\
\hline na & na & na & na & na & na & na & na & na & na & na & na & na & na & na \\
\hline \multicolumn{15}{|c|}{ Rhyolite of South Fork Whychus Creek } \\
\hline 903 & 42 & 6 & 3 & 16 & 27 & 11 & 29 & 4 & 69 & 165 & 14 & 16 & 40 & 190 \\
\hline 907 & 49 & 7 & 7 & 17 & 32 & 11 & 32 & 4 & 68 & 164 & 14 & 16 & 41 & 189 \\
\hline 901 & 41 & 6 & 5 & 15 & 28 & 10 & 27 & 8 & 67 & 166 & 16 & 16 & 40 & 191 \\
\hline 926 & 44 & 7 & 3 & 17 & 27 & 10 & 21 & 5 & 67 & 164 & 15 & 14 & 38 & 188 \\
\hline 915 & 41 & 6 & 4 & 17 & 27 & 10 & 25 & $<2$ & 66 & 165 & 13 & 16 & 38 & 190 \\
\hline 911 & 45 & 7 & 7 & 17 & 31 & 11 & 33 & 4 & 68 & 167 & 14 & 16 & 38 & 193 \\
\hline 922 & 45 & 6 & 7 & 16 & 32 & 11 & 32 & 3 & 68 & 168 & 18 & 16 & 40 & 193 \\
\hline 908 & 45 & 8 & 7 & 16 & 30 & 10 & 26 & 4 & 70 & 166 & 16 & 16 & 41 & 194 \\
\hline na & na & na & na & na & na & na & na & na & na & na & na & na & na & na \\
\hline 827 & 39 & 1 & 2 & 15 & 21 & 9 & 14 & 0 & 67 & 171 & 9 & 17 & 36 & 177 \\
\hline
\end{tabular}


Table 1. Chemical data for Three Sisters volcanic cluster.-Continued

\begin{tabular}{|c|c|c|c|c|c|c|c|c|c|c|c|c|c|c|}
\hline Sample & $\begin{array}{c}\text { Unit } \\
\text { label }\end{array}$ & $\begin{array}{c}\text { Volcanic } \\
\text { group }\end{array}$ & $\mathrm{SiO}_{2}$ & $\mathrm{TiO}_{2}$ & $\mathrm{Al}_{2} \mathrm{O}_{3}$ & $\mathrm{FeO} *$ & MnO & MgO & $\mathrm{CaO}$ & $\mathrm{Na}_{2} \mathrm{O}$ & $\mathrm{K}_{2} \mathrm{O}$ & $\mathbf{P}_{2} \mathbf{O}_{5}$ & LOI & $\begin{array}{c}\text { Original } \\
\text { total }\end{array}$ \\
\hline \multicolumn{15}{|c|}{ Rhyodacite southwest of Golden Lake } \\
\hline TS-514 & rsg & $\mathrm{BT}$ & 70.07 & 0.64 & 14.90 & 3.19 & 0.09 & 0.60 & 1.86 & 5.47 & 2.58 & 0.19 & 0.13 & 98.93 \\
\hline \multicolumn{15}{|c|}{ Rhyolite southwest of Lewis Glacier } \\
\hline TS-144 & rsw & SS & 73.64 & 0.28 & 13.96 & 1.91 & 0.05 & 0.38 & 1.52 & 4.61 & 3.13 & 0.11 & 0.29 & 99.14 \\
\hline TS-156 & rsw & $\mathrm{SS}$ & 73.30 & 0.29 & 14.11 & 1.98 & 0.05 & 0.43 & 1.59 & 4.62 & 3.13 & 0.10 & 0.55 & 98.11 \\
\hline \multicolumn{15}{|c|}{ Rhyodacite of Upper Chush Falls } \\
\hline TS-91 & ruc & BT & 69.07 & 0.50 & 15.39 & 3.52 & 0.10 & 0.55 & 1.94 & 6.05 & 2.30 & 0.18 & 0.06 & 99.64 \\
\hline TS-499 & ruc & BT & 69.68 & 0.50 & 15.52 & 3.42 & 0.09 & 0.46 & 1.90 & 5.54 & 2.31 & 0.18 & 0.19 & 99.48 \\
\hline TS-624 & ruc & BT & 69.21 & 0.49 & 15.41 & 3.49 & 0.09 & 0.49 & 1.88 & 6.12 & 2.31 & 0.10 & na & 99.44 \\
\hline \multicolumn{15}{|c|}{ Rhyolite of Dome 5803} \\
\hline TS-735 & r58 & $\mathrm{P}$ & 73.96 & 0.20 & 14.21 & 1.64 & 0.05 & 0.29 & 1.44 & 4.67 & 3.08 & 0.06 & na & 99.63 \\
\hline
\end{tabular}




\begin{tabular}{|c|c|c|c|c|c|c|c|c|c|c|c|c|c|c|}
\hline $\mathrm{Ba}$ & Ce & $\mathrm{Cr}$ & $\mathrm{Cu}$ & $\mathbf{G a}$ & La & $\mathrm{Nb}$ & Nd & $\mathbf{N i}$ & $\mathbf{R b}$ & Sr & $\mathbf{V}$ & $\mathbf{Y}$ & $\mathrm{Zn}$ & $\mathrm{Zr}$ \\
\hline \multicolumn{15}{|c|}{ Rhyodacite southwest of Golden Lake } \\
\hline \multicolumn{15}{|c|}{ Rhyolite southwest of Lewis Glacier } \\
\hline na & na & na & na & na & na & na & na & na & na & na & na & na & na & na \\
\hline \multicolumn{15}{|c|}{ Rhyodacite of Upper Chush Falls } \\
\hline 669 & 41 & 5 & 7 & 22 & 22 & 12 & 25 & 10 & 45 & 219 & 18 & 38 & 79 & 271 \\
\hline 729 & 40 & $<5$ & $<2$ & 15 & 18 & 10 & 22 & 2 & 42 & 217 & 7 & 27 & 62 & 265 \\
\hline 639 & 37 & 0 & 4 & 21 & 20 & 10 & 23 & 0 & 43 & 221 & 7 & 35 & 75 & 253 \\
\hline \multicolumn{15}{|c|}{ Rhyolite of Dome 5803} \\
\hline
\end{tabular}


Table 2. $\quad{ }^{40} \mathrm{Ar} /{ }^{39} \mathrm{Ar}$ ages for Three Sisters volcanic cluster.

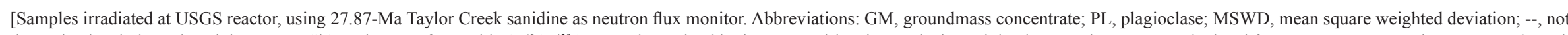

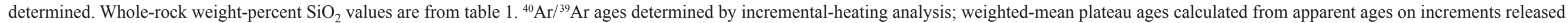
within analytical error; samples without listed plateau ages yielded discordant ${ }^{40} \mathrm{Ar} /{ }^{39} \mathrm{Ar}$ age spectra, but acceptable isochron or total-gas ages. Interpreted eruption ages are highlighted in bold]

\begin{tabular}{|c|c|c|c|c|c|c|c|c|c|c|}
\hline \multirow{2}{*}{ Sample } & \multirow{2}{*}{$\begin{array}{l}\text { Unit } \\
\text { label }\end{array}$} & \multirow{2}{*}{$\begin{array}{c}\text { Whole-rock } \\
\mathrm{SiO}_{2}\end{array}$} & \multirow{2}{*}{ Material } & \multicolumn{2}{|c|}{${ }^{40} \mathrm{Ar} /{ }^{39} \mathrm{Ar}$ weighted-mean plateau age } & \multicolumn{4}{|c|}{${ }^{40} \mathrm{Ar} /{ }^{39} \mathrm{Ar}$ isotope-correlation (isochron) age } & \multirow{2}{*}{$\begin{array}{c}{ }^{40} \mathrm{Ar} /{ }^{39} \mathrm{Ar} \text { total-gas } \\
\text { age (ka) }\end{array}$} \\
\hline & & & & Age (ka) & $\%^{39} \mathrm{Ar}\left[\right.$ steps, $\left.^{\circ} \mathrm{C}\right]$ & Age (ka) & $\%^{39} \mathrm{Ar}\left[\right.$ steps, $\left.{ }^{\circ} \mathrm{C}\right]$ & MSWD & ${ }^{40} \mathrm{Ar} /{ }^{36} \mathrm{Ar}_{\mathrm{i}}$ & \\
\hline TS-324 & $a b t$ & 63.6 & GM & $177.9 \pm 1.1$ & $95[600-1100]$ & $176.9 \pm 2.1$ & $95[600-1100]$ & 0.44 & $296.6 \pm 3.3$ & $176.9 \pm 1.1$ \\
\hline TS-562 & adl & 61.3 & GM & $24.2 \pm 1.1$ & $83[600-800]$ & $29.8 \pm 6.0$ & $83[600-800]$ & 1.48 & $290.4 \pm 12.3$ & $19.9 \pm 1.2$ \\
\hline TS-202 & aeg & 56.5 & GM & $27.0 \pm 3.2$ & $77[650-925]$ & $24.4 \pm 4.8$ & $95[600-1100]$ & 0.79 & $296.9 \pm 2.3$ & $28.5 \pm 3.6$ \\
\hline TS-577 & aeg & 59.2 & GM & $26.7 \pm 1.7$ & $73[600-750]$ & $28.5 \pm 3.6$ & $73[600-750]$ & 2.16 & $295.2 \pm 3.5$ & $27.6 \pm 1.8$ \\
\hline TS-584 & aeg & 56.7 & GM & $28.5 \pm 2.1$ & $77[640-850]$ & $29.0 \pm 6.3$ & $77[640-850]$ & 0.42 & $295.3 \pm 2.7$ & $19.8 \pm 2.7$ \\
\hline TS-44 & ahi & 60.5 & GM & $16.8 \pm 2.1$ & $78[640-940]$ & $23.3 \pm 6.3$ & $78[640-940]$ & 0.62 & $291.5 \pm 2.3$ & $13.1 \pm 2.4$ \\
\hline TS-283 & ahl & 57.9 & GM & $44.5 \pm 3.6$ & $58[550-740]$ & $33.7 \pm 10.5$ & $58[550-740]$ & 0.15 & $298.3 \pm 2.3$ & $20.8 \pm 3.3$ \\
\hline TS-298A & alc & 61.9 & GM & $27.2 \pm 1.0$ & $96[600-1100]$ & $25.5 \pm 1.9$ & $96[600-1100]$ & 1.24 & $297.4 \pm 3.6$ & $27.6 \pm 1.1$ \\
\hline TS-557 & alc & 61.9 & GM & $26.8 \pm 1.2$ & $74[550-750]$ & $30.9 \pm 7.0$ & $74[550-750]$ & 0.91 & $292.0 \pm 12.9$ & $21.9 \pm 1.2$ \\
\hline TS-256 & alg & 62.2 & GM & $27.1 \pm 1.1$ & $100[550-1150]$ & $25.4 \pm 2.2$ & $100[550-1150]$ & 1.02 & $296.5 \pm 2.8$ & $27.6 \pm 1.2$ \\
\hline TS-580 & alh & 62.0 & GM & $30.4 \pm 1.3$ & $89[550-850]$ & $29.5 \pm 5.6$ & $89[550-850]$ & 2.64 & $296.0 \pm 9.4$ & $28.7 \pm 1.3$ \\
\hline TS-472 & anh & 58.0 & GM & $17.9 \pm 2.5$ & $93[550-925]$ & $21.0 \pm 6.3$ & $93[550-925]$ & 1.44 & $294.6 \pm 4.8$ & $15.4 \pm 2.7$ \\
\hline TS-386 & aoc & 58.6 & GM & $47.9 \pm 2.2$ & $67[550-700]$ & $52.0 \pm 11.9$ & $67[550-700]$ & 0.29 & $293.2 \pm 7.9$ & $41.7 \pm 2.3$ \\
\hline TS-426 & aoc & 61.8 & GM & $29.2 \pm 2.3$ & $74[650-830]$ & $48.9 \pm 3.7$ & $74[650-1050]$ & 1.14 & $285.0 \pm 2.9$ & $-75.7 \pm 3.9$ \\
\hline TS-559 & aoc & 60.1 & GM & $44.6 \pm 1.8$ & $74[600-750]$ & $45.2 \pm 12.7$ & $74[600-750]$ & 0.15 & $295.1 \pm 7.5$ & $41.7 \pm 2.0$ \\
\hline TS-622 & apc & 61.6 & GM & $8.4 \pm 3.3$ & $48[650-725]$ & $31.4 \pm 8.7$ & $82[600-850]$ & 0.30 & $290.2 \pm 1.9$ & $2.9 \pm 2.5$ \\
\hline TS-225 & asw & 61.5 & GM & $24.5 \pm 4.2$ & $58[600-800]$ & $36.7 \pm 15.4$ & $58[600-800]$ & 0.38 & $292.6 \pm 3.5$ & $6.6 \pm 4.0$ \\
\hline TS-655 & awa & 57.5 & GM & $25.2 \pm 2.2$ & $83[550-750]$ & $18.1 \pm 8.5$ & $83[550-750]$ & 0.52 & $298.8 \pm 6.6$ & $20.2 \pm 2.1$ \\
\hline TS-372 & awc & 62.1 & GM & $21.9 \pm 1.7$ & $90[600-1250]$ & $24.8 \pm 9.6$ & $90[600-1250]$ & 2.20 & $293.9 \pm 2.0$ & $19.0 \pm 1.7$ \\
\hline TS-392 & awc & 62.1 & GM & $24.5 \pm 1.5$ & $92[600-1100]$ & $27.4 \pm 4.4$ & $92[600-1100]$ & 2.20 & $294.0 \pm 1.8$ & $21.2 \pm 1.7$ \\
\hline TS-510 & awf & 60.0 & GM & $23.7 \pm 1.3$ & $87[600-850]$ & $24.9 \pm 4.0$ & $87[600-850]$ & 0.30 & $294.6 \pm 3.4$ & $23.2 \pm 1.4$ \\
\hline $\mathrm{TS}-453$ & awy & 61.3 & GM & $298.7 \pm 1.4$ & $79[650-830]$ & $292.7 \pm 8.1$ & $79[650-830]$ & 0.46 & $302.5 \pm 14.0$ & $296.9 \pm 1.3$ \\
\hline TS-652A & bac & 53.1 & GM & $127.9 \pm 6.6$ & $73[780-1150]$ & $94.6 \pm 21.5$ & $73[780-1150]$ & 0.80 & $300.7 \pm 7.2$ & $162.2 \pm 11.1$ \\
\hline TS-119 & bjc & 51.6 & GM & $147.9 \pm 4.3$ & $88[650-975]$ & $140.9 \pm 8.6$ & $88[650-975]$ & 1.03 & $297.8 \pm 1.9$ & $151.2 \pm 4.8$ \\
\hline TS-131 & bsb & 51.5 & GM & $278.9 \pm 5.5$ & $88[700-1100]$ & $284.9 \pm 5.4$ & $88[700-1100]$ & 0.31 & $295.2 \pm 1.5$ & $280.2 \pm 6.7$ \\
\hline TS-100 & $\mathrm{dbh}$ & 64.0 & GM & $17.9 \pm 2.2$ & $99[650-1100]$ & $20.1 \pm 6.8$ & $99[650-1100]$ & 1.50 & $294.5 \pm 4.7$ & $12.9 \pm 3.2$ \\
\hline TS-216 & $\mathrm{dbh}$ & 64.4 & GM & $27.1 \pm 1.8$ & $92[550-925]$ & $23.0 \pm 6.8$ & $100[550-1200]$ & 0.32 & $298.2 \pm 3.5$ & $29.0 \pm 2.0$ \\
\hline TS-117 & dcg & 63.3 & GM & $25.9 \pm 1.2$ & $69[650-800]$ & $30.7 \pm 2.6$ & $69[650-800]$ & 0.57 & $290.5 \pm 1.7$ & $11.6 \pm 1.5$ \\
\hline
\end{tabular}


Table 2. $\quad{ }^{40} \mathrm{Ar} /{ }^{39} \mathrm{Ar}$ ages for Three Sisters volcanic cluster.-Continued

\begin{tabular}{|c|c|c|c|c|c|c|c|c|c|c|}
\hline \multirow{2}{*}{ Sample } & \multirow{2}{*}{$\begin{array}{l}\text { Unit } \\
\text { label }\end{array}$} & \multirow{2}{*}{$\begin{array}{c}\text { Whole-rock } \\
\mathrm{SiO}_{2}\end{array}$} & \multirow{2}{*}{ Material } & \multicolumn{2}{|c|}{${ }^{40} \mathrm{Ar} /{ }^{39} \mathrm{Ar}$ weighted-mean plateau age } & \multicolumn{4}{|c|}{${ }^{40} \mathrm{Ar} /{ }^{39} \mathrm{Ar}$ isotope-correlation (isochron) age } & \multirow{2}{*}{$\begin{array}{c}{ }^{40} \mathrm{Ar} /{ }^{39} \mathrm{Ar} \text { total-gas } \\
\text { age (ka) }\end{array}$} \\
\hline & & & & Age (ka) & $\%^{39} \mathrm{Ar}\left[\right.$ steps, $\left.{ }^{\circ} \mathrm{C}\right]$ & Age (ka) & $\%^{39} \mathrm{Ar}\left[\right.$ steps, $\left.{ }^{\circ} \mathrm{C}\right]$ & MSWD & ${ }^{40} \mathrm{Ar} /{ }^{36} \mathrm{Ar}_{\mathrm{i}}$ & \\
\hline TS-19 & dcl & 65.4 & GM & $19.8 \pm 1.6$ & $87[600-850]$ & $26.0 \pm 2.1$ & $100[550-1250]$ & 0.47 & $290.3 \pm 0.9$ & $14.1 \pm 1.7$ \\
\hline TS-115 & ddl & 64.3 & GM & $32.3 \pm 1.8$ & $99[600-1100]$ & $34.1 \pm 2.7$ & $99[600-1100]$ & 1.16 & $294.7 \pm 0.9$ & $31.2 \pm 2.1$ \\
\hline TS-706 & dgc & 65.2 & GM & $31.6 \pm 2.0$ & $100[550-1100]$ & $31.1 \pm 4.4$ & $100[550-1100]$ & 1.15 & $295.8 \pm 7.4$ & $31.3 \pm 2.2$ \\
\hline TS-412 & dhr & 63.6 & GM & $19.1 \pm 1.7$ & $76[630-900]$ & $18.8 \pm 3.8$ & $76[630-900]$ & 0.75 & $295.6 \pm 2.0$ & $14.2 \pm 1.9$ \\
\hline TS-5 & dig & 64.2 & GM & $14.4 \pm 2.7$ & $77[700-1000]$ & $22.9 \pm 11$ & $77[700-1000]$ & 0.91 & $296.6 \pm 8.4$ & $14.7 \pm 2.5$ \\
\hline TSAC1 & $\mathrm{dkb}$ & $\sim 62.5$ & GM & $27.3 \pm 2.6$ & $85[600-950]$ & $26.5 \pm 4.5$ & $85[600-950]$ & 1.99 & $295.8 \pm 2.5$ & $32.1 \pm 2.9$ \\
\hline TS-581 & dlg & 63.6 & GM & $25.3 \pm 1.4$ & $70[620-780]$ & $26.4 \pm 4.4$ & $70[620-780]$ & 3.50 & $291.4 \pm 3.9$ & $18.8 \pm 1.5$ \\
\hline TS-631 & dlg & 63.8 & GM & $22.3 \pm 1.6$ & $78[600-850]$ & $23.2 \pm 5.0$ & $78[600-850]$ & 0.14 & $295.0 \pm 2.3$ & $22.9 \pm 1.5$ \\
\hline TS-103 & dlp & 65.3 & GM & $21.4 \pm 1.9$ & $81[700-1250]$ & $20.4 \pm 7.5$ & $81[700-1250]$ & 2.80 & $294.2 \pm 1.8$ & $19.0 \pm 1.9$ \\
\hline TS-705 & $\mathrm{dml}$ & 64.0 & GM & $33.6 \pm 1.2$ & $79[550-750]$ & $37.5 \pm 6.2$ & $79[550-750]$ & 0.95 & $291.8 \pm 13.3$ & $38.8 \pm 1.4$ \\
\hline TS-492 & dmn & 65.7 & GM & $27.7 \pm 1.0$ & $82[600-1015]$ & $27.8 \pm 2.5$ & $82[600-1015]$ & 1.70 & $294.6 \pm 5.2$ & $19.5 \pm 1.1$ \\
\hline TS-491 & $\mathrm{dmn}$ & 66.1 & GM & $25.2 \pm 0.8$ & $95[590-1000]$ & $27.7 \pm 2.4$ & $95[590-1000]$ & 0.97 & $292.9 \pm 2.3$ & $22.6 \pm 0.9$ \\
\hline TS-629A & dnt & 63.1 & GM & $23.5 \pm 1.1$ & $83[550-850]$ & $27.9 \pm 6.3$ & $83[550-850]$ & 0.39 & $291.3 \pm 7.7$ & $23.9 \pm 1.0$ \\
\hline TS-511 & $\mathrm{drm}$ & 64.3 & GM & $28.7 \pm 0.8$ & $78[700-1250]$ & $28.9 \pm 1.8$ & $78[700-1250]$ & 0.89 & $295.1 \pm 1.6$ & $24.2 \pm 0.9$ \\
\hline TS-257 & dsn & 64.4 & GM & $26.0 \pm 1.5$ & $93[630-1150]$ & $19.1 \pm 3.7$ & $93[630-1150]$ & 0.67 & $299.3 \pm 1.8$ & $26.2 \pm 1.6$ \\
\hline TS-387 & dss & 63.7 & GM & $18.5 \pm 1.5$ & $94[600-1000]$ & $24.5 \pm 3.1$ & $100[550-1150]$ & 1.20 & $292.4 \pm 1.4$ & $17.0 \pm 1.5$ \\
\hline TS-223 & dsw & 65.4 & GM & $28.2 \pm 2.4$ & $77[650-925]$ & $16.8 \pm 15.3$ & $71[650-850]$ & 0.72 & $300.2 \pm 6.2$ & $-3.9 \pm 6.0$ \\
\hline TS-345 & dwp & 64.5 & GM & $25.6 \pm 1.7$ & $72[550-770]$ & $33.6 \pm 3.3$ & $82[550-875]$ & 0.31 & $290.2 \pm 1.7$ & $17.7 \pm 2.0$ \\
\hline TS-22 & $\mathrm{mcl}$ & 56.5 & GM & $16.1 \pm 10.4$ & $73[640-850]$ & $65.9 \pm 14.7$ & $100[550-1250]$ & 8.28 & $291.5 \pm 4.7$ & $-60.9 \pm 13.0$ \\
\hline TS-169 & $\mathrm{mcl}$ & 56.4 & GM & $35.1 \pm 9.0$ & $63[650-1000]$ & $23.3 \pm 15.8$ & $63[650-1000]$ & 0.36 & $297.6 \pm 2.2$ & $31.6 \pm 8.1$ \\
\hline TS-188 & mdl & 53.0 & GM & $205.5 \pm 7.1$ & $79[550-850]$ & $180.8 \pm 20.7$ & $79[550-850]$ & 0.86 & $299.6 \pm 3.3$ & $257.1 \pm 8.1$ \\
\hline TS-178 & mhd & 54.8 & GM & $36.8 \pm 8.9$ & $92[550-925]$ & $44.0 \pm 18.0$ & $92[550-925]$ & 0.52 & $293.8 \pm 3.4$ & $11.3 \pm 11.3$ \\
\hline TS-150 & $\mathrm{mhr}$ & 53.4 & GM & $67.0 \pm 4.1$ & $100[600-1250]$ & $67.3 \pm 1.2$ & $100[600-1250]$ & 0.16 & $295.4 \pm 1.7$ & $59.8 \pm 5.4$ \\
\hline TS-383 & $\mathrm{mlb}$ & 53.1 & GM & $47.2 \pm 5.8$ & $50[700-750]$ & $3.8 \pm 44.2$ & $50[700-750]$ & 0.33 & $302.3 \pm 9.0$ & $29.6 \pm 4.6$ \\
\hline TS-554 & $\mathrm{mlb}$ & 52.6 & GM & $48.4 \pm 3.6$ & $74[550-800]$ & $43.0 \pm 16.8$ & $74[550-800]$ & 0.18 & $296.7 \pm 3.6$ & $34.0 \pm 3.8$ \\
\hline TS-474 & $\mathrm{mmi}$ & 53.3 & GM & -- & -- & $18.1 \pm 3.9$ & $88[550-925]$ & 0.98 & $303.9 \pm 2.5$ & $31.0 \pm 2.1$ \\
\hline TS-429 & $\mathrm{mmm}$ & 56.6 & GM & $19.2 \pm 6.9$ & $50[650-790]$ & $19.6 \pm 5.4$ & $100[550-1075]$ & 1.40 & $293.8 \pm 1.2$ & $9.1 \pm 3.2$ \\
\hline TS-235 & $\mathrm{mms}$ & 53.4 & GM & $16.4 \pm 11.7$ & $83[580-1250]$ & $34.6 \pm 29.5$ & $83[580-1250]$ & 0.96 & $294.2 \pm 1.9$ & $-25.3 \pm 12.3$ \\
\hline TS-444 & $\mathrm{mnf}$ & 54.2 & GM & $47.7 \pm 9.5$ & $99[550-1075]$ & $92 \pm 43$ & $99[550-1075]$ & 1.80 & $291.6 \pm 2.2$ & $39.1 \pm 9.3$ \\
\hline TS-217 & $\mathrm{mnh}$ & 57.1 & GM & $20.9 \pm 5.5$ & $86[550-900]$ & $16.2 \pm 17.2$ & $86[550-900]$ & 0.84 & $296.6 \pm 3.5$ & $17.0 \pm 5.8$ \\
\hline TS-505 & mns & 55.1 & GM & $119.3 \pm 5.6$ & $76[600-900]$ & $136.0 \pm 9.4$ & $100[550-1150]$ & 2.70 & $292.9 \pm 0.8$ & $99.8 \pm 5.5$ \\
\hline
\end{tabular}


Table 2. $\quad{ }^{40} \mathrm{Ar} /{ }^{39} \mathrm{Ar}$ ages for Three Sisters volcanic cluster.-Continued

\begin{tabular}{|c|c|c|c|c|c|c|c|c|c|c|}
\hline \multirow{2}{*}{ Sample } & \multirow{2}{*}{$\begin{array}{l}\text { Unit } \\
\text { label }\end{array}$} & \multirow{2}{*}{$\begin{array}{c}\text { Whole-rock } \\
\mathrm{SiO}_{2}\end{array}$} & \multirow{2}{*}{ Material } & \multicolumn{2}{|c|}{${ }^{40} \mathrm{Ar} /{ }^{39} \mathrm{Ar}$ weighted-mean plateau age } & \multicolumn{4}{|c|}{${ }^{40} \mathrm{Ar} /{ }^{39} \mathrm{Ar}$ isotope-correlation (isochron) age } & \multirow{2}{*}{$\begin{array}{c}{ }^{40} \mathrm{Ar} /{ }^{39} \mathrm{Ar} \text { total-gas } \\
\text { age (ka) }\end{array}$} \\
\hline & & & & Age (ka) & $\%^{39} \mathrm{Ar}\left[\right.$ steps, $\left.{ }^{\circ} \mathrm{C}\right]$ & Age (ka) & $\%^{39} \mathrm{Ar}\left[\right.$ steps, $\left.{ }^{\circ} \mathrm{C}\right]$ & MSWD & ${ }^{40} \mathrm{Ar} /{ }^{36} \mathrm{Ar}_{\mathrm{i}}$ & \\
\hline NS-02-79 & $\mathrm{mns}$ & 53.9 & GM & -- & -- & $83.1 \pm 24.5$ & $100[550-1150]$ & 2.99 & $294.4 \pm 5.6$ & $71.3 \pm 7.0$ \\
\hline NS-02-160 & mns & 54.8 & GM & $70.5 \pm 3.2$ & $80[550-800]$ & $73.7 \pm 15.3$ & $80[550-800]$ & 0.81 & $294.1 \pm 12.8$ & $63.3 \pm 3.6$ \\
\hline NS-02-183 & mns & $\sim 54$ & GM & $55.0 \pm 5.3$ & $60[600-750]$ & $37.6 \pm 47.0$ & $60[600-750]$ & 0.23 & $299.7 \pm 12.6$ & $47.4 \pm 6.1$ \\
\hline TS-388 & mns & 53.8 & GM & $46.2 \pm 5.6$ & $91[600-1250]$ & $52.8 \pm 12.0$ & $100[550-1250]$ & 0.77 & $294.2 \pm 1.3$ & $39.8 \pm 5.2$ \\
\hline TS-670 & $\mathrm{mnt}$ & 55.3 & GM & $20.3 \pm 4.6$ & $79[600-900]$ & $-1.5 \pm 18.4$ & $79[600-900]$ & 0.47 & $299.4 \pm 4.7$ & $4.0 \pm 4.4$ \\
\hline TS-381 & $\mathrm{mrg}$ & 54.6 & GM & -- & -- & $19.6 \pm 6.1$ & $83[650-1060]$ & 1.17 & $289.4 \pm 0.6$ & $-78.9 \pm 6.9$ \\
\hline TS-114 & msc & 56.8 & GM & $17.6 \pm 2.4$ & $100[550-1150]$ & $21.4 \pm 5.5$ & $89[550-975]$ & 0.58 & $294.3 \pm 1.3$ & $17.6 \pm 2.9$ \\
\hline TS-191 & msf & 54.0 & GM & $166.2 \pm 16.0$ & $94[600-1100]$ & $162.6 \pm 43.0$ & $94[600-1100]$ & 0.13 & $295.8 \pm 3.7$ & $158.2 \pm 16.7$ \\
\hline TS-466 & $\mathrm{msp}$ & 54.2 & GM & $116.3 \pm 2.9$ & $96[550-1000]$ & $129.1 \pm 5.8$ & $96[550-1000]$ & 0.57 & $291.8 \pm 1.3$ & $110.2 \pm 3.3$ \\
\hline TS-662 & $\mathrm{mtb}$ & 52.1 & GM & $531.7 \pm 7.3$ & $63[550-725]$ & $539.5 \pm 17.3$ & $63[550-725]$ & 0.62 & $294.1 \pm 5.4$ & $506.3 \pm 7.4$ \\
\hline TS-112 & mth' & 52.8 & GM & $148.9 \pm 4.8$ & $76[600-850]$ & $157.7 \pm 9.6$ & $100[600-1150]$ & 1.44 & $294.3 \pm 1.6$ & $147.1 \pm 6.0$ \\
\hline TS-47 & mtp & 53.8 & GM & $22.3 \pm 12.9$ & $100[550-1150]$ & $18.1 \pm 32.5$ & $100[550-1150]$ & 0.84 & $295.7 \pm 1.6$ & $25.2 \pm 13.2$ \\
\hline TS-147 & mtw & 53.6 & GM & $373.7 \pm 6.0$ & $82[550-850]$ & $361.5 \pm 10.0$ & $82[550-850]$ & 1.30 & $299.6 \pm 6.3$ & $384.7 \pm 6.8$ \\
\hline NS-02-93 & mwa & 54.9 & GM & $58.8 \pm 3.6$ & $63[550-700]$ & $57.1 \pm 18.5$ & $63[550-700]$ & 0.96 & $295.9 \pm 10.4$ & $69.2 \pm 6.0$ \\
\hline TS-252 & mwh & 53.2 & GM & $194.6 \pm 5.0$ & $69[600-750]$ & $206.6 \pm 19.2$ & $69[600-750]$ & 0.63 & $293.2 \pm 6.0$ & $174.5 \pm 7.9$ \\
\hline TS-254 & mws & 54.6 & GM & $174.5 \pm 2.9$ & $80[550-800]$ & $182.0 \pm 12.3$ & $80[550-800]$ & 0.51 & $292.0 \pm 8.5$ & $158.0 \pm 3.5$ \\
\hline TS-51 & ret & 72.9 & PL & $24.0 \pm 5.4$ & $55[900-1050]$ & $29.7 \pm 14.5$ & $55[900-1050]$ & 4.05 & $295.3 \pm 4.1$ & $30.5 \pm 5.3$ \\
\hline TS-157 & ret & 72.8 & PL & $30.4 \pm 7.7$ & $56[900-1075]$ & $69.6 \pm 6.1$ & $100[550-1300]$ & 7.23 & $286.4 \pm 8.2$ & $43.1 \pm 7.0$ \\
\hline TS-339-1 & rdh & 74.0 & GM & $27.2 \pm 1.1$ & $76[550-680]$ & $34.8 \pm 1.5$ & $76[550-680]$ & 0.76 & $285.2 \pm 1.5$ & $8.8 \pm 2.2$ \\
\hline TS-569 & $\mathrm{rgl}$ & 72.2 & GM & $31.9 \pm 0.7$ & $79[600-820]$ & $33.7 \pm 2.6$ & $79[600-820]$ & 1.30 & $292.3 \pm 4.5$ & $26.1 \pm 0.8$ \\
\hline TS-70 & rmc & 72.4 & PL & $47.4 \pm 8.2$ & $88[700-1150]$ & $40.9 \pm 21.0$ & $88[700-1150]$ & 2.09 & $296.7 \pm 2.5$ & $69.6 \pm 9.2$ \\
\hline TS-141 & $\mathrm{rmc}$ & 72.6 & GM & $-39.7 \pm 5.1$ & $76[690-1150]$ & $45.2 \pm 15.0$ & $91[580-975]$ & 1.84 & $288.9 \pm 2.0$ & $-59.1 \pm 5.1$ \\
\hline TS-102 & roc & 76.5 & GM & $37.8 \pm 1.8$ & $59[650-800]$ & $37.6 \pm 17.9$ & $100[500-1200]$ & 5.70 & $295.4 \pm 10.8$ & $38.2 \pm 1.6$ \\
\hline TS-201 & rpg & 68.4 & GM & $32.8 \pm 1.5$ & $88[550-800]$ & $30.6 \pm 2.6$ & $100[550-1200]$ & 0.99 & $297.4 \pm 1.8$ & $34.4 \pm 1.7$ \\
\hline TS-321 & rsc & 73.3 & GM & $25.4 \pm 1.3$ & $91[580-1100]$ & $23.7 \pm 3.6$ & $91[580-1100]$ & 0.28 & $297.1 \pm 3.7$ & $23.9 \pm 1.3$ \\
\hline TS-364 & rse & 73.8 & GM & $31.4 \pm 1.1$ & $53[720-800]$ & $35.0 \pm 2.7$ & $97[600-1150]$ & 2.70 & $286.1 \pm 2.0$ & $5.5 \pm 1.1$ \\
\hline TS-487 & rse & 73.9 & GM & $33.6 \pm 0.5$ & $100[550-1100]$ & $34.0 \pm 1.6$ & $100[550-1100]$ & 0.98 & $295.0 \pm 2.3$ & $33.7 \pm 0.7$ \\
\hline TS-18 & rsf & 74.0 & GM & $35.8 \pm 2.0$ & $76[700-890]$ & $46.5 \pm 6.2$ & $97[600-1020]$ & 1.76 & $282.6 \pm 5.3$ & $33.2 \pm 2.0$ \\
\hline TS-156 & rsw & 73.3 & PL & $50.5 \pm 9.5$ & $77[850-1150]$ & $55.3 \pm 20.7$ & $77[850-1150]$ & 2.21 & $293.7 \pm 11.3$ & $101.8 \pm 9.5$ \\
\hline TS-91 & ruc & 69.1 & GM & $169.3 \pm 2.1$ & $87[600-850]$ & $172.6 \pm 6.0$ & $87[600-850]$ & 1.20 & $295.1 \pm 2.8$ & $167.7 \pm 2.2$ \\
\hline TS-735 & r58 & 74.0 & GM & $40.4 \pm 1.4$ & $93[650-1150]$ & $43.1 \pm 2.9$ & $93[650-1150]$ & 1.02 & $292.9 \pm 5.2$ & $41.1 \pm 1.7$ \\
\hline
\end{tabular}


Table 3. K-Ar ages for Three Sisters volcanic cluster.

[Abbreviations: GM, groundmass concentrate; ${ }^{40} \mathrm{Ar} *$, radiogenic argon; wt.av., weighted average of two K-Ar experiments. Whole-rock weight-percent $\mathrm{SiO}_{2}$ values from table 1; weight percent $\mathrm{K}_{2} \mathrm{O}$ values by flame photometry at U.S. Geological Survey laboratory in Lakewood, Colo., Dave Siems analyst. Interpreted eruption age is highlighted in bold]

\begin{tabular}{|c|c|c|c|c|c|c|c|}
\hline Sample & $\begin{array}{l}\text { Unit } \\
\text { label }\end{array}$ & $\begin{array}{l}\text { Whole-rock } \\
\mathrm{SiO}_{2}\end{array}$ & Material & $\mathrm{K}_{2} \mathrm{O}$ & $\begin{array}{c}{ }^{40} \mathrm{Ar}^{*} \\
\text { (moles/g) }\end{array}$ & $\begin{array}{c}\text { Radiogenic } \\
\operatorname{Ar}(\%)\end{array}$ & $\mathrm{K}-\mathrm{Ar}$ age (ka) \\
\hline TS-100 & $\mathrm{dbh}$ & 64.0 & GM & $1.731 \pm 0.005$ & $6.04 \mathrm{E}-14$ & 1.27 & $24.1 \pm 11.3$ \\
\hline \multirow[t]{3}{*}{ TS-19 } & dcl & 65.4 & GM & $2.339 \pm 0.002$ & $1.08 \mathrm{E}-13$ & 3.01 & $31.9 \pm 8.5$ \\
\hline & & & & & $8.12 \mathrm{E}-14$ & 1.52 & $23.9 \pm 7.3$ \\
\hline & & & & & & (wt.av.) & $27.3 \pm 5.5$ \\
\hline TS-5 & dig & 64.2 & GM & $1.770 \pm 0.000$ & $5.25 \mathrm{E}-14$ & 0.768 & $20.4 \pm 12.2$ \\
\hline TS-94 & rkb & 73.6 & GM & $3.187 \pm 0.055$ & $1.39 \mathrm{E}-13$ & 5.825 & $30.3 \pm 5.3$ \\
\hline TS-18 & rsf & 74.0 & GM & $3.115 \pm 0.003$ & $1.42 \mathrm{E}-13$ & 5.896 & $31.5 \pm 5.1$ \\
\hline TS-91 & ruc & 69.1 & GM & $2.304 \pm 0.006$ & $6.25 \mathrm{E}-13$ & 13.8 & $188.3 \pm 6.7$ \\
\hline
\end{tabular}

